
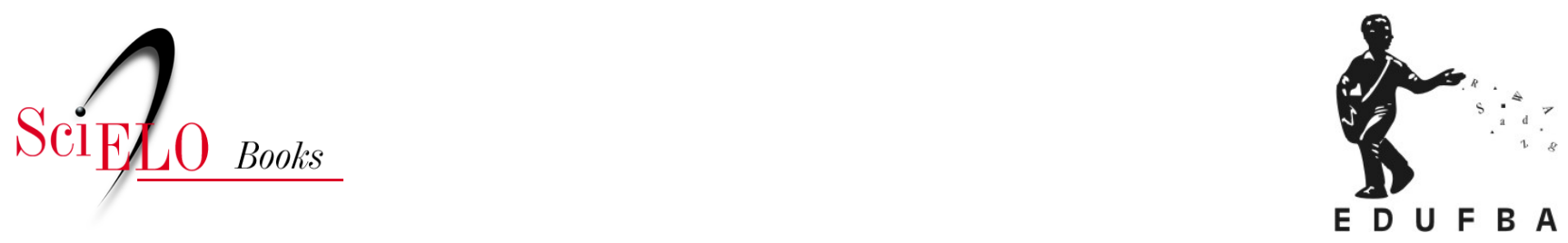

\title{
A construção da igualdade-política e identidade homossexual no Brasil da "abertura"
}

\author{
Edward MacRae
}

\section{SciELO Books / SciELO Livros / SciELO Libros}

MACRAE, E. A construção da igualdade-política e identidade homossexual no Brasil da "abertura" [online]. Salvador: EDUFBA, 2018, 377 p. ISBN 978-85-232-1998-7.

https://doi.org/10.7476/9788523219987.

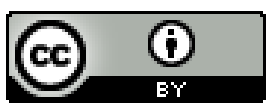

All the contents of this work, except where otherwise noted, is licensed under a Creative Commons Attribution 4.0 International license.

Todo o conteúdo deste trabalho, exceto quando houver ressalva, é publicado sob a licença Creative Commons Atribição 4.0. 


\section{A construção da Igualdade Política e identidade homossexual no Brasil da "abertura"}




\section{UNIVERSIDADE FEDERAL DA BAHIA}

Reitor

João Carlos Salles Pires da Silva

Vice-reitor

Paulo Cesar Miguez de Oliveira

Assessor do Reitor

Paulo Costa Lima



EDITORA DA UNIVERSIDADE FEDERAL DA BAHIA

Diretora

Flávia Goulart Mota Garcia Rosa

Conselho Editorial

Alberto Brum Novaes

Ângelo SzanieckiPerret Serpa

Caiuby Alves da Costa

CharbelNiño El Hani

Cleise Furtado Mendes

Evelina de Carvalho Sá Hoisel

José Teixeira Cavalcante Filho

Maria do Carmo Soares de Freitas

Maria Vidal de Negreiros Camargo 
EDWARD MACRAE

\section{A construção da Igualdade \\ Política e identidade homossexual no Brasil da "abertura"}

Salvador

EDUFBA

2018 
Autores, 2018.

Direitos para esta edição cedidos à Edufba.

Feito o Depósito Legal

Grafia atualizada conforme o Acordo Ortográfico da Língua Portuguesa de 1990, em vigor no Brasil desde 2009.

Ideia original de capa

Sandro Pimentel

Projeto Gráfico

Gabriel Cayres

Revisão

Elber de Oliveira Lima

Normalização

Carina dos Santos

M174 Macrae, Edward.

A construção da igualdade- política e identidade homossexual no Brasil da "abertura". / Edward MacRae. - Salvador: EDUFBA, 2018.

377 p.: il.

ISBN: 978-85-232-1717-4

1. Identidade homossexual. 2. Lésbica. 3.Homossexualidade - aspetos antropológicos. 4.Homossexual - identidade. I. Título.

CDD 306.766

Editora afiliada à

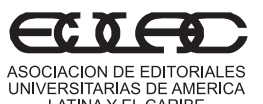
ASOCIACION DE EDITORIALES
UNIVERSITARIAS DE AMERICA
LATINA Y EL CARIBE
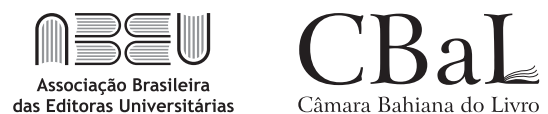

Editora da UFBA

Rua Barão de Jeremoabo

$\mathrm{s} / \mathrm{n}$ - Campus de Ondina

40170-115 - Salvador - Bahia

Tel.: +55 $713283-6164$

Fax: +55 $713283-6160$

www.edufba.ufba.br

edufba@ufba.br 
In memoriam

Meu irmão e grande companheiro Alan Godfrey Gonçalves McRae, meu pai Alan McRae e minha mãe Dulce Baptista das Neves McRae (Dolly), que muito me estimularam e apoiaram, enquanto preparava este trabalho. 


\section{Sumário}

\section{9}

Prefácio da primeira edição de $A$ construção da igualdade Peter Fry

15

Apresentação e agradecimentos

\section{PARTE I - ESCRITOS AVULSOS}

21

Revendo Velhos Escritos

37

Os respeitáveis militantes e as bichas loucas

\section{1}

Em defesa do gueto

67

Afirmação da identidade homossexual:

seus perigos e sua importância

\section{7}

AIDS: prevenção ou novo tipo de segregacionismo?

\section{PARTE II - A CONSTRUÇÃO DA IGUALDADE}

\section{3}

A contestação cultural e a "abertura democrática" 


\section{7}

O antropólogo pode dar voz aos oprimidos sem virar nativo?

\section{9}

Identidade homossexual e política

\section{7}

O jornal "Lampião de esquina"

\section{5}

A fundação do Grupo Somos

\section{9}

O "casamento" com o grupo

\section{5}

As crises do Somos e a defesa do Lampião

\section{9}

Diferenças irreconciliáveis entre os "iguais"

\section{3}

A campanha contra a violência policial

\section{5}

Dupla discriminação e dupla militância, o caso das lésbicas e dos negros dentro do movimento homossexual

\section{1}

A construção da igualdade: movimento, comunidade e identidade

367

Epílogo

371

Referências 


\section{Prefácio da primeira edição de A construção da igualdade}

A beleza está no olhar de quem vê. Da mesma forma, os textos perdem sua objetividade para o olhar histórico de quem os lê. Assim, as etnografias, tantas vezes escritas no "presente etnográfico", serão sempre textos históricos, cujo significado será dado pela perspectiva social, cultural e historicamente distante dos seus leitores.

A leitura deste livro, que trata de eventos que ocorreram há menos de uma década atrás, provoca intensa emoção e uma nostalgia até dolorosa. $\mathrm{O}$ apagar das luzes da ditadura militar coincidia com um otimismo cultural e social bastante generalizado, e os rapazes e moças que fizeram acontecer o movimento homossexual sonhavam com uma sociedade mais justa e igualitária e, sobretudo, uma sociedade em que sua homossexualidade, liberta de todos os tabus, poderia ser celebrada sem restrição. Agora, os tempos são radicalmente outros: vivemos uma conjuntura política e econômica que frustra a todos, e a libertação da homossexualidade está sediada por um vírus misterioso e mortífero.

A história é contada admirável e detalhadamente por Edward MacRae, que, nas melhores tradições da antropologia, se dedicou a combinar os papéis de observador e participante, narrando e vivenciando 
os eventos que descreve e analisa. Com simpatia para com seus amigos e o máximo de objetividade - um ideal, por definição, nunca realizado mas, mesmo assim, guia indispensável para qualquer trabalho sociológico honesto -, Edward MacRae relata os triunfos e desapontamentos, as felicidades e tristezas, e os momentos de união eufórica e cisão amarga do movimento homossexual brasileiro.

Como muitos movimentos de libertação, o movimento homossexual brasileiro esposou um ideal antiautoritário, pressupondo a igualdade de todos seus membros. Este mesmo ideal supõe também uma semelhança fundamental e como que essencial entre os militantes. Na sua análise do nascimento, organização, cisão e relativo desfalecimento do movimento, MacRae mostra como esse ideal esbarrava constantemente contra outros menos explícitos. Os militantes não eram tão iguais assim: uns falavam melhor do que outros, assim dominando as reuniões e influindo mais na tomada de decisão. As mulheres e os negros homossexuais logo se sentiram suficientemente diferentes para formar seus próprios grupos, buscando escapar do machismo e racismo dos outros para poder melhor "trabalhar suas condições específicas". Havia também uma intensa disputa entre aqueles ligados aos partidos políticos e aqueles que acreditavam na necessidade de manter, a todo custo, a autonomia do movimento homossexual. Esta última tensão, especificamente centrada em acusações contra manobras escusas da Convergência Socialista, levou a uma grande e irreparável cisão - o "racha" - no grupo originário do Somos - SP.

Embora centrado no movimento homossexual, o livro tece constantes comparações com outros movimentos sociais da época, sobretudo o movimento feminista, cujas ideias e práticas em muito inspiraram os jovens militantes homossexuais. Assim, creio que o trabalho de Edward MacRae será leitura essencial para todos aqueles que procuram entender melhor o crescimento dos movimentos sociais brasileiros no passado recente e, por conseguinte, sua fase atual.

Uma das coisas que mais me chamou atenção ao ler de novo este livro - fiz parte da banca que examinou uma versão anterior que foi a tese de doutorado do autor - foi uma defasagem bastante grande entre as expectativas dos membros do movimento e a realidade da 
reação pública às reivindicações libertárias. As comemorações do dia primeiro de maio de 1980, programadas pelos metalúrgicos grevistas de São Bernardo do Campo, suscitaram acalorados debates entre os militantes paulistas. Finalmente, uma parte do Somos - aquela que adotava uma posição menos radicalmente autonomista do movimento homossexual - resolveu participar do evento, mas não sem bastante trepidação. Afinal, os sindicatos eram vistos como epicentro do machismo e bastião dos defensores da "luta maior" que privilegiavam a luta de classe e acusavam todos os demais movimentos de serem "diversionistas". Para espanto de todos, porém, os militantes homossexuais foram recebidos com aplausos entusiastas pelos operários. Numa outra ocasião, o pessoal do Somos participou de uma passeata pelo centro de São Paulo, em protesto contra a ação da polícia que perseguia prostitutas e pessoas acusadas de serem homossexuais. Mais uma vez a apreensão. Mais uma vez a ovação. O único caso citado de reprovação concreta foi o de um grampeador lançado da janela de um prédio na rota da passeata.

Com muita razão, o autor considera essa falta de repressão visível ou legal - o Brasil é um caso raro por nunca ter tido nenhuma legislação homofóbica - um dos grandes entraves à organização e à disseminação do movimento homossexual no Brasil. Afinal, nos Estados Unidos havia leis draconianas - ainda há em alguns estados - contra a homossexualidade e, lá, o movimento homossexual teve que enfrentar uma oposição forte e violência. Haja visto o famoso Stonewall Riot, em 1969. Na ausência de um inimigo identificável e tangível, o movimento teve que "inventá-lo", seja ele na Convergência Socialista e nos outros partidos de esquerda - os defensores de "luta maior" -, seja ele dentro do próprio movimento. Correlatas são as cisões e disputas pelo minipoder que o movimento gera. Correlata também - creio eu - é a canalização da energia militante, às vezes, longe do objetivo de eliminar o preconceito contra a homossexualidade para a construção de uma ordem burocrática às alturas da paixão cartorial nacional. Horas e horas são dedicadas à tarefa de esmiuçar a forma que o movimento deve tomar, de definir normas de comportamento nas reuniões, de controlar excessos de autoridade - acusações de "machismo" valem para este movimento o que acusações de "comunista" 
ou reacionário" valem para outros - e de criar fronteiras claras entre homossexuais e heterossexuais.

Esta importante percepção do autor cria ecos em muitos cantos. Penso, de imediato, no movimento negro no Brasil. Ele também enfrenta dificuldades em se organizar, problemas na identificação de um inimigo tangível e uma notável tendência à cisão. A República não produziu legislação explicitamente racista.

Esta constatação suscita velhos fantasmas sobre a constituição e reprodução das desigualdades sociais no Brasil, evocando inevitavelmente surrados argumentos chavões acerca da cordialidade do brasileiro. Mas representa ainda um desafio para quem quer entender uma sociedade que exibe o maior despeito pelas leis que tem - sobretudo quando os ricos as burlam - e uma estranha mas eficiente capacidade de impor leis que não têm. Senão, como explicar a perpetuação das desigualdades raciais? Como entender que as mulheres e homossexuais sentem a necessidade de pôr fim à repressão que sentem?

Estas reflexões são provavelmente parecidas com aquelas feitas pelos próprios militantes. Mas não sei se surtiram o efeito que merecem. Se o movimento negro e o movimento homossexual têm as dificuldades que têm, talvez esteja faltando um conhecimento mais apurado das formas de controle social que caracterizam a sociedade brasileira. As palavras de ordem de ambos os movimentos lembram muito as palavras de ordem dos Estados Unidos e da Europa. E, às vezes, penso que uma das razões de ser destes movimentos é a vontade de compartilhar a modernidade com os países do Primeiro Mundo, seguindo a mesma lógica das modas literárias. Mais um sinal do atrelamento cultural e econômico em geral. Certamente penso e menos cinicamente - que estas palavras de ordem carregam visões sociais que podem distorcer a visão de uma realidade social bastante diversa daquela que as produziu ou, no mínimo, criar a ilusão de que a construção social das diferenças e desigualdades não difere significativamente de um país para outro; de uma cultura para outra.

E não são apenas as formas de controle que variam.

As próprias formas de classificar o que será controlado também divergem, às vezes radicalmente. Para produzir um movimento negro, os seus militantes têm primeiro de convencer muita gente de que o 
Brasil é composto de negros e brancos e não de pretos, sararás, cafuzos, mamelucos, mulatos, etc. Da mesma forma, os militantes homossexuais tiveram que convencer o Brasil de que aqui há homossexuais, bissexuais e heterossexuais, e que esta forma de definir os personagens do cenário sexual amoroso é mais verdadeira do que aquela que tradicionalmente fala de bichas, sapatões, homens, mulheres, viados, giletes, bofes...

Ou seja, o alvo dos movimentos negros e homossexuais não é a "repressão" pura e simples, identificável e tangível; é a cultura brasileira como um todo. Não surpreende tanto, então, suas dificuldades. Por mais que se tente acreditar que transformações sociais podem ocorrer a partir das transformações individuais, o fato é que as estruturas profundas de pensamento social mudam com muito vagar. É seguramente por isso que o movimento homossexual gerou tanta frustração.

Mas, como bem aponta Edward MacRae, o movimento homossexual não foi um fracasso. Tanto assim que membros dele agora participam na luta contra os efeitos sociais mais perversos da aids. Tanto assim que o assunto da discriminação em base da orientação sexual está firmemente colocado na pauta nacional. Se não entrou nesta Constituição, entrará na próxima.

Peter Fry

Rio de Janeiro, 13 janeiro 1989 


\section{Apresentação e agradecimentos}

Este livro é o resultado da pesquisa bibliográfica e de campo, que realizei entre 1978 e 1985, para minha tese de doutorado em antropologia: O militante homossexual no Brasil da "abertura", apresentada em janeiro de 1986 ao Departamento de Ciências Sociais da Faculdade de Filosofia, Letras e Ciências Humanas da Universidade de São Paulo. Foi reescrita para publicação em 1988 e finalmente teve sua primeira edição, pela Editora da Unicamp, em 1990.

Durante esses anos, e, também, enquanto reordenava o material para publicação, contei com a orientação, apoio e amizade de um número muito grande de pessoas, cuja contribuição foi crucial.

É impossível agradecer nominalmente a todos os meus interlocutores, integrantes dos grupos e partidos Somos-SP, GALF, Outra Coisa, Eros, Libertos, Lampião, Somos-RJ, Auê, Grupo Gay da Bahia, Adé Dudu, GATHO, Beijo Livre, Dialogay, Bando de Cá, Coletivo Alegria Alegria, Moléculas Malucas, Terra Maria, Triângulo Rosa, Nós Mulheres, Brasil Mulher, SOS Mulher, Movimento Negro Unificado, PT, PMDB, Convergência Socialista, ao lado de quem tive a oportunidade de discutir a militância política sexual.

O contato com todos esses pontos de vista diferentes e conflitivos, naturalmente resultou num emaranhado de ideias difícil de organizar. A ordem que aparece aqui só pôde surgir graças à cuidadosa orientação 
de meus mestres, Peter Fry e Eunice R. Durham, a quem, além da orientação teórica, devo também muitos dos insights deste trabalho.

Não posso esquecer outros que também me ajudaram a pensar mais teoricamente sobre o assunto lendo trechos de minha tese, dando sugestões ou permitindo-me usar seu próprio material de pesquisa. Agradeço aos professores Luis Mott, Mariza Correa, Verena Stolke, Ruth Cardoso, Oraci Nogueira, Lux Vidal, J. A. Guilhon de Albuquerque, Maria Moraes, Ulisses Ferraz de Oliveira, Júlio Simões, Jorge Beloqui, Pedro Sousa, Matheus Rogatto, Heloísa Pontes, Maria Filomena Gregori, Nestor Perlongher, Vic Seidler, Ernani Pinheiro Chaves, Cláudio P. Coelho, Carmen D. Guimarães, Eduardo Guimarães, Wilson Santos, Richard Parker, Osvaldo Fernandez, Jean Claude Bernardet, Leila Micolis, João Antônio Mascarenhas, Paulo Ottoni, Ricardo C. Pereira, Roseli Roth, Antônio Carlos Tosta, Theodoro Pluciennik, Paulo César Bonfim, Darcy Penteado, João Silvério Trevisan, Glauco Mattoso, Jimmy Green e Severino do Ramo.

Num nível mais informal, mas igualmente importante, devo muito aos meus papos com tantos bons amigos, que têm convivido comigo nestes últimos anos: Ulisses, Ricardo A., Eduardo T., Edson, Marquinhos, Luiz A., Milton, Marcelo, Vilma, Pitú, Teca, Paulo Afonso, Jacira, Mariza, Silas, Zezé, Shuma, Evaristo, Míriam, Hélinho, João Luiz, Luzenário, Ricardo V., Sisi, Israel, Cláudio Motoqueiro, Alexandre, Aroldo, Marivaldo, Wilson D., Amauri, Jerson, Rocha, Juba, Denise, Dilza, Cristiano e Cláudia Wonder.

Um grupo de amigos muito especial foi aquele com quem compartilhei morada nestes últimos anos. Além de dar novas ideias, foram especialmente tolerantes em momentos em que nossa residência foi usada para movimentadas reuniões políticas: Neide Duarte, Anita Jorge, Jussara Amoroso Dias, Júlio Dias Gaspar, Silvana Issa Afram, Fernando de Almeida, Marcos Rogatto e Beto Ronchezel. Nos traumáticos momentos de elaboração de relatório de pesquisa, contei com a companhia de Júlio Assis Simões, para "retiros acadêmicos", altamente produtivos, em Campos de Jordão e Caraguatatuba. Seu conhecimento antropológico e sua biblioteca de ciências sociais, às vezes, me pareciam inesgotáveis.

Durante um período crucial do meu trabalho de campo, fui acometido de hepatite quando pude contar com devotados enfermeiros: meus irmãos Alan e Marina e o amigo Laerth Pedrosa. 
Minhas pesquisas levaram-me também a realizar agradabilíssimas viagens a Salvador, onde o Grupo Gay da Bahia e Luiz Mott puseram à minha disposição os seus riquíssimos arquivos. Também desenvolvi duradouras amizades com Harley Henriques do GAPA-BA, Jerson Matos, Antonio Rocha e Amauri. Nessas, como em outras ocasiões, contei com a maravilhosa hospitalidade de Sofia Olszewski, que me ensinou a ver e amar aquela terra.

Reescrevi a tese para publicação enquanto trabalhava como pesquisador do Conselho Nacional de Desenvolvimento Científico e Tecnológico (CNPq) sediado no Instituto de Medicina Social e de Criminologia de São Paulo (IMESC). Lá fui muito ajudado pelo superintendente Carlos Vicari Jr., além de Maria Etelvina Reis de Toledo Barros, a querida Telva, que tem sido uma amiga de toda hora, dentro e fora do IMESC.

Para o complicado trabalho de datilografia do meu manuscrito, contei com a paciência e o bom humor de Naira N. Ciotti e Milton Filippetti Filho e da militante lésbica feminista Alice, laboriosos críticos e revisores.

A pesquisa começada na Unicamp e terminada na Universidade de São Paulo (USP) foi financiada com bolsas da Coordenação de Aperfeiçoamento de Pessoal de Nível Superior (CAPES) e da Fundação de Amparo à Pesquisa do Estado de São Paulo (FAPESP). A tese original foi transformada em livro enquanto eu era bolsista recém-doutor do Conselho Nacional de Desenvolvimento Científico e Tecnológico (CNPq).

Passados vinte e sete anos da edição original do livro, alguns orientandos e outros amigos instaram-me a republicar o material. Argumenta-se que a edição original teve uma pequena tiragem, que há muito se esgotou, e que o texto, o primeiro estudo acadêmico do movimento homossexual no Brasil, continua a ser de interesse de pesquisadores do tema, agora acrescido de significado como registro histórico de um determinado momento. Revendo o material que produzi naqueles anos, decidi adicionar mais três artigos que versavam sobre questões identitárias e políticas enfrentadas pelos homossexuais, militantes ou não, na virada das décadas de 1970 e 1980, durante o período em que se convencionou chamar de "abertura democrática", quando a ditadura civil-militar começava a dar sinais de fadiga. Também achei importante submeter meu texto original a uma rigorosa e necessária copidescagem, usufruindo do maior desembaraço com a língua 
portuguesa, adquirido durante anos de trabalho na Universidade Federal da Bahia, onde me ingressei como professor em 1995.

Neste novo momento, volto a contar com o auxílio de outros amigos que muito me têm ajudado, nesta e em outras tarefas de cunho profissional e pessoal. Lembro aqui de meu assistente de pesquisa e grande amigo Wagner Coutinho Alves, o Joey, que passou muitas horas com a reorganização do material, de Flávia Goulart Mota Garcia Rosa, diretora da Editora da Universidade Federal da Bahia e de Susane Barros, da sua coordenação editorial. Também tenho recebido importante apoio afetivo do meu companheiro Sandro Pimentel, idealizador do projeto original da capa deste livro. Não posso deixar de mencionar também os velhos amigos Ulisses Ferraz de Oliveira e Mauro Monti, assim como meu sobrinho João Leal MacRae e Isaias Santos, que sempre me brindam com suas agradabilíssimas companhias durante minhas idas a São Paulo. Importantes também foram os incentivos de meus amigos James Green, Leandro Colling, Tedson Sousa e Vinícius Alves que, em diferentes momentos, apontaram a continuada relevância, para os tempos atuais, destes textos sobre a identidade, o movimento e a "movimentação" homossexuais.

Meu pai, Alan MacRae, esteve presente na defesa de minha tese e generosamente me premiou com uma longa viagem. Sua orgulhosa reação ao meu sucesso acadêmico foi muito importante para mim. Fizemos a viagem algum tempo depois, na companhia de minha mãe, mas poucos dias após sua volta, quando eu ainda estava fora, veio a falecer repentinamente. Durante aquela viagem tivemos a possibilidade de estabelecer uma definitiva reconciliação, encerrando um período de rusgas, típicas da minha fase de vida de adolescente e de jovem ainda em amadurecimento. Quatro anos depois, meu queridíssimo irmão Alan também partiu, vítima da aids, três dias após minha família ter todas as suas reservas financeiras congeladas pelo sinistro Plano Collor. Minha mãe, Dulce Baptista das Neves Gonçalves MacRae (Dolly), foi meu esteio emocional durante vários anos difíceis que se seguiram. Sua força, inteligência e carinho pareciam inesgotáveis. Afortunadamente, pude contar com sua companhia por mais um bom tempo. Ao partir, por sua vez, em 2011, deixou maravilhosas lembranças para todos que a conheceram e especialmente para mim, meus irmãos, Marina e Alexander, sua nora Claudia, e seu neto, João. 


\section{PARTE I \\ Escritos avulsos}




\section{Revendo velhos escritos}

Mais de 30 anos após defender, na Universidade de São Paulo, em 1985, a minha tese de antropologia O militante homossexual no Brasil da abertura ${ }^{1}$, sobre o Grupo Somos de Afirmação Homossexual, volto a rever o trabalho, pensando em uma nova publicação do material. A primeira ocorreu em 1990, incorporando algumas referências adicionais, basicamente sobre movimentos sociais, então, um tema relativamente novo na antropologia e na sociologia. O livro $A$ construção da igualdade identidade sexual no Brasil da abertura editado pela Editora Unicamp, teve uma tiragem pequena que logo se esgotou, mas exemplares continuaram a circular entre os interessados e posteriormente uma fotocópia foi colocada na internet.

Ao terminar minha tese, meus interesses de pesquisa se transferiram para o tema do uso de drogas, no qual eu detectava uma situação em que certas noções de saúde vinham mescladas com preconceitos e hipocrisia de maneira similar à que eu havia encontrado ao discutir a questão homossexual. Mas, antes mesmo de terminar a tese, minha atenção já havia sido chamada para os perigos apresentados pelo

1 Tese de doutoramento em Antropologia apresentada, em 1985, ao Departamento de Ciências Sociais da Faculdade de Filosofia, Letras e Ciências Humanas da Universidade de São Paulo, sob orientação da Profạ. Eunice Ribeiro Durham.ah 
advento da pandemia de aids que começava a se espalhar pelo globo. Além das ameaças que representava à saúde geral, a aids também parecia colocar em risco muito dos recentes ganhos conquistados em relação ao combate à discriminação contra os homossexuais. Cuba e alguns outros países davam um péssimo exemplo ao resto do mundo, adotando políticas de internação forçada para os doentes de aids ou soropositivos. No Brasil, locais onde a população gay costumava se reunir voltaram a ser alvo de preocupação para as autoridades. Saunas e outros estabelecimentos, onde eram permitidas relações homossexuais fugazes, viviam sob a ameaça de fechamento, como de fato ocorreu nos Estados Unidos. Apesar das brigas pessoais e políticas que haviam cindido o movimento gay, conforme eu demonstrava em minha tese, perante as novas ameaças, muitos dos militantes voltaram a se reunir para monitorar e criticar os órgãos oficiais de saúde e suas políticas. Os resultados de suas atuações foram de grande importância em assegurar uma abordagem respeitosa dos direitos humanos e uma adequada divulgação de modos de prevenção da doença. (LAURINDO-TEODORESCU; TEIXEIRA, 2015)

Em 1986, procurando um lugar onde pudesse realizar pesquisas sobre o uso de drogas, acabei conseguindo a posição de diretor do centro de estudos do Instituto de Medicina Social e de Criminologia de São Paulo (IMESC), uma autarquia da Secretaria de Justiça do Estado. Esse era o único órgão do estado de São Paulo onde se dava atenção ao uso de drogas ilícitas e à sua prevenção. A questão era vista sob o enfoque de séria ameaça à saúde e à segurança da população e qualquer questionamento das disposições da Lei de Entorpecentes, então em vigor, era vista como inadmissível. Mas o agravamento da pandemia no Brasil levou as autoridades a se preocuparem mais com a população usuária de drogas ilícitas, então concebida como uma das principais vias de disseminação do HIV entre a população em geral. Assim, mais uma vez fui instado a encarar a questão da aids, atuando como especialista de um órgão governamental. Minhas atenções acadêmicas e profissionais passaram então a enfocar questões relacionadas à redução de danos no uso de drogas injetáveis e de crack.

Após a promulgação da Lei de Drogas 11343, em 2006, tornou-se mais fácil questionar a legislação em vigor sem a ameaça de ser 
acusado de fazer apologia ao uso e ao crime, delito previsto na legislação anterior. Começou-se então a constituir o movimento antiproibicionista ao qual me juntei, falando e escrevendo cada vez mais sobre a necessidade de se descriminalizar o uso, a produção e o comercio tanto da maconha quanto das outras drogas consideradas ilícitas. Por essas alturas já ocupava os cargos de professor da Universidade Federal da Bahia (UFBA) e de pesquisador associado do Centro de Estudos e Tratamento do Abuso de Drogas (CETAD/UFBA). Fiquei conhecido por minhas atividades no âmbito da redução de danos, do antiproibicionismo e do uso religioso da ayahuasca. Este último tema, além de responder a anseios espirituais meus, também me parecia um ótimo exemplo do uso controlado de uma substância psicoativa cuja molécula era bastante similar à do LSD, assim como seus efeitos farmacológicos.

Durante vários anos pesquisei e militei nessa área, tendo realizado numerosas palestras e escrito vários textos a respeito da redução de danos e da política de drogas. Meu nome tornou-se bastante conhecido entre os pesquisadores desses temas. Apesar disso, registros informáticos mostram que uma parte considerável das referências acadêmicas à minha produção científica continuam a priorizar meus trabalhos iniciais sobre a militância e identidade gay. Essa constatação me levou a revisitar textos antigos que, mesmo após várias décadas, me parecem continuar pertinentes.

Assim, resolvi reedita-los para facilitar seu acesso a uma nova geração, que atualmente se apresenta como especialmente interessada na discussão de identidades de gênero e sua politização. Nesta reedição ampliada, ao lado de outros textos meus da época e sobre a mesma temática, um lugar especial é ocupado pelo livro resultante da minha tese, submetido a uma revisão de cunho estilístico. Não houve, porém, nenhuma tentativa de atualização nas referências bibliográficas, apesar da considerável produção acadêmica sobre o tema ocorrida nos anos decorridos entre a publicação original e a sua reedição. Isso exigiria uma nova pesquisa, o que fugia da minha proposta de simples republicação. Os outros textos necessitaram de menos alterações.

Embora acredite que esses meus escritos da década de 1980 ainda levantem questões pertinentes, não há como ignorar as muitas 
mudanças sociais e culturais ocorridas nesse meio tempo e talvez valha a pena elencar algumas delas, para contextualizar melhor a minha ideia de então.

Talvez a principal mudança tenha ocorrido com o advento da terapia retroviral, com o decorrente declínio do estigma da infecção pelo HIV, que deixava de significar para o paciente uma sentença de morte certa em pouco tempo e adquiria a natureza de uma doença crônica, mas com a qual é possível viver de maneira bastante normal. O comercio voltado para o mercado gay continuou a se mostrar lucrativo e retomou seu ímpeto, promovendo em seu rastro o fortalecimento de novas afirmações identitárias pouco lembradas originalmente, como o das mulheres lésbicas, das travestis e dos/das transexuais, por exemplo. Movimentos e paradas LGBT cresceram e puderam contar com o beneplácito das autoridades que viam neles agentes importantes de prevenção à aids e outras infecções de transmissão sexual, como as hepatites virais. Onde o legislativo se mostrava lento em reconhecer os novos direitos reivindicados, o judiciário avançou, como no caso do reconhecimento oficial das uniões homoafetivas. A estranheza causada por projetos acadêmicos voltados para o estudo de temas relacionados à homossexualidade aos poucos foi se dissipando devido ao surgimento em várias universidades de cursos e linhas de pesquisas voltadas para a diversidade sexual. No novo clima de relativa tolerância, tornou-se comum ver casais do mesmo sexo expressando suas afetuosidades em público e, em metrópoles como São Paulo, Rio de Janeiro e Salvador já se pode ver com frequência dois homens ou duas mulheres de mãos dadas, caminhando pelas ruas. Em certos casos, podem até se beijar em público, da mesma maneira que os casais heterossexuais.

Tais mudanças, juntamente com o final da ditadura civil-militar, configuram uma situação bastante diversa daquela existente quando realizava as minhas pesquisas. No final da década de 1970, quando as iniciei, vivíamos ainda sob o regime ditatorial. Este, apesar de já haver derrotado a luta armada, empreendida por movimentos guerrilheiros no final da década de 1960 e no início da seguinte, estendia o seu enfoque para o campo dos costumes, sob a alegação de proteger os valores tradicionais da família brasileira. O comportamento 
homossexual, assim como a crescente presença de travestis nas ruas, tornou-se alvo de perseguições policiais, conforme relatado no livro Homossexualidades e ditadura, de Green e Quinalha, 2014. Nessa coletânea, o artigo de Cowan (2014) é especialmente interessante ao revelar o embasamento ideológico e legal dessas medidas repressivas.

A derrota frente às forças da ditadura, juntamente com a crise mundial enfrentada pelas agremiações esquerdistas tradicionais com suas ideias e métodos ainda influenciados pelo stalinismo, havia levado ao descrédito as antigas posições políticas baseadas na noção de luta de classes. A propaganda governamental, aliada à rigorosa censura às produções artísticas e jornalísticas, permitiu um deslumbramento popular com o suposto "milagre econômico", em vigência durante um curto prazo de tempo. Assim como ocorreu recentemente durante a campanha pelo impeachment da Presidenta Dilma Roussef, amplos setores conservadores da sociedade apoiavam as forças antidemocráticas e até setores da classe estudantil ocasionalmente ridicularizavam slogans como "Abaixo a ditadura". Conforme se veria durante as discussões internas que levaram ao "racha" do Grupo Somos-SP, mesmo intelectuais de passado fortemente contestatório rechaçavam violentamente qualquer aproximação a grupos voltados para a militância política nos moldes mais clássicos.

Mas isso não significava necessariamente uma acomodação aos valores do sistema vigente. Perante a impossibilidade de se organizar "politicamente", uma nova geração de jovens passou a fazer "contestação cultural", buscando minar a "moral burguesa", na direção do sexo, drogas e rock'n roll . A contestação de costumes, que explodiu nos EUA e em diversos países da Europa no final dos anos 1960, finalmente chegava de maneira importante ao Brasil. Durante a década de 1970, artistas como Caetano Veloso, Gilberto Gil, Chico Buarque de Hollanda, a trupe Dzi Croquettes, a banda Secos e Molhados e o cantor Ney Matogrosso, entre outros, fizeram apresentações que punham em questão os papeis de gênero vigentes e as ordens erigidas em seu torno. O termo androginia se popularizou mesmo entre setores mais conservadores.

O poder subversivo dessas posições parecia ser confirmado pelas medidas repressivas adotadas pelo sistema ditatorial, como as 
frequentes censuras a publicações, peças teatrais ou músicas que ousavam tratar desses temas. Apesar da repressão, um forte espirito de contestação aos costumes se espalhava pela sociedade. Assim, quando, em 1977, o editor da revista americana Gay sunshine, Winston Leyland, veio ao Brasil para contatar escritores e jornalistas brasileiros que escrevessem sobre a cena homossexual no Brasil, sua visita causou grande repercussão.

Serviu também de estopim para que intelectuais gays brasileiros se organizassem para produzir o jornal Lampião da Esquina, originalmente voltado para as chamadas "minorias" formadas pelas feministas, militantes das causas negras e indígenas e, primordialmente para os homossexuais. O jornal, cujo número zero saiu em abril 1978, teve grande sucesso e, graças ao profissionalismo de seus editores, em grande parte experientes jornalistas, conseguiu-se uma ampla distribuição que cobria o país "do Oiapoque ao Chuí", conforme alardeavam seus editoriais. Logo, porém, a ambição de ser um "jornal das minorias" mostrou-se inviável e o Lampião passou a se restringir em grande parte à discussão de questões gays. Nisso teve um papel de grande importância, divulgando por todo o Brasil conceitos e ações antes restritos a pequenos grupos vanguardistas em algumas capitais. Também foi um grande propulsor da visibilidade lésbica, com matérias de capa sobre mulheres homossexuais, um setor até então completamente desconhecido e ignorado, mesmo pelas feministas.

Em decorrência da nova publicização em nível nacional do debate sobre questões relacionadas à homossexualidade, logo se formaram grupos pretendendo fazer militância gay e lésbica. O engajamento na produção do jornal de Peter Fry, meu orientador no curso de mestrado em Antropologia na Unicamp, levou-me a procurar e juntar-me aos militantes que começavam a se organizar em São Paulo sob o nome de Grupo Somos de Afirmação Homossexual. Assim como vários outros integrantes do grupo, logo me encontrei completamente envolvido na militância, participando de eventos públicos onde expúnhamos nossas experiências e anseios enquanto homossexuais. O grande público que afluía a essas palestras nos dava indicação do grau de interesse despertado por discussões sobre sexualidade, apesar da censura e do clima repressivo reinante. 
Outras atividades importantes eram as chamadas "reuniões de identificação" onde os participantes do grupo relatavam aos outros militantes suas histórias, prazeres e frustrações com suas orientações sexuais. No decorrer dessas reuniões ficavam evidentes os diferentes significados que cada um atribuía às suas práticas sexuais, tornando necessárias numerosas reuniões para se construir objetivos comuns. A própria vivência da sexualidade se mostrava bastante diversa e um dos poucos elementos que unia a maioria era a auto identificação como homossexual e, mesmo assim, esta vinha matizada por diferentes termos como: "bicha", "viado", "bofe”, "passivo", "ativo", "entendido", "gay”, etc. Aparecia, assim, uma primeira crise de identidade e para conviver com ela foram adotadas posturas bastante rígidas de exclusão daqueles que se consideravam bissexuais ou que mostravam outras ambiguidades em sua auto identificação sexual. Até os membros do grupo teatral "Oficina", conhecidos por seus corajosos desafios aos padrões sexuais costumeiros, foram rechaçados devido à sua recusa em se classificarem simplesmente como "homossexuais". Suas propostas identitárias mais fluidas eram consideradas como um temor de "se assumirem". Para combater o estigma sentido pela grande maioria, adotou-se como postura política esvaziar o termo "bicha" de suas conotações negativas. Para tanto, todos passaram a usar essa palavra para se autodesignarem. Inicialmente, até as poucas mulheres que participavam do grupo eram assim chamadas pelos homens. Porém, logo reivindicaram o reconhecimento de suas especificidades, constituindo um subgrupo próprio que eventualmente veio a se declarar completamente autônomo dos homens. Os militantes homossexuais masculinos do Somos editavam um jornal artesanal O corpo e as lésbicas do GALF (Grupo de Atuação Lesbico Feminista) produziam outro, inicialmente chamado Chanacomchana, mas posteriormente rebatizado de Outro olhar. Estes eram distribuídos pelos ativistas nas áreas de concentração homossexual da cidade.

As atividades do Somos levavam a um profundo engajamento pessoal dos seus participantes, cujas vidas passaram a girar em torno do grupo. Além de seus aspectos mais claramente políticos, a nova vida militante se apresentava para muitos como primordialmente uma maneira de socializar, para muitos que até então mantinham 
suas vidas sexuais furtivas e isoladas. No grupo, aprendiam sobre o mundo gay, até então grandemente vivido na clandestinidade e marginalidade, mas no qual começavam a proliferar novos pontos de encontro, principalmente bares e boates. Com o Somos aprendiam a revelar sua homossexualidade em público, seja em confrontos pessoais diretos, seja de maneira mais engajada politicamente. Velhas amizades eram trocadas pelos novos companheiros de militância, e muitos agora procuravam, a partir disso, seus novos namorados. Foi um período em que as pessoas se diziam "casadas com o grupo". Mesmo os estabelecimentos do incipiente mercado voltado para os homossexuais eram desprezados e rotulados de "gueto", por uns. Outros simplesmente chamavam atenção para as naturezas diferentes entre o chamado "movimento", com seus interesses políticos e a "movimentação" mais descompromissada e voltada exclusivamente para a diversão e sociabilidade.

Eu também me senti afetado pelo clima contestatório e militante, decidindo tomar o Somos como tema da minha dissertação de mestrado na Unicamp ${ }^{2}$. Minha "observação participante" rapidamente virou uma "participação observante". Isso porque meu engajamento tornou-se, de certa forma, profissional, já que eu recebia uma bolsa de estudos para financiar minha pesquisa. Devido à minha consequente maior disponibilidade de tempo, eu era um dos frequentadores mais assíduos das atividades do grupo, tornando-me, assim, uma das suas lideranças informais. Dessa maneira passei a integrar o rol daqueles conhecidos no grupo como "bichas históricas", termo aplicado tanto aos primeiros integrantes do grupo, quanto aos membros de sua liderança informal.

Nessa época, era muito escassa a literatura sobre a homossexualidade, que não se restringisse a uma visão médica e patologizante. Lembremos que a homossexualidade era ainda tratada oficialmente pela medicina como "desvio e transtorno mental". Não se encontrava

2 Posteriormente, transferi-me para a Universidade de São Paulo (USP) onde terminei minha pesquisa, cujo resultado apresentei como tese de doutorado. Tive então a orientação de Eunice Durham, que me ajudou muito a pensar sobre o Somos enquanto um movimento social, assunto então bastante em voga. Nesse periodo, contei também com grande auxílio de Ruth Cardoso, que introduzia naquele momento os estudos feministas na universidade. 
nada a respeito na antropologia ou sociologia brasileiras, onde o tema era considerado de pouca importância, quando não objeto de escárnio ou zombaria. Naquele momento, é provável que meu interesse acadêmico pelo assunto foi considerado legítimo somente devido ao prestígio acadêmico do meu orientador Peter Fry. O único texto sócio antropológico anterior que se sabia haver sido escrito no Brasil era uma monografia de especialização que havia sido realizada na USP por Barbosa da Silva, sob a orientação de Florestan Fernandes e defendida em 1958. Mas não havia um exemplar na biblioteca da universidade. A única notícia que se tinha a respeito era um resumo publicado sob o nome Homossexualidade masculina em São Paulo, editada em 1959 pela Revista de sociologia da Fundação Escola de Sociologia e Política de São Paulo de Silva, 1959. ${ }^{3}$

Mais uma vez o auxílio de Peter Fry foi fundamental e ele me franqueou o acesso à sua ampla biblioteca, onde havia vários textos em inglês sobre a homossexualidade da perspectiva das ciências sociais. Através de meu orientador, conheci duas dissertações de mestrado em antropologia orientadas por ele, defendidas por Carmem Dora Guimarães, em 1977, sobre um grupo de "entendidos" cariocas de classe média, e Rosemary Lobert, em 1979, sobre a trupe teatral Dzi Croquettes. Também tive acesso a dois textos seus, que mais tarde viriam a ser editados na coletânea de sua autoria chamada Para inglês ver do autor Fry (1982a, 1982b).

Assim meus referenciais teóricos iniciais eram da autoria de Mary McIntosh, Evelyn Hooker, Jeffrey Weeks e Peter Fry, onde se discutia "o papel social do homossexual". Posteriormente travaria contato com o pensamento foucaultiano, principalmente aquele exposto no primeiro volume da sua História da sexualidade.

Em maio 1980, ocorriam graves tensões internas no grupo Somos. De um lado, estavam aqueles que propunham um engajamento mais amplo, junto a setores da classe operária e agremiações de esquerda, visando contribuir para a mudança do regime ditatorial. De outro, estavam aqueles que achavam necessário priorizar as reivindicações

3 Posteriormente este texto foi encontrado e publicado no livro de Green e Trindade (2005). 
relacionadas à opressão sofrida pelos homossexuais e que não estavam dispostos a confiar nos atores políticos ligados à esquerda tradicional, acreditando que todos seriam machistas e homofóbicos. O grupo lésbico GALF, ficou numa posição intermediária.

Conforme relato em minha tese, essas tensões internas levaram a uma divisão do grupo, o "racha", dando início a um doloroso período de acusações e desencontros afetivos e ao enfraquecimento dos dois grupos masculinos formados agora a partir do antigo Somos. Nesse período, começava a vigorar a chamada "abertura democrática" do regime, abrandando a censura e possibilitando o ressurgimento das organizações político-partidárias, assim como o desenvolvimento de atividades comerciais voltadas especificamente para o mercado homossexual. Nesse novo ambiente, o próprio Lampião começava a perder leitores, perante outras publicações de cunho mais comercial, muitas vezes pornográfico. Igualmente, os numerosos grupos de militância homossexual, perdiam sua exclusividade como locais onde a sociabilidade e a "paquera" gay era viável. Bares, boates e saunas surgiam onde era possível se divertir sem as preocupações e compromissos da militância homossexual, que perdia seu antigo prestígio.

Apesar desse refluxo da militância e das relações conflituosas que se estabeleceram no movimento homossexual como um todo, em 13 de junho conseguiu-se arregimentar, na capital paulista, entre quinhentas e mil pessoas, para a primeira manifestação pública de envergadura do movimento. Essa passeata circulou pela zona central da cidade, protestando contra uma campanha policial que, sob o comando do delegado Wilson Richetti, visava limpar a cidade de gays, travestis e prostitutas.

Nesse novo clima político mais tolerante, começaram a sair também publicações, cientificas ou de não ficção, que tratavam da homossexualidade de forma não patologizante, geralmente a partir de um viés sócio antropológico ou literário.

Desse modo, foram publicados os livros Para inglês ver, coletânea de artigos de Peter Fry (1982); Caminhos cruzados outra coleção que trazia dois textos de Fry e um meu, abordando temas relacionados à homossexualidade (1982); “O que é homossexualidade”, de autoria do Peter e minha (1983); um número da revista Novos estudos CEBRAP, 
veiculando a um artigo meu (1983); o livro Devassos no Paraíso de João Silvério Trevisan (1986). Em 1987, surgia a obra seminal de Nestor Perlongher O Negócio do Michê: prostituição viril em São Paulo". No ano de 1986, defendi na Universidade de São Paulo (USP) a minha tese, $O$ militante homossexual no Brasil da "abertura", que posteriormente foi reescrita e editada sob o nome A construção da igualdade: identidade e política no Brasil da "abertura" (1990). A partir de então, rompido o tabu, surgiram vários outros trabalhos sobre o tema.

A manifestação pública contra as atividades repressivas do delegado Richetti não conseguiram reunificar os/as militantes e os vários grupos começaram a se dissolver em todo o país. Uma exceção foi o Grupo Gay da Bahia, fundado pelo antropólogo Luis Mott em Salvador. Este, juntamente com o grupo carioca Triangulo Rosa encabeçou uma importante e vitoriosa campanha contra a classificação patologizante até então adotada pelos médicos. Assim, apesar das desavenças surgidas entre os militantes do Movimento Homossexual, a chamada "movimentação gay", de natureza lúdica e comercial, parecia ganhar cada vez mais espaço e imperava um grande otimismo entre essa parcela da população residente nas grandes cidades, que cada vez mais se mostrava disposta a "sair do armário". Dos Estados Unidos e de alguns países da Europa Ocidental vinham grandes exemplos de liberação sexual, que eram tomados como modelo pelos brasileiros.

Porém outras notícias começaram a chegar, a partir de 1983, dos Estados Unidos e de outros lugares onde havia grandes comunidades homossexuais. Uma doença misteriosa começava a atacar principalmente homens gays, levando-os rapidamente a uma morte dolorosa e ignóbil. Ícones gays do mundo das artes e da moda começaram a morrer em grande quantidade, sem que se entendesse o modo de infecção. A aids, ainda não identificada como tal, rapidamente chegou a São Paulo, matando numerosos militantes gays e frequentadores do chamado "gueto". Logo rotulada de "câncer gay", a doença levou a um rápido retrocesso no progresso emancipatório homossexual e os próprios estabelecimentos comerciais voltados a essa população se sentiram ameaçados. Notícias chegavam a respeito do fechamento de numerosas saunas gays americanas e alguns países, adotavam 
políticas de internação compulsória dos infectados, à maneira dos antigos leprosários ou dos campos de concentração.

Novamente, os antigos militantes deixaram de lado suas desavenças e se organizaram para fazer frente à pandemia, formando grupos como o GAPA-SP, o GAPA-BA, o GAPA-RJ, a ABIA e outras organizações em diversas regiões do país. Tinham o propósito inicial de prestar assistência e solidariedade aos pacientes, mas não abandonavam suas posturas militantes e aguerridas ao cobrar medidas efetivas do governo. Suas atividades foram bastante bem-sucedidas, servindo de importantes propulsoras dos programas nacionais e regionais de atenção à aids, exigindo a construção de serviços dignos e eficazes para a prevenção e tratamento da moléstia. Enfatizavam sobretudo a importância de preservar os direitos dos pacientes e de suas comunidades. Logo ficou clara a importância dessas organizações para uma resposta adequada à situação e as autoridades nacionais e internacionais começaram a encorajar o surgimento de novos grupos homossexuais militantes e a financiar as suas atividades, especialmente aquelas voltadas para a prevenção, conforme nos relatam Teodorescu e Teixeira (2015). Começou então um novo período de crescimento da militância, embora, com o passar do tempo, suas conexões oficiais e o ingresso de novos agentes, mais familiarizados com os meandros da burocracia oficial, tenham levado a uma redução de seu ímpeto contestatório inicial.

Durante o período em que pesquisei e militei junto ao movimento homossexual, fui frequentemente impactado pelas diferenças entre os variados estilos de militância que encontrava. As diferenças tornavam-se especialmente visíveis nas relações com que os militantes gays travavam participantes de agremiações políticas mais voltadas à luta classista. Enquanto estes primavam por suas aparências sérias e comedidas em termos corporais, os membros do Somos frequentemente recorriam à brincadeira e à "fechação". Mas, mesmo entre os membros dos grupos homossexuais, havia aqueles que preferiam uma apresentação sóbria, voltada fundamentalmente a mostrar que o homossexual podia ser tão "normal" quanto os outros. Em alguns casos, os homossexuais masculinos se esforçavam para mostrar que podiam ser tão "homens" quanto os heterossexuais. Mas a eles se 
contrapunham outros que adotavam posturas mais transgressivas ou caricaturais. Aproveitei então de um honroso convite para participar de uma coletânea com eminentes professores, onde publiquei um artigo, sobre os diferentes tipos de militância, que chamei de "Os respeitáveis militantes e as bichas loucas". Relendo atualmente esse texto, editado originalmente em 1982, achei importante resgata-lo aqui. Considero que continua interessante para aqueles que procuram entender o clima reinante entre os que se opunham ao sistema ditatorial então vigente, atuando de diferentes maneiras. Também me parece que seja de interesse para os membros dos crescentes grupos de jovens, como os que hoje se denominam "não binários", que voltam a transgredir, com intenções políticas, os papeis tradicionalmente atribuídos aos dois sexos, através da vestimenta e de outras formas de comportamento.

Um tema que me chamou muito à atenção durante essa época foi a da importância do então chamado "gueto" para a construção de uma identidade homossexual, algo ainda pouco definido e inconstante. A questão era muito discutida entre os militantes, vários dos quais expressavam um certo desprezo pelos frequentadores dos ambientes gays comerciais, a quem chamavam de "bichas desorganizadas". Minha própria experiência me apontava o quanto se aprende a ser homossexual naqueles ambientes e o quanto isso era importante para a autoestima do indivíduo. Novamente, encontrei diversas divisões entre os frequentadores do "gueto", em termos de classe social, idade e estilo, mas era inegável a importância da maneira como lá se punha em questão a "normalidade", afugentando sentimentos de pecado e doença, que viessem assombrar o indivíduo. Sob o incentivo de Flávio Pierucci, publiquei algumas reflexões a respeito da importância desse espaço lúdico na revista Novos estudos CEBRAP em 1983, no artigo "Em defesa do gueto", também incluído aqui.

Outro texto, "Afirmação de identidade homossexual: seus perigos e sua importância", um artigo escrito enquanto ainda preparava minha tese, mas somente publicado em 1987, voltava-se mais especificamente para a discussão da identidade homossexual. Numa época em que ainda não se tinha notícia das contribuições da teoria queer para o debate, embasei minha argumentação nas propostas de Michel 
Foucault. Seguindo seu exemplo, discutia os perigos de uma naturalização da identidade homossexual, porém, sem deixar de lembrar de sua importância tática na conquista de direitos.

O artigo seguinte foi escrito para a revista Temas IMESC-Sociedade, direito e saúde, após completar meu doutorado, quando já me encontrava profundamente envolvido com a luta contra a aids. Devido à pouca compreensão de seus mecanismos de disseminação, a prevenção à moléstia era baseada em certos elementos do senso comum então reinante, com toda a sua carga de preconceitos. Assim, a forma mais óbvia de prevenção parecia ser a total evitação das práticas homossexuais e o isolamento dos infectados. Este último recurso era discutido em vários lugares e, em alguns casos, chegou a ser posto em prática.

Já a prescrição de abstinência sexual ou de monogamia exclusiva, ia contra as práticas costumeiras de grande parte da população homossexual masculina. Para muitos a alternância constante de parceiros era uma parte constitutiva da identidade gay. As propostas de sexo seguro, apresentadas como alternativa, evitavam a ênfase dada à questão de números de parceiros, para priorizar a adoção de técnicas sexuais capazes de diminuir os riscos de contágio. Mas várias condições pareciam impossibilitar esse recurso no Brasil, como a falta de costume dos homossexuais de se prevenirem usando camisinha. Afinal, diferentemente dos heterossexuais, nunca haviam tido de se prevenir contra o risco de gravidez em suas relações e as doenças sexualmente transmissíveis até então conhecidas, que os acometiam frequentemente, eram facilmente superadas com algumas doses de antibiótico. Outro sério empecilho era a relutância de fundo moralista das autoridades sanitárias e dos meios de comunicação, em difundirem orientações de sexo seguro, que alegadamente encorajariam a promiscuidade.

Este texto foi incluído por fornecer uma ideia do clima ameaçador, quando não havia nenhum tratamento mais eficaz para a doença e que era percebido pelos homossexuais como colocando em risco muitas das conquistas obtidas até então.

Atualmente afortunadamente, parece um tanto defasado, até em termos linguísticos. Conseguiu-se evitar os temidos retrocessos de direitos e ocorreu um radical desvelamento público das práticas sexuais em geral, devido à necessidade de discutir as suas minúcias para 
fazer frente à aids de modo mais efetivo. Um exemplo do anacronismo desse texto é o uso que faço do termo "camisa de vênus", que parecia mais sério e respeitável do que a palavra "camisinha", na época ainda considerada de baixo calão. Essa conotação negativa era normalmente atribuída à natureza supostamente nojenta do contraceptivo e somente alguns mais audaciosos opinavam que seria possível realizar campanhas publicitarias que levassem a uma erotização e maior aceitação desse objeto. Minha razão para incluir aqui o artigo é para que possa servir como registro histórico das preocupações do período. Receava-se que detectar pessoas soropositivas somente servisse para criar uma nova classe de párias sociais, num período em que não se poderia oferecer nenhum tipo de tratamento mais resolutivo capaz de afastar a inevitabilidade de morte a curto prazo.

Finalmente, na última se não mais longa secção desta obra, apresento a versão revisada do livro que escrevi a partir de minha tese $A$ construção da igualdade. Esse texto foi submetido a uma cuidadosa releitura de natureza basicamente estilística, mas sem nenhuma alteração fundamental. Talvez a mais importante e reveladora das mudanças ocorridas no campo, desde a escrita da tese e da primeira edição do livro, seja a maneira como inicialmente, em consonância com o linguajar corrente entre os militantes homossexuais, as travestis eram referidas no masculino. Em respeito às sensibilidades atuais desse segmento da população, fiz as necessárias alterações para trata-las no feminino. Outro ponto que atualmente parece afrontar a correção política foi meu uso ocasional do termo "homossexualismo", que encontrei em alguns dos artigos. $\mathrm{Na}$ época era uma expressão de uso corrente, mesmo entre os militantes. Encontrá-lo nesses textos serviu para me lembrar que a conotação patologizante atualmente atribuída ao termo é relativamente recente. Afinal, o sufixo "ismo" nem sempre se refere a doença, como no caso de "socialismo", " empreendedorismo" ou "lesbianismo", por exemplo. Reconheço, porém a importância da discussão sobre essa forma de expressão, pois tem se mostrado uma boa oportunidade de se levantar a questão da "normalidade" dessa orientação sexual. Afinal, o título do livro que Peter Fry e eu publicamos em 1983, O que é a homossexualidade, foi cuidadosamente escolhido para marcar uma nova e positiva maneira de 
encarar essa orientação sexual. Para tanto, nada melhor do que um nome que fugisse do usual.

\section{Referências}

COWAN, B. Homossexualidade, ideologia e "subversão" no regime militar. In: GREEN, J. N.; QUINALHA, R. (Org.). Ditadura e homossexualidades: repressão, resistência e a busca da verdade. São Carlos, SP: EdUFSCar, 2014. p. 27-52.

FRY, P. Da hierarquia à igualdade: a construção da homossexualidade no Brasil. In: FRY, P. Para inglês ver: identidade e política na cultura brasileira. Rio de Janeiro: Zahar, 1982. p. 87-115.

FRY, P. Homossexualidade masculina e cultos afro-brasileiros. In: FRY, P. Para inglês ver: identidade e política na cultura brasileira. Rio de Janeiro: Zahar, 1982. p. 54-86.

GREEN, J.; TRINDADE, R. (Org.). Homossexualismo em São Paulo e outros escritos. São Paulo: Ed. UNESP, 2005.

GREEN, J. N.; QUINALHA, R. (Org.). Ditadura e homossexualidades: repressão, resistência e a busca da verdade. São Carlos, SP: EdUFSCar, 2014.

LAURINDO-TEODORESCU, L. L.; TEIXEIRA, P. R. Histórias da AIDS no Brasil, 1983-2003: as respostas governamentais à epidemia de aids. Brasília, DF: Ministério da Saúde Secretaria de Vigilância em Saúde: Departamento de DST, Aids e hepatites virais, 2015. v. 1

MACRAE, E. O militante homossexual no Brasil da Abertura. 1985. 218 f. Tese (Doutorado em Antropologia) - Departamento de Ciências Sociais, Faculdade de Filosofia, Letras e Ciências Humanas, Universidade de São Paulo, São Paulo, 1985.

MACRAE, E. A construção da igualdade: identidade sexual e política no Brasil da “abertura”. Campinas, SP: Ed. UNICAMP, 1990.

MACRAE, E. Afirmação de identidade homossexual: seus perigos e sua importância. In: TRONCA, Í. A. (Org.). Foucault vivo. Campinas, SP: Pontes, 1987a. p. 81-88.

MACRAE, E. AIDS: prevenção ou nevo tipo de segregacionismo? Tema IMESCSociedade, Direito e Saúde, São Paulo, v. 4, n. 1, p. 73-81, 1987b.

MACRAE, E. Em defesa do gueto. NOVOS ESTUDOS - CEBRAP, São Paulo, v. 2, n. 1, p. 53-60, abr. 1983.

SILVA, J. F. B. da. Aspectos sociológicos do homossexualismo em São Paulo. Sociologia, v. XXI, n. 4, p. 350 - 360, out. 1959. 


\section{Os respeitáveis militantes e as bichas loucas ${ }^{1}$}

Durante alguns meses nos anos de 1980 e 1981, um jornal alternativo editado em São Paulo resolveu, por conta própria, convidar alguns militantes do Movimento Homossexual para formarem uma editoria homossexual, prometendo-lhes um espaço mais ou menos regular na sua publicação. Apesar de não terem uma ideia muito clara sobre o que era o Movimento Homossexual no Brasil, os editores daquele periódico procuravam ser coerentes com o seu princípio de apoio às reivindicações das chamadas "minorias" e estavam dispostos a dar bastante respaldo aos seus novos companheiros.

Obviamente surgiram vários problemas, principalmente devido a diferenças nas escalas de prioridades. $O$ jornal, apesar de pretender ocasionalmente ceder espaço para matérias sobre os homossexuais, não era o Lampião e tinha como um de seus objetivos principais a construção do então recém-criado Partido dos Trabalhadores. Além disso, há indícios que sua direção não era totalmente autônoma,

1 Texto publicado originalmente em EULÁLIO, A. (Org.). Caminhos Cruzados: linguagem, antropologia, ciências naturais. São Paulo: Brasiliense, 1982. p. 99 - 111. Posteriormente, voltou a ser publicado em: COLLING, L. (Org.). Stonewall $40+0$ que no Brasil? Salvador: EDUFBA, 2011. p. 21-35. 
devendo prestar contas a uma organização de inspiração trotskista, com ramificações em várias regiões do país, para a qual o jornal servia como uma espécie de porta-voz. Por outro lado, no seio do Movimento Homossexual, acabava de ocorrer uma série de incidentes extremamente penosos e algo decepcionante. Esses haviam resultado do esfacelamento do Grupo Somos-SP, pelo qual muitos, com maior ou menor razão, culpavam a atuação de integrantes de outra entidade trotskista; a Convergência Socialista que, segundo se afirmava na época, teria tentado "atrelar" o grupo à sua organização. Como consequência, instaurou-se no Movimento Homossexual uma profunda suspeita de qualquer tipo de atividade político-partidária. Os novos responsáveis pela editoria homossexual nem mesmo estavam inscritos no Partido dos Trabalhadores, então em campanha para conseguir o número mínimo de filiados que lhe possibilitasse uma existência legal. Mas, apesar de sua posição herética no jornal, eram convidados a participar de todas as reuniões de pauta, onde suas opiniões eram devidamente ouvidas e discutidas.

Todo esse relato está aqui para caracterizar o inusitado grau de boa vontade estendida ao Movimento Homossexual e para caracterizar as divergências que surgiram, não como resultado de mero preconceito heterossexual, mas das dificuldades tanto a nível tático quanto estratégico de um entrosamento da luta dos homossexuais organizados com a militância socialista.

Durante algumas semanas conseguiu-se estabelecer um modus vivendi razoavelmente satisfatório e chegou-se a publicar artigos questionando os papéis sexuais e até a forma tradicional de militância esquerdista. Por exemplo, uma manchete encimando um artigo de página inteira sobre a atuação política das lésbicas organizadas, proclamava: "Chanacomchana", o primeiro jornal lésbico do Brasil, declara: "Por uma prática de erotizar a subversão".

Porém, as dificuldades ficaram explícitas quando se quis publicar um artigo enviado pelo Grupo Gay da Bahia, a respeito do $1^{\circ}$ Encontro de Homossexuais Organizados do Nordeste. Este artigo, escrito na linguagem comumente usada pelos integrantes do Movimento Homossexual, procurava transmitir não só as reivindicações levantadas, mas também o clima da reunião. A certa altura, eram transcritas as 
palavras de ordem que haviam sido gritadas durante uma pequena passeata promovida pelos participantes do encontro.

Estas eram frequentemente escandalosas ou aparentemente levianas, como se pode ver pelos seguintes exemplos.

\author{
$A u, a u, a u$, é legal ser homossexual. \\ Éte, éte, éte, é gostoso ser gilete. \\ Ado, ado, ado, ser viado não é pecado. \\ $U, u, u$, é gostoso dar o cu. \\ Ona, ona, ona, é legal ser sapatona. \\ O coito anal derruba o capital.
}

Algumas das opiniões dos participantes que foram transcritas pareciam especialmente provocativas às pessoas engajadas em uma militância ortodoxa esquerdista, como a que dizia:

Diversidade não é divisão. É pluralismo, é criatividade. Quanto mais diferente, melhor. Somos pelo show pirotécnico! Pela esculhambação organizada!

Logo de início, ao receberem o artigo, os responsáveis pela editoria homossexual constataram que seria impossível a sua publicação em versão integral devido a problemas de espaço, mas no resumo que fizeram mantiveram algumas das palavras de ordem, como as que diziam que é legal ser homossexual e que é gostoso ser gilete, que consideraram as menos escandalosas. Mesmo assim, os resultados desta autocensura levantaram inúmeras dúvidas entre os outros membros do corpo editorial. Estes, embora dispostos a publicar o artigo por uma questão de democracia interna, não deixaram de dar vários conselhos a respeito da matéria da orientação que estava sendo dada àquela editoria em geral. Alegava-se que a linguagem usada era apropriada a uma publicação voltada a um mercado gay, mas que naquele jornal ela serviria somente para confirmar preconceitos, reforçando a imagem caricatural do homossexual como palhaço e ridículo. Também foi lembrado que alguns leitores já haviam reclamado do espaço excessivo que estaria sendo reservado a essas matérias de importância considerada secundária.

Nesta ocasião, o resumo do artigo acabou sendo publicado, mas provavelmente só porque seu conteúdo tratava de uma importante 
reunião dos grupos homossexuais do Nordeste, caindo, portanto, na categoria de "militância", tão cara à direção do jornal. Tivesse ele uma natureza mais reflexiva, discutindo em mais profundidade a questão homossexual, suas dificuldades de aceitação certamente seriam maiores, se persistisse em empregar tal linguagem. Ficou então colocado para os editores homossexuais, de forma bastante clara, as contradições que defrontavam na sua tentativa de levar a discussão da homossexualidade para um campo dominado por uma concepção de política como relacionada primária e quase exclusivamente à luta de classes. Para serem ouvidos e entendidos, pediam-lhes que higienizassem a homossexualidade, reduzindo seus praticantes à categoria mais facilmente assimilável de "grupo oprimido lutando por seus direitos", conceptualmente não muito diferente de uma associação de favelados talvez lutando pela abertura de uma escola em seu bairro para possibilitar a integração de seus filhos na estrutura social em uma posição mais vantajosa.

Não se deve criticar demasiado o corpo editorial do jornal por isso, pois a atitude que recomendavam foi adotada durante muito tempo pelos próprios batalhadores pelos direitos dos homossexuais. Desde os primórdios daquela campanha, tentou-se mostrar que eles poderiam ser cidadãos tão bons, decentes e integrados quanto os heterossexuais. No século passado chegou-se ao ponto de inventar a ideia de um "terceiro sexo" para o qual a homossexualidade seria "natural", por ser uma tendência congênita. Mas, ao lado desta aristocracia, homossexual por nascimento, haveria um bando desclassificado de parvenus degenerados, os "pervertidos", cuja homossexualidade era "adquirida" e, portanto, ilegítima e passível a todo tipo de repressão.

Os militantes homossexuais de então eram realmente bastante respeitáveis, frequentemente escudando suas reivindicações atrás de títulos médicos e quase invariavelmente procurando angariar as simpatias do establishment. Em seu livro de memorias Christopher and his kind, o romancista inglês Christopher Isherwood descreve o contato que ele teve com Magnus Hirschfeld, provavelmente o mais importante dos primeiros militantes homossexuais. Em 1929, visitando o Instituto de Ciência Sexual, alojado em um belo palácio da antiga Berlim, ele se surpreendeu com o clima de seriedade 
e respeitabilidade do que era então uma espécie de quartel general do movimento homossexual.

O mobiliário era clássico, com pilares e guirlandas, mármores pesados, cortinas solenemente esculturais e gravuras sóbrias. O almoço era uma refeição de decoro e sorrisos graciosos, presidida por uma senhora grisalha de amável dignidade: uma garantia viva de que o sexo naquele santuário era tratado com seriedade. Como não seria? Sobre a entrada do Instituto havia uma inscrição em latim com os dizeres: "Sagrado ao Amor e à Mágoa”. (ISHERWOOD, 1977, p. 15, tradução nossa)

Mas, apesar de toda a sua dignidade, o Instituto não resistiu à ascensão de Hitler e foi o primeiro alvo da campanha nazista contra livros "pouco germânicos" e, já em maio de 1933, foi saqueado e sua biblioteca de 10.000 volumes incinerada em uma fogueira pública junto com um busto do próprio Hirschfeld.

$\mathrm{O}$ advento do nazismo e do stalinismo significou o fim de toda militância homossexual até a conclusão da II Guerra Mundial e foi somente em 1948 que se voltou a retomar a campanha por direitos para os homossexuais. Nos Estados Unidos formou-se o Mattachine Society, inicialmente uma organização semiclandestina que, adotando uma linha de moderação e cautela, visava a integração dos homossexuais na sociedade. Seus associados muitas vezes aceitavam a noção da homossexualidade ser uma doença, frequentemente adotavam pseudônimos e enfatizavam a sua respeitabilidade. A própria palavra "homossexual" era rejeitada devido à sua ênfase no "sexual" e outros neologismos eram adotados como "homófilo" e "homoerótico". Esta postura aparentemente tímida pelos padrões atuais é bastante compreensível, se levarmos em conta a natureza repressiva da sociedade americana de então, e a ameaça constante que o macartismo representava para qualquer atuação política mais radical. Em outros países também começaram a surgir grupos similares, como o Arcadie da Franca, o Forbundet 48 da Dinamarca, o COC da Holanda, etc.

Porém, no final da década de 60 , depois do aparecimento do movimento hippie e da contracultura, após os eventos de maio-junho de 68 em Paris, surgiu o Gay Liberation Front, nos EUA, advogando uma postura muito mais radical e questionadora da sociedade. Para caracterizar a ruptura que ele representou com os métodos tradicionais de 
militância; basta lembrar que o marco simbólico de seu aparecimento foi uma batalha de três noites, travada por homossexuais, incluindo muitos travestis e prostitutos, contra a polícia no gueto gay de Nova York em junho de 1969. A luta foi bastante violenta e os homossexuais, além de evidenciar uma fúria inusitada contra seus tradicionais repressores, também gritaram palavras de ordem insólitas para a época, como:

\author{
Poder Gay \\ Sou bicha e me orgulho disso \\ Eu gosto de rapazes, etc.
}

Poucos meses depois, o Gay Liberation Front, já mais estruturado, lançaria seu próprio jornal, chamado Come Out - que pode ser traduzido como Assuma-se - e consagraria o dia 28 de junho como o "Dia de Orgulho Gay".

O exemplo de Nova Iorque logo foi seguido em outras partes dos Estados Unidos, e também na Europa, onde surgiram grupos radicais que, além de adotarem táticas de luta muito mais diretas e às vezes violentas, tinham reivindicações qualitativamente diferentes. Indo muito além de uma exigência por direitos civis, desprezavam os "homófilos" por desejarem uma integração à sociedade existente. Eles exigiam uma mudança radical na própria sociedade, preconizando a abolição das diferenças entre os papéis sexuais desempenhados pelo homem e pela mulher, juntamente com os padrões estereotipados de masculinidade e feminilidade. Até mesmo a dicotomia hetero/homossexual foi criticada, advogando-se a bissexualização da sociedade. Procurava-se acabar com a sociedade dos "normais", incorporando às táticas de agressão e aos padrões e valores estabelecidos a desmunhecação e outros comportamentos homossexuais extremamente estereotipados, em alguns casos, adotando o travestismo.

O uso da desmunhecação e do escândalo, por parte de militantes homossexuais, é suscetível de várias abordagens e, dada a frequência de sua recorrência, não pode ser ignorado em qualquer abordagem mais aprofundada do tema da militância homossexual. Uma das 
formas interessantes e produtivas de encarar o fenômeno é vê-lo à maneira de Goffman (1968), como uma tática para lidar com uma identidade estigmatizada.

Como ele nos mostra, o indivíduo estigmatizado, além das outras dificuldades inerentes à sua condição específica, ainda está sujeito a um permanente bombardeio de "conselhos" sobre como portar-se e como encarar a sua identidade. Porém, esses conselhos, parecidos com os dados aos responsáveis pela editoria homossexual do jornal esquerdista mencionado anteriormente, são geralmente contraditórios, enfatizando, ao mesmo tempo, a necessidade do estigmatizado se integrar na sociedade tão bem quanto possível e a importância dele não tentar negar o seu estigma e o grupo de estigmatizados ao qual pertence. Dependendo da forma como ele resolve esta charada o indivíduo será então julgado "alienado" ou "autêntico". (GOFFMAN, 1968, p. 135) Mesmo que ele queira ignorar o seu estigma, sempre lhe é cobrado um posicionamento e, portanto, torna-se compreensível, especialmente da parte de indivíduos mais auto afirmativos, um comportamento que, ao menos ocasionalmente, enfatize a condição estigmatizada. Outros indivíduos poderão optar por um modo de ação contrário, adotando uma prática de camuflagem de sua condição estigmatizada. Mas Goffman (1968) nos chama a atenção para o fato de que muitas vezes se espera que o indivíduo se identifique com o agregado de seus companheiros de infortúnio porque este é considerado o seu grupo verdadeiro, aquele ao qual ele pertence naturalmente. Todas as outras categorias ou grupos, aos quais o indivíduo também pertence, não são considerados como realmente seus. Ele não é um deles. Portanto em termos de sua identidade de ego, ou seja, a forma como ele deveria se avaliar, a posição da camuflagem pode ser demasiadamente penosa. (GOFFMAN, 1968, p. 139)

Já vimos como os participantes do Encontro de Homossexuais Organizados do Nordeste, de 1981, adotaram atitudes estereotipadas como maneira de marcar sua presença. Essa prática está também presente em todos os grupos de militância homossexual que eu já tive a oportunidade de ver atuando no Brasil. A propósito, durante uma passeata promovida em 1980 para protestar contra a repressão policial em São Paulo, um dos slogans mais repetidos era: “Agora, já, 
queremos é fechar". ${ }^{2}$ Igualmente, durante bastante tempo entre os grupos de São Paulo, discutiu-se o esvaziamento da conotação pejorativa da palavra "bicha" que passou a ser usada pelos militantes para se referirem uns aos outros.

O que estaria ocorrendo aqui é a recuperação, por parte de militantes, das práticas e de uma linguagem corrente em certos meios homossexuais mais imediatamente visíveis. Sua negação ou reprovação seriam mais uma forma de reprimir os gays mais arrojados e "escandalosos" que, embora de modo até agora desorganizado e pouco teorizado, representariam a ponta de lança da afirmação homossexual. Essa política, porém, é alvo de muitas críticas por parte daqueles que receiam uma nova normatização da homossexualidade. Mas Foucault pode ser invocado aqui para nos ajudar a clarear nossos pensamentos sobre o assunto quando ele discute a polivalência tática dos discursos que, segundo ele, devem ser entendidos como uma multiplicidade de elementos discursivos capazes de entrar em estratégias diferentes. Como ele diz: "É preciso admitir um jogo complexo e instável em que o discurso pode ser, ao mesmo tempo, instrumento e efeito do poder, e também escora, ponto de resistência e ponto de partida de uma estratégia oposta". (FOUCAULT, 1979, p. 96)

Portanto, seguindo sua lógica, reforçar novas categorias ou identidades não é simplesmente normatizar, mas também pode ser uma tática inteligente de resistência para fazer valer as reivindicações de um discurso geralmente desqualificado.

Existe também uma outra discussão possível da questão, informada em parte pela releitura de Freud como a feita por Guattari. Ele fala sobre uma trupe teatral francesa As Mirabelles (GUATTARI, 1981, p. 43), bastante semelhante aos Dzi Croquetes brasileiros. Usavam o travestismo não somente para imitar mulheres mas para perturbar o espectador, questionando suas ideias recebidas a respeito da feminilidade e da masculinidade de uma forma análoga, embora talvez, mais trabalhada, à "fechação" de alguns militantes homossexuais. Segundo ele, aquela trupe de travestis coloca uma nova questão que não é mais

2 Fechar: uma expressão de gíria homossexual que se refere a um comportamento caricato, desmunhecado e escandaloso. 
a de saber se vamos desempenhar o papel feminino contra o masculino, ou o contrário, e sim fazer com que os corpos, todos os corpos, consigam se livrar das representações e dos constrangimentos do "corpo social", bem como das posturas, atitudes e comportamentos estereotipados, da "couraça” de que falava Wilhelm Reich.

Para Guattari (1981) o movimento operário e revolucionário estaria atualmente esclerosado, devido à sua postura de surdez perante os verdadeiros desejos do povo e esta situação só poderia ser remediada se nós pudermos nos colocar à escuta de nosso próprio desejo e daquele de nosso entorno mais imediato. O efeito da atuação das Mirabelles como também o da "fechação" seria então o de explorar, impulsionados pelo nosso desejo, o caminho que nos remete a nossos corpos, um devir-OUTRO, um tornar-se diferente daquilo que o corpo social repressivo nos destinou autoritariamente. Guattari vai mais além na sua formulação e levanta também a ideia de que, embora não se pretenda substituir a luta de classe pelas lutas do desejo, mesmo assim os pontos de junção entre elas trarão àquelas uma energia inimaginável.

Mieli, um antigo militante do movimento homossexual italiano, sustenta posições parecidas. Para ele, os homossexuais, com sua presença, revelam um dos mistérios fundamentais do mundo - a "trans-sexualidade". Ele explica o termo da seguinte forma:

Neste livro denominarei 'trans-sexualidade' a disposição erótica polimorfa e 'indiferenciada' infantil, que a sociedade reprime e que, na vida adulta, todo ser humano carrega consigo em estado de latência ou mantida confinada nos abismos do inconsciente sob o jugo do bloqueio. O termo 'trans-sexualidade' me parece mais idôneo para expressar ao mesmo tempo a pluralidade das tendências do Eros e o hermafroditismo originário e profundo de cada indivíduo. (MIELE, 1979, p. 25, tradução nossa)

Segundo Mieli (1979), a importância da "trans-sexualidade" revelada pelos homossexuais pode ser aquilatada pelo grau de repressão que eles têm sofrido. Hoje o capital estaria tentando estender seu domínio sobre o inconsciente, permitindo que ele apareça em determinadas formas sublimadas e domesticadas. Mas esta pseudoliberalização 
das chamadas "perversões", além de ter fins econômicos imediatos, teria um efeito muito mais importante, favorecendo a submissão de toda a vida humana ao capital. Portanto Mieli recomenda que se assumam posições extremas e intransigentes pela "liberação - conquista de qualquer aspecto do nosso ser-em-devir". (MIELE, 1979, p. 146) Isto implicaria que os homossexuais devem se libertar do sentimento de culpa, a fim de difundir o homoerotismo e induzir os heterossexuais absolutos a descobrir a sua homossexualidade. Dessa forma, contribuiriam, através do confronto e do choque dialético entre a tendência sexual da minoria e a da maioria, para a conquista da trans-sexualidade a que remete a profunda natureza polissexual do desejo. A severidade da repressão sofrida por eles seria evidência de que a maior ameaça apresentada ao sistema constituído era a sexualidade.

Mas as colocações categóricas, tanto de Guattari, quanto de Mieli, às vezes parecem demasiadamente otimistas sobre o efeito revolucionário do travestismo e da fechação. A suposição de Guattari de que uma "energia inimaginável resultaria dos pontos de junção da luta de classes e das lutas do desejo" é frequentemente posta em questão pelo caos e desânimo que rondam os grupos feministas e homossexuais quando estes tentam fazer esta síntese: "Até o potencial perturbador do travestismo é suscetível de ser cooptado pelo status quo".

Durante a campanha eleitoral de 1982, ele foi até usado pelo conservador PDS de São Paulo em showzinhos de fim de semana, organizados pela municipalidade e realizados no coreto da Praça da República, uma região frequentada por migrantes e outros membros de setores marginalizados do centro de São Paulo. A alegação de Mieli de que o potencial revolucionário dos homossexuais, especialmente dos mais escandalosos, pode ser avaliado a partir de repressão que lhes é movida pela sociedade, também deve ser questionada por ser demasiadamente mecânica a relação "repressão social" = "perigo para o sistema". Seguindo esta lógica, teríamos que considerar como perigosíssimos à ordem estabelecida um grupo como o dos ciganos, constantemente enxotados de seus locais de acampamento e vítimas de constante repressão policial. Os menores abandonados e os indigentes que se abrigam embaixo dos viadutos das nossas grandes cidades também teriam que ser considerados de altíssima periculosidade, uma vez que 
parecem suscitar brutais reações repressivas, por parte de policiais, que frequentemente chegam a assassinatos. Feitas essas restrições, concordamos que estes personagens mais escandalosos certamente são dotados de um poder de inquietação que força aqueles ao seu redor a questionarem uma ampla gama de atitudes preconcebidas.

Talvez o mais importante alvo deste questionamento seja a concepção de que haveria um substrato de "naturalidade" para os padrões de masculinidade e feminilidade. Susan Sontag escreveu na década de 60 um artigo seminal chamado Notes on camp que deslanchou toda uma discussão sobre o tema. Lá ela diz que camp - um termo difícil de traduzir, mas equivalente, a grosso modo, ao nosso "fechação" ou "bichice" - seria uma sensibilidade, um tipo de esteticismo, uma forma de ver o mundo como um fenômeno estético, mas não em termos de beleza e sim em termos do grau de artifício e estilização. (SONTAG, 1966) Esta forma de percepção do mundo seria uma decorrência da condição de oprimido do homossexual, que torna possível que ele enxergue a natureza artificial de categorias sociais e a arbitrariedade dos padrões de comportamento. A forca do camp repousa em grande parte no seu humor corrosivo e iconoclasta, disposto a ridicularizar todos e quaisquer valores. Por exemplo, por ocasião da visita do Papa ao Brasil, nos meios homossexuais a solenidade da ocasião era frequentemente esvaziada através de referências ao luxo dos "modelitos" envergados por aquele digno personagem, e quando ele descia do avião, as bichas mais tresloucadas demonstravam séria preocupação que ele pudesse "quebrar seu salto alto" e pôr todo o espetáculo a perder. É neste sentido que Sontag (1966) aponta o camp como sendo um "solvente moral".

Frequentemente esse tipo de atuação "fechativa" é criticado por militantes mais sérios dos movimentos homossexual e feminista que dizem que, além de ser uma reprodução de estereótipos, ele não leva a nenhuma mudança, seu humor funcionando mais como uma forma de anestesia. $\mathrm{O}$ padrão de masculinidade seria mantido como um ponto fixo em relação ao qual as mulheres e os homossexuais masculinos emergiriam como "aquele que não é masculino".

O que provavelmente mais irrita aqueles militantes é a falta de seriedade da "fechação", pois quando todos os valores se tornam objetos 
de zombaria; nem a própria militância escapa. Como Goffman (1968) nos lembra, quando um grupo estigmatizado resolve lutar por direitos, as reivindicações e as estratégias que propõe são todas partes do idioma e dos sentimentos usados pela sociedade como um todo.

Seu desdém por uma sociedade que os rejeita só pode ser entendido nos termos em que aquela sociedade concebe o orgulho, a dignidade e a independência. Em outras palavras, a menos que ele possa recorrer a uma cultura estrangeira, quanto mais ele se separa estruturalmente dos normais, mas ele se torna culturalmente parecido com eles. (GOFFMAN, 1968, p. 139)

Como exemplo desse processo, é relevante notar aqui que ocasionalmente os próprios militantes homossexuais têm insistido que a homossexualidade é tão saudável quanto outras orientações sexuais, sem se aterem ao fato de que o conceito "saudável" remete à discussão da sexualidade mais uma vez ao foro médico-psiquiátrico, que eles tanto rechaçam.

Por ridicularizar todos os valores da sociedade, a "fechação" parece roubar os militantes de pontos de apoio para as suas reivindicações e talvez seja essa a chave para a compreensão do seu poder, que está além da militância social e, em um nível existencial profundo, nos remete ao aspecto lúdico de nossa existência. Guattari (1981) nos diz que As Mirabelles não pretendem ser levadas a sério - suas palavras de ordem são: crise monetária e travesti, bananas e travesti [...]. E parece salutar apontar, através do deboche, para o componente ridículo e absurdo da militância que, ao se opor aos padrões existentes de comportamento sexual, frequentemente determina novos modos e paradigmas que podem tornar-se tão opressivos quanto os velhos. Talvez essa seja uma forma de evitar o surgimento de novos tiranetes.

Sempre haverá aqueles que lembrarão que a luta é séria, que travestis são regularmente torturados e mortos e que muitos homossexuais são desrespeitados em sua dignidade humana. Eles têm razão e a luta por melhores condições de existência sempre é válida. Porém, é bom que fique sempre lembrado que seus novos valores também são arbitrários e não são de nenhuma forma "naturais". Aliás, como dizia, se não me engano, Oscar Wilde: "A naturalidade é uma pose tão difícil de se manter". 


\section{Referências}

ISHERWOOD, C. Christopher and his kind. Nova York: Avon Books, 1977.

FOUCAULT, M. História da sexualidade I: a vontade de saber. 2. ed. Rio de Janeiro: Graal, 1979.

GOFFMAN, E. Stigma: notes on the management of spoiled identity. Londres: Penguin Books, 1968. 


\section{Em defesa do Gueto ${ }^{1}$}

\section{Em guetos, mas bem visíveis}

Tem chamado a atenção nas áreas centrais da cidade e nos postos boêmios paulistanos uma certa explosão de comportamento homossexual. A qualquer hora, à noite especialmente, pode-se ver pessoas do mesmo sexo, geralmente homens, andando abraçadas, às vezes de mãos dadas, às vezes se beijando como forma de saudação, beijos esses não raros dados na boca.

Esse comportamento, anteriormente inconcebível em público, está começando a ter respaldo em várias esferas da sociedade. É verdade que vem ocorrendo de modo mais marcante no mundo do comércio e dos serviços, no qual o mercado homossexual desponta com um novo filão a prometer bons lucros. Não é novidade a exploração comercial do homossexual. Há várias décadas já existiam bares e boates com uma frequência marcadamente homossexual. Eram situados especialmente na área central, em torno da Avenida Ipiranga em São Paulo, na Cinelândia e na Lapa do Rio. Também não são de agora, no

1 Originalmente publicado em: Novos Estudos CEBRAP, São Paulo, v. 2, 1, p. 53-60, abr. 1983. Posteriormente este texto foi encontrado e publicado no livro de Green e Trindade (2005). 
Rio especialmente, bailes carnavalescos como o do Cine São José ou da gafieira Elite, onde homossexuais, normalmente masculinos, podem ter um espaço para se travestir, dançar e até "tirar uns amassos".

Durante a década de 1960, foram abertas em São Paulo algumas boates declaradamente destinadas a uma clientela homossexual de classe média, que procurava locais de encontro onde houvesse maior segurança contra ataques por policiais ou bandidos. De lá para cá, cresceu o número de casas noturnas. Mas foi nos últimos anos, especialmente depois da abertura política, que surgiu uma enxurrada de estabelecimentos diretamente voltados para o mercado gay - bares, boates, discotecas, saunas. Hoje existem em São Paulo e no Rio algumas saunas gays que não deixam nada a dever às suas congêneres de Nova York ou São Francisco. Dotadas de todas as comodidades costumeiras nas melhores casas de banho, elas contam também com salas de repouso individuais ou grupais, projetadas para permitir o máximo de conforto aos fregueses que queiram ter relações sexuais, seja em casais ou em grupo.

Saunas onde havia "caçação", ou seja, paquera homossexual, e ocorriam atos sexuais já existiam há tempos. Mas, nesses lugares, o sexo era uma coisa apressada e furtiva; geralmente havia alguma forma de repressão exercida pela casa, com maior ou menor rigor. A novidade nos estabelecimentos que agora estão surgindo está no fato de serem concebidos e claramente dirigidos a uma freguesia homossexual e encorajarem a atividade sexual; por exemplo, com a exibição de vídeos pornô homossexuais na sala de repouso coletivo. Também nas discotecas gays, embora já há algum tempo se permitisse que casais do mesmo sexo dançassem juntos, beijos ainda eram proibidos, mas aos poucos foi ocorrendo uma liberalização e agora é comum ver pares homossexuais, especialmente homens, trocando beijos "cinematográficos".

Embora não se possa falar em uma revolução na forma como é desempenhado o papel do homossexual nas grandes metrópoles brasileiras, mudanças há. Se elas tomaram ímpeto maior a partir da "abertura", suas raízes começaram a se formar na confluência das décadas de 1950 e 1960, quando surgiram os primeiros shows de travestis, e quando certas casas noturnas, como o João Sebastião Bar, em São Paulo, começaram a ser conhecidas até como lugares "exóticos", "cheios de artistas". 
Cantores como Caubi Peixoto e Araci de Almeida, embora às vezes mantivessem uma fachada heterossexual, eram conhecidos como sendo homossexuais. "Caubi" chegou a virar um termo usado como insulto.

Talvez tenha sido no começo da década de 70, com a volta da Europa de Caetano Veloso e a nova ênfase que os antigos tropicalistas passaram a dar à androginia, que o comportamento homossexual começou a sair dos recintos fechados para se tornar público. Surgiram depois os Dzi Croquetes e o conjunto Secos e Molhados, com o cantor Ney Matogrosso, borrando as linhas demarcatórias entre os gêneros. Somem-se a isso notícias vindas da Europa e dos Estados Unidos falando sobre a "revolução gay" que estaria acontecendo nesses lugares. Em fevereiro de 1976, começou a sair, no jornal Última hora de São Paulo, uma coluna editada por Celso Curi, a "Coluna do Meio", com informações, fofocas e piadas sobre o mundo gay, além de um "correio elegante". Isso, mais tarde, seria motivo de um processo contra o jornalista, acusado de "ofender a moral e os bons costumes". Quando Celso Curi finalmente ganhou a causa, já fora demitido do jornal.

O grande marco mesmo foi o aparecimento do jornal Lampião da Esquina, cujo número experimental circulou pela primeira vez em abril de 1978. Durou três anos, com tiragens mensais de 12 a 15000 exemplares. Embora não fosse a primeira publicação a se dirigir diretamente ao público homossexual, foi a primeira tentativa bem-sucedida de fazer um jornal com reflexões sobre o estilo de vida homossexual que fossem além da superfície sem, contudo, cair numa sisudez atípica do público a que se dirigia. Originalmente se propunha ser mais do que um jornal gay, tentando levantar discussões também sobre a condição dos negros, dos índios e das mulheres, e sobre ecologia. Mas, voltado desde o início predominantemente para os interesses dos homossexuais masculinos, passou a se dirigir cada vez mais a esse grupo. Pouco antes de deixar de circular, em meados de 1981, publicava pacotes de reportagens sobre um mesmo tema como travestis, michês, masturbação, hotéis de "pegação" etc. Ousando falar sobre o até então impublicável, como a série de artigos na qual a masturbação era altamente elogiada como fonte de prazer, o jornal ajudou a ampliar as fronteiras da discussão na imprensa. 
Existiam críticas a ele, é claro. Uma das mais constantes era que o jornal propagava demasiadamente a imagem da "bicha folclórica", cujos principais interesses seriam sexo, plumas e paetês. Demasiadamente voltado ao homossexual que frequenta o gueto, o Lampião estaria esquecendo a enorme parcela que prefere um modo de vida mais discreto, sério, menos visível. Apesar das críticas, o Lampião, mais que qualquer outro órgão da imprensa, abriu e sustentou a discussão sobre a homossexualidade e teve importância ao difundir a ideia de militância política homossexual.

Hoje existem várias revistas voltadas para o mercado gay, de qualidade bastante inferior ao Lampião e de conteúdo basicamente pornográfico. Visando principalmente ao lucro, geralmente trazem artigos um tanto superficiais, muito embora seu conteúdo anti-repressivo acabe questionando vários tabus e proporcionando informações sobre o corpo humano e sobre temas médicos ligados à sexualidade.

Talvez o símbolo máximo da exploração do mercado homossexual seja o baile "Gala Gay" da terça-feira de carnaval, promovido por Guilherme Araújo no Canecão do Rio de Janeiro, que tem contado com milhares de participantes, não obstante ao alto custo do ingresso. Não só o homossexual virou mercado, como também virou mercadoria. De diversos modos sua imagem é vendida ao grande público. Um exemplo? A edição especial da revista Fatos e fotos-gente, de março de 1982, totalmente dedicada a fotos de travestis e com ampla cobertura do baile "Gala Gay".

No mundo musical, alguns artistas, ao invés de esconderem suas preferências sexuais, como faziam antigamente seus colegas homossexuais, agora constroem seus espetáculos em torno de sua sexualidade. Ângela RoRo, por exemplo, passa grande parte de seus shows falando de seus amores lésbicos, tema de boa parte de suas composições. Ney Matogrosso consegue efeitos extraordinários com sua voz aguda, e seus melhores achados cênicos são construídos em torno de uma ambiguidade sexual realçada por maquilagem, roupas e dança. Caetano Veloso, embora não se declare homossexual, também deve ser lembrado aqui: no princípio da década de 70 já aparecia em cena maquilado e usando roupas femininas.

Na televisão o assunto começa a ser abordado em novelas, filmes, conselhos de moda e quadros humorísticos. No teatro, desde há algum 
tempo, a programação de São Paulo e Rio contava regularmente com várias peças abordando o assunto de uma forma ou de outra. O que está mudando não é apenas a quantidade de espetáculos em cartaz simultaneamente a tratar do assunto - recentemente havia cinco no Rio e três em São Paulo -, como também a forma de encenação, que inclui cenas de nudez, beijos na boca e até coito anal simulado.

Um dos aspectos mais interessantes dessa aparição da homossexualidade em público é a vertente que o trata como postura política. Neste caso, o Lampião teve um papel pioneiro, no qual foi quase simultaneamente acompanhado por um grupo de homens em São Paulo, dando origem mais tarde ao Grupo Somos-SP. Hoje em dia há grupos em várias cidades do Brasil, como todos são autônomos, é bastante difícil caracterizar seus traços gerais, mas pode-se dizer que, a grosso modo, elegeram o machismo e a sociedade patriarcal como alvo de seus ataques. Estes grupos geralmente têm como preocupação provocar mudanças na atitude repressora da sociedade, mas a atuação em que, a meu ver, acabam sendo mais bem-sucedidos consiste em reuniões de reflexão em que são debatidos temas trazidos pelo relato das histórias de vida de seus integrantes.

A atuação externa desses grupos tem um efeito propagandístico especialmente importante. Dada a propensão da mídia a explorar o filão homossexual, suas manifestações recebem cobertura e são bastante discutidas. Haja vista a passeata de protesto organizada contra a "Operação Rondão” do delegado Richetti da Seccional Centro de São Paulo. Na virada de 1979 a 1980, as áreas que formam o gueto homossexual de São Paulo passaram a gozar de uma liberdade sem precedentes. Nesses lugares, o beijo entre homens, o segurar de mãos, o exibicionismo dos travestis tornaram-se rotineiros, chegando a um ponto intolerável para certos setores da sociedade. O Estado de São Paulo publicou uma série de artigos extremamente violentos, atacando os travestis. Pouco depois, começava a “Operação Rondão”. Durante semanas as áreas mais frequentadas pelos homossexuais paulistanos foram sistematicamente atacadas pela polícia, conseguindo afastar das ruas quase toda manifestação de comportamento homossexual. Alegando estar à procura de bandidos foragidos, a polícia prendia toda pessoa que estivesse sem carteira de trabalho assinada. Além de ser uma forma de ação muito 
ineficiente - em um fim de semana, por exemplo, foram presas mais de quinhentas pessoas das quais nem dez eram procuradas -, a operação foi muito violenta; atemorizou não apenas os homossexuais, mas também outros frequentadores noturnos do centro da cidade-prostitutas, negros, estudantes, artistas, desempregados, etc. Em protesto contra tais arbitrariedades, grupos homossexuais aliados às feministas e ao Movimento Negro Unificado organizaram uma passeata que contou com quase mil participantes. Aliás, grupos homossexuais também têm participado de passeatas e atos públicos organizados pelas feministas e pelos negros. Alguns entendem que o movimento mais próximo a eles é o feminista. Especialmente depois que as lésbicas começaram a se colocar como lésbicas feministas e a conquistar espaço entre as organizações de mulheres, os homossexuais passaram a ter interesse crescente por este movimento e a participar de suas atividades.

Também em nível político-partidário a questão está sendo debatida e, neste ano (1983), alguns candidatos a vereador e a deputado, tanto no PMDB quanto no PT, incluíram em suas plataformas reivindicações dos grupos homossexuais. A principal delas é a exigência da abolição do código 302.0 do Instituto Nacional de Assistência Médica e Previdência Social (INAMPS), que rotula o "homossexualismo" como "desvio e transtorno mental".

Com todos esses fatores em operação, hoje se divulga muito mais informação sobre a homossexualidade do que alguns anos atrás. Vão se levantando um pouco os véus de mistério e maldição que envolviam o assunto. A própria palavra gay, originalmente restrita aos meios homossexuais dos países de língua inglesa, é agora conhecida de todos e usada como expressão muito menos carregada negativamente; sem as conotações de seriedade do termo "homossexual", tem se prestado otimamente à comercialização: a origem anglo-saxônica empresta-lhe um glamour de coisa de país desenvolvido.

\section{Autoimagem positiva}

Aos poucos, cresce o número de pessoas que assumem a identidade homossexual, dando coragem a outros de fazer o mesmo. O aumento do número de homossexuais visíveis tem levado a população como 
um todo a dar mais atenção ao fenômeno e tem promovido a ideia de que podem existir diversas orientações sexuais, todas válidas. Apesar de os grupos homossexuais dizerem não desejá-la, parece haver uma tendência à integração na sociedade. Afinal, talvez a sociedade não tenha de sofrer mudanças muito radicais para permitir alguma acomodação, alguma convivência.

Concomitantemente às mudanças, que ocorrem no nível social mais amplo, estão alterando a forma como os homossexuais se veem e se relacionam entre si. Em primeiro lugar, a diminuição da carga de sentimento de culpa que pesa sobre esses indivíduos. Com o declínio da importância da religião cristã como fator normativo da sociedade urbanizada e de consumo conspícuo, há uma tendência a deixar de ver o prazer sexual como intrinsecamente pecaminoso. Novos conceitos entram no lugar do antigo pecado: anormalidade, doença, desvio, etc. Embora carregados negativamente, possuem a vantagem de se reportar ao mundo racional, passíveis, portanto, de questionamento através da razão. É muito mais fácil, por exemplo, argumentar que a "natureza" é um conceito relativo e que, portanto, a "antinaturalidade" da homossexualidade também o é, do que ir contra preceitos bíblicos baseados numa suposta revelação divina. Embora continue a vigorar uma série de fatores inconscientes, acessíveis só através de análises profundas, é inegável que discussões entre amigos e a força do exemplo ajudem imensamente as pessoas a se sentirem menos culpadas em relação à sua conduta sexual. Não é à toa que uma das atividades mais bem sucedidas dos grupos homossexuais seja a formação de grupos de reflexão e troca de experiências. De maneira mais informal, o mesmo processo se repete nos bares, discotecas e outros estabelecimentos que compõem o chamado gueto homossexual.

\section{A importância do gueto}

Os sentimentos de culpa e pecado que oprimem o homossexual são constantemente repostos por fatores sociais que o levam a se ocultar, a ter medo do ridículo, da prisão, do desemprego, do ostracismo por parte de amigos e familiares. O gueto é um lugar onde tais pressões são momentaneamente afastadas e, portanto, onde o homossexual 
tem mais condições de se assumir e de testar uma nova identidade social. Uma vez construída a nova identidade, ele adquire coragem para assumi-la em âmbitos menos restritos e, em muitos casos, pode vir a ser conhecido como homossexual em todos os meios que frequenta. Por isso é da maior importância a existência do gueto. Mais cedo ou mais tarde, acaba afetando outras áreas da sociedade.

Como parte do esforço por fazer com que tanto a sociedade como um todo quanto os indivíduos homossexuais reavaliem a imagem do homossexual, alguns dos grupos têm promovido uma revalorização das palavras "lésbica" e "bicha". Promove-se o uso dessas palavras no linguajar corriqueiro. Entre os envolvidos nos grupos é praxe o uso desses termos referindo-se a si próprios. Procura-se esvaziá-los de sua carga pejorativa. Diz-se que, uma vez que os homossexuais consigam assumir certos rótulos sem sentimento de culpa ou inferioridade, se terá roubado uma das grandes armas dos seus perseguidores.

Além de exibirem maior dose de autoconfiança em suas relações com a sociedade como um todo, os homossexuais também estão mudando as formas de se relacionar entre si. Tradicionalmente, em se tratando de papéis sexuais, a sociedade divide os indivíduos em dois: o homem e a mulher, o ativo e o passivo. Essa divisão em dois tipos é extremamente arraigada na cultura e não surpreende que se encontre reproduzida nas relações homossexuais, os homens classificando-se como "bofe" e "bicha" e as mulheres como "fanchona" e "lady". Em ambos os casos, os primeiros seriam "ativos" e os segundos "passivos", produzindo-se relações de dominação vigentes entre homens e mulheres. Mas, assim como entre homem e mulher estão ocorrendo mudanças notáveis, também entre casais homossexuais está se dando uma diluição da dicotomia ativo/passivo, a par de maior democratização do relacionamento. Isto parece ocorrer principalmente entre moradores de cidades grandes, de níveis socioeconômico e educacional mais elevados. Desloca-se a ênfase dos detalhes do ato sexual - quem penetra quem - para o relacionamento visto de maneira mais abrangente, isto é, o que importa é com quem você se relaciona, se com pessoas do seu próprio sexo ou não. Estas pessoas, que se definem não mais como ativas ou passivas, mas sim como heterossexuais ou homossexuais, questionam a validade de 
papéis preestabelecidos e muitas vezes sentem-se extremamente constrangidas se forçadas a exercê-los. (FRY, 1982)

Esse questionamento das normas tradicionais não raro se estende a outros conceitos tomados de empréstimo do casamento heterossexual: a fidelidade, por exemplo. Neste caso, considerando a exigência de fidelidade do parceiro uma ideia baseada na necessidade de transmissão da propriedade e de criação dos filhos, alguns, especialmente homens, começam a questionar sua aplicabilidade aos homossexuais. Alimenta ainda mais essa dúvida a propensão à promiscuidade, amplamente constatada entre os homossexuais masculinos: muitos se recusam a assumir qualquer compromisso mais estável, temendo ter sua liberdade tolhida.

Começam a se alastrar os "casos abertos", em que os parceiros estabelecem uma espécie de acordo que permite relações com terceiros sem ameaça ao "caso". Em parte, pela falta de qualquer parâmetro preexistente, esses "casos" às vezes se tornam complicados, mas entre aqueles que se julgam "progressistas" - como os engajados no Movimento Homossexual - "casos fechados" são às vezes considerados castradores, irrealistas, geradores de hipocrisia e, ofensa final, "machistas".

Entre as lésbicas, provavelmente por causa da educação diferenciada que exalta a promiscuidade masculina enquanto reprime toda manifestação de sexualidade feminina, os "casos" tendem a ser mais "fechados". Mas também entre elas a predominância das divisões de papéis tradicionais leva, às vezes, a situações caricaturais em que a "fanchona" adota o comportamento promíscuo, socialmente reservado ao homem, e exige fidelidade absoluta de "sua mulher".

Na época da mobilização contra o delegado Richetti, solicitou-se o auxílio de deputados da oposição, bem como de representantes dos setores ditos democráticos (sindicatos, $\mathrm{OAB}$, Comissão de Justiça e Paz, etc.). Embora mostrassem uma certa receptividade, essas entidades e esses políticos, receosos talvez de se "sujar" perante seu público, enfocaram somente a questão dos direitos humanos, evitando ao máximo até mesmo a menção da palavra "homossexual". Durante a passeata de protesto nenhum deles compareceu. A única pessoa de renome a estar presente foi o pintor e escritor Darci Penteado, que há tempos se identifica com a causa homossexual. 
Também na esquerda há posições abertamente anti-homossexuais. Quando em 1980 organizou-se um ato público contra os atentados terroristas da direita, militantes de um determinado grupo saíram pelas ruas convocando o povo a um protesto contra os "maricas fascistas". Esse tipo de posicionamento ocorre de vez em quando no jornal Hora do Povo. No seu número de 6 de fevereiro de 1981, um artigo atacava as "autonomistas" do movimento feminista: grã-finas desorientadas, lideradas por lésbicas! Acima do artigo, uma charge assinada por Maringoni em que apareciam, entre outras mulheres, duas lésbicas, uma tendo um ataque histérico ao ver mulheres do povo, enquanto a outra, caricaturalmente "machona", tenta levá-la para casa.

Persiste ainda em várias áreas a dicotomia bofe/bicha, ativo/ passivo. Nos meios de comunicação de massa ainda se continua a propagar a visão que associa o homossexual ao passivo; com raras exceções, o “desmunhecar" é essencial para qualquer representação desse tipo de personalidade. Por outro lado, mesmo entre homossexuais, as chamadas "bichas pintosas" - os homens muito efeminados - sofrem muita discriminação por parte daqueles que internalizaram os preconceitos da sociedade, extravasando-os sobre os indivíduos que veem como mais escandalosos cuja companhia pode ser comprometedora.

Essa divisão entre "bicha" e "bofe" leva também a um acirramento da misoginia latente em muitos homossexuais masculinos. Isso porque a "bicha" às vezes se considera em competição direta com as mulheres - pejorativamente chamadas de "rachadas" - e em inferioridade de condições.

Como parte da constelação de atitudes em torno da dicotomia "bicha/bofe", há a tendência a compartimentalizar as emoções, separando a atividade sexual do mundo afetivo. Na relação "bicha/bofe" isso é bastante comum e parece ter sua razão de ser, uma vez que o "bofe" teria sua virilidade questionada se mantivesse qualquer relacionamento mais profundo ou duradouro com uma "bicha". Consequentemente, ambos logo aprendem a não investir seus sentimentos nessas relações. Esse processo também é encontradiço entre homossexuais que já romperam com a divisão dos papéis sexuais. A proliferação de saunas gay onde as relações sexuais ocorrem entre parceiros 
que só se veem na penumbra ou entre nuvens de vapor, às vezes sem mesmo dizerem seus nomes, vem reforçar esta separação sexo/afeto.

\section{Homens e mulheres}

Olhando o mundo homossexual de hoje, percebe-se a diferença existente entre a situação dos homossexuais masculinos e a das lésbicas. Os homens são muito mais visíveis e o seu gueto é bem maior, contando com numerosos bares, discotecas e saunas, enquanto as mulheres têm muito menos opções como pontos de encontro. Por um lado, a maior repressão sofrida pelas mulheres em geral leva as lésbicas - tanto quanto as heterossexuais - a saírem menos sozinhas, a serem mais tímidas a manifestações abertas de sua sexualidade; são mais "enrustidas", menos visíveis. Outro fator é puramente econômico: as mulheres ganham menos que os homens e, claro, constituem um mercado consumidor menos atraente. Não obstante, há sinais de mudanças. Começam a surgir mais bares e discotecas frequentados predominantemente por mulheres, notadamente no centro de São Paulo.

Talvez pelo fato de a subcultura lésbica ainda ser pouco desenvolvida entre elas, persiste com maior força a divisão de papéis ativo/ passivo. A maior durabilidade dos seus casos de amor seria, segundo alguns, resultado dessa apropriação mais completa do modelo heterossexual que enfatiza o caráter permanente do casamento. Entre homossexuais masculinos, os papéis mais igualitários levariam talvez os dois parceiros a se acharem com o direito de procurar satisfação sexual onde quiserem; existem menos regras de conduta e, portanto, há maior instabilidade. Um fator que pesa nessa diferença é sem dúvida a já mencionada educação diferenciada, que enfatiza muito mais a natureza promíscua do homem do que a da mulher.

Mas entre as mulheres a concepção tradicional dos papéis também está sendo questionada. Especialmente pelas que se ligaram de alguma forma aos movimentos feministas e homossexuais. Embora estas lésbicas "conscientizadas" tendam a não frequentar o gueto e a ser incompreendidas por suas frequentadoras, é provável que tenham uma influência indireta, se por nenhuma outra razão, ao menos 
por causa da cobertura que ocasionalmente recebem dos meios de comunicação. Não se deve esquecer também que em certas ocasiões elas têm procurado desenvolver um trabalho mais intensivo junto a essas mulheres - como a série de bingos que elas organizaram aos domingos numa discoteca de lésbicas em São Paulo.

Ao relacionarmos a persistência da divisão de papéis sexuais entre mulheres ao menor desenvolvimento do gueto e, portanto, da subcultura lésbica, vemos a importância que pode ter esse espaço como local de refúgio e como foco gerador de novos padrões de atitudes. A partir daí, vê-se o quanto é séria a ameaça a esta região por parte das forças policiais. Embora seja improvável o fechamento completo de todos os estabelecimentos gay, dada a suscetibilidade das autoridades policiais ao suborno, ele excluiria os mais pobres, impossibilitados de pagar os altos preços das discotecas, saunas e bares. Não é de surpreender que a primeira passeata política, abertamente homossexual, visasse defender justamente este espaço livre.

Entre os homossexuais também há quem despreze o "gueto". Alguns até defendem a posição de que ali não é o local adequado para suas atividades políticas, preferindo a militância em outras organizações como sindicatos e partidos. Outros, porém, acham que se deve valorizar aquele espaço, para eles um importante foco de resistência, tentando expandi-lo por toda a cidade e procurando uma diluição natural de suas fronteiras. Embora idealmente o homossexual não devesse ser encarado como uma coisa à parte - dizem eles - do modo como as coisas estão é necessário que se fale ao máximo para afirmar perante a sociedade a igual validade desta orientação sexual.

O ex-militante francês do movimento homossexual FHAR (Front Homosexuel d'Action Révolutionnaire), Guy Hocquenghem, em seu livro A contestação homossexual, levanta o problema: talvez o que esteja ocorrendo no momento seja simplesmente um remapeamento do que pode ser considerado comportamento lícito e ilícito. As ligações homossexuais seriam agora mais aceitas, mas teriam que se submeter a novas regulamentações. Estas excluiriam relações inter-raciais, inter-classes e entre pessoas de idades muito díspares. Se formos examinar a situação nas grandes metrópoles brasileiras, veremos que aqui o aparecimento de espaços comerciais onde o 
comportamento homossexual é permitido tende, de fato, a segregar as pessoas em termos econômicos e, portanto, raciais. As leis que proíbem a entrada de menores nesses recintos também servem para manter uma divisão entre idades. Mas não devemos simplificar demais a questão. É necessário lembrar que, especialmente entre os homossexuais masculinos, a atração sexual é vista como sendo principalmente física: dois homens de distinta posição social podem cruzar olhares na rua, parar para conversar e em poucos minutos estar juntos na cama. A aventura e o gosto pelo desconhecido continuam a ser prezadíssimos condimentos de uma "transa".

Isto nos leva a uma questão até o momento pouco discutida, mas que me tem ocorrido com frequência, especialmente em momentos de desentendimento entre militantes feministas e homossexuais especialmente masculinos. Embora estes dois movimentos pareçam partir de premissas parecidas, questionando as atitudes machistas encontradas na sociedade, existe entre setores desses movimentos uma diferença básica. As feministas se propõem a mudanças radicais, não só da sociedade como um todo, mas também de si mesmas. A partir de uma crítica da educação diferenciada e do efeito que isso tem sobre todas as mulheres, elas, em alguns grupos mais do que em outros, pretendem lutar contra as suas tendências a se conformar aos padrões psicológicos definidos como femininos: personalidades maleáveis e submissas, dependentes e pouco assertivas. Ao mesmo tempo, estão muito atentas para não deixar outras mulheres assumirem as posições dominadoras antes ocupadas por homens. Essas preocupações levam a uma posição de amplo questionamento de si próprias e até de sentimentos que poderiam parecer naturais, como ciúme e possessividade. Os homens homossexuais, por outro lado, partem da premissa de que sempre foram reprimidos em seus desejos. Ao se organizarem, sentem que um dos seus atos políticos mais importantes está em extravasá-los o mais abertamente possível. Dessa forma, até o desempenho de papéis sexuais dos mais estereotipados do tipo "bicha/bofe" são legitimados, e qualquer questionamento pode passar a ser encarado como moralismo. Além do exemplo citado dos papéis sexuais, desentendimentos entre militantes dos dois movimentos existem em potencial em muitas questões. Entre elas a 
questão da promiscuidade e da pornografia que, por dissociarem o contato sexual de um contato mais profundo e afetivo, são vistas por muitas feministas como desumanizadoras e machistas.

Ao pensarmos sobre a questão da reprodução dos papeis sexuais, não podemos deixar de levar em conta as travestis e transexuais. Estes indivíduos costumam recorrer a dolorosos procedimentos cirúrgicos, muitas vezes realizados em condições de grande precariedade, com o intento de adquirir características externas do sexo oposto. Muitas vezes são criticadas por militantes feministas ou até homossexuais que as acusam de reproduzir e reforçar a organização tradicional dos papeis sexuais. Outros, porém consideram que seu sucesso em reproduzir as formas e o comportamento geralmente associados ao outro gênero contribui para uma subversão da ideologia que prega a sua "naturalidade". Seria o que os anglo-saxões chamam de genderfucking

A maioria dos homossexuais parece nutrir profundo desprezo e antipatia pelas travestis; estas simplesmente alimentariam os preconceitos dos heterossexuais que acreditam que todo homem homossexual deseja, no fundo, virar mulher. Mesmo a chamada "bicha pintosa" já começa a sofrer essa discriminação. A resposta que as travestis dão às críticas é que seriam elas as verdadeiras homossexuais assumidas e que sempre teriam formado a vanguarda, abrindo novos espaços e enfrentando as repressões mais violentas. Como dizem: "Para ser travesti é preciso ser muito macho"

Segundo Weeks (1977), embora o papel do homossexual tivesse começado a aparecer antes, sua cristalização na Inglaterra só se deu no século XIX, justamente quando ocorria uma reestruturação da família e das relações sexuais em virtude do triunfo do capitalismo industrial e da urbanização. Este foi um período marcado pela exclusão das mulheres do mercado de trabalho, da criação de uma massa operária que dependia do sistema familiar para se reproduzir e se manter. Os papéis sociais, representados pelos dois sexos, tornaram-se mais claramente definidos e a homossexualidade - especialmente a masculina - tornou-se uma ameaça a esse sistema. Por isso foi preciso contê-lo e a criação de um papel homossexual estigmatizado serve para manter a massa da sociedade dentro dos padrões. Isso ocorre de duas formas: 
a) Fornece um limite preciso entre o comportamento permissível e o não permissível;

b) Leva a uma segregação daqueles que são rotulados de "desviantes" dos outros membros da sociedade e dessa forma contém e limita os seus padrões comportamentais.

É interessante notar que hoje, quando se começa a falar sobre a desintegração da família, também começam a surgir os movimentos de contestação gay. Tentativamente poderíamos dizer que atualmente, nos grandes centros metropolitanos, muitas das funções tradicionais da família, como reprodutora da força de trabalho, estão mudando de importância. Nessas cidades, agora, é comum a mulher trabalhar fora de casa e os dois sexos terem uma educação cada vez mais semelhante. As tradicionais tarefas domésticas outrora reservadas às mulheres estão se tornando mais leves graças aos auxílios que a tecnologia fornece. A tarefa de educação das crianças está mais socializada. No seio da família ocorrem mudanças radicais como resultado da perda do monopólio do poder econômico por parte do pai.

Por outro lado, a moderna sociedade de massas, presidida por grandes burocracias estatais e privadas, torna-se cada vez mais impessoal. Ora, apesar de todos os seus defeitos, é a família que tem fornecido ao indivíduo um lastro de permanência e uma base para seus valores. Pois bem. E se isto não mais interessar tanto ao sistema econômico de hoje que, nas grandes cidades como São Paulo e Rio, enfatiza cada vez mais a importância de um pseudo individualismo consumista? Dentro deste contexto pode-se entender melhor por que, de repente nos centros mais desenvolvidos do mundo, se começa a cogitar o aborto livre, os meios de comunicação de massa veiculam ideias de liberação feminina e o divórcio torna-se cada vez mais rotineiro. É relevante notar que vem crescendo também o número de bares, salões de dança, saunas, etc., onde os heterossexuais podem compartilhar do sexo impessoal.

Não é de se estranhar que a homossexualidade, de repente, parece se tornar mais aceita. Afinal, em vez de uma ameaça ao sistema, pode até conter certos traços a ser imitados. Claro que isto não passa de uma possível tendência, contra a qual persistem fortes barreiras sociais, estruturais e atitudinais. 


\section{Referências}

GREEN, J.; TRINDADE, R. (Org.). Homossexualismo em São Paulo e outros escritos. São Paulo: Ed. UNESP, 2005.

FRY, P. Para inglês ver: identidade e política na cultura brasileira. Rio de Janeiro: Zahar, 1982.

WEEKS, J. Coming Out: homosexual politics in Britain, from the nineteenth century to the present. Londres: Quartet Books, 1977. 


\section{Afirmação da identidade homossexual: seus perigos e sua importância ${ }^{1}$}

Desde meados de 1979, têm existido no Brasil, com níveis de atividade variável, grupos dedicados a mudar a forma preconceituosa com que são encarados os homossexuais e combater a sua marginalização. Mas da mesma forma que os outros movimentos reivindicatórios, como o feminista e o negro, que privilegiam a questão de identidade mais do que a de classe, o movimento homossexual tem sofrido uma série de questionamentos acerca de sua validade. Uma das dúvidas frequentemente levantadas concerne o resultado possivelmente opressivo que pode ter a atitude de seus ativistas de aceitarem e até exibirem com orgulho o rótulo "homossexual". O que se propõe aqui é pensar um pouco sobre esta questão, à luz do pensamento de Michel Foucault sobre a questão do poder e do "dispositivo da sexualidade".

1 Texto publicado originalmente em: TRONCA, İ. A. (Org.). Foucault vivo. Campinas, SP: Pontes, 1987. 
Ultimamente, tem-se procurado entender a sexualidade não como expressão de uma essência humana, mas como uma construção social que deve ser vista dentro de seu contexto histórico. Como Padgug (1979) diz, a marca distintiva da sexualidade humana é o papel desempenhado em sua construção pela linguagem, consciência, simbolismo e trabalho que, tomados como um todo, são práxis, a produção e a reprodução da vida humana. O conteúdo da sexualidade é fornecido, em última instância, pelas relações sociais humanas, as atividades produtivas e a consciência. A história da sexualidade é, portanto, a história de algo cujos significados e conteúdos estão em um processo de mudança contínua. É a história das relações humanas. Embora certas atividades sexuais, pelo menos quando vistas de um ponto altamente generalizante, sejam comuns a todas as sociedades humanas, seus significados não são sempre os mesmos. Por exemplo, o erotismo dos místicos cristãos não pode ser reduzido àquele de Henry Miller, e o ascetismo de um monge não é idêntico àquele de camponeses irlandeses que retardam seus casamentos até uma idade relativamente avançada. Tampouco é válido igualar o comportamento homossexual da Grécia Antiga àquele de São Francisco hoje.

Foucault (1979), para quem a ascensão do "dispositivo da sexualidade" ocorreu no século XVIII, chama nossa atenção para a transformação ocorrida com o "sodomita", que até então era visto como um mero delinquente e depois começou a ser considerado membro de uma espécie. Antes, o que era proibido era o ato de sodomia, um termo vago que cobria vários tipos de sexo não procriativo. (FOUCALT, 1979)

Tentando esclarecer mais as bases para uma história da homossexualidade, Weeks (1981) examina a cristalização da categoria "homossexual" e situa a especulação médica e científica sobre o assunto no contexto de um processo que ocorreu no século XIX e que levou a uma diferenciação entre os tradicionais "crimes contra a natureza". Estes, até então, eram vistos de uma forma monolítica que associava, por exemplo, a homossexualidade com a masturbação e o uso de contraceptivos. Passou-se a pensar em termos de diversos desvios cujas etiologias foram traçadas no fim do século passado e no começo deste por autores como Krafft-Ebbing, Havelock Ellis, Hirschfeld etc. Por outro lado, como mostrou Foucault (1979), o aparecimento 
do conceito "homossexual" é também relacionado à classificação e à articulação de uma variedade de categorias sociais: as redefinições de infância e adolescência, a mulher histérica, o casal que adota o planejamento familiar. O conceito também tem ligações com os debates de então, em torno da definição do papel de dona-de-casa e mãe. Essa concepção não teria sido o simples resultado da imposição de uma nova definição, mas sim o resultado de várias pressões e forças e da fusão de novos conceitos com velhas definições.

Se adotarmos este ponto de vista, e rejeitarmos a noção de uma "essência" ou de uma "natureza" homossexual, o movimento homossexual então nos parece como abrigando uma importante contradição em seu seio. De um lado temos o desejo expresso de se acabar radicalmente com qualquer tipo de regulamentação da vida sexual, enquanto por outro lado existe uma rígida imposição de categorias. No Somos-SP, como em todos os outros grupos homossexuais brasileiros sobre os quais tenho dados, não se permite a participação de indivíduos que se identifiquem como "heterossexuais" e até os "bissexuais" são encarados com certa reserva e suspeita. O Grupo de Atuação Lésbica Feminista (GALF) vai mais além e só admite como integrantes homossexuais femininas. Estes grupos poderiam ser acusados de contribuírem, de fato, para o reforço do rótulo "homossexual", visto como uma forma de controle social, seja ele imposto a um indivíduo por forças sociais externas, ou seja, ele voluntariamente adotado. A prática de se "assumir", incentivada pelos grupos, correria então o risco de não ser nada revolucionária e o que talvez estaria ocorrendo seria simplesmente uma acomodação de comportamentos e sentimentos, até então, em desarmonia com as normas gerais, integrando-as de uma maneira mais funcional à estrutura vigente. Novos padrões estariam sendo estabelecidos e a linha de demarcação, entre o permitido e o proibido simplesmente mudaria de lugar. Aceitaria-se, por exemplo, o "homossexual comportado", cujos valores e forma de vida se aproximam bastante das dos heterossexuais, mas continuaria a rejeição daqueles personagens mais incômodos, como os travestis, os pedófilos etc. Hocquenghem, um desiludido ex-militante do grupo homossexual francês FHAR antevê um momento em que os movimentos feminista e homossexual, com suas contestações sexuais, se 
imobilizarão em um novo estatuto que os meios de comunicação do Ocidente tratariam de massificar.

O desbloqueamento dos impulsos sexuais, a generalização do debate radiofônico sobre os segredos do desejo caminharam curiosamente passo a passo com a reação moralizadora e afinal de contas anti-sexo do movimento feminista. De certo modo, a "militância homossexual", no sentido mais amplo do termo, é a única resposta masculina ao feminino autotranscendentalista, o qual se proclama dotado de uma essência particular. À liberalização dos costumes, à pornografia e à explosão homossexual responde o novo puritanismo das ligas das mulheres contra a violação. Os dois adversários se tateiam e são as futuras Figuras Dominantes, prontas para entrar em ação. Organiza-se uma nova paisagem da qual os Estados Unidos já podem nos fornecer uma primeira imagem. A futura ordem sexual não está fundamentada como algo que exerça uma ordem repressiva sobre a Natureza. Divide racionalmente um setor liberado, aquele que se refere a um erotismo cada vez mais confessado e comercializado, praticado entre machos e um setor protegido, mulheres que se recusam às carícias brutais, crianças postas a salvo da sanha dos pederastas. (HOCQUENGHEM, 1980)

No Brasil também se levantam dúvidas semelhantes. Em artigo publicado pela Folha de São Paulo, por exemplo, Peter Fry distingue entre duas formas de abordar a homossexualidade. Segundo ele, pode-se fazer duas perguntas: "Fulano é ou não é homossexual?", ou então: “Sicrana transa mulher? ". Destas duas ele prefere a segunda, pois como diz:

A pergunta supõe que o desejo sexual por um parceiro do mesmo sexo é apenas um aspecto das atividades da pessoa, e que qualquer um tem esse aspecto em potencial. Em suma, a primeira pergunta supõe que as pessoas são homossexuais, heterossexuais ou bissexuais, enquanto a segunda tem como pressuposto que as pessoas estão circunstancialmente qualquer uma dessas coisas.

A movimentação em torno da defesa dos "homossexuais" tem por objetivo a libertação sexual, mas contribui noutro sentido, para um novo controle da sexualidade... Ao pressionar pessoas a seguirem determinadas carreiras sexuais, corre-se o risco de desempenhar o papel de eliminar a anomalia e a 
ambiguidade da vida da sociedade e do indivíduo. São apresentadas duas opções excludentes que deixam de lado muitas outras. (FRY, 1982, p. 3)

Embora reconhecendo a importância da consolidação da categoria "homossexual" para combater o estigma social, ele pergunta se o conforto de um gueto bem arrumado é tudo que se pode desejar e termina:

Fourier sonhou com uma sociedade assim, toda divididinha em compartimentos especializados. Mas não seria também possível sonhar com um outro tipo de sociedade menos categórica? Talvez não, mas a supressão da pergunta 'afinal de contas é ou não é?', e a sua definitiva substituição pela segunda, 'sicrana (fulano) transa mulher (homem)?', poderia ser um passo, ao menos, interessante. (FRY, 1982, p. 3)

Jean-Claude Bernardet, discutindo a questão de se definir ou não como homossexual, diz que entrar numa categoria pode ser tranquilizador, mas é também castrador:

Homossexualidade não é privativo dos homossexuais, nem heterossexualidade de heterossexuais, nem masculinidade de homens, nem feminilidade de mulheres. Homo e heterossexualidade não designam estados, mas formas ou possibilidades de comportamento extensivas ao conjunto do corpo social, envolvendo todas as pessoas independentemente da forma específica de sua genitalidade e da prática sexual a que se entregam exclusiva ou predominantemente. A definição como homo ou heterossexual remete ao ser, à essência de um ser, idêntico a si próprio, pedra de toque, princípio central organizador e aferidor de tudo o mais. Fissuras profundas desestabilizaram esse ser e as colmatagens aqui e lá não convencem muito. Esse ser (aos pedaços) não seduz mais, não é mais o rei de nosso imaginário, não é mais um princípio produtor de poesia. O que nos atrai, nos seduz, o que vivemos hoje como princípio produtor, é o movimento, o fluir ambíguo. Antes as funções que o ser. (BERNADET, 1982)

Tanto Fry (1982) quanto Bernardet (1982), ao negarem o “ser”, favorecendo um "estar" ou um "fluir" parecem estar rejeitando qualquer noção mais rígida de "essência" e até de identidade homossexual. Assim como Hocquenghem (1980), apontam para o perigo da simples normatização e recuperação do antigo “desvio” homossexual. 
Embora inicialmente alguns dos grupos não tenham tido muita consciência dos perigos que isso representa, hoje não é mais justo acusá-los de não pensar no assunto e o questionamento da "naturalidade" da homossexualidade se tornou corriqueiro pelo menos entre os grupos paulistas. Isto apesar de que seus integrantes se mostrassem um pouco perplexos a respeito das implicações concretas desta nova forma de encararem sua sexualidade, e nos planos prático e afetivo continuou a predominar uma atitude de "nós e eles" ou homossexuais versus heterossexuais. Sem dúvida o mais importante trabalho dos grupos continuou sendo a "afirmação homossexual" - termo usado pelo Somos-SP como parte de seu nome oficial -, ou seja, a constante reiteração pública ou privada da validade de tal orientação sexual, além do apoio dado às pessoas que se identificam como homossexuais e a exigência que seus direitos de cidadãos sejam respeitados. Àqueles que receiam que isto acabe simplesmente levando à calcificação de novos padrões sexuais chamamos a atenção para a seguinte colocação de Michel Foucault.

deve-se conceber o discurso como uma série de segmentos descontínuos, cuja função tática não é uniforme nem estável. Mais precisamente, não se deve imaginar um mundo do discurso dividido entre o discurso admitido e o discurso excluído, ou entre o discurso dominante e o dominado; mas, ao contrário, como uma multiplicidade de elementos discursivos que podem entrar em estratégias diferentes. . É preciso admitir um jogo complexo e instável em que o discurso pode ser, ao mesmo tempo, instrumento e efeitos do poder, e também obstáculo, escora, ponto de resistência e ponto de partida de uma estratégia oposta. . Ora o aparecimento no século XIX, na psiquiatria, na jurisprudência e na própria literatura, de toda uma série de discursos sobre as espécies e subespécies de homossexualidade, inversão, pederastia e 'hermafroditismo psíquico' permitiu, certamente, um avanço bem marcado dos controles sociais nessa região de 'perversidade'; mas também possibilitou a continuação de um discurso de 'reação': a homossexualidade pôs-se a falar por si mesma, e reivindicar sua legitimidade ou sua 'naturalidade' e muitas vezes dentro do vocabulário e com as categorias pelas quais era desqualificada do ponto de vista médico. Não existe um discurso do poder de um lado e, em face dele, um outro contraposto [...]. (FOUCAULT, 1979, p. 95 - 96) 
De acordo com Foucault (1979), estamos inevitavelmente emaranhados em uma malha de micro poderes, posicionados em relações estratégicas entre si. Embora não se possa pular para fora dessa rede, pode-se procurar efetuar mudanças no posicionamento estratégico dos poderes de acordo com nossos objetivos do momento. O próprio Foucault (1984), em entrevista concedida pouco antes de sua morte, reconheceu a importância da postura tradicional dos grupos homossexuais que, baseando-se na ideia de uma identidade de natureza "essencial" para si, têm-se concentrado nos aspectos de direitos civis, entendendo a liberação sexual em termos de simples tolerância sexual. (FOUCAULT, 1984) Ele afirma ser importante termos a possibilidade e o direito de escolher a nossa sexualidade, lembrando que os direitos humanos relacionados à sexualidade continuam a ser importantes e que nem sempre são respeitados. Porém seria necessário ir um passo além. Para consolidar os ganhos recentes da militância homossexual seria agora também necessário procurar criar novas formas de vida, de relacionamentos, de amizade, de arte, cultura etc., através das opções sexuais, éticas e políticas dos homossexuais. Os homossexuais teriam então não só que se defenderem, mas também se afirmarem tanto como identidade quanto como força criativa.

Não se trata aqui da simples criação de uma cultura homossexual e sim de uma cultura da qual o prazer faça parte. Ele nota que durante séculos as pessoas em geral, além dos médicos, psiquiatras e movimentos de liberação, sempre têm falado a respeito do desejo e não do prazer. Eles têm procurado liberar os seus desejos, enquanto Foucault (1984) acha que deveriam criar novos prazeres e esperar que o desejo viesse em seguida.

Continuando sua discussão a respeito de identidades que se formam em volta de novas práticas sexuais, ele afirma:

A identidade é útil enquanto for somente um jogo, um procedimento para manter relações sociais e de sexo/prazer que criam novas amizades. Mas se a identidade se torna o problema da nossa existência sexual e se as pessoas acham que eles devem "descobrir" a sua "identidade própria" e que esta deve se transformar na lei, no princípio e código de suas existências; se a sua questão perene for: "Será que isto está de acordo com minha identidade?", nesse caso eu acho que eles voltarão a um 
tipo de ética muito próxima da antiga virilidade heterossexual. Se nós tivermos que nos reportar à questão de identidade, terá que ser uma identidade da nossa pessoa única. Mas as relações que devemos manter conosco mesmos não são de identidade, mas sim de diferenciação, criação, inovação. É muito tedioso ser o mesmo. Não devemos excluir a identidade, se ela dá prazer às pessoas, mas não devemos concebê-la como uma regra universal. (FOUCAULT, 1984, p. 26)

Entre os estudiosos da obra foucaultiana a máxima “onde há poder há resistência" já se tornou lugar comum. Nessa entrevista ele concorda com a ideia de que a resistência não é só uma negação e sim um processo criativo. Embora dizer "não" às vezes seja da maior importância, resistir seria também um processo de recriar e de mudar. Mas, como a resistência nunca se encontra em posição de exterioridade em relação ao poder, ela sempre estará dependente da situação contra a qual ela luta. Desse modo, a definição médica da homossexualidade foi um instrumento muito importante na luta contra a intolerância no século passado e no início do atual. Durante o auge do movimento homossexual no Brasil (1979 e 1980) talvez se pudesse dizer que a ideia de uma "essência homossexual" também foi muito importante para a aglutinação de pessoas dispostas a levantar a questão. Posições que poderíamos chamar de "resistência criativa", como as de Fry (1982) e Bernardet (1982), seriam apropriadas a uma segunda fase, que se seguiria à consolidação de conquistas no terreno dos direitos civis. Sintomaticamente, seus artigos foram publicados em 1982, já aproveitando um espaço que talvez não estivesse tão aberto a esse tipo de discussão se não fosse por toda a militância desenvolvida pelos grupos homossexuais nos anos anteriores, onde eles mesmos tiveram um importante papel de pioneirismo e coragem, ao participarem do conselho editorial do jornal Lampião da esquina.

\section{Referências}

BERNARDET, J. C. Os homossexuais no momento de sua definição'. Folha de $S$. Paulo, São Paulo, jul. 1982. Folhetim, Suplemento. p. 9.

GALLAGHER, B.; WILSON, A. Michel Foucault, an interview: sex, power and the politics of identity. The Advocate, San Mateo, n. 400, p. 26-30, aug. 1984. 
FOUCAULT, M. História da sexualidade I: a vontade de saber. 2. ed. Rio de Janeiro: Graal, 1979.

FRY, P. Ser ou não ser homossexual, eis a questão. Folha de S. Paulo, São Paulo, jan. 1982. Folhetim, n. 3.

HOCQUENGHEM, G. A contestação homossexual. São Paulo: Brasiliense, 1980.

PADGUG, R. A. Sexual matters: on conceptualizing sexuality in history. Radical History Review, New York, v. 20, p. 3 - 23, 1979.

WEEKS, J. Discourse, desire and sexual deviance. Some problems in a history of homosexuality. In: PLUMMER, K. The making of the modem homosexual. 1. ed. Londres: Hutchinson, 1981. p. 76-111. 


\section{AIDS - Prevenção ou novo tipo de segregacionismo ${ }^{1}$}

O advento da epidemia de aids, que hoje já se configura em escala mundial, parece trazer em sua esteira o potencial para efetuar importantes mudanças sociais. Não será a primeira vez que o surgimento de uma nova doença causa alterações em grande escala tanto no comportamento individual quanto em termos políticos. Podemos lembrar, a este propósito, os efeitos devastadores do surgimento da sífilis durante o século XVI, que veio a alterar, em poucas décadas, as práticas sexuais em toda a Europa e, segundo alguns, teria sido um fator da mais alta importância para a consolidação política do puritanismo em vários países.

Hoje o espectro da aids ronda não só metrópoles do primeiro mundo, onde desde a década de 60 se vem desenrolando a chamada "revolução sexual", mas também regiões como a África Central, onde a sexualidade ainda é regida pelo mais arraigado tradicionalismo. Assim como a própria sexualidade é concebida e vivenciada de múltiplas maneiras inextricavelmente associadas às culturas e sociedades específicas, também as doenças adquirem seus significados culturalmente,

1 Comunicação apresentada no 3o Congresso Nacional de Sociologia, Brasília, DF, jul. 1987. 
e estes lhes emprestam uma diversidade de potenciais sociais e políticos. Essa noção fica exemplarmente ilustrada pelas diferentes características epidemiológicas da aids na África, onde seu alastramento se dá entre a população em geral, e nas Américas e Europa, onde atualmente permanece em grande parte confinada a certos chamados "grupos de risco" de contornos ainda bem definidos.

Portanto, ao discutirmos as implicações e consequências dessa doença, não podemos tratá-la como um simples dado da natureza, tomado isoladamente do seu contexto social e cultural específico. Propõe-se aqui um exame de suas manifestações no Brasil ou, mais especificamente, em São Paulo, embora não sejam descartadas referências e comparações a situações ocorrendo em outros países.

Não se pretende fazer um histórico detalhado do desenvolvimento da doença entre nós, sendo suficiente lembrar que ela começou a ser notificada no segundo semestre de 1982, quando surgiram seis casos, dos quais quatro foram a óbito, e a partir de então o número de casos notificados teve uma tendência a se duplicar a cada seis meses, tendo atingido o preocupante número de 238 somente nos primeiros três meses de 1987. A situação atual, no Estado de São Paulo, é a de um total de 1026 casos notificados, dos quais 387 já faleceram. Os principais fatores de risco encontrados são; homossexualidade masculina (54,94\% de casos), bissexualidade masculina (28,96\%), transfusão de sangue ou derivados $(3,93 \%)$, uso de drogas endovenosas não prescritas $(2,89 \%)$ e contato heterossexual de bissexual masculino $(1,35 \%)^{2}$. Revela-se, portanto, um quadro onde $83,90 \%$ dos doentes era adepto de práticas homossexuais, quer num contexto exclusivamente homossexual, quer numa alternância com a heterossexualidade. Repetia-se, assim, entre nós, a constatação americana de que a principal forma de transmissão da aids se dá através do contato homossexual masculino.

A chegada da aids ao Brasil coincidiu com um período em que a homossexualidade começava a ganhar grande visibilidade, principalmente devido ao boom do comércio voltado ao público gay, mas também em virtude das atividades de grupos engajados em uma militância

2 Fonte: Divisão de Hansenologia e Dermatologia Sanitária, Instituto de Saúde, Secretaria de Estado da Saúde de São Paulo, Centro de Referência Nacional para AIDS, março de 1987. 
política de defesa dos direitos civis dos homossexuais. Embora aqui as organizações gays, com fins comerciais ou políticos não tenham chegado a atingir a estrutura ou a solidez de suas congêneres americanas, elas já começavam a adquirir uma certa legitimidade social. À noite, grandes aglomerações se formavam nas calçadas, às portas de bares e boates voltados para o público gay. Saunas de equipamento sofisticado ofereciam a possibilidade de variadas práticas homossexuais em casal ou em grupo e as bancas de jornais estavam repletas de luxuosas publicações pornográficas, em sua maioria estrangeiras, dedicadas à exibição de corpos masculinos, nas quais eram comuns as cenas explícitas de sexo entre homens. É verdade que continuavam a ocorrer as ocasionais investidas policiais contra algumas das aglomerações de homossexuais em certas ruas do centro, e a repressão à prostituição de travestis assumia frequentemente características de brutalidade feroz, mas já se havia atingido uma tal legitimidade social que se tornava possível a grupos de homossexuais conseguirem longas audiências com autoridades como o secretário de Segurança para denunciar essas violências.

Em 1982, quando surgiram os primeiros casos de aids no Brasil, alguns antigos militantes do Movimento Homossexual ${ }^{3}$ reuniram-se em São Paulo com integrantes da recentemente eleita administração estadual peemedebista para externar suas preocupações, e a partir desse encontro procedeu-se à criação do Programa de Combate e Prevenção à AIDS, subordinada à Secretaria da Saúde. Algum tempo depois, estabelecia-se o Grupo de Apoio à Prevenção à aids (GAPA), independente de qualquer órgão oficial, formado por membros dos então chamados "grupos de risco" e simpatizantes, cuja preocupação era a de prestar assistência aos doentes e fiscalizar a atuação dos médicos, hospitais e demais autoridades ligadas à saúde pública.

3 Termo pelo qual é conhecido o conjunto de grupos militantes pelos direitos dos homossexuais. Esse movimento teve seu auge em 1980, quando chegou a contar com a participação de mais de vinte grupos espalhados por todo o Brasil. Atualmente, continuam ativos alguns grupos, como o Grupo Gay da Bahia (Salvador), Triângulo Rosa (Rio de Janeiro) e Grupo de Ação Lésbica-Feminista (São Paulo). 
Dada a letalidade e a impossibilidade de cura da doença, uma vez estabelecida no organismo, o seu longo período de latência, durante o qual o portador permanece sadio, embora talvez esteja espalhando a infecção e as formas ainda um tanto misteriosas de contágio, procurou-se desde o início enfatizar a questão da prevenção. Porém, deparava-se aí com um grande dilema sobre qual seria a abordagem preventiva mais eficaz: a recomendação de castidade, ou monogamia estrita, ou a sugestão de alterações específicas, que tornassem as práticas homossexuais menos perigosas.

Havia sérias dificuldades práticas e políticas na implementação da proposta de uma monogamia estrita, embora ela aparentasse indicar a maneira mais eficiente de reduzir o alastramento dessa síndrome. Afinal, atribuía-se à rápida difusão da aids ao elevado número de parceiros sexuais com os quais se alegava que os gays mantinham relações. Chegou-se até a divulgar, como típico, o exemplo de um indivíduo que dizia ter tido mil parceiros em um só ano. Embora estimativas dessa magnitude, extrapoladas para a população homossexual masculina como um todo, apresentassem um quadro exagerado, não há dúvida de que, entre esses indivíduos, a alternância constante de parceiros constitui-se, frequentemente, num fator não só de prazer, mas também de prestígio.

Talvez não seja exagero a afirmação de que essa promiscuidade, em muitos casos, é parte constitutiva da própria identidade gay. A propósito, cabe aqui um rápido parêntese para lembrar de que, atualmente, está muito difícil estabelecer qualquer tipo de "essência”, seja biológica, seja psicológica, que sirva para distinguir a priori um indivíduo adepto de práticas homossexuais. Ganha importância, portanto, a visão defendida aqui, segundo a qual a atribuição de uma identidade homossexual é uma questão melhor entendida do ponto de vista da sociologia ou da antropologia quando se desenvolve a teoria da rotulação social. (MCINTOSH, 1968) Basta lembrar que, apesar da ampla difusão das práticas homossexuais masculinas, tradicionalmente, no Brasil, o único estigmatizado como "anormal" tem sido o parceiro percebido como "passivo". Até hoje, por exemplo, a prostituição masculina, seja na sua forma "viril" (michês), seja na forma pseudofeminina (travesti), perpetua esse modelo. Só mais recentemente 
vem ganhando força uma concepção mais "democrática”, segundo a qual ambos os parceiros seriam igualmente "homossexuais". Tirando-se a ênfase dos detalhes das práticas - quem faz o quê - e dando-se toda a importância ao sexo fisiológico do parceiro -homem com mulher, ou homem com homem -, deixa-se de diferenciar os "ativos" dos "passivos", para se concentrar na identidade "heterossexual" ou "homossexual" do indivíduo. (FRY, 1982)

Mas essas identidades não são dadas a priori pela natureza e precisam ser socialmente construídas, variando de configuração de cultura, para cultura. (MACRAE, 1985) Quando, por uma razão ou outra, o indivíduo começa a se conceber como "homossexual", ele precisa passar por um período de aprendizagem para desenvolver esta nova identidade. Embora a cultura que envolve a todos e, no Brasil atual, projete uma infinidade de imagens do que significa ser homossexual, estas vêm, quase invariavelmente, acompanhadas de conotações negativas. O "gueto" torna-se, assim, uma das principais fontes de uma autovalorização mais positiva para esses indivíduos portadores de uma identidade estigmatizada, e isto é de grande importância para o seu equilíbrio e bem-estar psíquico.

Por "gueto" entende-se aqui um campo social formado principalmente por certos bares, boates, saunas, cinemas, ruas, praças e banheiros públicos onde, a certas horas do dia, converge um grande número de homossexuais. Lá se estabelecem redes de amizade, que podem vir a desempenhar funções importantes nas vidas de seus frequentadores, oferecendo, além de sociabilidade, oportunidades de trabalho, moradia, ajuda financeira e sexo. Porém, seria errado imaginar que os homossexuais chegam a constituir uma categoria social homogênea. Deve-se lembrar, de início, que nem todos são frequentadores do "gueto". O próprio "gueto" é bastante diversificado, existindo em seu seio divisões de classe, raça, idade, gênero, nível cultural etc. (PERLONGHER, 1987) Sem dúvida, o principal elo de ligação entre seus indivíduos é o seu interesse pelas práticas homossexuais e o seu desejo de compensar as estigmatizações sofridas na sociedade maior. Dessa forma, a chamada "caçação" ou "paquera" torna-se a grande razão de ser do "gueto" e o assunto dominante em todas as rodas de conversa que lá se formam. 
Apesar de seu comportamento sexual ser diferente daquele da maioria dos homens, os gays, em sua maior parte, foram criados com os mesmos valores que os seus equivalentes heterossexuais. Assim como eles, foram levados a acreditar que os homens tinham direito a uma grande liberdade sexual, sendo que muitos consideram que o seu prestígio pessoal depende do número de diferentes conquistas sexuais dos quais são capazes. Portanto, é de se esperar que um casal formado por dois homens quase inevitavelmente tenda a ser mais instável que um formado por indivíduos de ambos os sexos, já que os dois são inclinados a valorizar uma maior rotatividade de parceiros.

Outro fator enfraquecedor da monogamia homossexual é a falta de pressões sociais familiares, legais, econômicas etc., que servem para manter unidos os casais heterossexuais, mesmo depois de terminada a primeira paixão que os levou a se unirem inicialmente. A alternativa proposta por aqueles que recomendam a monogamia para a prevenção da aids é o celibato e a castidade. Apesar dos apelos que essas recomendações possam ter para quem gostaria de ver uma volta a um regime sexualmente mais repressivo, as mazelas psíquicas e sociais que acarretam já foram, por demais, demonstradas e discutidas para que as consideremos alternativas viáveis ou desejáveis.

Surge, então, um outro grupo de propostas que enfatiza o fato de que a aids não resulta diretamente do fato de se ter um grande número de parceiros, e sim de práticas específicas. Procura-se, portanto, difundir o conhecimento sobre certas técnicas que retirariam o perigo de contágio das relações sexuais, não importando com quantos parceiros diferentes se dessem. Recomenda-se, assim, usar a camisa-de-vênus e evitar a troca de fluidos orgânicos em geral. Essa abordagem mais positiva esbarra, porém, em muitos obstáculos. O maior deles é a concepção moralista que ainda comanda posições de grande poder dentro de nossa sociedade e que até agora tem tornado quase impossível uma discussão da sexualidade de forma ampla e isenta de preconceitos. A questão da homossexualidade em específico ainda é tratada como um tabu pelos meios de comunicação de maior difusão, apesar do grande interesse manifestado por este assunto pelo 
grande público. ${ }^{4}$ Quando abordado, o tema tem sido tratado de forma oblíqua e eufemística, ou então em tom caricatural e ridicularizador.

Imagine-se, dentro desse contexto, o escândalo provocado quando se pretende fazer recomendações detalhadas sobre como o indivíduo deve proceder para continuar a manter relações homossexuais com prazer e segurança. Obviamente, campanhas desse tipo dificilmente conseguem veiculação adequada e recebem pouquíssimo apoio. Nem mesmo os fabricantes de camisas-de-vênus se dispõem a alardear o seu uso como principal maneira de evitar o alastramento da aids. Tampouco existe muito interesse em realizar pesquisas com novos produtos, como preservativos de borracha resistente, mais apropriados ao coito anal, ou então o desenvolvimento de certos espermicidas com a capacidade de neutralizar o vírus propagador da síndrome. (ALTMAN, 1986) Os médicos também se mostram frequentemente incapazes, ou então indispostos, a atender uma clientela homossexual preocupada, mas desejosa de manter suas práticas sexuais, e raramente são capazes de fornecer recomendações detalhadas sobre como fazer isso, preferindo simplesmente apelar para um chamado à castidade ou à monogamia (heterossexual de preferência).

Outro obstáculo à adoção dessas normas, chamadas pelos americanos de safe sex, "sexo seguro", encontra-se entre a própria população homossexual masculina que, ao contrário dos heterossexuais, sempre preocupados com as possibilidades de gravidez, nunca se havia deparado com a necessidade de usar qualquer tipo de preservativo. Até recentemente, essa era até alardeada como uma das grandes vantagens da homossexualidade. Além disso, muitos homossexuais constroem sua identidade desviante em torno da noção de que seriam presas de um instinto ou desejo "selvagem", que não admite controles sociais e que, portanto, tem que ser obedecido, mesmo às custas do opróbrio da sociedade maior. Esses indivíduos, portanto, escudados atrás desse conceito de uma homossexualidade imposta pela natureza, recusam-se a abrir mão de práticas perigosas como o coito anal desprotegido e, frequentemente, repetem o velho chavão

4 Recentemente, a novela "Roda de fogo", transmitida pela Rede Globo, sofreu vários cortes da censura em cenas onde se discutia a homossexualidade de um dos personagens 
sobre o uso de preservativos ser a mesma coisa que "chupar bala sem tirar o papel".

A mudança dessas atitudes é dificultada ainda mais pela ausência no Brasil de um fórum para a discussão constante de questões relacionadas à homossexualidade. Diferentemente dos EUA, não se dispõe aqui de uma imprensa dirigida ao público gay e tampouco existem organizações que sejam reconhecidas como tendo qualquer legitimidade para falar por esse segmento da população. De fato, no Brasil, ainda está muito incipiente o conceito de "comunidade homossexual", o "gueto" sendo voltado quase exclusivamente ao lucro fácil e imediato. Ilustração disso é a dificuldade inicial de se conseguir que as saunas gays adotassem medidas que diminuissem os riscos a que seus clientes se expõem, seja através de campanhas educativas, seja através da eliminação de seus "quartos escuros", por exemplo.

As poucas iniciativas de esclarecimento a esse respeito têm sido enfraquecidas a tal ponto que chegam a perder quase toda a sua eficácia. O GAPA, por exemplo, lançou um cartaz explicativo como o título Transe numa boa, destinado exclusivamente à exposição em lugares de frequência homossexual, mas seus esforços, além de não receberem apoio público, foram violentamente criticados por importantes autoridades médicas, que o consideraram imoral e grosseiro. ${ }^{5}$

A própria campanha de esclarecimento lançada pelo Ministério da Saúde teve suas verbas severamente cortadas e alguns dos filmetes, originalmente planejados para explicar melhor as medidas preventivas possíveis, foram censurados e programados para ser exibidos pela televisão em um horário tardio e de baixa audiência. Justamente o público menos informado, ou seja, aquele mais carente de esclarecimentos é o menos atingido por uma campanha nesses moldes.

Mas o perigo apresentado pela aids tem sido amplamente divulgado por todos os meios de comunicação, embora geralmente de

$5 \bigcirc$ texto completo desse cartaz, concebido para ser exibido principalmente em saunas gays, era o seguinte; "Transe numa boa - Sexo é bom - Não deixe a AIDS acabar com isso - Evite contato com esperma - Use camisinha - Reduza o número de parceiros - Masturbação a dois é gostoso e oferece menos risco - Estar informado é a melhor prevenção - Plantão AIDS (011) 280-0770 - Grupo de Apoio à Prevenção à AIDS - Caixa Postal 4106, CEP 01051 SP". 
maneira moralista. Isso vem tendo repercussão não só nos meios gays, mas entre toda sociedade, e hoje tanto homossexuais quanto heterossexuais têm nesse mal uma nova razão para sua ansiedade em torno da questão sexual. $\mathrm{O}$ assunto parece dominar todas as conversas e existem indícios ainda incertos de certas mudanças de hábitos. Embora as velhas práticas perigosas continuem ocorrendo entre os homossexuais, parece haver uma nova consciência a respeito da importância do uso de preservativos e uma nova ênfase no voyeurismo e na masturbação, indicados pelo boom na pornografia, e pelo frenético movimento em alguns banheiros públicos, frequentados por homens que simplesmente desejam masturbar-se às vistas de outros, sem correr risco de contaminação pelo vírus da aids.

Apesar dessas práticas serem tradicionalmente as mais estigmatizadas e perseguidas, devido ao seu aspecto “público", face à nova ameaça à saúde da população, talvez seja a hora de repensar atitudes, priorizar a redução de riscos, adotar, em relação a algumas dessas práticas, uma política de vistas grossas, similar em espírito àquela adotada por certos países onde o alto índice de transmissão da aids através de agulhas contaminadas, levou as autoridades a liberarem a distribuição de seringas descartáveis entre a população dependente de drogas injetáveis.

Aqueles a quem repugnam esses tipos de concessões à "normalidade" de práticas que têm sido altamente estigmatizadas, preferem adotar outra abordagem preventiva, caracteristicamente de maior potencial repressivo, mas que também oferece a possibilidade de grandes lucros para algumas indústrias. É a proposta do uso rotineiro e massivo do teste anti-HIV, erroneamente considerado pelos leigos como o "teste da aids".

Registrar a presença do vírus HIV, ao qual atualmente se costuma atribuir a causa única da aids, é uma operação difícil e cara. Os testes sanguíneos geralmente aplicados partem do princípio de que a infecção pelo vírus HIV - também chamado HTLV3 - instaura no organismo uma produção incessante de anticorpos específicos destinados a combatê-lo. Para fins de detecção, funciona como sinalizador da passagem do vírus, uma vez que ainda não existem testes economicamente viáveis que acusem diretamente a presença do HIV no corpo de um indivíduo. 
Porém, isso não é geralmente considerado como suficiente em si para diagnosticar a aids, conforme parecer da própria Organização Mundial da Saúde. Para tanto, além de uma série de outros testes, torna-se imprescindível um exame clínico que comprove a presença de sintomas associados à síndrome.

O real significado da presença do anticorpo no organismo ainda não foi plenamente esclarecido. Atualmente, acredita-se que entre $15 \%$ e $30 \%$ dos seus portadores - aqui chamados de "soropositivos" desenvolverão a doença. Também não se sabe ao certo qual percentagem dos soropositivos são transmissores sadios do vírus, embora possivelmente a maioria o seja.

Além de não se ter certeza do significado da presença desse anticorpo num organismo, o teste mais comumente usado, o ELISA, tem a desvantagem de ser pouco preciso e de falhar com frequência, apresentando uma considerável proporção de falsos resultados, tanto negativos quanto positivos. Por isso, normalmente, recomenda-se que seu resultado seja confirmado por outro teste mais caro e mais confiável, mas também não infalível, como o chamado "Western Blot", por exemplo.

Esses métodos têm sido geralmente considerados como apropriados para o controle da qualidade de lotes de sangue a ser usado em transfusões, medicamentos para hemofílicos etc. Nesses casos, havendo alguma dúvida, deve-se optar simplesmente pela não utilização do sangue soropositivo. Em se lidando com seres humanos, a questão torna-se muito mais complexa, pois não se pode retirar uma pessoa do convívio normal da sociedade só "por via das dúvidas".

Apesar disso, certos médicos e autoridades sanitárias, sentindo a necessidade de "mostrar serviço", mesmo que ineficazmente, frente a um público tomado pelo pânico, têm argumentado em favor da aplicação rotineira desses testes na população em geral. Ao seu lado se colocam os agentes de indústrias farmacêuticas, fascinados pela perspectiva de um novo mercado milionário, e representantes de outras organizações que almejam impor a todos suas concepções de vida fundadas num moralismo autoritário e obscurantista.

No contexto atual, essa política pode ter resultados catastróficos. No plano individual, devem-se levar em conta os problemas de ordem 
psíquica enfrentados por quem é declarado soropositivo - muitos já enlouqueceram ou se suicidaram, frequentemente até devido a um resultado falso-positivo. No plano social, deve-se atentar para o perigo de se criar uma nova categoria de cidadãos de segunda classe, que passam a ser discriminados no emprego, na obtenção de seguros, moradia, e até na simples convivência social. Até trabalhadores da saúde, que deveriam estar cientes do baixo perigo de contágio apresentado pela aids, sucumbem ao irracionalismo e frequentemente recusam-se a tratar de pacientes soropositivos.

Quando se lembra o marcado recrudescimento do autoritarismo na sociedade brasileira e a inevitável marginalização social de parcelas cada vez maiores da população, decorrentes da atual contração da economia, o receio da concretização de um novo tipo de racismo deixa de parecer exagerado.

Já existe no Brasil um sistema público de controle da saúde bastante desenvolvido e geralmente legitimado como "progressista". Isso predispõe a população a aceitar a aplicação em massa de vários tipos de vacinas e testes médico-psicológicos, mesmo na ausência de legislação ordinária estabelecendo claramente sua obrigatoriedade. Profecias apocalípticas semeiam um clima de pânico, que contribui para a adoção de medidas autoritárias com justificativas "sanitaristas”. Neste ponto, a infame política, só abandonada no Brasil há poucas décadas, de internar compulsoriamente os portadores de hanseníase em leprosários, deve nos servir de aviso para possíveis desenvolvimentos futuros.

Apesar do absurdo implícito nessa política, vários países, como os EUA, Japão, Alemanha, Bélgica e Arábia Saudita, já planejam a aplicação massiva do teste anti-HIV. No Brasil, o exército está entre aqueles que propõem a sua obrigatoriedade para turistas e estrangeiros e, atualmente, transita pela Assembleia Legislativa de São Paulo um projeto de autoria do deputado João do Pulo, que se sujeitaria a ele qualquer candidato a cargo ou vaga em instituições públicas. Numerosas empresas privadas já o aplicam clandestinamente em seus funcionários ou em candidatos a emprego. Atualmente, cogita-se também em realizá-lo entre a população carcerária, embora ninguém tenha sugestões concretas a respeito do que fazer com os numerosíssimos 
detentos que, a partir daí, serão rotulados como "portadores sãos". A magnitude do problema que isso criará pode ser aferida a partir do fato de que, atualmente, esses indivíduos são erroneamente considerados como "aidéticos" tanto pelos guardas quanto pelos outros presos e são alvo constante de ameaças de morte, devido ao medo de contágio que inspiram.

A magnitude dos problemas apresentados pela aids é difícil de calcular. Nos EUA já existem atualmente mais de 33.000 casos notificados, o suficiente para que até o sistema hospitalar desse país, o mais rico do mundo, comece a dar sinais de ser incapaz de lidar com tantos pacientes de um mal cujo tratamento é dos mais caros. No Brasil já havia, em abril de 1987, 1.542 casos notificados. (PERLONGHER, 1987) Levando-se em conta o alto índice de subnotificação e a extrapolação normalmente feita de que, para cada indivíduo manifestando sintomas da doença, existem cem outros que estiveram expostos ao vírus, com boas chances de o disseminarem e de também vir a adoecer, é lícito prever, para daqui a pouco tempo, uma situação de catástrofe sanitária no país, semelhante à que ocorre em certos países africanos, onde enormes proporções da população em geral já se encontram infectadas ou doentes. As consequências sócio-políticas disso, no atual quadro brasileiro de crise generalizada, podem vir a ser gravíssimas.

Portanto, é preciso formar urgentemente uma corrente de opinião que busque formas não repressivas de prevenção à aids, basicamente através de campanhas educativas e da triagem cuidadosa do sangue doado. Deve-se atentar para que a atual crise de saúde não sirva de pretexto para aqueles que, sem se incomodar com os direitos civis da população, procuram constituir novas formas de estigmatização e segregação.

\section{Referências}

ALTMAN, D. AIDS and the newpuritanism. London: Pluto Press, 1986.

FRY, P. Da hierarquia à igualdade: a construção da homossexualidade no Brasil. In: FRY, P. Para inglês ver: identidade e política na cultura brasileira. Rio de Janeiro: Zahar, 1982. p. 87-115. 
MACRAE, E. O Militante Homossexual no Brasil da Abertura. 1985. 218 f. Tese (Doutorado em antropologia) - Faculdade de Filosofia, Letras e Ciências Humanas, Universidade de São Paulo, São Paulo, 1985.

MCINTOSH, M. The homosexual role. Society for the study of Social Problems, Estados Unidos, v. 16, n. 2, p. 182-192, 1968.

PERLONGHER, N. O negócio do michê: prostituição viril em São Paulo. São Paulo: Brasiliense, 1987. 


\section{PARTE II A construção da igualdade}




\section{A contestação cultural e a "abertura democrática"}

No final da década de 70, o Brasil começava a respirar ares mais otimistas. Para muitos, estávamos no limiar de novos tempos, mais justos e mais humanos. Grandes transformações se anunciavam como indicação do encerramento da vigência de uma ditadura férrea e sanguinária, e a sociedade civil ressurgia politicamente com importantes manifestações de protestos de trabalhadores, empresários, intelectuais e estudantes.

Em maio de 1978, a greve dos metalúrgicos do $\mathrm{ABC}$ dava início a uma vigorosa demonstração de força do movimento operário, que logo se estenderia a numerosas outras categorias e levaria dois anos para ser controlado. Como disseram os sociólogos Sebastião C. V. Cruz e Carlos E. Martins sobre esse período: “com a greve do $\mathrm{ABC}$ e o movimento que ele precipita abre-se um espaço enorme no campo das ideias e no imaginário político. Súbito, o possível dilata-se, o novo começa a brotar". (CRUZ; MARTINS, 1983, p. 59) A política salarial e a lei de greve, colunas mestras do regime pós 1964, caíram por terra. O governo parecia disposto a abdicar da tutela que exercia sobre a relação entre empresários e empregados. Pouco tempo depois, surgia a ideia da formação de um partido de trabalhadores. 
Em junho desse mesmo ano, alguns dias depois de revogar a censura prévia nas últimas publicações por ela atingidas, o presidente Geisel anunciou o anteprojeto de novas reformas para suprimir os instrumentos mais nitidamente discricionários da draconiana legislação em vigor, cuidando, porém, de não enfraquecer efetivamente as forças que o sustentavam.

Mantendo-se no mesmo espírito de cautela, o general Figueiredo, ao tomar posse como presidente da república em 1979, apresentou-se como o continuador desse processo de "distensão política", contando com o apoio do grande capital. Atendendo às pressões que se faziam em nível nacional, promoveu, neste mesmo ano, a anistia parcial e restrita, inicialmente, àqueles que não haviam participado de "crimes de sangue”, estendendo-a, posteriormente, a todos os prisioneiros e exilados políticos. Ao anistiar os tradicionais opositores do regime, essa lei servia também como forma de perdão a todos os atos de brutalidade e arbitrariedade, perpetrados pelos próprios agentes oficiais de repressão. Embora carregada de ambiguidades, a nova "abertura política” entusiasmou a sociedade. Depois de anos de sufoco, a vida cultural do país fervilhava e muitos acreditavam que estivéssemos à beira de realizar grandes mudanças socioculturais. A imaginação sentia-se prestes a ganhar o poder.

A própria contestação foi afetada pelo espírito de inovação. Os longos anos de ditadura haviam promovido uma crise na intelectualidade, semeando a inquietação e a dúvida a respeito das concepções políticas tradicionais. Discursos sobre o povo, suas dificuldades e suas lutas não resolviam mais os anseios, nem daqueles que haviam recusado, desde o início, o conformismo bem remunerado do "milagre econômico" e nem dos que se sentiram logrados, quando esse se desfez como uma bolha de sabão. Na busca de soluções para suas próprias contradições, estudantes e intelectuais voltavam suas preocupações para questões como: o corpo, o erotismo, a subversão de valores e de comportamentos. Buscavam inspiração nos movimentos, já antigos, da contracultura, vindos da Inglaterra e dos EUA. As discussões passaram a ser feitas em torno de assuntos como o uso de drogas, a psicanálise, o corpo, o rock, os circuitos alternativos, jornais underground, discos piratas, etc. Entre esses setores, começava a se tomar cada vez mais nítido um desencanto 
pela política, como ela vinha sendo entendida até então. A teoria e a prática das esquerdas eram questionadas, criticando-se também seu conservadorismo cultural, refletido na sua dificuldade em inovar nas áreas das artes e dos costumes.

O marxismo ficava estigmatizado como "caretice" e difundia-se uma nova noção: não existiria a possibilidade de uma revolução ou transformação social, sem que ocorresse também uma revolução ou transformação individual. Paralelamente ao decréscimo na participação política, ocorria um aumento no uso de drogas, como a maconha e o LSD, refletindo essa nova tendência introspectiva. Mas não se deve caracterizar esse fenômeno conhecido pelo nome de contracultura como uma simples acomodação ao sistema e um abandono dos antigos ideais de contestação. Afinal, para a política de esquerda o uso de drogas também era visto como uma contestação ao status quo, sujeito a uma repressão severa. Como diz Heloísa B. de Hollanda:

A marginalidade é tomada não como saída alternativa, mas no sentido de ameaça ao sistema: ela é valorizada exatamente como opção de violência, em suas possibilidades de agressão e transgressão. A contestação é assumida conscientemente. O uso de tóxicos, a bissexualidade, o comportamento descolonizado, são vividos e sentidos como gestos, perigosos, ilegais, e, portanto, assumidos como contestação de caráter político. (HOLLANDA, 1980, p. 68)

A juventude de classe média, marginalizada dos processos políticos brasileiros, voltava a sua atenção para os jovens dos grandes centros urbanos dos EUA e Europa, como Nova York e Londres, valorizando especialmente seus aspectos subterrâneos (underground) como o gueto negro do Harlem, a maconha, o LSD, o rock, e os Hell's Angels. Nos EUA, essa juventude não se identificava especialmente com o proletariado que, em sua maioria, se apresentava como racista e reacionário, apoiando, por exemplo, a atuação americana no Vietnã. Seu interesse maior era pelos outsiders (marginais). Lembremos que o final da década de 60 havia presenciado, nos EUA, as grandes explosões dos guetos negros, como Watts, em que a população marginalizada parecia, repentinamente, renegar todos os valores tradicionais do capitalismo partindo para saques e incêndios. Difundia-se, entre os jovens, a ideia 
de que a sociedade mais rica e poderosa do mundo estaria prestes a ser destruída, corroída por sua podridão interna. Procurando os equivalentes, brasileiros, identificavam as nossas minorias marginais como sendo aquelas constituídas pelos negros, homossexuais, freaks, favelados, adeptos da cultura afro-brasileira etc. Recusando os ideais de ascensão social burguesa, muitos deixavam seus estudos e empregos, procurando sobreviver do trabalho artesanal ou artístico. Alguns tentavam implantar comunidades rurais, enquanto outros, influenciados pelos tropicalistas, escolhiam a aldeia de Arempebe, na Bahia, como um lugar onde poderiam realizar sua utopia de paz e amor.

Na segunda metade da década de 70, quando tornou-se possível uma retomada do movimento estudantil, esses novos valores da juventude não deixaram de se manifestar, provocando alterações no ideário e na conduta da militância política. Surgia, assim, o germe de uma crítica à esquerda tradicional que, até então, mantivera uma posição quase hegemônica no movimento estudantil, sem se empenhar nos processos de transformação cultural que começavam a empolgar amplos setores da juventude. Entre os anos de 1976 e 1977, sobressaía-se, especialmente, um grupo de inspiração trotskista - a Liberdade e Luta (Libelú). Esse movimento, com suas palavras de ordem ousadas e uma maior abertura para os temas vinculados pela contracultura, captou a imaginação de muitos estudantes. Porém, no refluxo que se seguiu à primeira euforia de reorganização, correntes da esquerda mais ortodoxa conseguiram impor-se, deslocando a Libelú da liderança estudantil. Tornou-se, então, bastante óbvio que a unidade das esquerdas já não existia mais. Começaram a surgir críticas públicas de uma tendência a outra. Entre a massa dos estudantes, dizia-se que alguns grupos eram motivados por um desejo pelo poder em si; as assembleias estudantis eram acusadas de tediosas e de serem lugares em que a dominação de pequenos grupos era imposta em nome da unidade. O jornal Avesso, vinculado ao DCE-Livre da Universidade de São Paulo (USP), publicava, por exemplo, na sua edição de inverno de 1977, um artigo assinado por Andrés Stearns de Oliveira, criticando violentamente o conservadorismo dos métodos usados pelo movimento estudantil e o desejo de poder de suas lideranças. Nele, as assembleias estudantis são acusadas de serem "chatas" e os líderes considerados como porta-vozes de 
uma ideologia pré-histórica, como persistindo no costume de usar a noção de disciplina para melhor poder manipular a massa, recusando-se a aceitar quaisquer diferenças individuais.

E como acreditar na eficácia desse absoluto apodrecido que ainda hoje se repete, dessa suposta doutrina revolucionária! Não basta acabar com a exploração (se é que mesmo isso ela faz), é preciso acabar também com o poder onde quer que ele se exerça[...]. E de passagem é preciso falar desse último e mais escandaloso exército autoritário - algo que fede muito [...] a unidade [...] (ela) é totalitária já em si: é homogeneização, padronização, silenciamento das diferenças, repressão às individualidades. A mediocridade, o meio termo impera, não há outro, é a imposição do mesmo. O outro deve ser banido porque divide. (OLIVEIRA apud COELHO, 1984, p. 30)

Nesse artigo, já se encontravam temas que iriam ser retomados frequentemente por novos movimentos, como o homossexual e o feminista entre outros. Repelia-se o poder, entendido de forma genérica e passível de condenação, em todas as ocasiões quando uma manifestação era percebida, seja na forma institucional dos órgãos do Estado ou da estrutura dos partidos políticos, seja nas relações cotidianas entre indivíduos, como nas relações de pais e filhos, professores e alunos, patrões e empregados, cônjuges, amantes, etc. Contra os ditames do poder, erigia-se o prazer individual como o grande bem. Onde quer que ele estivesse ausente, via-se a vigência do autoritarismo, também chamado de fascismo, racismo, machismo, quase indiscriminadamente. Portanto, era grave a acusação de que as reuniões do movimento estudantil haviam se tornado tediosas.

O hedonismo individualista é um dos grandes valores promovidos pela moderna sociedade de consumo. Nem por isso, pode-se considerar essencialmente conservador seu significado maior, dependendo esse do contexto. Como já foi sugerido, uma forma importante de contestação cultural ocorria no âmbito da sexualidade e do questionamento dos papéis sexuais tradicionais. A total desvinculação entre a sexualidade e a procriação possibilitada pelo advento da pílula anticoncepcional, aliada a uma crescente contestação da moral até então vigente e uma maior complacência familiar, tornava a vida sexual dos jovens brasileiros mais aberta e livre. 
Dentro deste quadro, entende-se melhor a força das críticas aos esquerdistas ortodoxos, cujo moralismo irritava muitos jovens e estudantes. Sob pretexto de evitar chocar algum hipotético simpatizante proletário, as lideranças frequentemente se colocavam contra várias práticas bastante generalizadas entre a juventude. Nessa época, em que era bastante comum o relacionamento sexual descompromissado entre estudantes, eles ainda costumavam insistir no casamento formal de seus companheiros de militância. A homossexualidade era perseguida de forma mais veemente ainda, levando à defecção de muitos militantes, alguns dos quais iriam, mais tarde, engrossar as fileiras do movimento homossexual. Também criticavam duramente o uso da maconha e qualquer outro "tóxico" e estigmatizavam o rock, o soul, o funk, assim como outras influências estrangeiras, rotulando-as de "alienantes".

\section{O movimento das "minorias"}

A pesquisa de campo sobre o "Grupo Somos de Afirmação Homossexual" apresentada neste livro foi concebida em 1978 e se estendeu de forma sistemática até o segundo semestre de 1980. Além de um esboço sobre o clima político e cultural da época, torna-se útil expor com um pouco mais de detalhes o desenvolvimento de dois movimentos muito próximos e similares a ele que viriam a desempenhar um papel importante em sua história.

Com a nova liberalização política trazendo a possibilidade (ainda não oficializada) de um funcionamento mais às claras das várias organizações clandestinas de esquerda e com o livre debate de ideias propiciado pelo fim da censura à imprensa, o ideal de uma unidade das oposições mostrava-se cada vez mais inviável. Além do ressurgimento das divisões clássicas entre os marxistas, começavam a aparecer, também, novos grupos com reivindicações específicas de certas parcelas da população. Destacavam-se especialmente o movimento negro e o feminista, cujas problemáticas e métodos de ação eram voltados não só para as questões classicamente aceitas como políticas, mas também se ocupavam daquelas consideradas culturais ou relacionadas às experiências do dia a dia dos militantes: relações hierárquicas entre 
as raças, entre os homens e mulheres e, até, entre os líderes políticos e seus comandados dentro das próprias organizações contestatórias.

Tanto os negros quanto as mulheres ${ }^{1}$ tinham uma longa história de lutas que, no passado, visavam assegurar os direitos plenos de cidadania que lhes eram sistematicamente negados. Porém, por uma série de razões, nos anos pós-guerra e especialmente depois de 1964, essas campanhas se arrefeceram e suas lutas foram ignoradas, não só pela elite no poder como pelos próprios grupos oposicionistas. As transformações ocorridas na sociedade, a partir da década de 1970, fizeram com que os negros e mulheres retomassem velhas reivindicações e levantassem novas exigências. Encontrando pouco respaldo, entre os grupos políticos constituídos, e até certa má vontade, por parte de alguns esquerdistas que achavam secundárias suas lutas, eles passaram a elaborar, com autonomia, novas teorias e novos esquemas de atuação. Devido aos aspectos em comum entre suas organizações, negros e mulheres se tornariam interlocutores e aliados privilegiados dos grupos de militância homossexual que, como eles, não viam, no seu status minoritário, motivo para o desmerecimento de suas reivindicações específicas, voltadas aos seus problemas imediatos.

Embora os negros tivessem no Brasil uma longa história de organização, de luta e de reivindicação, além de terem criado vários órgãos de imprensa dedicados às discussões pertinentes à condição negra, o golpe de 1964 havia desarticulado as suas lideranças. Essas, segundo conta Gonzales (1982), foram lançadas numa semiclandestinidade, com pouco contato com as organizações clandestinas e de luta armada. Assim, durante algum tempo, deixou-se de falar de política negra.

As notícias da luta pelos direitos civis dos negros americanos e sobre as guerras de libertação nas colônias africanas de Portugal

1 Os movimentos negro e feminista são incluídos aqui entre os "movimentos de minorias" apesar de se saber que, no Brasil, há mais mulheres do que homens e que os descendentes de povos africanos são mais numerosos que os de cor branca, de ascendência puramente caucasiana. O termo "minoria" é adotado por ser essa a prática costumeira no Brasil, na época, e por apontar para o fato de que suas lutas se voltam preferencialmente para a meIhoria das condições de existência de segmentos especificos da sociedade, mais do que às da população como um todo. Além disso, a "minoridade" desses grupos seria um reflexo da discriminação sistemática que sofrem, o que lhes veda o acesso a um poder político-econômico mais compativel com seus números 
começaram a despertar o interesse de uma parcela da juventude negra. Nos primeiros anos da década de 1970, ocorreram várias manifestações de interesse pela cultura negra, muitas vezes vinculadas a instituições acadêmicas. Foram realizadas exposições de arte afro-brasileira, festivais de dança e música, seminários, cursos e palestras sobre o assunto em várias ocasiões. Por outro lado, nas grandes cidades, um interesse pela música negra norte-americana começava a contagiar os jovens e, numa aparente imitação dos modelos americanos, surgiam estilos de roupa, de corte de cabelo e de dança. Inicialmente no Rio, mas depois em várias outras grandes cidades brasileiras, promoviam-se grandes bailes onde jovens negros, das mais diversas posições sociais, se reuniam para ouvir e dançar a soul music. Essa ênfase na música americana provocava sérias críticas da parte de intelectuais mais ortodoxos que viam nisso sinais de alienação e convocavam os negros a se limitarem a dançar ritmos considerados "brasileiros", como o samba. Mas, apesar dessa crítica, o costume servia, inegavelmente, para incentivar uma consciência e a afirmação de identidade negra por parte dessa juventude. Concomitantemente, outros negros procuravam organizar, de forma mais explícita, um movimento político, desenvolvendo uma série de encontros em várias cidades do Brasil, buscando montar uma grande campanha contra o racismo.

No dia 7 de julho de 1978, foi assinalada a fundação do Movimento Unificado Contra a Discriminação Racial através de um ato público realizado nas escadarias do Teatro Municipal de São Paulo. Na ocasião, foi distribuída uma carta aberta à população anunciando uma campanha contra a discriminação racial, a opressão policial, o desemprego, o subemprego e a marginalização. A carta propunha, como forma de organização, a criação de "centros de luta" nos bairros, nas vilas, nas prisões, nos terreiros de candomblé e umbanda, nos locais de trabalho, nas escolas de samba, nas igrejas e em todos os lugares onde o negro vivia. A função desses "centros de luta" seria a promoção de debates, informação, conscientização e organização da comunidade negra, visando tornar o movimento forte, ativo e combatente, para levar o negro a participar de todos os setores da sociedade brasileira. O documento terminava pedindo o apoio dos setores democráticos da sociedade e com palavras de ordem contra a discriminação racial, 
a opressão policial, pela ampliação do movimento e por uma autêntica democracia racial.

Mas as aspirações pela unificação do movimento e pelo apoio dos demais democratas brasileiros logo se frustraram. Além de serem considerados racistas às avessas ou subversivos, pelos brancos poderosos, eles também foram atacados por alguns setores da esquer$\mathrm{da}$, que os consideravam divisionistas e revanchistas. Internamente, a situação não era melhor e desavenças, de fundo político e pessoal, logo desencadearam uma série de cisões.

Uma das dificuldades internas enfrentadas pelo movimento foi a acusação feita por várias de suas integrantes mulheres a respeito do machismo dos negros. Assim, durante um congresso realizado no Rio de Janeiro em dezembro de 1979, as mulheres denunciaram tentativas de branqueamento do homem negro através do casamento com mulheres brancas, discutiram problemas relativos à educação dos filhos, o controle da natalidade e a sua participação no processo de libertação do povo negro. Analisaram,também, a situação da mulher negra, enquanto empregada doméstica, na reprodução do racismo, não poupando críticas à atuação de muitas patroas brancas, militantes no movimento de mulheres.

Essa reunião, idealizada para discutir os problemas das mulheres negras, contou também com a participação de um militante baiano que chamou atenção à discriminação específica sofrida pelos negros homossexuais como ele, apontando semelhanças entre os problemas enfrentados pelos gays e pelas mulheres. Dessa forma, começava a discussão da sexualidade dentro do recentemente constituído movimento negro. Esse, alguns meses depois, passaria a contar com um novo grupo de Salvador, integrado exclusivamente por negros homossexuais, o Adé Dudu.

A reunião à parte e a elaboração de uma série de reivindicações específicas pelas militantes negras presentes nesse congresso eram também reflexo de uma outra ideia que estava então ganhando espaço: o feminismo. Esse começara a se desenvolver no Brasil, a partir da decretação pela ONU do ano de 1975 como o Ano Internacional da Mulher, com a consequente abertura aqui de um importante espaço de debate político, quando ainda predominava a repressão violenta 
contra qualquer tipo de questionamento da ordem vigente. A partir daí, começaram a se formar vários grupos de mulheres, para discutir a sua situação social, política e cultural, lançando assim as sementes do movimento feminista.

Em dezembro de 1975, para comemorar o Ano Internacional da $\mathrm{Mu}$ lher, o grupo carioca Centro da Mulher Brasileira lançou o número zero de um novo jornal, de formato tabloide, chamado Brasil Mulher, onde se dava amplo destaque ao trabalho de Terezinha Zerbini e ao Movimento Feminino pela Anistia (MFA), promovido por ela. Esse movimento colaborou, durante algum tempo, com a organização de mulheres e serviu como trampolim para várias de suas militantes travarem contato com o feminismo. Isso apesar da própria Terezinha Zerbini sempre ter se mantido numa posição contrária a essa tendência e do MFA ter deixado a frente unitária de mulheres em São Paulo em 1978, quando a maioria dos grupos participantes optou por incluir a questão do aborto entre suas bandeiras de luta.

Em junho de 1976, foi lançado em São Paulo o jornal Nós mulheres, a primeira publicação brasileira contemporânea a se declarar feminista. Já no seu primeiro editorial afirmava-se: "somos oprimidas porque somos mulheres", denunciando-se a dupla moral e a repressão sexual. Também eram feitas algumas formulações teóricas que, mais tarde, teriam grande importância no movimento feminista. Tocava-se na questão dos papéis sexuais e da redução naturalista da mulher às funções de mãe e esposa. Enfatizava-se a importância e o caráter de trabalho necessário da sua atuação e da reprodução da família. Levantava-se a bandeira de "salário igual por trabalho igual" e pela socialização do salário doméstico. Embora essa fosse uma posição que seria abandonada posteriormente, esse editorial mostrava um forte comprometimento com a dialética materialista e, além de enfatizar a necessidade de profundas transformações sociais, insistia na ligação entre a luta feminista e a luta geral. (MORAES, 1981, p. 214)

O grupo que editava o jornal contava com uma forte influência de mulheres com experiência de exílio ou de estadias no exterior, onde haviam conhecido a moderna literatura feminista. Maria Moraes até afirma que o Grupo de Brasileiras no Exterior foi uma das matrizes mais importantes dos grupos feministas que viriam ser formados no Brasil. 
Esse primeiro editorial também fazia referências à luta da imprensa democrática e, de fato, o Nós Mulheres iria contar com um valioso auxílio por parte da imprensa alternativa. Mas a forma de organização dessas mulheres se diferenciava bastante da maneira comum nos grupos esquerdistas, que, nessa época, as consideravam "independentes demais". Não tinham uma disciplina rígida e se posicionavam contra hierarquias. Havia uma grande valorização do trabalho comunitário e as matérias eram todas discutidas em comum, não levando nenhuma assinatura. Esse método anárquico-artesanal era diferente do utilizado pelo Brasil Mulher, que sempre esteve mais próximo das normas vigentes na imprensa alternativa. Além de prenunciar as futuras discordâncias que surgiriam entre essas publicações, esse método também serviu para inaugurar no país um novo estilo de militância que depois seria adotado por outros grupos libertários, inclusive os dos homossexuais.

Como era de se esperar, devido às suas origens nas organizações esquerdistas, os grupos feministas passaram por uma fase inicial dominada por discussões sobre a conjuntura socioeconômica, buscando um entendimento da condição feminina dentro desse contexto mais geral. Mas, aos poucos, alguns desses grupos começaram a voltar suas atenções também às dificuldades que suas militantes sofriam enquanto mulheres de classe média. Surgiam, então, discussões em torno de temas existenciais como: relações familiares, expectativas frustradas, sensualidade, aborto, afetividade, violência, etc. Em torno dessas discussões foram estruturados "grupos de reflexão", nos quais as participantes faziam relatos sobre suas experiências pessoais para servirem de embasamento às considerações mais teóricas e generalizantes sobre a questão dos papéis de gênero. Esses grupos acabaram por levar ao estabelecimento de novas prioridades de luta e se tornaram uma importante característica que servia para diferenciar esses grupos "feministas" autônomos, dos "femininos", geralmente ligados a partidos políticos e sindicatos, voltando-se mais a questões gerais como a anistia, salários, custo de vida, etc.

Em pouco tempo, começaram a se manifestar atritos entre as "femininas" e as "feministas", estas acusadas de serem burguesas e partidárias de uma radical "luta contra o homem". 
Essas desavenças mostraram-se especialmente exacerbadas durante os Congressos da Mulher Paulista, realizados em março de 1979 e 1980. O primeiro congresso (1979) sofreu acusações de que técnicas de "cupulismo" e "conchavo" haviam sido usadas para impedir a divulgação de críticas às posições femininas ortodoxas. Em 1980, o segundo congresso, que contou com três mil participantes, foi palco de agressões físicas e roubos de crachás de delegada por parte de algumas militantes femininas. O clima ficou tão agressivo que o congresso terminou sem qualquer resolução e só veio a ser encerrado formalmente alguns dias depois em uma reunião de sua coordenadoria. A luta pelo poder, concebida pelos partidários desse novo estilo de militância como um vício endêmico entre os grupos de esquerda, não deixava de estar presente também nessas reuniões de mulheres.

Várias eram as causas das divergências surgidas no seio do movimento feminista: iam desde dificuldades atribuídas à dupla militância de algumas mulheres, que participavam de grupos feministas ao mesmo tempo em que se engajavam na luta político-partidária, até problemas de ordem puramente afetiva - como casos amorosos em que uma acusava a outra de lhe roubar o companheiro. Além disso, mesmo dentro dos diversos grupos feministas havia diferenças de opinião, a respeito do peso a ser dado às questões de política geral e às de ordem mais individual.

Os grupos feministas tiveram uma função importante em elaborar um discurso novo no Brasil sobre a sensualidade feminina e as questões da contracepção e do aborto. O direito à livre disposição do corpo tornou-se uma das suas principais reivindicações e as levou a se chocarem frontalmente com os grupos de esquerda tradicional, que, dependendo para a sua sustentação política de alianças com a poderosa Igreja Católica, tornavam-se, em muitos casos, defensores de posições conservadoras e machistas, mais compatíveis com a doutrina religiosa de moral sexual.

Além das questões da contracepção e do aborto, os grupos feministas também enfatizaram a questão do direito da mulher ao prazer sexual. Criada para ser mãe dedicada e dona de casa submissa ao marido, a mulher brasileira tradicionalmente aceitava a dupla moral, mantendo-se confinada ao lar, longe das “tentações da rua", e sempre 
permitiu ao homem uma atividade sexual intensa, geralmente com "mulheres da vida". Isso começava, agora, a ser questionado e grupos feministas iniciavam programas de esclarecimento sexual junto às mulheres dos bairros populares, onde, além de explicar o funcionamento dos órgãos sexuais, fomentavam discussões sobre a natureza das relações sociais e afetivas, travadas entre homens e mulheres.

Estes relatos, necessariamente esquemáticos e parciais sobre os movimentos negro e feminista, demonstram uma tendência que, embora difusa pela sociedade em geral, se manifestava com mais intensidade entre a esquerda. Consistia na revalorização de problemáticas mais específicas a certos setores, cujos problemas vinham sendo, até então, relegados a posições secundárias, pelos partidários de uma concepção política voltada exclusivamente para a luta de classes. $\mathrm{O}$ movimento negro, ao enfatizar a opressão suplementar sofrida pelo trabalhador de origem africana, rompia com a ideia de uma grande classe operária unida pela mesma exploração capitalista. O movimento feminista, por seu lado, servia para chamar a atenção a formas de discriminação presentes nos métodos de militância da esquerda e a outros tipos de opressão, além da puramente econômica. Pode-se dizer que as feministas serviram, talvez, para legitimar valores que antes eram desprezados pelos grupos de inspiração marxista-leninista. Como veremos adiante, no movimento homossexual, que deve muito ao feminista, tanto em termos de teoria quanto de prática, essa vertente individualista foi mantida e até acirrada. 


\section{O antropólogo pode dar voz aos oprimidos sem se restringir a categorias nativas?}

Um dos aspectos marcantes da contestação cultural da década de 1970 e da glorificação da marginalidade, como maneira de questionar os valores autoritários que permeavam a cultura brasileira, foi uma aparente explosão da homossexualidade. Esta se manifestava através de fenômenos como: a crescente visibilidade da população adepta a práticas homossexuais, a exploração comercial que se deu em torno desse novo público e o desenvolvimento de uma moderna subcultura gay. Esses desenvolvimentos interagiam e eram interdependentes, com consequências que atingiam um público maior. Não se pode deixar de mencionar a importância que tiveram, para a cultura brasileira, como um todo, as propostas de "androginia”, presentes nos trabalhos de Caetano Veloso, Gilberto Gil, Dzi Croquettes, Secos e Molhados, Ney Matogrosso, além de ídolos internacionais da juventude como: Alice Cooper, David Bowie, Lou Reed, Mick Jagger e outros.

Estava em processo uma sensível mudança na maneira como a homossexualidade se relacionava com os outros valores da sociedade. A 
transformação ocorria não só no comportamento dos adeptos de práticas homossexuais, como também no relacionamento do resto da sociedade para com eles. Surgiam grupos de militância política formados por indivíduos que se identificavam publicamente como homossexuais e que procuravam conduzir conscientemente uma dupla alteração: elaborando novas formas de representação do homossexual na sociedade, através de grupos de reflexão, e procurando, através de grupos de atuação, difundir pelo resto da sociedade os novos valores criados.

Entre 1979 e 1981, houve uma grande proliferação de grupos de militância homossexual pelo Brasil inteiro. Esses, em muitos casos, conseguiram um reconhecimento por parte de outros movimentos políticos, filiados a partidos oposicionistas ou autônomos. Em muitos casos, estabeleceram com eles relações de cooperação, embora tendesse a persistir um receio de que qualquer contato mais próximo com esses outros movimentos colocasse em risco a ênfase que se desejava dar às questões ligadas estritamente à homossexualidade.

Foi dentro dessa atmosfera e dessa problemática que tomou corpo o projeto da pesquisa que fundamenta este livro. Através de um estudo detalhado do Grupo Somos de Afirmação Homossexual de São Paulo, procurou-se identificar os problemas específicos, levantados pelos militantes homossexuais e os mais gerais, relacionados às formas autônomas de organização desenvolvidas por outros movimentos sociais urbanos, como o feminista e o negro.

\section{A realização da pesquisa}

No contexto da época, parecia relevante dedicar um estudo mais atento às modificações que ocorriam e que eram pleiteadas no campo das relações sexuais. O feminismo, suas teorias, reivindicações e as atuações políticas que inspirava já eram objeto de atenção de vários estudiosos; a homossexualidade, porém, continuava quase ignorada pelas ciências sociais no Brasil - com honrosas exceções, como alguns trabalhos de Peter Fry e Carmem Dora Guimarães. Apesar de ter uma formação inicial em Psicologia Social, meus contatos com Fry e seu pensamento levaram-me à ideia de resgatar a discussão sobre a questão da homossexualidade do campo médico psicológico, 
no qual recebia uma conotação de "fenômeno natural" para sujeitá-lo à ótica relativizante e desnaturalizadora da antropologia.

Residir na Praça da República, epicentro de uma espécie de "gueto gay"l paulistano e já frequentar esporadicamente esse meio, foram fatores práticos, que me impulsionavam ainda mais a esse propósito. Reforçando esse interesse acadêmico, havia também a questão existencial vivida naquela época por mim e por meus pares, do confronto com velhos tabus de todos os tipos, que nos pareciam ser resquícios do autoritarismo decadente a ser questionados e combatidos, tanto na teoria quanto na prática. A manifestação dos aspectos políticos da contracultura americana e europeia do final da década de 1960 parecia estar finalmente chegando ao Brasil.

Nesse espírito, a concepção inicial do trabalho, formulada em 1979, se prendia muito às ideias em voga, especialmente entre os membros europeus e americanos da "geração 68", a respeito da natureza e dos objetivos que deveriam ter uma pesquisa científica. Com imensos pruridos e autodesconfianças, pensava-se em dar, através do meu trabalho, possibilidade de expressão a uma categoria social que, até então, fora silenciada. Nesse processo, seria meu dever atentar para que esse estudo não se transformasse em um exercício de "falar por", cassando assim, mais uma vez, a voz dos diretamente envolvidos.

Sentia que, para evitar essa usurpação da fala do oprimido, seria necessário deixar bastante claro que não acreditava na existência de uma realidade objetiva exterior que, munido com as armas da ciência, eu desvendaria e tornaria pública. Acreditava que a realidade social seria criação do observador e que sua transposição para o papel iria requerer toda uma série de operações de seleção do material coletado, o que levaria muitas vezes o resultado final a servir mais como um autorretrato inconsciente do autor do que um espelho da realidade objetiva do objeto de estudo.

1 No decorrer deste livro, utiliza-se o termo "gueto", à maneira dos militantes homossexuais da época, para abranger um circuito frequentado por homossexuais masculinos e femininos, composto principalmente por bares, restaurantes, boates, certos cinemas "de pegação" e saunas. Ver também Macrae (1983), para uma discussão mais detalhada sobre suas características e sua importância na formação de uma identidade homossexual. 
Tradicionalmente, a antropologia se ocupava principalmente do estudo de povos ditos "primitivos", cuja cultura era tão diferente daquela do pesquisador que um grande esforço se tornava necessário para estabelecer um nível mínimo de contato. Nessa situação, um estranhamento ou uma alteridade já era parte constitutiva do processo e, geralmente, era mais fácil ao antropólogo desenvolver sua própria interpretação daquela realidade do que absorver e adotar, como sua, a visão de mundo nativa. Porém, uma vez que se começou a empregar métodos de pesquisa antropológicos para o estudo de sociedades modernas, de cujas culturas o próprio pesquisador geralmente partilhava, tornou-se muito mais difícil manter uma postura de distanciamento científico. Esses problemas se exacerbavam ainda mais quando se adotava a postura que eu havia escolhido, a de "dar voz aos oprimidos". Tornava-se quase impossível escapar das categorias "nativas" ou do senso comum, vigentes no grupo que eu havia escolhido para estudar.

Um dos principais precursores do método antropológico que eu havia escolhido foi Sol Tax; inventor da expressão "antropologia de ação". Ele havia dito:

Para nós, os fins não justificam os meios, e a ciência não justi-
fica nada. Portanto, desde o começo definimos a antropologia
da ação como uma atividade na qual o antropólogo tem duas
metas, nenhuma das quais ele relegará a uma posição infe-
rior. Ele deseja ajudar a um grupo de pessoas e deseja apren-
der alguma coisa no processo. Ele se recusa a pensar ou dizer
que as pessoas envolvidas são para ele um meio de adiantar
o seu conhecimento e se recusa a pensar ou dizer que está
simplesmente aplicando a ciência à solução dos problemas
dessa gente. (TAX, 1975, p. 515)

O antropólogo de ação não pode tratar as pessoas que estuda como simples objeto de pesquisa, pois, para ele sentir que conhece uma comunidade, não basta entender sua cultura, traços de personalidade ou a inter-relação funcional das instituições. É necessário que ele compreenda também a forma como concebem as diferentes alternativas com as quais se defrontam em situações de mudanças. Ao mesmo tempo em que esse antropólogo exerce uma posição ativa, agindo, de certa forma, como professor e procurando neutralizar os 
constrangimentos externos que incidem sobre aquela população, ele deve evitar impor soluções que atentariam contra a liberdade daquela comunidade. Isso levaria a um trabalho incompleto, porque o que é melhor para eles seria relacionado ao que eles desejam ser e isto só pode ser compreendido se observarmos as escolhas feitas por eles na prática. $\mathrm{O}$ antropólogo de ação dá muito valor à liberdade, tanto por razões éticas quanto como uma maneira de apreender a verdade. Portanto, ele deve, acima de tudo, recusar-se a encarar ou tratar essas pessoas como meros objetos de estudo.

Esse tipo de abordagem influenciou fortemente toda uma geração de cientistas sociais, especialmente nas décadas de 1960 e 1970, e, para mim, parecia a extensão lógica da postura ultra libertária que eu adotara como filosofia pessoal. Porém, ao aplicá-la à minha pesquisa, deparei-me com sérias dificuldades para manter a posição de objetividade científica que o próprio Tax (1975) enfatizou como sendo importante. Afinal, ele mesmo disse que desejava continuar sendo um antropólogo e não se tornar um propagandista, preferindo estar correto, de acordo com os cânones da evidência, do que impor um ponto de vista a qualquer custo. Para ele isso era mais simples do que para mim, pois Tax (1975) explicitamente reservava seu método para situações nas quais pessoas de culturas radicalmente diferentes estivessem em contato e na qual uma comunidade relativamente pequena estivesse sendo pressionada por uma sociedade mais poderosa. Eu, por meu lado, pesquisando entre pessoas muito parecidas comigo, que tinham seus pontos de encontro a somente alguns metros do prédio onde moro, vi-me, nos termos usados em um artigo de Eunice Durham, passando da "observação participante" para "participação observante" e até militando ativamente. (DURHAM, 1983)

Dentro da perspectiva de "dar voz aos oprimidos", optei por estudar um grupo como o Somos-SP, no qual já existia uma tentativa de articular um novo discurso homossexual e no qual estavam reunidas pessoas dispostas a entrar em conflito com a estrutura social e política vigente para efetuar mudanças sociais significativas. Nessas condições, eu achava ser mais fácil detectar e acompanhar os vários aspectos da problemática homossexual. 
Nesse ponto tinha bastante razão; meu contato com o grupo foi muito estimulante e elucidativo, mas o problema do estabelecimento de alteridade se agudizou, pois uma parcela significativa dos integrantes do grupo eram quase idêntica a mim, em termos de classe social, nível educacional, ocupações, filosofia de vida e interesses sexuais.

Espero que, apesar de minha participação intensa no grupo que estudava, assim como minha grande identificação com ele e seus objetivos, eu também tenha conseguido atingir uma visão mais globalizante da questão homossexual, obtendo sucesso em relacionar a militância do Somos aos desenvolvimentos ocorridos no conjunto da sociedade. Procurei não esquecer o alerta feito por Eunice Durham a respeito da existência, dentro do próprio método de trabalho de campo, de uma "armadilha positivista", embutida no processo de identificação subjetiva com as populações estudadas. Durham (1983) não duvida que essa identificação seja necessária para que se possa apreender "de dentro" as categorias culturais com as quais a população articula a sua experiência de vida social e ordena sua prática coletiva. Mas, lembra ela, essa identificação traz consigo o risco de se tentar explicar a sociedade através das categorias nativas, em vez de fazer uma análise realmente antropológica. (DURHAM, 1983)

No caso em que o pesquisador trabalha dentro de uma sociedade complexa como a nossa, os problemas são aumentados pela fragmentação que a caracteriza. Torna-se impossível qualquer tentativa de entender o conjunto da sociedade e o movimento que lhe é próprio a partir dos grupos estudados, pois esse entendimento está fora de seu horizonte de informação, assim como de sua experiência direta. A sociedade, obscura para os interlocutores nativos, torna-se obscura para o próprio antropólogo.

Para sair desse impasse, deve-se procurar dissolver essa visão colada à realidade imediata e à experiência vivida das populações com as quais se trabalha, não se contentando com a descrição da forma pela qual os fenômenos se apresentam, mas indagando do modo pelo qual são produzidos. (DURHAM, 1983) Aqui entra em jogo o papel da teoria antropológica e da abordagem comparativa, geralmente privilégios da reflexão do pesquisador e que lhe podem fornecer a alteridade, tão difícil de atingir no campo. Procurei, portanto, demonstrar 
como é necessário romper com a visão do senso comum, segundo a qual a categoria "homossexual" é simplesmente dada pela natureza, prestando mais atenção à maneira como a ciência e a atuação política têm interagido na sua construção social.

Senti de maneira especialmente aguda a importância de manter um certo afastamento dos sujeitos de minha pesquisa quando, no começo de 1980, se instaurou uma série de conflitos no seio do grupo Somos. Nesse momento, vi-me obrigado a tomar uma posição mais definida e tive de escolher entre dois grupos rivais, ambos integrados por vários bons amigos meus. Nessa hora, foi muito útil para mim já dispor de um certo arcabouço teórico para me permitir uma abstração das pressões que sofria.

Esse arcabouço começou a ser construído a partir de algumas indicações iniciais de leitura, recebidas de Peter Fry. A mais importante foi o artigo da cientista social britânica Mary McIntosh sobre o papel do homossexual, no qual, pela primeira vez, me deparava com um tratamento científico da homossexualidade que não partisse do ponto de vista psicológico. Subsequentemente, os trabalhos de Plummer e Weeks apontaram para a riqueza e justeza desse tipo de abordagem. A leitura do Relatório Kinsey e de alguns trabalhos de Peter Fry terminaram por me persuadir que, mais que uma essência natural de certas pessoas, a homossexualidade revela um mecanismo social de rotulação, o qual age de forma desigual, identificando como homossexuais somente algumas das pessoas que manifestam um certo tipo de atração e comportamento sexual para com outras do mesmo sexo fisiológico.

Durante certo tempo, essa minha postura teórica foi de encontro com algumas das ideias mais caras de influentes integrantes do grupo Somos e, se ela serviu para me ajudar a manter uma certa objetividade científica, também me criou problemas, pois eu temia o risco de fomentar um novo discurso competente, negando e contradizendo a "voz do oprimido".

Explicando melhor, na época em que desenvolvi a pesquisa, o grupo Somos, como um todo, partia do princípio de que a humanidade estaria dividida entre heterossexuais e homossexuais - e, talvez, alguns bissexuais. Essas categorias seriam essenciais à personalidade dos indivíduos e 
quase imutáveis. A sociedade seria preponderantemente dominada pelos heterossexuais masculinos, que buscariam impor seus padrões sobre todo o mundo. Esses padrões seriam geralmente aceitos por todos, mesmo pelos homossexuais, que, em muitos casos, nem se reconheceriam como tais. Um dos grandes objetivos a ser alcançado seria, assim, o auto reconhecimento, por parte desses, e a criação de uma nova "consciência homossexual". Fazendo analogia ao "negro de alma branca", diziam existir igualmente "o homossexual de alma heterossexual", que seria preciso contestar. Minha visão, como já disse, é diferente. Acredito que o homossexual representa um papel social que varia bastante ao longo do tempo, em diferentes regiões geográficas e nas diversas classes sociais. Kinsey (1972) demonstrou que são raros os casos de homossexuais "puros", como também são muito numerosos os heterossexuais que já teriam tido alguma experiência homossexual. Portanto, quando se pensa em uma população homossexual, é necessário lembrar que esta população não é homogênea, nem na sua preferência sexual, nem em sua vivência.

Embora esse conceito seja corrente e aceito nas esferas universitárias, quando colocado a integrantes do grupo Somos, ele provocava reações bastante violentas. Isso porque parecia solapar a solidariedade do grupo pela base, uma vez que seus integrantes se sentiam unidos por uma condição igual. Em uma polêmica entre dois grupos homossexuais de São Paulo foi escrito: "Não nos esqueçamos que na hora do "vamos ver", aos olhos do sistema machista e autoritário que está aí, somos todos simples viados e sapatões e quem não se calar apanha". Geralmente, era considerado inútil, dentro do Somos, discutir a etiologia da homossexualidade, pois tudo o que tem sido escrito ou dito, por eminências acadêmicas, sobre o assunto era tratado com desconfiança e, muitas vezes, visto como reelaboração, em "linguagem difícil”, dos preconceitos machistas que permeiam toda a sociedade. Porém, quando um psicólogo renomado deu uma entrevista falando da homossexualidade em termos de opção e não condição também provocou reações exaltadas de integrantes do grupo. Afirmavam que isso era um absurdo, pois ninguém, dada a chance, optaria por uma vida tão sofrida e difícil. Era importante para a solidariedade grupal esse sentimento de que a homossexualidade seria uma marca inescapável e "incurável". Parecia crucial, para qualquer tentativa de melhorar a 
situação social do homossexual, partir do seu reconhecimento como tal, do seu "se assumir".

A concepção do homossexual como papel social parecia, para a maioria dos integrantes do grupo, negar a sua experiência, pois era comum ouvi-los dizer que, já na infância, se sentiam homossexuais. Realmente, essa concepção sociológica não parece dar conta do sentimento de estranheza e diferença que os homossexuais alegam carregar desde seus primeiros anos.

Confesso ter sentido perplexidade e desconforto várias vezes quando colegas do mundo acadêmico me incentivaram a discutir o conceito de papel social, pois sentia estar simplesmente emprestando mais um pouco de prestígio, conseguido por mim através da ajuda e confiança dos integrantes do Somos, para uma ideia que só tendia a enfraquecer a sua solidariedade grupal.

Receios a respeito das consequências do meu trabalho também foram manifestados frequentemente por outros membros do grupo. Eram seus integrantes mais intelectualizados os que mais suspeitavam dos meus propósitos acadêmicos. Portanto, no dia em que anunciei a minha intenção de realizar uma pesquisa sobre o Somos, sofri um rigoroso questionamento e, depois de longa discussão, ficou decidido que:

O grupo se prestaria como objeto de estudos, com a finalidade de realização de uma tese de pós-graduação. O grupo teria participação ativa na elaboração da mesma, na medida em que o estudioso levaria ao grupo as suas conclusões para efeito de discussão e eventual reelaboração das ideias. Isso possibilitaria a inclusão do ponto de vista dos próprios participantes no corpo da tese, a respeito do material tratado, não limitando o trabalho à tradicional visão monolítica daquele que a redige. ${ }^{2}$

2 Resultado da reunião geral do Grupo Somos - 5 maio 1979 - folhas mimeografadas para circulação interna no grupo.

Durante minha pesquisa tentei várias vezes cumprir essa decisão, mas, como nunca surgia um espaço adequado nas reuniões para tais discussões, fiz fotocópias dos meus trabalhos e os submeti às críticas de alguns integrantes do grupo. Como não me era possível fazer muitas cópias do trabalho, por razões de custo, só alguns tiveram acesso a elas, mas eu procurei mostrá-las aos que revelaram maior interesse no assunto durante a discussão, e especialmente aos que expressaram as maiores reservas a seu respeito. O resultado dessas consultas foi sempre proveitoso para mim e meu trabalho, embora as sugestões feitas não tenham sido muito numerosas. 
Apesar da forma bastante agressiva com que fui tratado por alguns membros do grupo, nessa ocasião, a polêmica me parecia apropriada e as exigências feitas estavam de acordo com certos princípios de pesquisa ativa participante. O sociólogo Orlando Fals Borda (apud GAJARDO, 1986, p. 40), por exemplo, pregava a devolução sistemática dos resultados da pesquisa à população estudada e o uso de uma linguagem acessível ao seu entendimento.

A investigação a que me propunha surgia, para mim, como um espaço de reflexão, não só teórico metodológica, mas como método de ação política. Buscava ajudar legitimar, não só certas práticas sexuais desviantes, mas também resgatar o valor do saber marginal elaborado por seus adeptos, introduzindo-o de forma adequada nos grandes debates, que se travam na sociedade, a respeito da sexualidade e dos papéis de gênero. Nesse contexto, adquiria importância a reconsideração das relações entre o pesquisador e seus interlocutores.

Esse aspecto ficou bastante claro quando houve a discussão no grupo sobre a minha pesquisa e os militantes do Somos declararam que não desejavam ser tratados como simples objetos de pesquisa, exigindo uma participação no que se escrevia a seu respeito. Além disso, expressaram também a sua atitude de suspeita a respeito das atividades e pronunciamentos de supostos peritos no assunto, legitimados pela ciência estabelecida, como psiquiatras e psicólogos. Esses eram percebidos como simples perpetuadores dos preconceitos sociais, apenas revestindo-os de uma linguagem mais complicada ou "científica" e, portanto, mais mistificante. O aparecimento do grupo Somos seria uma das marcas do desejo dos homossexuais de deixarem de ser um grupo social invisível e silencioso, tomando a palavra para si próprios.

Quando eu argumentava sobre as razões pelas quais o grupo deveria permitir que realizasse meu estudo, lembrava da importância de

\footnotetext{
Por outro lado, procurei, em frequentes ocasiões, explicar ao grupo as conclusões a que estava chegando, usando uma linguagem de fácil compreensão. Isso suscitou discussões que, em alguns casos, parecem ter ajudado os militantes a elaborar suas reflexões a respeito de suas atividades, tanto políticas quanto sexo afetivas.

Também busquei atuar ao seu lado, não só participando de suas reuniões e atos políticos, mas também de seus esforços de conscientização do grande público, proferindo palestras em escolas, encontros científicos, etc., sempre defendendo a liberdade sexual.
} 
se ter um registro para a posteridade e da necessidade desse registro ser escrito por alguém treinado e capaz de colocar claramente o ponto de vista homossexual. Perante o sentimento, generalizado dentro do grupo, de que suas atividades eram pioneiras e históricas, ${ }^{3}$ esse parece ter sido um dos argumentos mais eficazes.

Havia também outro aspecto da questão a ser encarada sobre o respeito devido aos indivíduos integrantes do Somos. Portanto, ao relatar a dinâmica do grupo, optei por privilegiar certas argumentações explícitas, deixando de lado o emaranhado de relações afetivas subjacentes. Lidar com essas relações, especialmente quando ocorrem dentro de nossa própria cultura, é bastante delicado, por razões éticas e afetivas. Outros cientistas sociais também têm procurado evitá-las. Maria Moraes, por exemplo, ao ter que enfrentar dificuldades desse tipo, em sua tese sobre a imprensa feminista, decidiu permanecer num nível mais generalizante. Mesmo assim, algumas passagens deixam entrever um processo muito complexo envolvendo o impacto das relações amorosas, de amizade ou antipatia, na discussão política. (MORAES, 1981, p. 241) Similarmente, Rosemarie Lobert, ao escrever sua tese sobre os Dzi Croquettes, também evitou se aprofundar em certos aspectos da vivência homossexual dos integrantes daquela trupe teatral, além de manter total silêncio sobre o considerável uso que faziam de diversas drogas ilícitas. (LOBERT, 1979) Neste trabalho também relutei em discutir em maior detalhe as relações afetivas que se desenvolveram entre os militantes do Somos.

Tais dificuldades parecem ser o preço que o antropólogo deve pagar, ao tentar combinar uma análise científica com a documentação fiel da atuação de grupos cuja composição é amplamente conhecida dentro de sua própria sociedade, ao contrário do que ocorre quando o objeto de estudo é uma remota tribo indígena, por exemplo, onde o anonimato dos atores é protegido por distâncias geográficas e culturais. Em casos como o deste relato, contrariamente ao exemplo, é provável que uma parcela do público leitor conheça pessoalmente os indivíduos em questão, tornando, assim, difícil até a adoção do tradicional estratagema de disfarçar identidades.

3 Nesse sentido, os membros veteranos do Somos eram conhecidos como "bichas históricas". 
Minha fé na correção de me ater a um ponto de vista elaborado a partir de reflexões mais científicas e isentas do que aquelas da militância foi validada com o passar do tempo, devido às mudanças que vieram a ocorrer no próprio posicionamento do grupo sobre a natureza da homossexualidade. O Somos revelou-se um importante fórum para discussões sobre questões relacionadas a essa orientação sexual e, em diferentes momentos, diversos pontos de vista foram apresentados aos seus militantes. Isso os ajudou a sofisticar consideravelmente suas concepções e a deixar de lado divisões maniqueístas do mundo, como a distinção feita entre homossexuais e heterossexuais e até entre machistas e libertários.

$\mathrm{O}$ assunto de que trato aqui há muito me interessava. Na época em que a pesquisa de campo foi feita, eu sentia que, mais que os partidos tradicionais, cujas fórmulas pareciam bastante desgastadas, eram os grupos "minoritários", como o das mulheres, dos homossexuais, dos negros, dos índios, etc., que propunham enfoques novos. Achava especialmente atraente a combinação pretendida entre a experiência comunitária e uma política que respeitasse as necessidades individuais. Porém, essa harmonização do socialmente desejável com a autonomia individual é muito difícil de atingir. Este livro procura ser um estudo detalhado da tentativa feita pelo movimento homossexual de pô-la em prática, mas também, de maneira mais geral, buscará relacioná-la a problemas similares, que surgem em outros movimentos sociais urbanos contemporâneos, tais como o negro e a feminista.

Atualmente, ${ }^{4}$ grande parte dessas organizações políticas está em recesso ou então passando por uma crise crônica. Nenhum dos movimentos conseguiu se tornar um grande movimento de massas, mas os efeitos de suas atividades se fazem sentir e, no campo da mudança de atitudes sociais, certamente, foram alcançadas grandes vitórias. Entre os membros do Somos ou aqueles que frequentavam o chamado "gueto gay" de São Paulo, existe hoje, por exemplo, um sentimento de liberdade e destemor bastante grande, assim como um sentimento de autovalorização muito mais positivo do que há alguns poucos anos atrás.

4 Este texto se refere aos períodos de 1979 a 1980, quando a pesquisa de campo foi realizada, e a 1988, quando a primeira edição do livro foi realizada. 


\section{Identidade homossexual e política}

As categorias "homossexual" e "homossexualidade" foram inicialmente desenvolvidas por médicos e sexólogos do século XIX, dentro de um contexto de campanhas políticas contra a penalização de práticas homossexuais no recém-criado Império Alemão. Desde então, a maior parte das discussões científicas sobre o tema tem se dado principalmente nos campos da medicina e da psicologia. Mais recentemente, cientistas sociais têm procurado entender esse fenômeno como uma "construção social". Em tal abordagem, procura-se fazer distinção entre o comportamento, os papéis, categorizações e identidades homossexuais. ${ }^{1}$ Não só as atitudes perante

$1 \bigcirc$ antropólogo anglo-brasileiro Peter Fry ressalta a importância de se diferenciar quatro componentes básicos usados na construção de identidades sexuais afetivas:

a) Sexo Fisiológico - Os atributos físicos através dos quais distinguem-se machos e fêmeas São invariáveis de um sistema cultural para outro;

b) Papel de Gênero - $\bigcirc$ comportamento, os traços de personalidade e as expectativas sociais normalmente associadas ao papel masculino ou feminino. O papel de gênero é definido culturalmente e não é necessariamente determinado pelo sexo fisiológico;

c) Comportamento Sexual - O comportamento relacionado ao ato sexual esperado de qualquer identidade. Salienta-se o ato da penetração ou de ser penetrado, concebidos na cultura brasileira como "atividade" ou "passividade";

d) Orientação Sexual - Basicamente uma referência ao sexo fisiológico do objeto sexual. Nesse sentido, um individuo pode se orientar homo, hetero ou bissexualmente. (FRY, 1982, p. 90) 
a homossexualidade são passíveis de variações, como também os significados sociais e subjetivos com que ela é investida. Torna-se, portanto, impossível pensar em uma história universal da homossexualidade. O significado social desse comportamento, tanto em termos de resposta social quanto em termos de identidade individual, só pode ser apreendido dentro de um contexto histórico específico, como se tenta fazer neste livro.

As abordagens sociológicas e antropológicas da questão partem do princípio de que não faz sentido pensar em uma essência comum a todos os que são rotulados como homossexuais e que possa servir para diferenciá-los daqueles socialmente considerados como heterossexuais. Nessa linha, incluem-se os trabalhos pioneiros de Mary Mcintosh $(1968,1981)$ e de Evelyn Hooker $(1957,1973)$, além das de Bell (1979), Weeks (1977, 1981, 1985, 1986), Fry (1982), Padgug e Plummer (1981), Foucault e outros. Essa posição recebe confirmação nas próprias ciências biológicas, que têm registrado constantes fracassos nas suas tentativas de ancorar tendências homossexuais à constituição física dos indivíduos. Tampouco os psicólogos têm conseguido demonstrar a existência de uma personalidade homossexual e muito menos propor uma etiologia convincente, a ser geralmente aceita, para a homossexualidade. (HART; RICHARDSON, 1983; HOOKER, 1957)

Entre os atuais adeptos dessa abordagem social é comum a concordância com a afirmação foucaultiana de que, embora a ocorrência de práticas homossexuais remonte aos primórdios dos tempos, foi somente a partir do século XVIII, com a implantação daquilo que Foucault chama de "dispositivo da sexualidade" que surge um personagem - o homossexual - concebido como membro de uma espécie e dotado de características pessoais próprias. Até então, a "sodomia" era considerada uma atividade contra a natureza, um "pecado nefando", às tentações do qual, todos seriam suscetíveis.

Embora bastante aceita, tal visão ocasionalmente suscita oposições, tanto por parte de alguns praticantes das ciências médicas e biológicas, quanto da parte de certos importantes psicanalistas como Bieber e Socarides. (MARMOR, 1973) Mesmo no campo das ciências sociais, o respeitadíssimo historiador J. Boswell fez algumas ressalvas à análise de Foucault, dizendo que, antes do advento das 
sociedades capitalistas modernas, já existiam, concomitantemente, várias maneiras de classificar socialmente a sexualidade, incluindo-se aí categorias baseadas na escolha do objeto sexual, similares às nossas categorias "homossexual" e "heterossexual". Porém, segundo o próprio Boswell (1983), o que esse amplo espectro de opiniões a respeito da categorização sexual revelaria sobre a natureza intrínseca da sexualidade humana permaneceria em aberto e suscetível de muitas interpretações divergentes.

Deixando de lado a questão de supostas etiologias ou a noção de que se determinados indivíduos teriam ou não uma propensão inata à homossexualidade, reafirmo aqui a posição clássica na antropologia, segundo a qual dados da natureza não podem ser apreendidos, senão através de categorias culturalmente construídas, extremamente variáveis no tempo e no espaço. Portanto, quando uso neste livro o termo "os homossexuais", quero referir-me aos indivíduos adeptos de práticas sexuais com outros do mesmo sexo fisiológico. Igualmente, o adjetivo "homossexual" será empregado como qualificador referente a essa categoria geral, independente de como determinados indivíduos possam se conceber ou serem percebidos pelas suas sociedades. É importante enfatizar essa variedade, pois, como veremos, eram bastante diversas as ideias, a respeito da homossexualidade e do homossexual, vigentes na época de atuação do grupo Somos.

Conforme já mencionamos, desde o final da década de 1960, a visibilidade da homossexualidade nas cidades brasileiras tem aumentado consideravelmente. Isso se relaciona ao fato de um número crescente de indivíduos assumir uma identidade homossexual; pela qual entendo uma organização da personalidade e uma maneira de se relacionar com o mundo baseado numa certa representação de si, fundamentada em categorizações sexuais geradas pela cultura em que se inserem, dividindo os indivíduos entre homossexuais, heterossexuais e bissexuais.

O aumento dos homossexuais visíveis tem levado a população, como um todo, a dar mais atenção ao fenômeno, e tem promovido a ideia de que, apesar de certos grupos de militantes políticos homossexuais dizerem não desejá-la, parece haver uma tendência à sua integração na sociedade. Afinal, talvez a sociedade não tenha que 
sofrer mudanças muito radicais para permitir alguma acomodação, alguma convivência.

Concomitantemente às mudanças que ocorrem ao nível social mais amplo, está se alterando a forma como homossexuais se veem e se relacionam entre si. Em primeiro lugar, está diminuindo a carga de sentimento de culpa que pesa sobre esses indivíduos. Com o declínio da influência da religião cristã e do seu papel de valor normativo da sociedade de consumo urbana, há uma tendência a deixar de ver o prazer sexual como intrinsecamente pecaminoso. Novos conceitos entram no lugar do antigo pecado: anormalidade, doença, desvio, etc. Embora carregados negativamente, possuem a vantagem de se reportar ao mundo racional, passível, portanto, de questionamento através da razão. É muito mais fácil, por exemplo, argumentar que a "natureza" é um conceito relativo e que, portanto, a "antinaturalidade" do homossexualismo também o é, do que ir contra preceitos bíblicos baseados numa suposta revelação divina.

Embora continuem a vigorar uma série de fatores inconscientes, acessíveis somente através de análises profundas, é inegável que discussões entre amigos e a força do exemplo ajudam intensamente os indivíduos a se sentirem menos culpados em relação à sua conduta sexual. Não é à toa que uma das atividades mais bem-sucedidas dos grupos homossexuais militantes seja a formação de grupos de reflexão e troca de experiências. De maneira mais informal, o mesmo processo se repete nos bares, discotecas e outros estabelecimentos que compõem o chamado "gueto gay".

O desenvolvimento do gueto homossexual em São Paulo já foi bastante discutido pelo antropólogo Perlongher (1987, p. 68) e, portanto, basta recapitular que se trata de uma região central, onde se situam certos bares, saunas, boates, banheiros públicos e parques que servem como pontos de encontro de homossexuais. Além dessa área central, existem outras regiões menores de aglomeração ou de perambulação homossexual espalhadas tanto em regiões nobres quanto em bairros populares.

Mesmo depois de se conseguir uma certa libertação dos antigos preceitos religiosos que condenavam a homossexualidade e torturavam seus praticantes com angustiantes sentimentos de culpa, estes 
indivíduos continuam a ser constantemente ameaçados por sanções sociais como: a ridicularização, o desemprego, o ostracismo, a perseguição policial e até a prisão. Apesar das manifestações de protesto, vindas da comunidade homossexual, e das declarações dos últimos secretários de segurança do Estado de São Paulo, condenando as arbitrariedades perpetradas por seus agentes contra homossexuais, continua a prática policial de efetuar periódicas "limpezas" nos bares e em alguns pontos do gueto paulista, prendendo seus frequentadores para averiguação.

Esses ataques periódicos ao gueto são especialmente nocivos ao bem estar psíquico e social dos seus frequentadores, porque é lá que normalmente as pressões sofridas no cotidiano são amainadas, novos valores são desenvolvidos, dotando o homossexual de mais condições para "se assumir" e testar uma nova identidade social. Uma vez construída a nova identidade, ele adquire coragem para assumi-la em âmbitos menos restritos e, em muitos casos, pode vir a ser conhecido como homossexual em todos os meios que frequenta. Por isso, é da maior importância a existência do chamado gueto gay, que mais cedo ou mais tarde também acaba afetando outras áreas da sociedade, criando novos espaços de democracia sexual.

Além de demonstrarem um maior grau de autoconfiança em suas relações com a sociedade envolvente, os homossexuais também estão mudando a forma como se relacionam entre si. Tradicionalmente, em se tratando de papéis sexuais, a sociedade tem dividido os indivíduos em dois tipos: o ativo (homem), e o passivo (mulher). Essa categorização está extremamente arraigada na nossa cultura e não surpreende que se encontre reproduzida nas relações homossexuais, com os homens classificando-se como "bofe" e "bicha", e as mulheres como "fanchona" e "lady", por exemplo.

Em ambos os casos, os primeiros seriam "ativos" e os segundos "passivos", reproduzindo as relações de dominação vigente entre homens e mulheres. Mas, assim como entre homens e mulheres estão ocorrendo mudanças notáveis, também entre casais homossexuais está se dando uma diluição da dicotomia ativo/passivo a partir da maior democratização do relacionamento. Isso parece ocorrer, principalmente, entre os moradores das cidades grandes, de níveis socioeconômico e educacional mais elevados. 
Esse novo modelo de relacionamento homossexual parece ter se desenvolvido em São Paulo - assim como em outros grandes centros urbanos -, por volta do final da década de 1960, quando certas áreas do centro da cidade, como a Galeria Metrópole, na Av. São Luís, tornaram-se pontos frequentados, não só pelos homossexuais, mas também por grupos de boêmios politizados. Esses boêmios, artistas, intelectuais e estudantes, inconformados com a ditadura militar e frequentemente engajados em diversas modalidades de contestação cultural, procuravam resistir e subverter o regime através do questionamento dos valores conservadores e autoritários que regiam a sociedade. Do encontro dessas duas populações marginalizadas resultou um processo de influência mútua. Os contestadores culturais encontraram um novo campo onde atuar, percebendo a importância de se dissolver a rigidez das normas que governavam o desempenho dos papéis de homem ou de mulher na sua sociedade. Entre os homossexuais, exerceu-se uma influência mais democratizante nos relacionamentos sexuais e afetivos. Dois importantes resultados desse encontro foram: a consolidação da figura do "entendido", o homossexual que buscava relações sexuais igualitárias; e a valorização da androginia, enquanto postura política.

Essa última vertente devia muito de sua força aos rigores da censura então operante que predispusera o público a procurar mensagens cifradas nas ambiguidades dos textos e espetáculos. Por volta de 1973, surgia, inicialmente no Rio de Janeiro e depois em São Paulo, um espetáculo teatral inteiramente calcado na ambiguidade, tomada como valor em si. Apresentado por uma trupe/comunidade que se intitulava Dzi Croquettes ou Familia Dzi, o show era totalmente composto por homens, que dançavam, cantavam, representavam e improvisavam, apresentando um espetáculo que não se enquadrava muito facilmente em nenhum dos gêneros teatrais mais convencionais. A liberação sexual atingia, assim, a dissolução dos tradicionais papéis de gênero, tão fortes na cultura brasileira. O insólito do seu trabalho era realçado pelas roupas e maquilagens usadas em cena, pois apresentavam homens barbudos com o rosto e o corpo pintados de purpurina, usando os mais desencontrados acessórios do guarda-roupa feminino, por cima dos seus corpos másculos e peludos. Aparecia uma nova figura que desrespeitava todas as classificações de gênero, inclusive a do 
travesti tradicional e que dizia pretender aliar "a força do homem à graça da mulher”. Por falta de termo melhor, a imprensa batizou esta figura de "andrógino". (LOBERT, 1979, p. 11)

Encontrando um público já sensibilizado aos valores postulados pelos "marginais" do underground americano ou europeu e oferecendo um produto cuja ambiguidade essencial permitia uma ampla liberdade para ler o que se quisesse nas entrelinhas, o sucesso inicial do grupo foi estrondoso e de grande repercussão cultural. Embora já não cause mais o escândalo original, até hoje ainda presenciamos os remanescentes de seu estilo, encontrados, por exemplo, em muitos aspectos da performance do cantor Ney Matogrosso, para citar somente um trabalho de maior sucesso. Mais ou menos nessa mesma época, Caetano Veloso aparecia em seus shows com a boca pintada de batom vermelho e usando uma fantasia de baiana. Embora não se tratasse de uma atitude totalmente nova, esses eventos foram importantes ao caracterizar como contestação política o questionamento da rigidez dos papéis de gênero.

Quanto ao "entendido" - ou gay como hoje é frequentemente conhecido -, ocorria, nos seus relacionamentos sexuais e nas suas formas de categorizar os homossexuais, um deslocamento na ênfase, anteriormente colocada nos papéis determinados por comportamento sexual - quem penetra quem -, para o relacionamento visto de maneira mais abrangente. Importava muito mais, a partir de então, com quem o indivíduo se relaciona: se com pessoas do seu próprio sexo fisiológico ou não. Essas pessoas se definem não mais como ativas ou passivas, mas sim como heterossexuais ou homossexuais, questionando, assim, a validade dos papéis preestabelecidos, sendo que, muitas vezes, até se sentem constrangidas ao serem forçadas a exercê-los. Em comparação à antiga hierarquia, traduzida pelas expressões "bofe/bicha", onde só o último era estigmatizado e concebido como devendo servir a seu "macho", a nova categorização sexual era essencialmente igualitária. (FRY, 1982, p. 87) Ambos os parceiros se consideravam igualmente "homens" e merecedores de todo o respeito aos seus direitos de cidadania.

Apesar da popularização e alastramento desse modelo gay, ainda hoje, em muitas áreas, a dicotomia bofe/bicha, ativo/passivo, continua 
a ser importante. Nos meios de comunicação de massa, continua a se propagar a visão que associa o homossexual ao passivo; com raras exceções, o "desmunhecar" é essencial para qualquer representação desse tipo de personalidade. Por outro lado, mesmo entre os homossexuais, as chamadas "bichas pintosas" - os homens muito afeminados - sofrem uma discriminação, por parte daqueles que internalizaram os preconceitos da sociedade, passando, então a extravasá-los às custas dos que consideram escandalosos e cuja companhia seria comprometedora.

Atualmente, a aparência viril é cada vez mais prezada e começa a surgir um novo homossexual estereotipado, que frequentemente ressalta sua aparência máscula, exibindo bigode, barba, músculos de halterofilista, etc., sem, porém reivindicar uma identidade heterossexual. No Brasil, esse fenômeno é mais comum na classe média e ainda não se chegou à situação americana, na qual se alastra a moda macho man, com o farto uso do couro, insígnias nazistas e até um certo culto ao sadomasoquismo.

Intrinsecamente relacionada à questão da reprodução dos papéis sexuais tradicionais, está a da travesti e do transexual, indivíduos que, em alguns casos, chegam a se submeter a dolorosas e caras cirurgias, para adquirirem características externas do sexo oposto. As feministas e muitos integrantes do movimento homossexual frequentemente os consideram como meros reprodutores da vigente organização dos papéis sexuais. Alguns, contudo, veem, no fato de um homem conseguir passar por mulher, uma subversão da ideologia que defende a "naturalidade" da diferença entre os sexos.

A maioria dos homossexuais parece nutrir profundo desprezo e antipatia pelas travestis, alegando que estes simplesmente alimentam os preconceitos dos heterossexuais, segundo os quais todo homem homossexual desejaria, na verdade, virar mulher. Mesmo a chamada "bicha pintosa" já sofre essa discriminação. As travestis respondem às críticas alegando que são elas os verdadeiros homossexuais assumidos; e que sempre formaram a vanguarda, abrindo novos espaços, sem medo de enfrentar as repressões mais violentas. Como dizem: "para ser travesti é preciso ser muito macho".

Além dos homossexuais frequentadores do gueto, existem muitos indivíduos dados a práticas sexuais com parceiros do mesmo sexo, 
mas que o fazem de forma mais discreta e muitas vezes até furtiva. Muitos desses aderem à categorização tradicional e hierárquica da homossexualidade e até se consideram heterossexuais. Isso ocorre constantemente, por exemplo, entre os "michês", praticantes da "prostituição viril” no dizer de Perlongher $(1984,1987)$. .Estes repudiam uma identidade homossexual, em parte, por exigência de sua clientela, que deseja ver neles a encarnação do tradicional ideal de "macheza". Assim como as travestis, esses expoentes do modelo hierárquico de categorização sexual também sofrem o desprezo de outros homossexuais, inclusive de seus clientes. Isso é devido tanto a eles "se assumirem", quanto à sua condição marginal, sendo comum praticarem atos de banditismo contra seus fregueses. Perlongher (1987) mostra como, em muitos casos, o risco que representam é a própria fonte de atração que exercem.

Atualmente, em virtude da grande divulgação de informações a respeito do mundo homossexual, os "clandestinos" podem manter um contato a distância com os novos desenvolvimentos e os novos valores do gueto. Mas esse continua a ser um importantíssimo centro de questionamento e inovação das práticas sexuais e das diversas maneiras de pensar sobre elas.

Em geral, a discussão da homossexualidade tem sido liderada por pessoas que aceitam para si a classificação de homossexual ou bicha. Foi a partir de uma campanha iniciada pelo Grupo Gay da Bahia e finalmente encampada por numerosos setores progressistas da sociedade, que se conseguiu abolir o código 302-0 do INAMPS, no qual o homossexualismo era rotulado de "desvio e transtorno sexual". No começo de 1985, o Conselho Federal de Medicina resolveu que passaria a orientar os médicos brasileiros a codificar a homossexualidade na categoria V-62: “Outras circunstâncias psicossociais”, ao lado de certas condições não patológicas como desemprego, efeitos adversos do ambiente de trabalho, circunstâncias legais, recusa de tratamento por razões religiosas ou de consciência, etc.

Mas essas aparentes vitórias, em termos de integração social e de aquisição de direitos de cidadania dos homossexuais são às vezes vistas com reservas. Há os que se dizem preocupados com a possível cooptação da homossexualidade por parte da moderna sociedade 
capitalista, através de uma normatização que neutralizaria seu potencial subversor da ordem instituída. Nesse sentido, o movimento homossexual é ocasionalmente acusado de contribuir para um rígido reforço das categorias sexuais. No grupo Somos, assim como em todos os outros grupos homossexuais brasileiros, não se permitia a participação de indivíduos que se identificassem como heterossexuais e até os bissexuais eram encarados com certa reserva. O GALF ia mais além e só admitia homossexuais femininos como integrantes e o Adé-Dudu, de Salvador, somente homossexuais negros.

Alega-se que essas posturas acabavam por revalidar o uso do rótulo "homossexual", concebido por alguns como sendo uma forma de controle social imposto a um indivíduo por forças sociais externas ou voluntariamente adotado por ele. A prática de "se assumir", encorajada pelos grupos, correria o risco de não ser nada revolucionária. Significaria pouco mais do que uma mera acomodação de comportamentos e sentimentos, até então em desarmonia com as normas gerais, permitindo aos homossexuais se integrarem mais funcionalmente à estrutura vigente. Representaria somente o estabelecimento de novos padrões que simplesmente mudavam o lugar da linha de demarcação entre o permitido e o proibido. O "homossexual comportado", cujos valores e forma de vida se aproximam bastante daquela dos heterossexuais, seria aceito, mas os personagens incômodos, como as travestis, os pedófilos, etc., continuariam rejeitados. Nessa vertente, Hocquenghem (1980, p. 9), um desiludido militante do grupo francês FHAR, antevê um momento em que os movimentos feministas e homossexual se imobilizarão em um novo estatuto, que os meios de comunicação do Ocidente tratariam de massificar. No Brasil, também se levantam dúvidas semelhantes. Em artigo publicado pela Folha de São Paulo, por exemplo, Peter Fry distingue duas formas de abordar a homossexualidade. Segundo ele, pode-se fazer duas perguntas: "Fulano é ou não é homossexual?", ou então, "Sicrana transa mulher?". Dessas duas perguntas, ele prefere a segunda, pois, como diz:

A pergunta supõe que o desejo sexual para um parceiro do mesmo sexo é apenas um aspecto das atividades da pessoa, e que qualquer um tem esse aspecto em potencial. Em suma, a primeira pergunta supõe que as pessoas são homossexuais, 
heterossexuais ou bissexuais, enquanto a segunda tem como pressuposto que as pessoas estão circunstancialmente qualquer uma dessas coisas.

A movimentação em torno da defesa dos "homossexuais" tem por objetivo a libertação sexual, mas contribui noutro sentido, para um novo controle da sexualidade [...]. Ao pressionar pessoas a seguirem determinadas carreiras sexuais, corre-se o risco de desempenhar o papel de eliminar a anomalia e a ambiguidade da vida da sociedade e do indivíduo. São apresentadas duas opções excludentes que deixam de lado muitas outras. (FRY, 1982b)

Embora reconhecendo a importância da consolidação da categoria "homossexual", para combater o estigma social, ele pergunta se o conforto de um gueto bem arrumado é tudo o que se pode desejar, e termina:

Fourier sonhou com uma sociedade assim, toda divididinha em compartimentos especializados. Mas não seria também possível sonhar com um outro tipo de sociedade menos categórica? Talvez não, mas a supressão da pergunta "afinal de contas é ou não é?", e a sua definitiva substituição pela segunda, "sicrana (fulano) transa mulher (homem)?", poderia ser um passo, ao menos, interessante. (FRY, 1982b)

Jean-Claude Bernardet, discutindo a questão de alguém se definir como homossexual ou não, diz que entrar numa categoria pode ser tranquilizador, mas também é castrador.

Homossexualidade não é privativo dos homossexuais, nem heterossexualidade de heterossexuais, nem masculinidade de homens, nem feminilidade de mulheres. Homo e heterossexualidade não designam estados, mas formas ou possibilidades de comportamentos extensivos ao conjunto do corpo social, envolvendo todas as pessoas, independente da forma específica de sua genitalidade e da prática sexual a que se entregam, exclusiva ou predominantemente [...]. A definição como homo ou heterossexual remete ao ser, à essência de um ser, idêntico a si próprio, pedra de toque, princípio central organizador e aferidor de tudo mais. Fissuras profundas desestabilizaram esse ser e as colmatagens aqui e lá não convencem muito. Esse ser (aos pedaços) não seduz mais, não é mais o rei de nosso imaginário, não é mais um princípio produtor de poesia. O que nos atrai, nos seduz, o que vivemos 
hoje como princípio produtor é o movimento, fluir ambíguo. Antes as funções que o ser. (BERNARDET, 1982)

Tanto Fry (1982) quanto Bernardet (1982), ao negarem o "ser", favorecendo um "estar" ou um "fluir", parecem rejeitar qualquer noção mais rígida de essência e até de identidade homossexual. Assim como Hocquenghem (1980), apontam para o perigo da simples normatização e recuperação do antigo "desvio" homossexual. Perlongher (1987), ao descrever o mundo dos michês em São Paulo, adaptando para seus fins as teorias de Deleuze e Guattari, caminha na mesma direção, ao evitar falar em identidade homossexual, para se concentrar em "devires”, que deem conta melhor dos sujeitos de seu estudo. É talvez a indefinição, característica por excelência desse grupo social, que leva Perlongher (1987) a criticar tão enfaticamente o conceito de identidade, mesmo no seu sentido psicológico de "imagem coerente do self", afirmando ser ele, antes ao resultado de um pressuposto a priori do observador, que um fenômeno empiricamente registrável.

Não há como questionar a relevância e a importância dessas investidas contra novas formas rígidas e limitadoras na categorização de indivíduos ou grupos. Porém, é oportuno se prevenir contra uma apressada atribuição aos militantes homossexuais de uma defesa intransigente da identidade homossexual, como único ou principal elemento definidor do indivíduo. Afinal, cabe lembrar que o próprio debate em tomo dessa questão se deu, se não especificamente em reuniões organizadas por militantes, pelo menos em decorrência de um contato mais estreito com suas atuações. Assim, é curioso notar como João Silvério Trevisan, por outro lado, atribui justamente a setores do movimento homossexual o questionamento do "assumir-se" uma identidade homossexual. (TREVISAN, 1986, p. 19) Ao contrário de Perlongher (1987, p. 85), que atribui a adoção de um modelo masculinizante aos adeptos da identidade homossexual, Trevisan (1986, p. 20) considera que foram os defensores do "estar" homossexual que acabaram, indiretamente, compactuando com a moda "gay-macho", através da qual os homossexuais, basicamente masculinos, passaram a procurar viver dentro dos padrões sociais de normalidade, evitando, às vezes até agressivamente, a proximidade de estereótipos efeminados. 
Talvez uma explicação para essas avaliações discrepantes seja a de que os militantes homossexuais, apesar de buscarem um consenso entre si, sempre formaram um grupo heterogêneo, no qual ocorriam conflitos, tanto em nível prático quanto teórico, tornando impossível atribuir a eles uma posição hegemônica e estável a respeito de assunto tão complexo quanto este.

Ocorreram muitas mudanças nas ideias dos militantes do Somos durante os vários anos de existência do grupo, que era, afinal, um inusitado e dinâmico espaço para discussões sobre a sexualidade. Este trabalho aborda suas fases iniciais, quando ainda predominava a adoção de uma identidade homossexual ou heterossexual, como fundamental e definidora do indivíduo. Porém, essa posição sofreu, desde o início, questionamentos por parte dos que advogavam uma maior abertura para a bissexualidade ou para considerações de classe social. Tais discordâncias, como veremos em outro capítulo, acabaram contribuindo para a eventual fragmentação do grupo em 1980, momento em que a polêmica teórica tomou-se ainda mais acirrada.

Apesar disso, é necessário reconhecer que dentro do Somos, a despeito das várias mudanças no plano teórico, em termos práticos e efetivos, predominava uma atitude de afirmação homossexual. Essa se manifestava na constante reiteração pública ou privada dessa orientação sexual e na tentativa de mobilização social em defesa daqueles identificados como homossexuais, e na exigência de respeito aos seus direitos de cidadania. A importância dessa posição, num processo de mobilização política, é clara e os receios de que isso se redundasse inevitavelmente na calcificação de novos padrões sexuais pode ser exagerado. Sobre isso parece bastante esclarecedora a observação de Michel Foucault a respeito do surgimento do discurso da homossexualidade:

Deve-se conceber o discurso como uma série de segmentos descontínuos, cuja função tática não é uniforme nem estável. Mais precisamente, não se deve imaginar um mundo do discurso, dividido entre o discurso admitido e o discurso excluído, ou entre o discurso dominante e o dominado; mas, ao contrário, como uma multiplicidade de elementos discursivos que podem entrar em estratégias diferentes... É preciso admitir um jogo complexo e instável, em que o discurso 
pode ser, ao mesmo tempo, instrumento e efeito do poder, e também obstáculo, escora, ponto de resistência e ponto de partida de uma estratégia oposta [...].FOUCAULT, 1979, p. 35)

Ora o aparecimento no século XIX, na psiquiatria, na jurisprudência e na própria literatura, de toda uma série de discursos sobre as espécies e subespécies de homossexualidade, inversão, pederastia e "hermafroditismo psíquico" permitiu, certamente, um avanço bem marcado dos controles sociais nessa região de "perversidade"; mas também possibilitou a continuação de um discurso de "reação": a homossexualidade pôs-se a falar por si mesma e reivindicar sua legitimidade ou sua "naturalidade"; muitas vezes dentro do vocábulo e com as categorias pelas quais era desqualificada do ponto de vista médico. Não existe um discurso do poder de um lado e, em face dele, um outro contraposto[...]. (FOUCAULT, 1979, p. 96)

De acordo com Foucault (1979), estamos inevitavelmente emaranhados em uma malha de micro poderes, posicionados em relações estratégicas entre si. Embora não se possa pular para fora dessa malha, pode-se procurar efetuar mudanças no posicionamento estratégico dos poderes, de acordo com nossos objetivos do momento. O próprio Foucault, em entrevista concedida pouco antes de sua morte, reconhece a importância da postura tradicional dos grupos homossexuais que, baseando-se no conceito de uma identidade de natureza "essencial" para si, têm concentrado nos aspectos de direitos civis, entendendo a liberação sexual em termos de simples tolerância sexual. Ele afirma ser importante termos a possibilidade e o direito de escolher a nossa sexualidade, lembrando que os direitos humanos relacionados à sexualidade continuam a ser importantes e que nem sempre são respeitados. Porém, seria necessário ir um passo além. Para consolidar os ganhos recentes da militância homossexual, naquele momento também se fazia necessário criar novas formas de vida, de relacionamento, de amizade, de arte, cultura, etc., através das opções sexuais éticas e políticas dos homossexuais. Estes teriam, então, não só que se defenderem mas também se afirmarem, tanto como identidade quanto como força criativa.

Não se trata aqui da simples criação de uma cultura homossexual e, sim, de uma cultura da qual o prazer faça parte. Ele nota que, durante séculos, as pessoas em geral, além dos médicos, psiquiatras e 
movimentos de liberação, sempre têm falado a respeito do desejo e não do prazer. Eles têm procurado liberar os seus desejos, enquanto Foucault acha que deveriam criar novos prazeres e esperar que o desejo viesse em seguida.

Continuando sua discussão a respeito de identidades que se formam em volta de novas práticas sexuais, ele afirma:

A identidade é útil enquanto for somente um jogo, um procedimento para manter relações sociais e de sexo/ prazer que criam novas amizades. Mas se a identidade se torna o problema da nossa existência sexual e se as pessoas acham que elas devem "descobrir" a sua "identidade própria" e que esta deve se transformar na lei, no princípio e código de suas existências; se a sua questão perene for: "Será que isto está de acordo com minha identidade?", nesse caso eu acho que eles voltarão a um tipo de ética muito próxima da antiga virilidade heterossexual. Se nós tivermos que nos reportarmos à questão de identidade, terá que ser uma identidade da nossa pessoa única. Mas, as relações que devemos manter com nós mesmos não são de identidade, mas, sim. de diferenciação, criação, inovação. É muito tedioso ser o mesmo. Não devemos excluir a identidade, se ela dá prazer às pessoas, mas não devemos concebê-la como uma regra universal. (GALLAGHER; WILSON, 1984, p. 26)

Entre os estudiosos da obra foucaultiana, a máxima: "onde há poder há resistência” já se tornou lugar comum. Nessa entrevista, ele concorda com a ideia de que a resistência não é só uma negação e sim um processo criativo. Embora dizer "não" às vezes seja da maior importância, resistir seria também um processo de recriar e de mudar. Mas, como a resistência nunca se encontra em posição de exterioridade em relação ao poder, ela sempre está dependente da situação contra a qual ela luta. Desse modo, a definição médica da homossexualidade foi um instrumento muito importante na luta contra a intolerância no século passado e no início do atual. Durante o auge do movimento homossexual no Brasil (1979 e 1980), talvez se pudesse dizer que a ideia de uma "essência homossexual" também foi muito importante para a aglutinação de pessoas dispostas a levantar a questão. Posições que poderíamos chamar de "resistência criativa", como as propostas por 
Fry (1982) e Bernadet (1982), seriam apropriadas a uma segunda fase que se seguiria à consolidação de conquistas no terreno dos direitos civis. Sintomaticamente, seus artigos foram publicados em 1982, já aproveitando um espaço que talvez não estivesse tão aberto a esse tipo de discussão, se não fosse por toda a militância desenvolvida pelos grupos homossexuais nos anos anteriores, nos quais eles mesmos tiveram um importante papel de pioneirismo ao participarem do conselho editorial do jornal Lampião da Esquina, por exemplo.

O sociólogo Michael Pollak, escrevendo sobre a França, também enfatiza a importância do desenvolvimento de um gueto e de uma identidade homossexual, para a sua integração na sociedade se realizar com respeito às suas peculiaridades. Sobre a constituição do gueto, ele comenta: "Esse mundo homossexual, procurado e recusado, símbolo da afirmação de si e da marginalização em um gueto, é um laboratório onde se experimentam novas formas de vida sexual e afetiva". (POLLAK, 1987, p. 85)

Pollak (1987) continua comparando as maneiras como os homossexuais lidam com sua identidade com as vicissitudes dos estrangeiros ou migrantes recém-chegados à metrópole, descritos por Simmel e pela Escola de Chicago. Os migrantes são descritos como desenraizados e marcados por uma lucidez social, fruto de seus deslocamentos sucessivos. Esses "tipos" são descritos como abertos aos contatos múltiplos, mas superficiais. Desenvolvendo uma atitude distanciada e capaz de passar facilmente de um meio a outro, vivem simultaneamente em vários mundos diferentes e dão grande importância à singularização e, portanto, à individualidade. Tratando- se de construções de si em torno da liberdade sexual, esses traços característicos, diz Pollak (1987), deveriam ser baseados, entre os homossexuais, tanto na expressão da sexualidade quanto no estilo de apresentação de si, variável de acordo com o seu desejo de marcar a diferença.

Uma geração, criada em um clima mais tolerante com relação à homossexualidade e capaz, portanto, de viver sua diferença sem sentir a necessidade de enfatizá-la, talvez venha a recusar as manifestações mais provocativas do gueto. Mesmo assim, certos tipos estereotipados e o termo "gay", intimamente ligados ao mito do gueto, representam uma etapa necessária num processo mais geral, contraditório e 
multiforme, através do qual os grupos marginalizados tendem a se dotar de uma identidade coletiva. Realizam isso através de uma estilização de sua diferença, indispensável à constituição da força necessária para a promoção de uma integração social em que se respeite a diversidade. Processo semelhante se daria entre a comunidade negra americana. (POLLAK, 1987, p. 85)

Juntamente com o movimento feminista cujas militantes também recorriam a uma problemática "identidade de mulher", as organizações políticas homossexuais conseguiram introduzir importantes alterações nas conceituações mais sofisticadas da ética sexual no Brasil. Levaram ao questionamento dos tradicionais julgamentos a respeito da natureza das práticas sexuais, enfatizando o seu contexto e seu significado para os que dela participam. Apontaram para a emergência de novos valores baseados naquilo que Weeks chama de "pluralismo radical". (WEEKS, 1986, p. 115) Isso implica em considerar como positivo o fato de serem diversos os gostos, prazeres e relações. Deixa-se de ver o sexo como algo pecaminoso ou perigoso, para concebê-lo como moralmente neutro em si. $\mathrm{O}$ seu aspecto mais interessante passa então a ser o campo das possibilidades que apresentam e que devem ser julgados no contexto onde ocorrem. Abre-se, assim, o caminho para uma aceitação da diversidade, como a norma de nossa cultura e como maneira apropriada de se pensar a respeito da sexualidade.

Talvez, essa maior tolerância ainda esteja restrita a certos setores mais "progressistas", mas, a dinâmica do processo cultural tende a difundi-la para parcelas mais amplas da população. Exemplo disso é o enorme espaço que os meios de comunicação de massa vêm dedicando nos últimos anos a discussões menos preconceituosas sobre questões relacionadas à sexualidade. 


\section{O jornal Lampião da Esquina}

Embora o Lampião seja o jornal homossexual que tenha ficado mais conhecido e que tenha atingido um público maior, graças ao profissionalismo de sua equipe de jornalismo e à sua ampla distribuição, ele não foi único. Outras publicações, dedicadas a um público homossexual, já haviam surgido anteriormente e continuaram a ser editadas depois do desaparecimento daquele jornal, mesmo que, em sua maioria, não conseguissem manter uma periodicidade regular.

Diz-se que chegaram a circular 27 publicações gays no Brasil, na década de 1960 e no começo de 1970. Na sua maioria, eram mimeografados e, ocasionalmente, xerocados. Agildo Guimarães e Anuar Farah, dois dos principais responsáveis por essas publicações no Rio de Janeiro, admitem, em entrevista concedida a Leila Mícolis, que eram trabalhos ingênuos, embora não se pudesse deixar de reconhecer o seu valor criativo, inclusive quanto aos seus recursos de impressão. (MÍCOLIS, 1980) Alguns eram verdadeiras obras de arte artesanais, como os jornaizinhos baianos de um único exemplar, feitos à mão por Waldeiton Di Paula, o Gente gay de 1976, que trazia reduções e reproduções de fatos por processo de xerox e uma diagramação moderna.

A maioria dos textos desses jornais falava de amenidades e acontecimentos mundanos, embora também houvesse indicações culturais, reportagens, classificados, concursos de contos, poemas, roteiros 
gays, textos transcritos de jornais ou revistas de grande imprensa, assinados por nomes como Darcy Penteado, Antonio Bivar e outros.

A distribuição era geralmente feita de mão em mão, nos lugares de encontro dos homossexuais: boates, bares e restaurantes, por exemplo. Embora sua circulação fosse geralmente minúscula, esses zamiztats da homossexualidade ocasionalmente atraíam as atenções da repressão policial. Anuar Farah, por exemplo, uma vez foi chamado para comparecer ao Departamento de Ordem Política e Social (DOPS) do Rio de Janeiro para prestar declarações sobre o seu Le Femme, mas a polícia não achou necessário levar o assunto adiante.

Além da qualidade de produção, esses jornais também diferiam do Lampião pelo fato dos seus autores geralmente esconderem suas identidades atrás de pseudônimos femininos. Isso, provavelmente, por duas razões: para evitar prejuízos às suas vidas profissionais ou familiares, e também porque, naquele tempo, a maioria dos homens que se consideravam como homossexuais ainda aderiam ao sistema tradicional de ordenação de identidades sexuais no qual "as bichas" eram geralmente associadas ao papel de gênero feminino. (FRY, 1982, p. 87)

Publicações nesse estilo continuam a ser produzidas até hoje. No Rio, por exemplo, circula, com periodicidade irregular, o Okzinho, órgão da Turma OK. Esta é uma associação de homens que têm como divertimento o transformismo ${ }^{1}$ praticado durante suas reuniões. Significativamente, a média de idade de seus associados é mais alta do que a dos grupos de militância homossexual, de quem fazem questão de se diferenciar, como diz Anuar Farah (apud MíCOLIS, 1980, p. 6-7):

O que é movimento homossexual? Meia dúzia de viados escandalosos, no meio da rua, com tabuletas "queremos igualdade, queremos aquilo, eleger fulano, abaixo isso? [...] Acho uma anarquia. Agora: se o movimento homossexual é esta liberdade que nós temos hoje, essa motivação, esse trabalho honesto que fazemos, você vai ao teatro e assiste atuações como o da Camille, da Rogéria, você liga televisão, vê tex-

1 Transformismo: prática de adotar temporariamente o aspecto do sexo oposto, sem alterar permanentemente o corpo. Transformistas geralmente são homens que se vestem de mulher durante algumas horas, para depois voltarem a assumir plenamente o papel de gênero masculino. 
tos maravilhosos como o Crime do castiçal, pega o jornal de vocês (Lampião) e encontra coisas sensacionais, realmente honestas, então isso é o movimento. Mas tem gente que diz que estamos trancados dentro de uma garrafa. Isso é ridículo. Acho que nós estamos atuantes, estamos aí, todo mundo pela rua, um movimento incrível, tudo o que se faz é honesto, aí eu acredito: agora essa questão de política não, não aceito, não existe mesmo.

Ressaltando as diferenças no estilo da atuação homossexual, convém lembrar que as dissidências entre grupos desse tipo parecem ter uma origem estrutural, sendo quase inevitáveis, como será discutido mais detalhadamente em outra parte deste livro. Os próprios Agildo Guimarães e Anuar Farah, por exemplo, reconhecem que muitas vezes a criação de um jornalzinho novo se dava em função de uma dissidência ocorrida no grupo. Anuar Farah teria deixado o Snob, fundado por Agildo Guimarães, para editar o seu Le Femme. Esses grupos também tiveram uma atuação política embrionária, como a criação de uma Associação Brasileira de Imprensa Gay, que existiu entre 62 e 64, e que, como diz Farah (apud MÍCOLIS, 1980, p. 6-7), tinha o ideal de lutar para mostrar:

que éramos pessoas normais, que fazíamos o que as outras faziam. Normais sempre fomos, sem diferenças[...] Atualmente, eu passo no teatro e olho Camille, Marlene Casanova, e penso que há dez anos atrás elas nunca poderiam fazer isso. Daí, eu acho que, dentro de nossa batalha, nós ganhamos a luta em parte, porque, hoje, quando eu vejo o jornal de vocês (Lampião), vendido numa banca de revista, aberto, sinto que isto é uma vitória também nossa, também nós lutamos muito por tudo isso[...]. Uma das maiores contribuições nossas, na minha opinião, foi, sem dúvida, sairmos dos salões fechados, como chamávamos antigamente nossas casas, e nos apresentarmos em público.

Fry (1978) também defende essa imprensa ao escrever sobre a produção baiana, basicamente de autoria de Di Paula, conhecido em Salvador por seu trabalho como transformista. Este explica que, quando ele começou sua atividade "jornalística", por volta de 1962, os homossexuais da Bahia tinham uma vida muito "fechada", não podendo: "ter liberdade de expressão, viver publicamente e ser aceitos pela 
sociedade". Formaram-se, então, vários grupos exclusivos, com nomes como VID (Very Importants Dolls), Carimbos, e "Os Intocáveis". Di Paula começou a fazer um jornalzinho satírico, sobre os membros do seu grupo. Era chamado Fotos e fofocas, feito à mão (as "fotos" eram desenhos, com a tiragem de um exemplar único). Nestes desenhos, os membros do grupo eram transformados em mulheres "finíssimas" retratadas descendo de aviões intercontinentais, participando de coquetéis refinadíssimos ou simplesmente posando para a "câmara" de Di Paula. Como diz Fry, numa situação de forte repressão, Di Paula conseguiu produzir "um elemento de ligação e união, além da informação. Era uma forma de expressar a nossa realidade."

Fotos e Fofocas durou até 1967, quando, então, apareceu o Zéfiro, que já era datilografado. Em 1970, surgiu Little Darling, assim chamado em homenagem a um colega de Di Paula no curso de inglês. Este jornal era bastante diferente dos seus precursores, pois além das fofocas de turma, incluía crítica de teatro e de cinema, informes sobre os acontecimentos do "mundo gay" fora da Bahia e do Brasil, assim como informes que Di Paula achava importantes, mesmo se não diretamente relacionados à homossexualidade. Mais tarde, Little Darling mudou de nome para Ello - um saldo médio entre "ele" e "ela". Em 1980, veio Baby, também datilografado e com uma tiragem de 50 cópias xerografadas.

Fry (1978) relaciona as mudanças percebidas nos jornaizinhos às grandes transformações ocorridas na vida homossexual. Ele cita Di Paula (apud FRY, 1978):

Hoje a mentalidade é outra. E tem a liberdade enorme que nós não tínhamos antigamente. Nos carnavais éramos todos mascarados, não tínhamos coragem de mostrar a cara. Hoje, na Praça Castro Alves, todo mundo faz o que quer, abertamente e com o apoio de todo o mundo, com cobertura da polícia. Foi a década de 70 que trouxe esta renovação. Está relacionada com o movimento tropicalista de Caetano Veloso. Acho que esse pessoal todo é que criou uma abertura maior [...] Eu, na minha adolescência, pensava em sociedade, em fofoca, aquela coisa mais social. Hoje, mais maduro, vejo que tem muita coisa importante para se pensar, para pesquisar, saber as origens, buscar as raízes [...] Naquele tempo, achava lindo fazer um desfile de miss. Hoje, se eu fizer um desfile, como faço, é uma sátira. 
Fry (1978) conclui dizendo que, mesmo aqueles que criticam o trabalho de Di Paula como contribuidor para a manutenção do machismo, devem reconhecer que "o importante é que ele fez alguma coisa em prol da sua própria libertação e para a libertação dos outros”. Ele também chama a atenção para as várias transformações ocorridas na sociedade, transformações essas que levaram à possibilidade de se lançar o Lampião.

\section{A imprensa alternativa}

Uma das transformações importantes que ocorriam na época dava-se na imprensa, onde, desde a instalação do regime militar, um severo controle oficial era exercido sobre tudo o que se publicava. Para escapar dos rigores da censura e da autocensura, vigentes especialmente na grande imprensa, alguns jornalistas resolveram fundar pequenos jornais, de tiragem irregular, usando técnicas quase artesanais de impressão. Nascia, assim, a "imprensa alternativa" ou "imprensa nanica".

O grande pioneiro dessa forma de produção jornalística foi $O$ pasquim que começou a ser editado no Rio de Janeiro por volta de 1969. Nele não só se faziam críticas aos aspectos econômicos do regime, como também se promovia uma contestação cultural mais ampla, através do emprego ousado de expressões da gíria carioca e da mescla de discussões políticas com a "curtição" das belezas femininas. Não foi à toa que a escolhida "musa do Pasquim" foi Leila Diniz, uma atriz de cinema, defensora da liberdade sexual da mulher e dada a usar expressões, até então, consideradas impróprias a alguém do seu sexo. Também causou um pequeno escândalo ao se atrever a expor sua barriga de grávida, deixando-se fotografar de biquini na praia.

Apesar das posições do jornal frequentemente deixarem transparecer uma visão de mundo "machista", ele ousava tratar de forma irreverente assuntos raramente abordados pela grande imprensa de forma sisuda e altamente moralista. Usando uma linguagem informal, ele abordava o tema da homossexualidade e, durante certo tempo, até se referiu a um dos colaboradores como "a bicha do Pasquim". Ao misturar em suas páginas matérias de crítica social "sérias" com aquelas 
que tratavam de aspectos do não conformismo sexual, O Pasquim contribuiu para dar também a estes uma aura "política". Mais uma vez, repetia-se o processo em que a perseguição, promovida pela tirania do regime militar, acabava levando à união de vertentes de pensamento e prática bastante divergentes entre si. Forçados a conviver no estreito espaço permitido à oposição, os proponentes da crítica política e da crítica de costumes acabavam se influenciando mutuamente.

$\mathrm{Na}$ década de 1970, surgiu um grande número de jornais alternativos, dos quais, alguns dos mais importantes talvez tenham sido Opinião, movimento, Ex, Versus e Em Tempo. Através desses, certos segmentos do público - basicamente pertencentes à classe média intelectualizada - acompanhavam, em detalhes, os acontecimentos que marcaram o "despertar da sociedade civil" na segunda metade da década, como, por exemplo, as campanhas pela anistia para os acusados de cometer crimes políticos e pelo esclarecimento do paradeiro dos "desaparecidos". Não se pode esquecer o escândalo, causado pela publicação, no jornal Em tempo, edição 25 julho de 1978, de uma lista com o nome de 233 pessoas acusadas pelos presos políticos de serem torturadoras.

Além de terem que lutar contra a censura e de sofrerem constantes apreensões, às vezes de edições inteiras - o que para essas firmas de pequeno capital era um golpe seríssimo -, os jornais alternativos eram também muitas vezes vítimas de atentados terroristas. Mesmo assim, eles foram bem sucedidos em desempenhar um papel que a grande imprensa só foi capaz de adotar depois do advento da "abertura". Porém, com o acirramento da crise econômica e o consequente aumento dos custos da produção, assim como a onda de atentados terroristas às bancas que ousassem vendê-los, essas publicações começaram a deixar de circular. Com exceção do Pasquim, somente sobreviveram os jornais ligados às organizações político partidárias.

\section{Surge o "Lampião"}

Durante o período de maior proliferação dos "nanicos", surgiu um jornal que, com a mesma seriedade de propósitos oposicionistas dos demais, mostrou-se mais questionador da moral vigente, 
voltando-se para o público homossexual, considerado até então frívolo, apolítico, quando não doente ou decadente. Esse jornal, cujo nome oficial era Lampião da Esquina, para diferenciá-lo de uma editora paulista chamada Lampião, teve seu número zero publicado em abril de 1980. De acordo com seu "mito de origem", tudo começou com a visita ao Brasil, no final de 1977, do editor do Gay Sunshine, uma publicação americana dirigida a homossexuais. Winston Leyland viera para cá para entrar em contato com autores brasileiros, procurando contos para uma proposta de antologia da literatura gay latino-americana. O jornalista João Antonio Mascarenhas reuniu então um grupo de jornalistas para entrevistar Leyland para o Pasquim. Estes ficaram tão empolgados com a matéria que começaram a discutir a possibilidade de se lançar uma publicação que tratasse de forma séria a homossexualidade, destacando o seu contexto social. Realizaram-se várias reuniões e o grupo foi ampliado, para incluir alguns intelectuais que não haviam participado da reportagem para o Pasquim. As discussões serviram para revelar a existência de grandes diferenças de opinião entre os participantes, mas depois de algum tempo, estes resolveram deixar a teoria e passar à prática, produzindo o número zero, que saiu em abril de 1978.

Para financiar o jornal, nove dos seus onze idealizadores iniciais se cotizaram para criar uma editora de capital fixo. Resolveram também tentar arrecadar dinheiro através de uma carta endereçada a 12 mil amigos e amigos de amigos homossexuais de todo o Brasil. A receptividade que encontraram foi bastante boa e o dinheiro arrecadado serviu para financiar os dois primeiros números do jornal. Este, de formato tabloide, tinha vinte páginas e, começando com uma tiragem inicial de 10 mil exemplares, logo passou para 15 mil.

O número zero dedicava metade de sua segunda página a um editorial chamado "Saindo do gueto" e a outra metade a uma apresentação dos membros do conselho editorial. Estes dois textos revelavam bastante claramente as intenções que norteariam esse jornal durante certo tempo. Davam também uma indicação sobre o alto nível cultural e profissional dos seus responsáveis, o que, no futuro, daria ensejo a alguns dos seus detratores a chamá-los de "elitistas". 
Saindo do gueto

Brasil, março de 1978. Ventos favoráveis sopram no rumo de uma certa liberalização do quadro nacional: em ano eleitoral, a imprensa noticia promessas de um Executivo menos rígido, fala-se na criação de novos partidos, de anistia, uma investigação das alternativas propostas faz até com que se fareje uma 'abertura' do discurso brasileiro. Mas um jornal homossexual, para quê?

A resposta mais fácil é aquela que nos mostrará empunhando uma bandeira exótica ou 'compreensível', cavando mais fundo as muralhas do gueto, endossando - ao 'assumir' - a posição isolada que a Grande Consciência Homossexual reservou aos que não rezam pela sua cartilha, e que convém à sua perpetuação e ao seu funcionamento.

Nossa resposta, no entanto, é esta: é preciso dizer não ao gueto e, em consequência, sair dele. O que nos interessa é destruir a imagem padrão que se faz do homossexual, segundo a qual ele é um ser que vive nas sombras, que prefere a noite, que encara a sua preferência sexual como uma espécie de maldição, que é dado aos ademanes e que sempre esbarra, em qualquer tentativa de se realizar mais amplamente enquanto ser humano, neste fator capital: seu sexo não é aquele que ele desejaria ter.

Para acabar com essa imagem padrão, Lampião não pretende soluçar a opressão nossa de cada dia, nem pressionar válvulas de escape. Apenas lembrará que uma parte estatisticamente definível da população brasileira, por carregar nas costas o estigma da não-reprodutividade numa sociedade petrificada na mitologia hebraico-cristã, deve ser caracterizada como uma minoria oprimida. E uma minoria, é elementar nos dias de hoje, precisa de voz.

A essa minoria não interessam posições como as dos que, aderindo ao sistema - do qual se tornam apenas 'bobos da corte'- , declaram-se, por ledo engano, livres de toda a discriminação e com acesso a amplas oportunidades; o que Lampião reivindica, em nome dessa minoria, é não apenas se assumir e ser aceito - o que nós queremos é resgatar essa condição que todas as sociedades construídas em bases machistas lhes negou: o fato de que os homossexuais são seres humanos e que, portanto, têm todo o direito de lutar por sua plena realização, enquanto tal.

Para isso, estaremos mensalmente em todas as bancas do País, falando da atualidade e procurando esclarecer sobre a experiência homossexual, em todos os campos da sociedade 
e da criatividade humana. Nós pretendemos, também, ir mais longe, dando voz a todos os grupos injustamente discriminados - dos negros, índios, mulheres, às minorias étnicas do Curdistão: abaixo os guetos e o sistema (disfarçado) de párias.

Falando da discriminação, do medo, dos interditos ou do silêncio, vamos também soltar a fala da sexualidade, no que ela tem de positivo e criador, tentar apontá-la para questões que desembocam todas nesta realidade muito concreta: a vida de (possivelmente) milhões de pessoas.

Mostrando que o homossexual recusa, para si e para as demais minorias, a pecha de casta, acima ou abaixo das camadas sociais; que ele não quer viver em guetos, nem erguer bandeiras que o estigmatizem; que ele não é um eleito nem um maldito; e que sua preferência sexual deve ser vista dentro do contexto psicossocial da humanidade, como um dos muitos traços que um caráter pode ter. Lampião deixa bem claro o que vai orientar a sua luta: nós nos empenharemos em desmoralizar esse conceito que alguns nos querem impor que nossa preferência sexual possa interferir negativamente em nossa atuação dentro do mundo em que vivemos.

Em seguida, vinha outro artigo intitulado Senhores do conselho, onde era feita uma rápida apresentação dos onze responsáveis pela linha do jornal e de uma editora planejada para o futuro. Eram os jornalistas Adão Acosta, Aguinaldo Silva, Antônio Chrysóstomo, Clóvis Marques, Francisco Bittencourt, Gasparino Damata, João Antônio Mascarenhas, o pintor Darci Penteado, o crítico de cinema Jean-Claude Bernardet, o escritor e cineasta João Silvério Trevisan e o antropólogo Peter Fry. Nesse conselho de "senhores" não figurava nenhuma mulher. Na página 5 do primeiro número, um pequeno artigo de dois parágrafos, de autoria de Aguinaldo Silva, discutindo esse problema. Explicando que tudo começou com a visita de Leyland à coleta de material para uma antologia de autores homossexuais latino-americanos, a ser publicada sob o patrocínio do Congresso dos EUA, ele continua:

As mulheres editoras, procuradas por ele, reagiram de forma bastante estranha - não só deixaram bem claro que não estavam interessadas em participar da antologia, como algumas até se recusaram a falar com ele.

A ausência de mulheres em Lampião não é, fique bem explicado, por culpa do seu conselho editorial: convites não 
faltaram, todos recusados, mas nossas colunas continuam à disposição. Uma das questões que o jornal pretende levantar é a do feminismo e, pelo menos quanto a este tema específico, as mulheres homossexuais não podem se furtar; no caso das mulheres, a discriminação é bem mais complexa e independente de suas preferências sexuais.

De fato, o Lampião, durante os seus três anos de existência, publicou um número considerável de matérias relacionadas ao feminismo, várias delas com chamadas na capa. Discutia-se, por exemplo, as questões do aborto e do estupro, houve ampla cobertura do $1^{\circ}$ e do $2^{\circ}$ Congresso da Mulher Paulista e do Encontro Nacional de Mulheres de 1979, e o número dedicado ao $1^{\circ}$ Encontro de Grupos Homossexuais tinha na capa uma enorme foto de uma militante lésbica.

O assunto do lesbianismo mereceu bastante atenção - embora muito menos do que a homossexualidade masculina -, sendo o Lampião um dos grandes promotores da militância das mulheres homossexuais. Foram também publicadas matérias com chamadas na capa, discutindo a discriminação sofrida pela cantora negra Lecy Brandão e o caso de uma lésbica acusada de matar a sua amante.

Grande parte destes artigos foram escritos por mulheres, pois, Lampião, adotando os valores correntes da contracultura, pretendia dar a voz aos setores oprimidos da sociedade e às suas lutas políticas. Escreveram para Lampião intelectuais como Mariza Correa, Lelia Gonzales, Inês Castilho, Maria Luiza Heilborn, Cynthia Sarti; foram entrevistadas Marta Suplicy, Lecy Brandão, Alice Soares, Cassandra Rios, Norma Bengell, Darlene Glória, Zezé Mota, etc. Mas nenhuma destas se tornou uma colaboradora constante. A única mulher que participou de forma mais prolongada foi a poetisa e militante feminista Leila Mícolis, que acabou deixando o Lampião quando este se desentendeu com os grupos homossexuais, perto do final de sua existência. Portanto, apesar de não ter mulheres no seu conselho editorial, é necessário enfatizar que o jornal sempre se mostrou disposto a apoiar as lutas do movimento feminista, especialmente àquelas contra a esquerda stalinista ou instituições preconceituosas.

Voltando ao editorial, vemos que, desde o seu título, se enfatiza a necessidade de sair do gueto, visando deixar de lado a imagem 
padrão do homossexual como um ser amaldiçoado, incapaz de auto realização e que rejeita o seu sexo. Para isso, pretendia-se colocar os homossexuais como uma entre outras minorias oprimidas, todas com direito à sua voz, para poderem lutar por sua realização plena. Esse "dar voz às minorias" também incluiria falar livremente sobre o sexo. Reforçando a sua posição de colocar a discussão da homossexualidade dentro de um contexto social mais amplo, vemos também, neste texto, referências à situação política e cultural da época, com a menção à criação de novos partidos, à anistia e à "abertura".

Embora Lampião não tenha sido plenamente bem sucedido em sair do gueto, certamente procurou iniciar uma discussão sobre as outras "questões minoritárias". Além da atenção dada ao movimento feminista, deu grande destaque aos problemas da ecologia, dos negros, dos "presos comuns" e dos índios. Publicou vários artigos do ecólogo gaúcho José Lutzemberger, alguma coisa sobre os índios e bastante sobre os negros cuja luta contra a discriminação recebeu matérias de capa, incluindo uma longa entrevista com Abdias Nascimento e vários artigos de Rubem Confete sobre a vida e cultura negra.

Depois do movimento feminista, foram os negros os que receberam as maiores simpatias do jornal, principalmente no tocante às suas denúncias de arbitrariedades e violências policiais. Nestas, se revelava uma grande proximidade entre as dificuldades encontradas por eles e pelos homossexuais. A militância dos grupos negros foi tratada com bastante atenção e temas receberam coberturas de páginas inteiras, como as comemorações do dia de Zumbi e a inclusão de dados raciais ao censo da população nacional.

A questão da violência e das arbitrariedades policiais foi exaustivamente explorada e longos perfis foram traçados de dois delegados considerados especialmente agressivos: José Wilson Richetti, em São Paulo, e Geraldo Padilha, no Rio. Foi também feita uma campanha sistemática contra a proposta de oficialização da prisão cautelar e apontou-se a hipocrisia classista da campanha pela anistia ao preso político - geralmente de classe média - que não dava atenção à situação do preso comum - geralmente classe baixa - sujeito aos mesmos maus tratos e injustiças. Outra forma de atacar o moralismo da "esquerda bem pensante" foi a cobertura dada à prostituição, tanto 
feminina quanto a masculina, e à defesa das travestis, fazendo apologias a esses modos de vida.

Ao criticarem os poderes judiciais e policiais, a equipe redatora do jornal se mostrava muito bem informada. Não só contava com a coordenação editorial de Aguinaldo Silva, um conceituadíssimo repórter policial, mas, também, com a experiência própria dos membros do Conselho Editorial. Esses foram submetidos a inúmeros vexames durante o inquérito sofrido pelo jornal e promovido pelo Departamento de Polícia Federal do Rio de Janeiro, que pretendia enquadrá-los por ofensas à moral e ao pudor público. O Lampião desempenharia também papel importante na campanha dos grupos homossexuais, feministas e negros de São Paulo contra a Operação Rondão do Delegado Richetti, que pretendia retirar os homossexuais de seus pontos de encontro nas calçadas de certas ruas do centro da cidade.

Infelizmente, apesar desse empenho em manter as suas páginas abertas a outros grupos sociais, Lampião nunca conseguiu ser plenamente aceito como um jornal das minorias. A centralidade de seu foco em temas relacionados à homossexualidade emprestava-lhe um estigma que parecia por demais "contagiante", afugentando os segmentos heterossexuais de seu público potencial. Essa constatação, aliada ao considerável número de cartas de leitores que reclamavam contra os aspectos "militantes" do jornal, juntamente com as desavenças que acabaram surgindo entre o conselho editorial e os grupos homossexuais organizados, terminariam por levar ao seu abandono dessa temática e a uma maior ênfase nos assuntos do gueto.

Desde o seu primeiro editorial, Lampião já manifestara claramente a ênfase a ser dada à discussão da questão homossexual. Pretendia desmontar a imagem padrão do indivíduo que, sentindo atração física por outros do seu próprio sexo, seria um amaldiçoado, incapaz de auto realização e com tendências a rejeitar a sua sexualidade. Portanto, sempre houve uma intenção de falar livremente a respeito de sexo, ridicularizando os tabus sociais e ressaltando os seus aspectos criativos e prazerosos.

Resgatou-se a linguagem do gueto, com um uso constante de termos até então considerados palavrões, como "bicha", por exemplo. Muitas matérias foram dedicadas às possibilidades de prazer, 
escondidas nas ruas, nas praias e outros locais do Rio e do Brasil, discutindo-se assuntos como “caçação", prostituição, etc. Geralmente, esses temas eram tratados de forma jocosa e bem humorada. Um bom exemplo disto foi a publicação da coluna Bixórdia, em que, todo mês, eram feitos comentários rápidos e, por vezes, maldosos a respeito de eventos ou personalidades em destaque no mundo gay. Nessa coluna, aparecia um personagem fictício de sexo ambíguo chamado de Rafaela Mambaba, possuidora de uma língua ferina, do tipo normalmente atribuído a travestis e "bichas loucas".

O que vem a ser bixórdia? Está no dicionário da Mestra Mambaba, s.f.: em machês, palavra originária de 'bicha' s.i. (substantivo indefinido) somada a 'mixórdia' s.f.: mistura, bagunça. Representação do que é livre, auto permitido. Tudo é sério, nada é triste. Paradoxo vivo (finíssimo, adorei) em que se misturam viados, bichas, perobos, tias, primas, entendidos, gueis, transadores, mariconas, paneleiros, frescos, frutas e xibungos. Por ex.: vale tudo, né queridinhas? ${ }^{2}$

A atitude irreverente, atribuída ao homossexual, se refletia em certas entrevistas, feitas com personalidades importantes da vida política ou cultural, onde o entrevistado poderia ser descrito como sendo "um gatão", com possíveis comentários até ao tamanho de sua "mala".

Implícita ou explicitamente, fazia-se uma campanha pelo "se assumir". No número dois, havia, por exemplo, um artigo, de João Antonio Mascarenhas, enumerando as razões para se adotar essa postura. Mascarenhas define o "assumir-se" como "o processo de aceitar com naturalidade a condição de homossexual, sem alardeá-la, mas sem escondê-la”. Em seguida, apresenta-se como razão para a adoção dessa atitude perante a vida: a desobrigação da hipocrisia, da mentira e do medo de ser descoberto, que exporiam os homossexuais a chantagens de todos os tipos. Essa atitude também serviria de encorajamento para outros homossexuais se revelarem e ajudaria na construção de um mundo melhor, onde os direitos humanos e os das minorias seriam respeitados. Para Mascarenhas "o assumir-se constitui um ato essencialmente político, através do qual o indivíduo

2 Lampião, p. 12, out. 1978. 
reconhece-se como integrante de um grupo oprimido, primeiro e indispensável passo para lutar contra a opressão". Reconhecendo que muitos "opressores machistas" reagiram a essa prática de se assumir, ele faz a seguinte ressalva: em várias ocasiões, a fúria punitiva é tal que somente cada um de nós, individualmente acha-se habilitado a decidir quando e como poderá arcar com as consequências de uma ostensiva rejeição dos preconceitos dominantes. ${ }^{3}$

Como já foi dito anteriormente, não havia consenso entre os membros do conselho editorial sobre quase nenhum assunto e a questão do "se assumir" era um dos mais polêmicos. Algum tempo depois, tanto Peter Fry quanto Jean-Claude-Bernardet publicaram os já citados artigos em que diziam preferir evitar assumir identidades muito rígidas. Aludindo a uma declaração feita, pouco tempo antes, pelo então Ministro da Educação e Cultura, Eduardo Portela, sobre as probabilidades de sua eminente demissão daquele ministério, Fry fez um jogo de palavras e falou em "ser ou estar homossexual?" Mas a questão do "assumir" a homossexualidade, como se esta fosse algum tipo de essência pré-determinada do indivíduo, encontrava muitos ecos no meio homossexual. Tornou-se uma das preocupações implícitas em vários grupos de militantes, como o Somos de São Paulo, por exemplo, no qual, durante certo tempo, era grande a preocupação em "esvaziar" as palavras "bicha" e "lésbica", através de seu uso corriqueiro e não pejorativo, como forma de auto designação.

Embora o jornal reforçasse a necessidade de "se assumir" - sendo o próprio ato de ir a uma banca de revista e comprar o Lampião uma maneira de fazê-lo - ele sempre deixou em aberto qualquer tentativa de explicação da etiologia dessa condição. Darcy Penteado, por exemplo, no seu artigo intitulado Homossexualismo: que coisa é essa?, reconhece a impossibilidade de "ajustar o homossexualismo a uma exata classificação genética, endócrina ou psíquica”. Segundo ele, na impossibilidade de "curar", os psiquiatras trabalham no sentido de ajustar os pacientes à sua homossexualidade, o que é difícil, devido à intolerância da sociedade. Por causa dela, os homossexuais seriam

3 Lampião, p. 2, jun. 1978 
obrigados a "viver em mutismo à sua verdade" ou então a se restringirem aos limites do gueto. Isso levaria a maioria a desejar ser "normal" e a recalcar seus sentimentos verdadeiros durante toda a vida, numa tentativa de condicionamento nessa "normalidade". Darcy Penteado afirma concordar com a noção de Marc Oraison de que "o homossexualismo é um fato" e continua:

Mais do que um fato, o homossexualismo é condição humana. E como tal, mesmo sendo atributo de uma minoria, está exigindo o seu lugar atuante numa sociedade, com o direito a uma existência não mistificada, limpa, confiante, de cabeça levantada. Porque só a tolerância, como foi dada até agora, não obrigado! É muito pouco. ${ }^{4}$

Essa convicção parece ter sido geralmente compartilhada, não só pelos outros membros do corpo editorial do jornal, mas também por grande parte dos seus leitores. Mesmo constatando as dificuldades de se determinar uma base biológica para a homossexualidade e enfatizando os aspectos arbitrários e relativos das normas sexuais, o jornal sempre falou sobre os homossexuais como uma categoria com interesses e direitos em comum, além de ser uma minoria oprimida. Mas, como já foi dito, a posição política do Lampião suscitava muitas discordâncias entre seu público. Uma carta publicada dois números depois e assinada por Gide Guimarães demonstra isso. Criticando a postura indecisa do jornal, que tenderia a torná-lo "um nanico muito chato", ele continua:

O assumir-se (do artigo de João Antonio Mascarenhas) diante das regras do jogo opressor, enfatiza uma tradição de uma sociedade repressora que nos impõe uma rasgada de sedas para definir melhor o seu comportamento com a gente? Não seria o Lampião uma propriedade privada de uma elite que quer ser lida "do Oiapoque ao Chui" numa operação aspirina? Eu particularmente prefiro um jornal que abra abcessos. Gere câncer. E a família desta TFP não seria a obviedade de cristalizar o gueto de que falam libertar?

4 Lampião, p. 2, jun. 1978. 
Ele acusa os redatores do jornal de paternalismo e de serem "bichas esclarecidas que tentam compreender e unir suas vozes às das outras minorias ao seu redor". Ao mesmo tempo, o Lampião continuaria a fomentar o estereótipo de que os homossexuais seriam mais sensíveis, artísticos e inteligentes. Antes de concluir dizendo que a ideologia no jornal se parecia com a do "social-democrata-cristão Jornal do Brasil", o leitor questiona: Se os operários do metrô ou do $A B C$ paulista se juntam às bichas (isto é, se eles não as caparem antes), em que é que vai dar? num prá frente Brasil? ${ }^{5}$

Além de questionar a posição indefinida do Lampião, essa carta também chama a atenção pela violência da linguagem empregada. Isso refletia o tom altamente emotivo, constante nos debates dentro do movimento homossexual, onde a expressão direta dos sentimentos era muitas vezes mais valorizada que exposições que privilegiavam a frieza da lógica e da teoria. Além de ser mais “espontâneo", era mais fácil, especialmente por conta da quase inexistência, no Brasil, um discurso homossexual mais elaborado. Tal mensagem, também reflete uma tradicional ambivalência a respeito das classes baixas por parte dos homossexuais, em cujas fantasias o operário figurava como o próprio símbolo do macho desejado e temido. (PERLONGHER, 1987)

Embora essas críticas, a um certo tipo de conformismo indeciso e à reprodução de estereótipos, tivessem fundamento em relação a algumas matérias, elas não poderiam ser compreendidas como dirigindo-se aos artigos escritos por João Silvério Trevisan, um dos mais dedicados "lampiônicos" de São Paulo e liderança importante no Somos-SP. Como o missivista Gide Guimarães, ele também era a favor da "abertura de abcessos" e da geração de "cânceres" no corpo político e social. Sua argumentação principal era dirigida contra o poder. Procurava outras formas, assumidamente utópicas de organização e luta, que não resultassem simplesmente em novas estruturas de poder, como as que teriam surgido na União Soviética, por exemplo.

Podemos ter um gostinho da sua retórica carismática e inflamada lendo o seu artigo. "Por uma política menor: bichas e lésbicas

5 Lampião, p. 17, ago. 1978 
inauguram a utopia”. Lá, ele afirma ser necessário subverter a própria "subversão" e a sua institucionalização, criticando os partidos, por serem manipuladores e doutrinários. Trevisan também rejeita a ideia de se procurar salvação no herói/patrono de qualquer tipo "seja ele Lenin, Trotsky, Bakunin, Papa ou Lula”, pois heróis implicariam em dogmas, militantes e guerras pelo poder. Para realizar a utopia, seria necessário desenvolver as individualidades:

Partir de nossas individualidades para transformar - porque só somos verdadeiramente proprietários de nós mesmos. Daí, ser o indivíduo subversão à vista, nossa infinita variedade impulsiona uma invenção contínua e exige o novo. Então estaremos colocando imaginação, mistério e ambiguidade na política, considerada terreno da ciência. E inseriremos nosso corpo, cabeça, conceitos, quotidiano, a loucura de cada um no turbilhão das transformações. E, como a individualidade é o terreno do improvável, estaremos adentrando o universo da poesia onde, ao contrário da militância, tende-se a abolir a doutrina e a normalidade. Resta encontrar nossa perdida poesia: talvez num vago gesto desmunhecado ao dobrar a esquina, no bilhetinho descabelado de paixão abandônica, no traje cafona da bichita orgulhosa de estar falando em público, na peruca velha que o travesti ganhou (ou roubou?) da patroa, nos fins de semana dormindo em grupo com as lésbicas, nas fantasias de trepar com o pai ou a mãe, nas tantas fantasias engolidas. Estamos misturando integrantes pouco usuais. Nossos.

O paraíso acabou, viva a utopia.

Direitas e esquerdas do sistema estão querendo tornar-nos consumidores de homossexualismo, e com isso recuperar-nos. Trata-se de uma forma de nos iludir com o poder, a neutralizar o potencial subversor. A única maneira de garantir nossa subversão e impossibilitar essa recuperação é ser cada vez mais viado e sapatona, portanto mais malditos e menos cobiçados por todas as formas de poder (ordem), do tipo partidos, publicidade, família, mídia. Quanto mais aprofundarmos nossas diferenças com a normalidade instituída (a sociedade heterossexual compulsória), tanto mais difícil será nos digerir. E tanto maior será nossa capacidade de virar a mesa.

Concluindo, ele diz que a luta pelo poder é "a luta da memória contra o esquecimento". Não se deveria esquecer o desencanto com ídolos, evitando-se a recriação de novos heróis, mesmo que sejam a 
“Travesti Mártir", o "Viado Padrão" ou a “Grande Sacerdotisa Lésbica”. Seria também necessário deixar de lado os "antigos manuais que dividem o mundo em bandidos(as) e mocinhos(as)". Ao invés da busca de um paraíso que não existe, porque nele tudo está resolvido, Trevisan propõe: "Botar a cabeça em altíssima velocidade para inventar o máximo possível, a utopia". ${ }^{6}$

Nesse trecho, surgem vários temas e até expressões literárias que tiveram grande repercussão nas discussões travadas dentro dos grupos homossexuais. Embora a influência de Trevisan fosse maior em São Paulo, onde residia e militava, a distribuição do Lampião pelo país inteiro assegurou a divulgação de suas ideias em nível nacional. Seu tema constante era a necessidade de se "subverter a subversão", abandonando a fé em "respostas prontas" ou "cartilhas", incapazes de dar conta das perpétuas mudanças que ocorrem no mundo real. O foco de toda a subversão, segundo ele, é o indivíduo, "terreno de improvável", "universo da poesia". O grande perigo seria a "recuperação" da individualidade, por parte da sociedade consumista autoritária e a única forma de evitar isto seria exacerbar aqueles aspectos mais indisciplinados e renitentes à massificação ou definição, como o desejo e a anarquia.

Essa visão, individualista libertária, embora raramente expressa com mais talento do que fazia Trevisan, era na época bastante corrente entre certos setores intelectuais e estudantis. Uma forma de tentar entender a ubiquidade dessa postura é sugerida pelo trabalho de Louis Dumont, que tem estudado o individualismo como sistema de representações dominantes nas sociedades modernas. Contrastando estas com as tradicionais ou hierárquicas, na qual a totalidade social é enfatizada às custas dos indivíduos biológicos, ele diz que, no Ocidente, predomina uma contínua fragmentação do todo social e o surgimento de domínios crescentes autônomos. Traçando a trajetória da ascensão dessa ideologia, onde a representação da totalidade é deslocada para o indivíduo, ele destaca alguns eventos como cruciais à sua consolidação, como o Luteranismo, a Declaração dos

6 Lampião, p. 10, jun. 1980. 
Direitos do Homem, a Revolução Industrial e a constituição do Estado Burguês. Esses eventos são tomados como importantes, pois sinalizariam a entrada em vigor, em determinados domínios, da prevalência do indivíduo sobre o social. (DUMONT, 1972)

A intensidade do individualismo não é a mesma nos vários movimentos citados, pois cada um tem suas especificidades. A consolidação do individualismo, como corpo de representações dominantes, implica em um processo de fragmentação contínua e incessante, em uma autonomização de esferas. Franchetto e outros chamam a atenção para o fato de que o feminismo viria a representar mais um desdobramento dessa ideologia individualista, investindo sobre um dos domínios mais resistentes à destotalização: a família. Embora levantando questões de natureza distinta, os movimentos de libertação homossexual também se colocam ao lado do feminismo, elaborando novas identidades sexuais, subtraindo a sexualidade, à família e a constituindo como domínio autônomo, totalmente independente da reprodução da espécie. (FRANCHETTO, 1981)

A luta feminista, porém, não se restringe somente à preocupação com a autonomia da sexualidade feminina, dedicando uma grande, se não a maior, parcela de seus esforços para consolidar a cidadania das mulheres. Existe uma acentuada defasagem entre os processos de individualização dos dois sexos. A identidade masculina já se encontra fortemente ancorada na esfera pública, no trabalho, na política, etc., enquanto as mulheres só recentemente começaram a se emancipar do domínio exclusivo da família, passando também a exigir igualdade de condições no trabalho e na educação. Portanto, o feminismo, ou mesmo a sua expressão menos elaborada presente no senso comum das mulheres contemporâneas, abrange uma vasta gama de questões. Mesmo ao tratar da sexualidade, a nova contestação feminina não pode deixar de levar em conta os problemas levantados pelo potencial reprodutivo de sua prática heterossexual, o que inevitavelmente leva à necessidade de abordar temas pertinentes ao futuro do conjunto da sociedade. Consequentemente, a consolidação da plena individualização feminina requer um certo grau de solidariedade grupal e uma identificação com mulheres oriundas de um amplo espectro social com reivindicações múltiplas. 
Já os homossexuais, embora frequentemente agredidos em seus direitos humanos, são menos presos a essa identidade, que se revela parcial e variável no tempo e no espaço. Grande parte deles podem utilizar a tática do passing e assegurar os seus direitos de cidadãos, manipulando sua identidade de forma quase impossível às mulheres, para quem é muito mais difícil "virar homem". Para os homossexuais, a questão se coloca de forma ainda mais individualizante e, como vimos no próprio texto de Trevisan, há uma rejeição por novas categorias de heróis culturais, mesmo que homossexuais.

Outro ponto em comum desses vários grupos era uma visão de poder que hoje chamaríamos de "foucaultiana", ainda que na época a obra do filósofo francês fosse menos conhecida e as origens da ideia provavelmente fossem outras. O poder era pensado como difuso na sociedade, mais do que concentrado principalmente no Estado ou nos grandes conglomerados financeiros. Ele era vislumbrado como também atuante nas relações interpessoais, onde sua contestação tomava-se igualmente importante. Assim, buscavam-se formas de organização ultra democráticas e, quando algum tipo de liderança fosse imprescindível, procurava-se dar a ele um caráter temporário e rotativo. A atribuição do "discurso competente" a determinados tipos de peritos era evitada e as opiniões de militantes de grande experiência e conhecimento teórico eram formalmente igualadas às dos menos experientes, mesmo quando, na prática, essa pretendida homogeneização não tivesse o sucesso almejado.

Ao contrário de Foucault, os militantes acreditavam que o poder era nocivo em si e poderia ser superado. Portanto, para eles, nada podia ser pior do que uma luta pelo poder e a pior acusação que se fazia, a respeito do funcionamento dos partidos e de outras instituições, era a de que ambicionavam conquistar o poder.

Trevisan, no seu papel como um dos principais ideólogos do movimento homossexual e do Lampião, teve uma atuação muito importante na difusão dessas ideias e uma das suas grandes preocupações era a de retirar do proletariado o privilégio de ser a grande força revolucionária:

Desmistificar a hegemonia transformadora do proletariado significa quebrar os limites e colocar como agentes de transformação também os loucos, os velhos, as crianças, a luta 
ecológica, os índios, os negros, os homossexuais, as mulheres, as putas - enfim, todos aqueles blocos de especificidades que caminham contra a corrente. Isso irá dificultar as formas hegemônicas, o controle do poder por uns poucos. Pois é mais fácil controlar uma classe revolucionária do que centralizar dezenas de blocos de transformação e apossar-se de tantas definições divergentes. Então, quero desafinar, passar os parâmetros da política para a margem: ficar pelado nas reuniões sérias, destampar nossas mais recônditas fantasias, desprogramar-nos sexualmente (a promiscuidade como elemento subverso), lutar junto com as classes proletárias pelo seu direito ao prazer, e não apenas ao trabalho. ${ }^{7}$

Para Trevisan (apud ZUCHA, 1980), uma mudança real somente seria possível através da ênfase na importância das "questões marginais", associadas a personalidades incômodas; conforme disse a um entrevistador:

O 'marginal' que eu uso é um oprimido fora das cartilhas que definem o que é oprimido: no caso, por exemplo, a classe operária, a única grande definição de oprimido que as esquerdas patriarcais ortodoxas dão. Na medida em que você se propõe, como novo tipo de oprimido, você abre caminho para todos os oprimidos que virão atrás de você, para quem quiser dizer: 'Eu sou oprimido'. E, no fundo, cada indivíduo tem a sua especificidade de opressão. Você está colocando as individualidades na transformação, no movimento, no processo de transformação social. Já não é mais uma transformação vinda de baixo para cima, ou seja, do geral para o particular, mas ao contrário, é do particular para o geral. Então, é, na medida dessa compreensão teórica do problema da opressão, que esses grupos tão diversos, e que brigam para manter sua diversidade, irão se entender, se tornarão solidários... A liberdade a partir da diferença, que é a individualidade, compreende? Não é um programa fácil [...]. Nós estamos lutando contra a massa [...].

Segundo essa concepção, a forma de fazer militância também deveria ser diferente. Nisso, retomava-se uma tradição de luta política dos adeptos da contracultura que, durante a campanha contra

7 Lampião, p. 9-10, jun. 1980 
a guerra do Vietnã, por exemplo, fizeram um ritual de exorcismo em volta do Pentágono. O movimento feminista adotou, também, a prática de distribuir flores em suas manifestações e os grupos homossexuais, em suas atuações públicas, adotavam um comportamento "fechativo" - estereotipadamente escandaloso e efeminado. Isso também era encorajado por Trevisan, que na sua luta contra o poder considerava o hedonismo um dos seus principais aliados:

Para questionar o militantismo sisudo, temos nas mãos, ao
menos potencialmente, fatores inegáveis como a cama e suas
variantes, esse espaço para o nosso desejo. E entenda-se por
cama tudo o que esteja relacionado com prazer, corpo, sexu-
alidade, quotidiano, nível pessoal, etc. Por ser lúdica, gratui-
ta, irresponsável e farta em invenções, a cama pode relativi-
zar o poder. É verdade que frequentemente o poder relativiza
a cama, sempre que esquecemos nossa sexualidade em favor
da militância sobre sexualidade. E, no entanto, a melhor ma-
neira de afirmar nosso direito ao prazer é fazendo boa cama,
contra a chatice de nossos discursos militantes. Não poderia
ser essa uma das nossas contribuições, em termos de práxis
política? Uma forma subversora e herética, na medida que
estaremos misturando elementos desconcertantes e criando
misturas novas?8

Ao contrário do proposto no primeiro editorial do Lampião, no qual se pretendia desmentir a imagem do homossexual como amaldiçoado por sua preferência sexual, Trevisan parece se felicitar com a maldição, para ele a marca real da individualidade subversiva. "Não peço que me aceitem, porque eles não são capazes de aceitar tudo o que eu quero que seja aceito em mim. Acho que sou inaceitável”. (TREVISAN apud ZUCHA, 1980)

Coerente com essas posições, Trevisan - e aqui ele parece refletir um consenso entre os membros do conselho editorial - era contra o Lampião se render a algum tipo de "consumismo", tanto de direita como de esquerda. Por esta expressão, pretendia-se alertar para o perigo de massificação, implícito em qualquer modismo. Em relação à esquerda, um consumo da questão homossexual iria implicar numa

8 Lampião, p. 9, jun. 1980 
moderação da linguagem e num maior controle sobre a "desmunhecação", para permitir sua melhor digestão.

Eu tenho sérias dúvidas quando Movimento publica uma matéria sobre o homossexual [...]. De repente, é um assunto que está se tornando moda, está se tornando quase uma obrigação para as cartilhas progressistas... Então, é uma forma de se manter na crista da onda, para que você continue vendendo, não só jornais, mas ideias... É a ideia do poder, o poder você não atinge só através do capital, você objetiva esse poder inclusive tentando impor suas ideias. Então, eu tenho muito medo, quando esses jornais começam a publicar coisas sobre o homossexual que sejam consumidas, inclusive como uma forma de se modernizar o papel deles para não mudar nunca. (TREVISAN apud ZUCHA, 1980)

Apoiados nesse tipo de pensamento, Trevisan e outros membros do conselho editorial mais ativamente envolvidos na feitura do jornal - Aguinaldo Silva, Francisco Bittencourt e Darcy Penteado - começaram a atacar a militância homossexual. Diziam que certos militantes estariam interessados em usar esse movimento para "fazer a cabeça” de seus participantes e levá-los a se engajarem em agremiações político-partidárias, como o PMDB ou a Convergência Socialista. A partir disso, o Lampião entrou em conflito com o Grupo de Atuação Homossexual de Olinda - GATHO, um grupo que teve uma atuação bastante grande no Nordeste - e o Somos - Auê, do Rio de Janeiro. Em São Paulo, o jornal teve um papel importante no "racha" que o Somos sofreu, devido especialmente à "dupla militância" de Trevisan, que atuava tanto no grupo quanto no periódico. Esse episódio será tratado em mais detalhes em outro capítulo.

Embora, durante a maior parte de sua existência, o Lampião tenha defendido e promovido a militância, a partir de um determinado momento na posição do jornal, tornou-se francamente agressiva em relação aos grupos. Suas manchetes e artigos que publicava serviram para divulgar, pelo país inteiro, uma grande desconfiança a respeito de qualquer política homossexual. Assim, seu papel no processo de desintegração do movimento homossexual foi considerável. Em uma época em que as recordações das arbitrariedades cometidas pela ditadura ainda estavam frescas, houve também uma série de acusações 
de que o jornal estaria usando o seu poder para "entregar" profissionais, cujos empregos corriam risco se sua identidade homossexual se tornasse pública, ou ainda, estrangeiros que seriam passíveis de deportação se sua participação em grupos de esquerda, oficialmente proscritos, fosse alardeada.

Grande parte dessa agressividade foi devida, provavelmente, às desavenças pessoais e políticas de Trevisan, Aguinaldo Silva e Francisco Bittencourt com integrantes do movimento homossexual do Rio, e de São Paulo especialmente. Isso somado às ideias "anarquistas" - para usar um termo repudiado pelo jornal -, ou antileninistas, veiculadas pelo Lampião, lhe valeu a pecha, por parte de alguns, de ter se tornado um "jornal de direita". De fato, inúmeras matérias foram publicadas denunciando o machismo e o conservadorismo da esquerda. O número de fevereiro de 1981, por exemplo, tinha em sua capa uma caricatura de Fidel Castro, em que aparecia barbudo e vestido como Carmem Miranda. De sua boca saía um balão com os dizeres: "Yo no creo en maricones, pero que los hay, los hay". No interior do jornal, uma reportagem de seis páginas detalhava a perseguição aos homossexuais movida pelo regime revolucionário cubano. Porém, em outros números, havia também sido denunciada a repressão sexual na Argentina, Chile e outras ditaduras direitistas, além de serem constantes as referências às arbitrariedades do sistema brasileiro. Estas iam, por exemplo, desde vagas acusações de corrupção contra os Atallas, Lutfallas e Ludwigs cuja impunidade, apesar dos escândalos financeiros, era contratada com os vexames infligidos aos membros do conselho editorial durante o inquérito sofrido pelo jornal, a críticas dos sistemas judiciário e carcerário, acusações contra um síndico autoritário que hostilizava uma travesti que morava no seu prédio, etc.

A ousadia do periódico não poupou nem a Igreja. Em julho de 1980, por ocasião da visita papal, quando só se viam elogios ao pontífice na imprensa, foram publicadas quatro páginas sobre os aspectos sexualmente repressivos dos dogmas católicos. A capa carregava uma caricatura de Cristo na cruz, rodeado por sinistras figuras paramentadas como bispos. Acima da cabeça do crucificado, ao invés do tradicional "I.N.R.I.", uma placa com o dizer Homossexual. O número seguinte relatou a experiência de integrantes do Grupo Homossexual de Brasília, 
Beijo Livre, que haviam tentado entregar pessoalmente ao papa uma carta, criticando o seu posicionamento contra a atividade homossexual.

Os conflitos em que o Lampião se viu envolvido foram inúmeros e de todos os tipos: políticos, econômicos, pessoais, estéticos, etc. Mais do que os erros de uma determinada política, eles refletiam a grande diversidade de opiniões existentes, não só na redação do jornal, mas também entre o seu público leitor. Esse era sabidamente heterogêneo em termos de classe, cultura, idade, ideologia política, localização geográfica, etc. Entre os "lampiônicos" acusados de "direitismo", alguns possuíam um considerável currículo de militância oposicionista e era com base nessa experiência que faziam suas críticas à esquerda. $\mathrm{O}$ ocasionalmente vitriólico Trevisan, por exemplo, militou na Juventude Operária Católica e na Juventude Universitária Católica, que depois virou a Ação Popular, onde ele rachou com a linha do PC soviético para se tornar um "maoísta político", como diz. Em suas viagens, conheceu a Alemanha Oriental e a Tchecoslováquia, onde ficou horrorizado com a repressão vigente. Durante sua estada nos EUA, conheceu também vários estudantes radicais, entre eles, Charlie, um rapaz trotskista, que veio ao Brasil encorajado por ele. Este iria, mais tarde, se tomar seu grande adversário, ao liderar uma facção acusada de tentar "atrelar" o Somos-SP à Convergência Socialista.

Aguinaldo Silva era outro membro do conselho que, ao atacar os preconceitos, agia com conhecimento de causa. Desde o golpe militar de 1964, ele tivera problemas com a repressão política, tendo sido forçado a abandonar Recife naquele ano, por trabalhar no jornal Última hora do Nordeste, cuja linha fora considerada demasiadamente radical. Passou quarenta e cinco dias incomunicável numa cela do presídio da Ilha das Flores, onde fora mandado pelo Centro de Informações da Marina (CENIMAR) por ter escrito um prefácio para o diário de Che Guevara. Uma vez libertado, chegou a trabalhar no Opinião e no Movimento. Durante esse tempo, pôde ver a pouca importância dada, pelos radicais de esquerda, ao tema da sexualidade e a forma com que se tentava silenciar qualquer referência à homossexualidade. Conta como, uma vez, escreveu crítica favorável ao livro "Amor entre mulheres" para Opinião. Ele havia gostado desta obra da psicanalista Charlote Wolff, porque nela se falava de homossexuais de 
forma aberta e sem culpabilização. Porém, segundo diz, o editor do jornal, Raimundo Pereira, se colocou contra o livro, justamente por essa razão. (SILVA, 1981)

Relatos de experiências negativas desse tipo são frequentes entre homossexuais e mulheres com vivência política esquerdista tradicional e, até hoje, grande parte das organizações tratam com hostilidade qualquer reivindicação baseada na sexualidade, como mostram Fernando Gabeira e Herbert Daniel, entre outros.

Depois de um começo auspicioso, com muitas vendas e recebendo apoio de diversas áreas identificadas com as lutas das chamadas "minorias", Lampião começou a sofrer um sério desgaste. Outras publicações voltadas para o público homossexual surgiram, como a revista Rose, por exemplo. Aproveitando a maior tolerância das autoridades na área de costumes, começaram a ser editadas revistas sem nenhuma pretensão cultural ou política, mas dispostas a preencher suas páginas com fotos de nus masculinos. Alguns dos conselheiros do Lampião, em função de seus princípios políticos de seriedade anticonsumista, ou então temerosos de enfrentar novos dissabores com o inquérito policial, se colocaram contra o uso de nus para aumentar as vendas do jornal, levando a novas dissenções internas e finalmente à demissão de um dos "senhores do Conselho".

Além disso, existiam outros fatores de desagregação interna. Desde o início, surgira uma rivalidade entre os conselheiros residentes em São Paulo e os do Rio. Originalmente, planejara-se alternar as reuniões de pauta entre as duas cidades, mas isso logo se mostrou impossível e, aos poucos, o jornal ficou cada vez mais sob a responsabilidade e direção de Aguinaldo Silva e Francisco Bittencourt, no Rio. Isso, inevitavelmente, levou a desentendimentos, especialmente entre Trevisan e Aguinaldo Silva. Este era acusado de não abrir espaço suficiente para artigos vindos de São Paulo, fazendo com que o jornal ficasse quase exclusivamente voltado para os acontecimentos do gueto homossexual carioca. Não eram somente os paulistas que reclamavam. Como o jornal tinha uma distribuição nacional, leitores de outros estados escreviam cartas criticando o espaço excessivo dado a matérias sobre o Rio.

As desavenças internas e as brigas com os grupos homossexuais e de esquerda eram refletidas nas páginas do jornal, que tinha, como 
política, publicar as principais cartas críticas que recebia, embora, muitas vezes, juntando uma resposta desaforada. As notícias sobre o ativismo das minorias também eram pouco alentadoras. Vários números estampavam manchetes de capa como: "A esquerda joga bosta nas feministas", "Bichinhas sonhando com o poder" ou "Mais tesão e menos encucação". Chegara ao fim o messianismo que caracterizara suas fases iniciais, com referências ao Encontro Nacional do Povo Gay ou Homossexuais a Nova Força. A isso se somou uma onda de terrorismo de direita que, durante alguns meses, quase conseguiu acabar definitivamente com a imprensa alternativa, ameaçando queimar todas as bancas de jornal nas quais os "nanicos" estivessem à venda.

Para aumentar as dificuldades, o preço do papel começou a disparar e os custos de produção ameaçavam tornar o jornal inviável. As vendas caíram. Outras formas de manter o Lampião, através de venda de espaço para anúncios ou pela edição de livros, também se frustraram. A orientação explicitamente homossexual afugentava anunciantes e criava resistências entre as grandes distribuidoras, como Fernando Chinaglia, que se recusava a trabalhar com o Lampião, tornando muito mais difícil a sua divulgação em nível nacional.

Os últimos números do jornal começaram a refletir cada vez mais a convicção de Aguinaldo Silva, de que não se estava oferecendo o produto que o mercado queria e que o ativismo só apelava à minoria de uma minoria. Mas, apesar de começar a dar mais ênfase às reportagens sobre temas como masturbação, prostituição, travestis, etc., o jornal não conseguiu aumentar suas vendas. Em junho de 1981, saiu seu último número, o 37.

Sobreviveram várias outras publicações mais amenas. O próprio Aguinaldo Silva lançou seu Homo-Pleiguei, de duração efêmera. Aos poucos, foram desaparecendo do mercado todas as revistas dirigidas ao público homossexual, que publicavam notícias e artigos além de fotos de nus. Hoje imperam revistas declaradamente pornográficas, títulos como Macho Sex, Sex Gay, Narciso ou Marilyn Monroe, de impressão barata, mas contendo fotos nas quais se veem, em detalhe, relações sexuais entre duplas ou grupos homossexuais.

Em uma entrevista que concedeu ao Pasquim em 1981 Aguinaldo Silva afirma: “[...] o Lampião foi a coisa mais importante que surgiu na 
imprensa brasileira dos últimos cinco anos. Depois do Pasquim não pintou nada de extraordinário até o Lampião, um jornal louquíssimo. Agora que ele parou é que as pessoas vão refletir sobre sua importância". (A PALAVRA..., 1981)

Relendo os números antigos daquele jornal e vivendo nos últimos anos da década de 1980, quando mesmo as publicações mais estimulantes e irrequietas raramente ousavam se desviar do liberalismo bem comportado, tem-se a impressão que Aguinaldo Silva tinha bastante razão. Certamente, no tocante ao desenvolvimento de uma discussão constante da homossexualidade, só nos resta hoje recorrer às revistas pornográficas americanas, vendidas em profusão em milhares de bancas de jornais no país inteiro. 


\section{A fundação do Grupo Somos}

\section{A pré-história}

No Brasil, a formação de grupos de homossexuais não é nenhuma novidade e vem ocorrendo há muitas décadas. Tradicionalmente, porém, suas festas, concursos de miss, a produção e distribuição de jornaizinhos artesanais, etc., tinham, até nos últimos anos da década de 1970, como único objetivo, a diversão e seus aspectos críticos que se limitavam à bem humorada paródia dos acontecimentos mundanos da alta sociedade. As reuniões desses grupos geralmente tinham um caráter clandestino e aconteciam em locais fechados para evitar manifestações de agressividade por parte da sociedade maior. Embora a homossexualidade não fosse considerada crime pelas leis brasileiras, era comum a perseguição policial. Mesmo quando essa não ocorria, havia ainda a possibilidade de ataques por parte de vizinhos.

A grande novidade foi o surgimento de uma nova atitude que, deixando de lado um certo sentimento de culpa, até então bastante comum mesmo entre os homossexuais mais notórios, passou a reivindicar um espaço de respeitabilidade pública para a homossexualidade. Esse espaço foi encontrado pelo movimento homossexual dentro do 
contexto de contestação cultural e das tentativas de organização de certos setores da sociedade, como os negros, as mulheres e índios, em torno de demandas específicas, que fugiam do esquema classista, até então considerado essencial para questões políticas "sérias". A partir de 1978, começam a surgir grupos de indivíduos dispostos a se declararem como homossexuais em público e que, recusando a pecha de "marginais" ou "doentes", passam a reivindicar o status de "discriminados" procurando alianças políticas com outros setores em situação similar.

Existem relatos considerados apócrifos por alguns, mas importantes por serem indicadores do surgimento de novas ideias, de duas tentativas de convocação de um Congresso de Homossexuais no Rio de Janeiro em 1976 e 1977. ${ }^{1}$ Em 1976, um rapaz mandou imprimir uma série de panfletos, convocando os homossexuais cariocas a se reunirem em uma certa hora no prédio do Museu de Arte Moderna. Os panfletos foram distribuídos pessoalmente pelo seu idealizador na Cinelândia, assim como outras áreas frequentadas por homossexuais, e entregues a todos os jornais da cidade. Mas, somente os jornais mais sensacionalistas deram qualquer importância ao fato e ninguém compareceu. Segundo uma versão da história, um forte esquema policial foi armado para dispersar a reunião, o que teria sido a razão de seu fracasso.

Também na data de 1976 a primeira tentativa realizada por João Silvério Trevisan de estabelecer um grupo de discussão homossexual. Ele voltava de uma viagem que durou três anos e, no clima opressivo de então, procurava gente para discutir as ideias que desenvolvera nesse tempo. Segundo diz, buscava também pessoas para formar um grupo que lhe desse o apoio afetivo necessário para aliviar os problemas que advinham de sua solidão e de seus interesses homossexuais. No fim de 1976, Trevisan conseguiu finalmente formar um grupo de discussões, cujo número de participantes oscilava entre cinco e dez. Eram profissionais liberais, em sua maioria, incluindo professores, estudantes e um médico. Durante certo tempo, dedicaram-se ao estudo

1 Por essa informação, agradeço a João Mascarenhas. 
de um artigo sobre machismo, publicado no jornal Somos, da Frente de Libertação Homossexual da Argentina, mas, depois de algumas semanas, o grupo se dissolveu. Segundo Trevisan, aquelas pessoas, embora se sentissem marginalizadas, somente se interessavam em discutir política partidária e a maioria ainda parecia acreditar que a homossexualidade era uma "anormalidade".

No ano seguinte, em 1977, Winston Leyland, editor do jornal americano Gay Sunshine, realizou sua já mencionada visita ao Brasil à procura de material para uma antologia de contos homossexuais latino-americanos que estava organizando. Sua vinda serviu para reunir o grupo de jornalistas e intelectuais homossexuais, incluindo Trevisan, que posteriormente viriam a editar o jornal Lampião. Entre um pequeno grupo de intelectuais, artistas e boêmios do eixo Rio-São Paulo, a visita de um "líder gay" dos Estados Unidos foi considerada um evento importante e lançou-se a ideia de produzir no Brasil uma publicação séria, destinada a promover a discussão política da homossexualidade. Depois de alguns meses de discussão, foi editado o número zero do Lampião em abril de 1978.

Nesse mesmo mês, ocorreu outro evento que também foi importante para a constituição do primeiro grupo de militância política homossexual. Entre 24 e 30 de abril de 1978, a revista Versus, uma publicação alternativa, originalmente autônoma, mas, já nessa época, sob o controle da organização trotskista Convergência Socialista, promoveu uma semana de amplos debates políticos. Chamado Semana do Movimento da Convergência Socialista, este evento visava a elaboração de uma plataforma para um planejado Partido Socialista Brasileiro. ${ }^{2}$ Para tanto, organizou-se uma série de discussões sobre problemas como anistia, constituinte, liberdades sindicais, e imprensa alternativa. No dia reservado para debater a imprensa alternativa, contava-se com a presença de representantes dos vários "nanicos" existentes, como Movimento, Em tempo, etc. e também alguém representando o recém-criado, mas ainda inédito, Lampião. Alguns colaboradores da seção afro-latina da revista Versus, integrantes da Convergência Socialista

2 Lampião, n. 2, p. 9, jun. 1978. 
(CS), se encarregaram de fazer os necessários contatos com as diversas equipes de redação envolvidas. Como eles, particularmente, não achavam conveniente a presença de porta-vozes de reivindicações homossexuais, unilateralmente resolveram boicotar o Lampião, alegando que havia sido impossível entrar em contato com a sua redação.

De alguma forma, esse fato chegou ao conhecimento de pessoas que haviam, em discussões iniciais, se empenhado para que o convite fosse estendido ao jornal homossexual. Perante aquele ato de indisciplina partidária, resolveu-se pedir a um rapaz, já muito envolvido com grupos de esquerda, mas não integrante da Convergência Socialista, que redigisse uma moção de protesto, para ser lida durante os debates sobre a imprensa. Nesse dia, portanto, à certa altura do debate, ele pediu a palavra e leu a seguinte moção, sob o olhar fulminante dos responsáveis pelo boicote, que alegavam que a inclusão de reivindicações homossexuais no programado partido levaria inevitavelmente a um afastamento da classe operária:

No momento em que se discutem amplamente as questões relativas às lutas democráticas no país, não é possível esquecer as lutas das minorias discriminadas. Essas discriminações ocorrem não só no plano institucional como social, moral e sexual. Discriminado moral e socialmente, resta ao homossexual reprimir seus legítimos anseios, fazendo de uma frustração pessoal e moral a frustração de sua participação na produtividade social e coletiva, identificado com o geral da sociedade. Aqueles que, contrariando todas as regras, resolvem assumir-se publicamente, são atirados à mais aviltante situação para a própria sobrevivência: a prostituição. Outros, que conseguem sair dessa situação espúria, apenas são admitidos no rol da sociedade burguesa e capitalista como profissionais liberais do supérfluo e da futilidade: cabeleireiros, costureiros, decoradores, atores, etc.

A questão do homossexualismo masculino e feminino salta neste momento como questão fundamental a ser reconhecida como uma das lutas democráticas, que tem características próprias, mas não se afasta da luta mais ampla pela reformulação da moral sexual brasileira, seja hétero ou homossexual, por todos aqueles que acreditam na possibilidade de uma sociedade mais justa e democrática. Os homossexuais, vítimas de um sistema discriminatório, reacionário e intolerante, esperam da Convergência Socialista a acolhida de sua 
luta. Confiamos em que o socialismo que pretendemos seja um sistema equitativo, aberto e democrático, que tenha o ser humano como peça fundamental, independente de sua sexualidade, traga em seus fundamentos o necessário elemento democrático que permita a todos as mesmas possibilidades. ${ }^{3}$

Essa colocação imediatamente serviu de estopim para uma longa discussão sobre homossexualidade e política. Tão intenso foi o interesse no assunto demonstrado pelos presentes, que a discussão sobre imprensa alternativa se esvaziou e não pôde ser retomada naquele dia. Contrariamente ao que havia sido alegado, os operários presentes não se afastaram, mas parecem ter tomado parte ativa das discussões. Segundo matéria do Lampião, porém, "teve gente que se retirou dizendo que viera participar, antes de mais nada, de uma reunião de machos". 4

O último dia dessa Semana do Movimento da Convergência Socialista havia sido reservado para uma discussão geral de todos os assuntos levantados e a elaboração de um programa de ação. Advertidos do que ocorrera no dia da discussão sobre a imprensa, Trevisan e alguns amigos homossexuais compareceram à reunião, onde puderam presenciar os lances finais do episódio. A uma certa altura, foi feita uma proposta de apoio às “minorias", entre as quais se incluíam negros, índios, cegos, crianças, velhos, paraplégicos, homossexuais, mulheres e doentes mentais. Para evitar essa longa enumeração de "minorias", foi levantada outra proposta, que elas não fossem especificadas. Mas os negros presentes, entre os quais, aparentemente, se encontravam os propositores iniciais do boicote, insistiram na especificação do apoio à luta negra. Isto forçou uma solução de compromisso, levando a uma enumeração mais reduzida das "minorias" a serem apoiadas: as mulheres, os negros, os índios e os homossexuais. Mais tarde, ficou também esclarecido que os militantes que boicotaram o Lampião e, a uma certa altura, até ameaçavam de retirar a seção Afro das discussões, caso comparecessem também os homossexuais, estavam agindo por conta própria e não representavam nem a posição

\footnotetext{
3 Lampião, n. 2, p. 9, jun. 1978.

4 Lampião, n. 2, p. 9, jun. 1978.
} 
do conjunto dos militantes negros e nem da Convergência Socialista como um todo.

Esse incidente, ocorrido antes mesmo da constituição do movimento homossexual, já permitia antever uma série de características que iriam se mostrar marcantes no seu desenvolvimento posterior. Ficou patente, por exemplo, o enorme interesse despertado pelas discussões do assunto que, aqui e em ocasiões posteriores, tendia a ofuscar todos os outros temas colocados para debate. Constatou-se também que, apesar dos homossexuais sempre recearem ataques vindos de operários e suas organizações, estes, na maior parte das vezes, têm se mostrado dispostos a discutir a homossexualidade de forma cordata. Levantava-se aqui, pela primeira vez em público, a ideia de que os esforços dos homossexuais para obter um melhor posicionamento dentro da sociedade se inscreviam legitimamente na luta mais ampla por uma sociedade mais democrática e socialista. Embora ocorressem manifestações de intolerância, estas geralmente eram de natureza individual e a objeção mais comum levantada durante essas discussões era a de que a luta dos homossexuais seria secundária, devendo-se dar prioridade à luta de classes. Até então, questões de discriminação desse tipo, levantadas mais costumeiramente por negros e por mulheres, haviam tido suas soluções postergadas para depois do advento de uma esperada revolução socialista.

Outro ponto que fica evidente aqui é uma certa dificuldade no relacionamento entre militantes da causa negra e da causa homossexual. Apesar de serem bastante similares os processos de discriminação, aos quais ambos os grupos estavam sujeitos, persistia uma incompreensão. Veremos mais adiante se repetir com frequência as desavenças entre grupos muito parecidos, sendo que, quanto mais próximos estão, maior parece ser a agressividade que um volta contra o outro. Assim, embora os brancos homossexuais tenham se dado razoavelmente bem com os militantes heterossexuais do movimento negro, eram constantes as brigas destes com militantes negros homossexuais. Igual fenômeno se repetiria entre militantes dos movimentos homossexual e feminino. As feministas heterossexuais, embora se dessem bem com homens homossexuais, se desentendiam com as militantes lésbicas. 
Como já foi dito, o importante desse episódio é o fato de ele ter sido a primeira vez em que se deu uma discussão pública, explicitando os aspectos políticos da homossexualidade. Ânimos se exaltaram; Trevisan e outros homossexuais presentes decidiram formar um grupo para levar adiante aquelas reflexões. A partir do mês seguinte, foram realizadas várias reuniões semanais, frequentadas por uma média de quinze pessoas. Embora alguns participassem dessas reuniões assiduamente, outros compareciam mais esporadicamente. A composição do grupo era exclusivamente masculina, muitos dos seus integrantes eram profissionais liberais, havendo também um numeroso contingente de atores. Esses últimos, porém, logo deixaram de comparecer às reuniões, entre outros motivos, por se sentirem prejudicados profissionalmente ao assumir abertamente o rótulo de homossexuais.

Um dos principais problemas enfrentados por esse grupo era determinar o que fazer, mas já se prenunciavam importantes dificuldades que viriam posteriormente se apresentar ao movimento homossexual. Alguns preferiam enfatizar os aspectos da sociabilidade do grupo e propunham que se fizessem relatos do tipo confessional, seguindo a prática feminista, para que os participantes pudessem adquirir um melhor entendimento da homossexualidade e do papel que desempenhava em suas vidas. Enfatizavam a necessidade de se descobrir a "essência homossexual", antes de se adotar posicionamentos políticos. Contra essa posição, surgia outra, que pretendia promover uma discussão menos restrita, enfocando a sexualidade em todas as suas manifestações (homo, hétero, bi, etc.) e dando ênfase ao problema da discriminação social sofrida por homossexuais. Era invocada a necessidade de se organizar um amplo movimento de minorias e uma aliança efetiva com as feministas. Dizia-se, entre os partidários dessa posição, que, persistindo em discussões fechadas, se criava mais um gueto e promovia-se a autodiscriminação dos homossexuais. Preocupados em questionar a regulamentação social da sexualidade em todas as suas manifestações, os adeptos dessa opinião eram contrários à ideia do grupo ser integrado somente por homens e homossexuais, o que era anátema para os que defendiam a posição contrária.

Também falava-se que a insistência em reforçar estereótipos de "fechação" era contraproducente e só confirmava os preconceitos da 
sociedade. Os partidários dessa visão mais “política” eram contrários à tendência do grupo virar um simples local de encontro, paquera e apoio afetivo, alegando não terem necessidade de um grupo formalizado para suprir essas necessidades.

Apesar de suas divergências, os participantes do grupo continuaram a se reunir durante três meses, fazendo relatos de sua vida íntima, seguidos de discussões denominadas "reuniões de identificação". Ao término desse período, o grupo sofreu várias deserções e corria o risco de se desfazer em virtude de diferenças afetivas e ideológicas. Estas se traduziram em uma disputa de lideranças, na qual um dos partidários do enfoque mais "político" foi acusado de ser militante da organização Convergência Socialista e de tentar atrelar o grupo a ela.

Data dessa fase do grupo o seu primeiro aparecimento em público, com uma carta de protesto enviada ao sindicato dos jornalistas reclamando da forma sensacionalista e preconceituosa com que a imprensa costumeiramente tratava a homossexualidade. Receosos de se exporem ao grande público como homossexuais, os integrantes do grupo optaram por assinar a carta com um nome coletivo e às pressas se batizaram provisoriamente de "Núcleo de Ação pelos Direitos dos Homossexuais". Depois de denunciar o sensacionalismo do jornal Notícias Populares, citando exemplos de matérias nas quais a temática homossexual havia sido tratada de forma preconceituosa, a carta continuava:

Algumas camadas das classes médias poderiam considerar esse jornal como inofensivo, isto é, ninguém levaria a sério seu estilo jornalístico. Mas nós entendemos que a mentalidade veiculada pelo Notícias Populares é extremamente perigosa e reveladora da falta de ética profissional de quem nele escreve e de quem o financia. Com efeito, se muitos setores o desconhecem ou o tomam como literatura de humor, existe uma camada popular de relevância que o lê, o consome e acredita nele. É assim que, nessas classes populares, desenvolvem-se atitudes e preconceitos contra o conjunto dos homossexuais. Não dar a devida importância à veiculação incessante dessa ideologia preconceituosa, além de significar um desrespeito à ética profissional, é uma omissão que implica em consentimento.

Nós, que escolhemos uma sexualidade discriminada por certos grupos repressores, somos marginalizados e condenados desde há muito tempo ao silêncio. Por isso, constituímos 
um grupo social facilmente objeto deste tipo de explorações comerciais impunes, como a prática de tal jornal evidencia. Em nossos dias, a livre aceitação da própria sexualidade começa a ser encarada como um dos direitos humanos fundamentais. Também sabemos hoje que a homossexualidade não é uma doença a ser curada. A pergunta 'Por que se é homossexual' aparece tão irrelevante como a pergunta 'Por que se é heterossexual'. É num momento assim que o procedimento de Notícias Populares pode ser compreendido como uma reação de defesa não causal, ainda que talvez não premeditada. Para os interesses de certos grupos, é perigoso que camadas até afora reprimidas e/ou marginalizadas - mulheres, negros, homossexuais, índios - tomem consciência dos motivos da sua opressão. Essa espécie de pecado original a que estavam condenadas só foi criada para que 'tudo andasse bem na sociedade'. É também perigoso que nós, homossexuais, contestemos essa ideologia, onde um ser (o macho) domina o outro (a fêmea) com uma finalidade (a reprodução). Nesse sentido, com efeito, de uma sexualidade onde pretendemos que não exista um dominador e um dominado, e cuja 'finalidade' é estritamente lúdica. Sabemos que não será através de concessões parciais que esta realidade mudará. Ela mudará quando mudar o sistema todo.

Não é casual, portanto, que a ideologia exposta no Notícias Populares vise manter a imagem do homossexual-criminoso-traficante-corruptor e, como se tudo isso não bastasse, doente, e doente que não quer 'sarar'.

Nós solicitamos ao Sindicato dos Jornalistas Profissionais do Estado de São Paulo que, na sua qualidade de órgão representativo da classe, torne público nossos protestos com relação ao referido jornal para que esse tipo de desrespeito ético não se repita, nele ou em qualquer outro órgão de imprensa.

Nós continuaremos alertas quanto a futuras ocorrências desse teor que, doravante, não deixaremos passar em branco.

Cópias desta carta estão sendo enviadas a:

Associação Brasileira de Imprensa, Comissão Justiça e Paz, Ordem dos Advogados do Brasil e Sociedade Interamericana de Imprensa

Assinado:

Núcleo de Ação pelos Direitos dos Homossexuais

Esta carta foi a primeira elaboração por escrito dos princípios e ideias correntes nas discussões do grupo e vários pontos nos chamam à atenção. $\mathrm{O}$ mais interessante é a concepção feita pelo grupo 
da razão pela qual a homossexualidade seria alvo de tanta agressão. De um lado, a homossexualidade é vista como intrinsicamente igualitária, na qual, por serem do mesmo sexo, os parceiros não oprimiriam um ao outro, por outro lado é enfatizada a sua natureza lúdica. Esta apontaria para a importância de outros valores que não aqueles ligados diretamente à produção e seria a causa de sua incompreensão, tanto por parte da direita quanto da "esquerda sisuda"; ideia desenvolvida em pronunciamentos posteriores no movimento homossexual.

Mais uma vez, evidencia-se também a confusão dos integrantes do grupo a respeito da natureza da homossexualidade. Está implícita, nessa carta, uma posição de "assumir a homossexualidade" que iria ser uma característica forte do movimento. Enfatizando esta posição, a carta contém a frase: "Nós, que escolhemos uma sexualidade discriminada por certos grupos repressores [...]". Porém, este conceito de "escolha" de uma sexualidade parece contradizer uma outra expressão que segue logo abaixo, em que se fala da "livre aceitação da própria sexualidade", que é tratada como algo, quase uma imposição independente da vontade individual, que deve ser aceita.

A confusão a este respeito toca em uma dificuldade básica da militância homossexual em definir uma postura coerente sobre a homossexualidade, que fosse além da simples recusa da noção de doença ou de encarar a sociedade como repressora da sexualidade, mais do que como sua criadora. Como nesta carta, a discussão do assunto é geralmente remetida exclusivamente ao foro íntimo, não sendo considerado da conta de ninguém, muito menos de médicos ou psicólogos interessados em encontrar a etiologia da "doença". No máximo, existe a tentativa de explicar as razões para a repressão, e comumente diz-se, como na carta acima, que a livre expressão da sexualidade é uma ameaça à posição de poder de "certos grupos".

Partindo dessas premissas, pede-se a rejeição do reformismo e uma mudança total do sistema social, em uma direção pouco explicitada, embora vagamente antiautoritária. Vale apontar aqui que esse chamado não refletia um consenso entre os integrantes do grupo. Como se pode ver, pela lista de organizações a quem cópias da carta seriam remetidas, os membros do "núcleo" consideravam que participavam dos mesmos esforços das principais associações civis que 
lutavam contra a ordem ditatorial vigente e desejavam ser reconhecidos como aliados sérios, dispostos a não mais deixar "ocorrências desse teor" passar em branco.

Apesar de serem formuladas em nome do grupo, colocações desse tipo iriam, no futuro, refletir o posicionamento pessoal daqueles encarregados da redação dos documentos, mais do que um consenso grupal, aliás, inexistente. Indefinições desse tipo, sobre os objetivos últimos de suas atividades, iriam dar margem a sérios desentendimentos, levando até a fragmentação do grupo em 1980.

\section{Surge o "Lampião" e o grupo se reestrutura}

Como já foi mencionado, a partir da vinda ao Rio de Janeiro do redator da revista americana Gay Sunshine no final de 1977, um grupo de jornalistas e intelectuais brasileiros passaram a formular a criação de um jornal dedicado à discussão da questão homossexual. Este, cujo número um foi lançado em maio de 1978, recebeu o nome de Lampião. Originalmente pretendia-se que as reuniões de pauta do jornal ocorressem alternadamente em São Paulo e no Rio de Janeiro, uma vez que três membros do Conselho Editorial: João Silvério Trevisan, Darcy Penteado e Peter Fry moravam em São Paulo. Dada a atuação de Trevisan, tanto no jornal quanto no grupo, alguns integrantes deste passaram também a colaborar ocasionalmente na publicação, como foi o caso de Glauco Mattoso, que se encarregou de organizar uma seção literária. Outros se habituaram a frequentar as reuniões de pauta, quando elas eram realizadas em São Paulo, e dessa forma cimentou-se um forte sentimento de identificação entre as duas organizações.

Em final de agosto de 1978, o grupo de homossexuais de São Paulo começou a sentir uma necessidade urgente de algum tipo de reestruturação. Esta, além de permitir a entrada de novos integrantes ao grupo, também deveria procurar alguma forma de reconciliar todos os interesses contraditórios que ele abrigava, já que sua convivência se tornava cada vez mais difícil. Para tanto, foi convocada uma reunião dos integrantes do grupo e demais interessados. Foi nessa ocasião que entrei em contato direto com aquelas pessoas pela primeira vez. 
A reunião, realizada no Teatro da Praça, na rua Apa, no bairro paulistano de Santa Cecília, foi bastante tumultuada. Alguns dos presentes insistiam na importância de um trabalho mais ligado aos outros movimentos contestatórios, como o operário. Isso causou muitos protestos e a veemência com a qual tais ideias eram combatidas por parte de alguns dos fundadores do grupo parecia incompreensível para alguém como eu, não familiarizado com as discussões precedentes. Finalmente, foi proposta uma subdivisão em grupos menores que se reuniriam separadamente com objetivos e atividades diversas, de acordo com os interesses de seus integrantes.

Embora fossem projetados subgrupos de "estudos e discussões", "atuação externa”, "serviços", "identificação", "atividades artísticas" e "expressão não-verbal”, essa proposta refletia uma ambição irrealista e a nova estrutura nunca chegou a funcionar. Somente o subgrupo de "identificação" teve algum sucesso em segurar alguns dos integrantes do Núcleo de Ação pelos Direitos dos Homossexuais, que, no seu todo, sofreu um acentuado esvaziamento. Durante algumas semanas, as reuniões desses interessados remanescentes se resumiam a melancólicos encontros semanais em que, uma vez colocadas as várias experiências individuais relacionadas à sexualidade, reinava um sentimento de desnorteamento. Os integrantes desse grupo pareciam ter, como único elo, uma certa amizade entre si e as discussões facilmente fugiam dos temas de militância ou sexualidade.

Com a ideia de realizar uma pesquisa sobre o grupo, procurei participar de suas reuniões. Não me sentia muito bem vindo, pois, apesar de supostamente abertas a todos os interessados, essas reuniões eram realizadas em casas particulares, onde todos, exceto eu, pareciam ser velhos amigos. Isso me fazia sentir como um intruso. Minha experiência inicial deve ter sido bastante típica e, como outros prospectivos membros, teria rapidamente desistido se não fosse pelo meu interesse acadêmico. Apesar disso, logo comecei a me sentir bastante desmotivado a continuar persistindo, julgando que o clima de desorientação que reinava no então grupo prenunciava um final iminente para aquela tentativa de organização homossexual. As conversas pareciam se restringir a assuntos puramente pessoais, relacionados aos veteranos do grupo, e eu, como recém-chegado, sentia-me excluído. A única 
discussão concreta que parecia se dar girava em torno da escolha de um novo nome e, talvez, de um logotipo para o grupo. Atarefadíssimo com outros assuntos, logo deixei de frequentar o grupo, propondo-me a, talvez, retomá-lo depois das férias de verão, quando teria mais tempo disponível. Consequentemente, perdi dois acontecimentos de importância crucial: a adoção do nome Grupo Somos de Afirmação Homossexual e a sua primeira participação em um debate público realizado naUniversidade de São Paulo (USP), em fevereiro de 1979.

\section{O Grupo se batiza e sai em público}

Havia vários meses em que se discutia um nome mais adequado para o grupo e uma proposta, originalmente levantada por Glauco Mattoso, um dos seus integrantes, era de que se adotasse o nome "Somos". Este era o nome de uma publicação da já extinta Frente de Libertação Homossexual da Argentina. Foi julgado atrativo por ser curto, afirmativo, forte e palindrômico. Esta última qualidade do nome, de poder ser lido da esquerda para a direita e da direita para a esquerda, foi provavelmente o que captou a imaginação de Glauco, um entusiasta da poesia concreta. Além disso, fazia uma interessante brincadeira com o fato de ser o nome de um grupo de "invertidos". Este aspecto foi reforçado pelo logotipo escolhido, mas pouco usado, que era a palavra Somos, com o último "s" invertido. $\mathrm{O}$ nome anunciava, acima de tudo, o desejo de se "assumir a homossexualidade", potencializado com o complemento "de afirmação homossexual". Essa decisão final pelo nome do grupo parece ter sido tomada em dezembro de 1978, após um convite para participar de uma semana de debates na Universidade de São Paulo (USP), sobre o tema $O$ caráter dos movimentos de emancipação.

Esse evento foi realizado na Faculdade de Ciências Sociais, no começo de fevereiro de 1979 e suas discussões focaram primordialmente a luta dos grupos discriminados no Brasil: negros, mulheres, índios e homossexuais. Sua participação no debate sobre a homossexualidade foi um grande marco na história do grupo e, a partir dele, o Somos começou a ser mais amplamente conhecido. No dia 8 de fevereiro, tratou-se especificamente da questão homossexual. O debate 
durou três horas e na mesa debatedora estavam seis homossexuais declarados. Representando o Lampião estavam Darcy Penteado e João Silvério Trevisan; havia três representantes do Somos e também Roberto Piva, autodenominado "poeta homossexual-proletário", autor de vários livros de poemas nos quais a temática homossexual é constante. O plenário lotado contava com cerca de 300 pessoas, ${ }^{5}$ em sua grande parte, ligadas à política estudantil. Como ocorreu em outros debates subsequentes aos quais o Somos compareceu, o clima tornou-se altamente emocional e a mesa expositora foi ignorada durante grande parte do tempo, quando a discussão era direcionada pelo próprio plenário.

A semana de debates se caracterizou pela polêmica entre os integrantes dos vários grupos ditos "minoritários" e os representantes das posições ortodoxas das diversas organizações socialistas. Os negros do Movimento Negro Unificado criticavam a esquerda tradicional branca, dizendo que, em nome de ideologias progressistas, ela acabava acentuando a descaracterização cultural do negro, ditando-lhe regras de ação. Esse tipo de colocação levou os negros a serem acusados de divisionistas e vários militantes socialistas se retiraram do recinto. Durante o debate das mulheres, ocorreu uma desavença entre as próprias expositoras que inflamou ânimos. A representante do Movimento do Custo de Vida, a certa altura, acusou de pequeno-burguesas as exigências de autonomia para os grupos feministas que haviam sido articulados pela representante do jornal Nós mulheres. Muitos da plateia recusavam a admitir o status de luta política para a atuação das feministas e de outras "minorias", taxando-as de simples “discussão existencial”. Em resposta, as mulheres argumentavam que seus problemas extrapolavam os limites do capitalismo e reivindicavam o direito de conduzirem sua luta sem esperar o advento de uma revolução social. ${ }^{6}$

O próprio termo "minoria" foi muito contestado, por denotar uma coisa menos importante, secundária e não representativa. Lembrou-se

5 Lampião, n. 10, p. 10, mar. 1979

6 Lampião, n. 10, p. 10, mar. 1979 
de que as mulheres, obviamente, não podiam ser chamadas de "minoria", pois formavam mais de $50 \%$ da humanidade, enquanto os negros falavam da dificuldade e falta de interesse governamental em determinar com precisão seus números em relação ao resto da população. Os homossexuais, por seu lado, lembraram que, dada a sua invisibilidade, era mais difícil ainda calcular os seus números. Todos concordaram em denunciar as definições invariavelmente ditada pelos homens brancos e heterossexuais que, como donos do poder, se colocavam como "maioria", e se erigiam como os padrões da "normalidade".

Entre os homossexuais reinava um grande clima de euforia e união. Durante os debates especificamente sobre homossexualidade, havia-se constatado, com uma agradável surpresa, o quanto as posições autonomistas do Lampião e do Somos eram difundidas e encontravam respaldo. À certa altura, alguém da plateia fez o seguinte discurso:

Eu vou dizer agora o que metade deste auditório está sequiosa para ouvir. Vocês querem saber se o movimento gay é de esquerda, de direita ou de centro, não é? Pois fiquem sabendo que os homossexuais estão conscientes de que para a direita constituem um atentado à moral e à estabilidade da família, base da sociedade. Para os esquerdistas, somos um resultado da decadência burguesa. Na verdade, o objetivo do movimento gay é a busca da felicidade e por isso é claro que nós vamos lutar pelas liberdades democráticas. Mas isso sem um engajamento automático com os grupos da chamada vanguarda. ${ }^{7}$

A esse tipo de argumento, um defensor de posições esquerdistas mais ortodoxas, a certa altura, fez a seguinte declaração suscitando vaias, xingos e protestos do auditório: "Se não for para a gente caminhar juntos, então eu quero que os homossexuais vão à puta que os pariu".

Defendendo um não engajamento com organizações voltadas à política tradicional, outro rapaz falou:

Não adianta querer envolver nossa problemática em termos de política. Trata-se de um problema específico, que atinge a um determinado número de pessoas de características dife-

7 Lampião, n. 10, p. 9, mar. 1979, 
renciadas. Eu, particularmente, acho que é muito mais válido mostrar para aquele pessoal pintoso, as bonecas da zona boêmia, a sua condição de homossexual, a opressão que os atinge diretamente, do que chegar até eles com papos culturais e politizados sobre os movimentos de emancipação do proletariado. É lógico que muitos homossexuais já têm uma posição política definida, e já devem estar engajados nessa luta mais ampla. Mas acredito que, nesse momento, a ação política mais consequente é mostrar, à imensa maioria dos homossexuais, o estado de alienação em que eles estão e mostrar isso como um igual. Nunca como um intelectualzinho com o rabo cheio de cultura, mas como um ser com o mesmo tipo de problema e necessidade de libertação.

O mesmo rapaz, em diversas ocasiões, emitiu outros conceitos que também tiveram grande aceitação da plateia, como: "O problema de qualquer revolução é saber quem vai lavar a roupa depois”; e sobre a visão moralista da religião: "A Igreja também precisa acabar com esse negócio de ficar jogando água benta no cu dos homossexuais". ${ }^{8}$

Durante as exposições iniciais, um representante do Somos explicou o que o grupo havia feito durante seu quase um ano de existência; falou sobre a sua estrutura e manifestou o desejo de aglutinar mais lésbicas e homossexuais negros, pouco representados no grupo naquele momento. A ausência destes no Somos foi explicada como decorrente da maior opressão sofrida pelas mulheres e pelos negros homossexuais.

Essa semana de debates teve grande repercussão e, a partir de então, o tema "minorias discriminadas" passou a ser constante nas discussões políticas. A insistência na autonomia dos grupos "minoritários”, em relação às organizações de cunho político partidário mais tradicional, lhes dava pontos em comum com as inúmeras organizações populares que começavam a surgir nas periferias das grandes cidades, lutando contra loteamentos clandestinos, exigindo a melhora dos serviços públicos, etc. Atuando fora do espaço dos partidos políticos e dos sindicatos, essas organizações, mais do que simples movimentos contra o empobrecimento crescente, são consagradas à exigência do atendimento das novas necessidades decorrentes do

8 Lampião, n. 10, p. 9, mar. 1979,. 
processo de urbanização. Lutam também pela ampliação do acesso ao espaço político e aos benefícios do desenvolvimento econômico.

Apesar de sua composição heterogênea em termos de classes sociais, internamente, esses grupos procuram enfatizar a igualdade de seus integrantes em face de uma carência coletiva. Por isso, procuram ignorar as distinções de classe, filiação partidária, denominação religiosa, etc., que surgem em seu seio. Procuram, também, evitar diferenciações internas que a adoção de uma estrutura hierárquica poderia provocar. Para tanto, esses grupos são contrários à delegação de poderes ou de representatividade, buscando envolver todos os seus integrantes, tanto nas decisões comunitárias, quanto nas suas implementações. Esses grupos procuram também evitar a interferência de agentes de fora e se encontram em permanente estado de desconfiança a respeito do que percebem como tentativas de manipulação externa. (DURHAM, 1984)

A divulgação bastante generalizada dessas posições entre certos meios intelectuais e políticos tornava justificável, para muitos, as posições autonomistas dos grupos de "minorias discriminadas". Esses, reconhecendo os pontos estruturais que compartilhavam, resolveram, então, construir um Comitê dos Grupos Discriminados, para servir como elo de comunicação entre eles. Porém, esse comitê nunca funcionou e a proposta foi logo esquecida.

Para os homossexuais, houve um saldo mais positivo dos debates: organizou-se uma reunião cinco dias depois, no Teatro da Pontifícia Universidade Católica de São Paulo (TUCA), quando se apresentaram dois novos grupos homossexuais, além do Somos. Um era formado por estudantes da Faculdade de Filosofia, Letras e Ciências Humanas da Universidade de São Paulo (USP) que se apresentou como existente há algum tempo e dedicado a estudos teóricos sobre a homossexualidade. Convidados a se juntar ao Somos, como um grupo de estudos dentro do Somos, seus integrantes se recusaram e, depois de uma série de desavenças, formaram o embrião de um novo grupo de militância homossexual, o Grupo Eros. Alguns estudantes de Guarulhos também manifestaram o desejo de formar um grupo em sua cidade. Este, mais tarde, viria a tomar o nome de Libertos.

Um mês depois, vários grupos homossexuais paulistas se reuniram novamente na PUC sob convite do diretório estudantil. Nessa ocasião, 
debateu-se a formação de um organismo que englobasse todos os grupos, a ser denominado Núcleo de Proteção aos Direitos dos Homossexuais, mas ficou patente uma grande rivalidade entre o grupo da Faculdade de Filosofia e o Somos. Falou-se muito em liderança e perigo dos grupos se fecharem em demasia. Dois dos fundadores do Somos eram constantemente apontados como líderes, embora dissessem rejeitar tal papel. O grupo de Guarulhos se declarou ainda em processo de formação, embora seus fundadores exercessem um papel bastante ativo, e um deles, a certo momento, chegasse a ocupar o cargo de coordenador da reunião, para apressar seu andamento. Houve muita reclamação por parte de todos os presentes, que alegaram que grande parte da reunião tinha sido tomada pela discussão de assuntos já debatidos nas recentes reuniões da Universidade de São Paulo (USP) e da PUC. Um dos poucos pontos novos levantados foi a necessidade de se enviar uma carta de protesto ao jornal Em Tempo, que havia publicado uma longa lista de torturadores, qualificando alguns simplesmente como homossexuais, no melhor estilo da imprensa marrom.

Combinou-se realizar encontros periódicos de representantes dos vários grupos, mas esses encontros logo deixariam de ocorrer, dada a crescente incompatibilidade entre eles. Isso deu origem a uma série de reclamações mútuas que iriam se repetir diversas vezes nos dois anos seguintes. O Somos reclamava que só ele realizava trabalhos, tendo que "carregar os outros grupos nas costas". Enquanto isso, o Eros e o Libertos reclamavam das atitudes de liderança assumidas por alguns integrantes do Somos. Mais tarde, viriam a criticar as tendências "imperialistas" do Somos, acusando esse grupo de procurar dominar os outros ou então de desejar aparecer em público sozinho, ignorando a sua existência. A essas acusações, integrantes proeminentes do Somos respondiam que o grupo da Universidade de São Paulo (USP) era autoritário, pois vinha sempre com posições “acadêmicas" já preparadas - na época estavam empenhados em ler e discutir a versão em espanhol do livro "A revolução sexual" de Daniel Guérin. Sua postura seria demasiadamente "acadêmica", pois eles achavam necessário estudar teorias sobre a sexualidade antes de partir para a prática política. Também seriam pouco "assumidos", 
rejeitando o uso de termos como "lésbicas", "caso", "bicha”, largamente empregados no Somos. Também se acusava o grupo da Universidade de São Paulo (USP) de estar muito voltado a uma "disputa pelo poder".

Dessa reunião, participaram também alguns rapazes, autodenominado Grupo do Chá, que teriam se conhecido durante "pegações" em um cinema no centro da cidade, o Cine Paissandu, famoso na época por ser ponto de encontro de homossexuais. Eles se reuniam periodicamente, mas só para "bate-papo inconsequente". Integrantes do Somos viam estes como o oposto do grupo da Universidade de São Paulo (USP), pecando por sua frivolidade e uma total falta de espírito combativo. Por essa razão, eram ligeiramente ridicularizados durante conversas entre os integrantes do Somos, mas, enquanto a ideia do Núcleo perdurou, tentava-se sempre contatá-los e incluí-los nas atividades programadas.

Porém, depois de algum tempo, os grupos deixaram de manter contatos periódicos e os membros do Somos chegaram à conclusão de que a experiência desse Núcleo havia sido prematura e só havia servido para exacerbar antagonismos intergrupais. Mais uma vez, ficava evidente a tendência desses grupos de dirigir uma grande carga de agressividade contra outros com interesses e finalidades similares. O desprezo mostrado por alguns membros do Somos pelo Grupo do Chá refletia também a atitude dos militantes homossexuais em relação aos frequentadores do gueto. Recusando-se a reconhecer a natureza altamente heterogênea da população homossexual, concebiam a sua atuação como sendo a de defender os legítimos interesses desse setor. Frente à indiferença demonstrada pela maioria dos homossexuais em relação à sua atuação política, os militantes não hesitavam em adotar os tradicionais preconceitos anti-homossexuais, manifestados pela população em geral, taxando-os de frívolos, inconsequentes, etc. Ao mesmo tempo, não podiam afastar-se demais da "massa" homossexual, que era a fonte da legitimidade política de sua atuação. Era comum, portanto, esse ir e vir, em relação aos homossexuais não organizados, desprezados por um lado e cortejados por outro.

O mês de março de 1979 também viu a primeira aparição do nome Somos na grande imprensa. Glauco Mattoso e J. S. Trevisan, do Somos, 
juntamente com Darcy Penteado, Aguinaldo Silva e Celso Curi, foram convidados pela revista Manchete a darem depoimentos. Falou-se sobre a homossexualidade, o grupo Somos e o jornal Lampião - na época sofrendo inquérito na Polícia Federal. Também foi discutido o processo a que Celso Curi estava respondendo, por atentado à moral e aos bons costumes, em razão de sua Coluna do Meio, dirigida ao público gay e, durante dois anos, veiculada pelo jornal paulista Última Hora. Porém, a reportagem resultante dessas entrevistas foi usada pela redação da Manchete como mais uma arma na sua guerra declarada ao Irã do Khomeini. Usou-se, como gancho, a perseguição contra os homossexuais naquele país e o artigo foi encabeçado com a manchete: Homossexuais no Brasil solidários com seus colegas do Irã de Aiatolá. ${ }^{9}$

O artigo continha vários erros factuais, afirmando, por exemplo, que o grupo Somos se reunia na casa do pintor Darcy Penteado, quando, de fato, este não tinha nenhuma ligação com o grupo. Mas o que irritou profundamente os integrantes do Somos foi o uso da matéria para atacar a revolução iraniana, cujos contornos na época estavam pouco definidos, e muitos ainda a concebiam como representando um passo progressista, em relação à ditadura sanguinária do Xá. Essa e outras experiências, também infelizes, mesmo com os jornais "alternativos”, levariam o grupo a uma atitude de extrema desconfiança em relação à imprensa em geral.

\section{Novos subgrupos de identificação e atuação}

O mês de março de 1979 pode, de certo modo, ser considerado aquele em que o Somos começou realmente a funcionar como um grupo aberto à população homossexual em geral, iniciando uma fase de rápido crescimento. No final desse mês, houve uma reunião que contou com a presença da quase totalidade dos que então se consideravam participantes do Somos. Compareceram entre 25 e 30 pessoas, incluindo 10 mulheres.

9 Manchete, mar. 1979 
Originalmente, pretendia-se reunir simplesmente o subgrupo de identificação, mas o grande comparecimento refletiu duas tendências. Por um lado, havia um entusiasmo muito grande pelo grupo, mas muitos ainda não haviam compreendido a sua estrutura, com múltiplos subgrupos dedicados a diferentes interesses e funções. Para eles, qualquer reunião de um subgrupo era uma reunião do grupo como um todo, aberta a todos os interessados. Manifestava-se, assim, mais uma vez, a relutância em admitir qualquer diferenciação entre os membros do grupo e até entre os homossexuais em geral.

A grande maioria dos presentes expressou seu desejo de participar de reuniões de "identificação". Revelava-se, assim, o quanto a questão homossexual ainda estava nebulosa para os integrantes do grupo e como era generalizado o sentimento da necessidade de se entender melhor o que seria a categoria "homossexual", antes de se pretender formular qualquer outro tipo de atuação. A identidade homossexual ainda era muito indefinida e o único sentimento básico a unir os participantes dessa reunião era o de que todos seriam igualmente párias sociais em razão da sua orientação sexual.

Havia gente demais para permitir uma "sessão de identificação", em que todos pudessem dar depoimentos pessoais e discutir sua experiência individual homossexual. Com tantos participantes, ela se tornou uma improvisada reunião geral do Somos e duas decisões importantes foram tomadas. Primeiro, resolveu-se abrir uma caixa postal do grupo e como, para isso, acreditava-se ser necessário formar uma sociedade civil, foi feito um sorteio para decidir em nome de quem ficariam os cargos oficiais, embora, de fato, puramente fictícios, de tal sociedade. Tirou-se a sorte, em minha presença, de uma forma totalmente honesta, mas, coincidentemente, os cargos principais foram para os dois mais destacados integrantes fundadores do grupo, um dos quais era constantemente acusado de tentar impor sua liderança sobre os outros.

A outra decisão foi sobre o subgrupo de identificação. Esse, julgado demasiado grande, foi subdividido em três. Cada um congregava entre oito e dez membros, ficando estabelecido que não poderiam ultrapassar um limite de doze integrantes. Uma vez ultrapassado esse número, o subgrupo deveria subdividir-se novamente, a fim de manter 
sempre um tamanho que permitisse a participação efetiva de todos os seus integrantes. Tomou-se cuidado em distribuir as mulheres entre os três subgrupos. Alegava-se que, dessa forma, embora ficassem sempre em situação minoritária, suas presenças enriqueceriam as reuniões de identificação, permitindo a discussão da problemática homossexual a partir do ponto de vista dos dois sexos. Embora esse arranjo viesse a ser combatido mais tarde pelas mulheres, nessa ocasião, aquelas presentes à reunião deram seu total apoio, em consonância com o espírito homogeneizador então prevalecente dentro do Somos.

Como ocorria normalmente em grande parte das reuniões, exceto durante os períodos denominados de "crise", houve muito empenho em que as decisões fossem tomadas por consenso. Considerava-se este método como sendo mais democrático do que aquele baseado em maioria de votos. Argumentava-se que isso seria necessário, para evitar que se instaurasse uma nova "ditadura da maioria" dentro do grupo, cujo corolário seria o surgimento de uma nova "minoria oprimida”. Essa preocupação foi inicialmente verbalizada por poucas pessoas, em sua maioria veteranos do grupo. Muitos dos novos membros achavam estranha a ideia da decisão por consenso, estando acostumados a associar o processo democrático com a instituição do voto e da delegação de representação política. Em várias ocasiões, foram necessárias explicações para a relutância em eleger indivíduos para cargos fixos. Nessas discussões, os proponentes do princípio do consenso invocavam, como exemplos negativos, o Movimento Estudantil e os partidos políticos, em que uma "disputa pelo poder" fazia com que grupos pouco representativos conseguissem impor sua autoridade sobre a massa, através de manobras e conchavos.

Enquanto o grupo permanecia pequeno e pouco diferenciado, em termos das ideias que discutia, o processo de decisão por consenso pareceu funcionar, embora algumas pessoas conseguissem impor suas opiniões, valendo-se de um carisma pessoal e de uma habilidade retórica que levavam ao silêncio os adeptos de ideias diferentes. Mais tarde, como veremos adiante, com o acirramento de divergências políticas, a exigência de consenso para decisões passou a ser usada oportunisticamente, como tática, por aqueles que desejavam vetar certas propostas que ameaçavam mudar o rumo do grupo. Nessas 
ocasiões, questionou-se muito a exigência de que todas as decisões fossem aprovadas por consenso e repetia-se muito o trocadilho que dizia que as decisões eram tomadas por cansaço. De fato, com o agravamento das divergências internas e o crescimento do grupo, as reuniões tornaram-se longas, cansativas e, muitas vezes, frustrantes, dada a impossibilidade de se lançar mão do método de votação para se chegar a decisões mais rápidas. Nesse contexto, ficava evidente a natureza espúria de qualquer unanimidade conseguida.

Durante essa reunião, falou-se novamente na formação de um subgrupo de atuação, mas não se conseguiu um consenso sobre a questão da autonomia ou de sua subordinação aos outros subgrupos. A importância dessa discussão logo se tornou evidente, pois, já em sua primeira reunião, o subgrupo de atuação começou a mostrar uma tendência a tomar para si a direção informal do Somos como um todo. Discutiu-se sobre a permanência ou não do grupo no Núcleo de Proteção dos Direitos dos Homossexuais e elaborou-se uma pauta, a ser obedecida pelo grupo, como um todo, em sua próxima reunião geral.

Somente sete pessoas participaram dessa primeira reunião de "atuação", evidenciando-se mecanismos informais para a seleção de seus integrantes, através de uma divulgação boca a boca, limitada àqueles mais próximos das lideranças. O coordenador provisório, escolhido pelo subgrupo, foi um dos integrantes fundadores do Somos. Começava, assim, o uso desse subgrupo como mecanismo de controle dos veteranos ou "velhos" sobre o Somos.

Na reunião geral, a primazia do subgrupo de atuação ficou confirmada pela maneira como foi fielmente seguida a pauta que ele havia elaborado. Durante esse encontro, as atribuições daquele subgrupo foram definidas como "a organização das atividades do Somos e suas relações com os grupos de fora”.

O problema da escolha de um coordenador para a "atuação" foi discutido por todos, chegando-se à proposta de uma coordenação rotativa. Esse expediente, concebido como a única maneira de preservar a democracia e evitar a cristalização de lideranças, viria a ser adotado mais tarde, em princípio, por todos os subgrupos, embora nunca funcionasse na prática. Esse fracasso deveu-se a vários fatores, mas o principal foi a já conhecida heterogeneidade do grupo. Ao 
contrário do pressuposto pelo método de coordenação rotativa, seus membros se diferenciavam muito em relação à sua disponibilidade de tempo para assistir às reuniões, ao grau de interesse pelas atividades do grupo, ao prestígio junto aos demais. Como eram poucos os que tinham a disponibilidade e o interesse para assumir uma coordenadoria, tornava-se inevitável o surgimento de uma elite que viria a procurar se perpetuar nas posições de direção.

As reuniões do subgrupo de atuação eram, em tese, abertas a todos os integrantes do Somos que quisessem assisti-las, mas uma série de fatores inibia muitos de participarem. O círculo vicioso, criado pelas lideranças desse subgrupo, talvez fosse o fator mais importante que fazia com que os integrantes novos acreditassem que não lhes competia ir às reuniões da "cúpula". Outro problema era a falta de um espaço neutro, no qual o grupo pudesse se congregar. As reuniões eram sempre feitas nas poucas residências disponíveis, o que levava àqueles que não simpatizassem muito com os donos dos locais cedidos a se sentirem pouco à vontade. Como veremos adiante, os problemas causados pela posição de liderança desse subgrupo iriam agravar-se até se tornarem críticos com o surgimento de um grupo informal de oposição, que causaria, por fim, o fracionamento da organização. 


\section{O "casamento" com o grupo}

Estudiosos dos movimentos sociais costumam enfatizar a importância dos seus aspectos expressivos e o fato de incorporarem valores que questionam o sentido básico da vida, enfatizando a comunidade, a amizade e a sociabilidade. Introduzem as dimensões afetivas da existência na discussão sobre as necessidades humanas. Viola e Mainwaring (1979, p. 165) mostram como esses movimentos incorporam noções convencionais, tanto de natureza liberal individualista quanto marxista materialista, superando essas divisões através da inclusão das dimensões afetivas da vida. Localizando o seu foco de interesse maior justamente na questão dos relacionamentos interpessoais e sexuais afetivos, os movimentos feminista e homossexual foram os que mais enfatizaram esses aspectos.

Paralelamente à consolidação do Somos, ocorria o desenvolvimento de profundos laços afetivos entre seus integrantes. Após as reuniões, eles, eventualmente, saíam juntos para jantar, tomar café ou cerveja na região do gueto homossexual, quando continuavam as discussões sobre o grupo. Essas noitadas serviam também de introdução ao gueto, para muitos que não o haviam frequentado anteriormente, além de tornarem o grupo conhecido entre homossexuais que não participavam das suas atividades. Os locais de encontro preferidos eram a lanchonete "17", o restaurante "O gato que ri", ambos no 
largo do Arouche, e o “Ferro's Bar”, tradicional ponto de reunião das lésbicas, na Rua Martinho Prado.

Quando houve uma sugestão de que se aproveitasse o feriado de 19 de maio de 1979 para realizar uma excursão de quatro dias à Praia Grande, a proposta foi recebida com entusiasmo. Naquele fim de semana prolongado, dezoito pessoas se hospedaram em um pequeno apartamento de dois quartos pertencentes à família de um dos integrantes do Somos. Apesar de nenhum dos fundadores do grupo ter comparecido, havia muita consciência de que esta era uma excursão do Somos e esse foi um tema constante de conversas e discussões. Reiterou-se o quanto todos estavam se dando bem e como normalmente seria difícil a convivência prolongada de tantos homossexuais, em condições tão exíguas. Notou-se uma ausência, considerada surpreendente, de "estrelismo" e um ótimo entrosamento entre pessoas fundamentalmente muito diferentes. De fato, conviveram com um mínimo de atrito, cinco mulheres e treze homens, alguns com mais de trinta anos e muitos com menos de dezenove. Vinham de vários estratos sociais, embora a maioria fosse orientada para uma cultura estudantil.

Vale também ressaltar que, ao contrário dos anos seguintes, não se cogitou em participar das manifestações operárias de 19 de maio, que nesse ano já começavam a capturar a imaginação da juventude universitária.

Deve-se registrar também que a proximidade física em que os participantes da excursão se encontravam - muitas vezes duas pessoas tinham que compartilhar da mesma cama de solteiro -, deu ensejo a uma grande atividade sexual. Esta ocorria geralmente baseada na amizade na compreensão e no sentimento grupal. Não surgia um sentimento de posse decorrente das relações sexuais, mantidas, concebidas como grandes brincadeiras. Muitos chegaram a ter várias relações por dia e, no final do feriado, alguns diziam ter "transado" com quase todos os presentes do seu próprio sexo. A certa altura, chegou mesmo a ocorrer uma "suruba" (orgia), em que cinco ou mais homens fizeram sexo grupal. Apesar dessa intensa atividade sexual, não ocorreu nenhum problema sério de ciúmes ou outro desentendimento amoroso. A partir dessa data, alguns começaram a se dizer "casados com 
o grupo". Como se vê, essa expressão, que refletia um sentimento de amizade e união entre os integrantes, tinha também um sentimento mais literal e algumas pessoas até passaram a restringir sua atividade sexual aos integrantes do Somos.

No fim de semana que se seguiu ao passeio, houve uma das reuniões gerais mais bem sucedidas do Somos. Compareceram quarenta e sete pessoas, incluindo dezesseis mulheres e oito outras pessoas novas no grupo. Caracteristicamente, a longuíssima pauta havia sido elaborada durante a reunião do subgrupo de atuação e depois completada por um dos fundadores do Somos. Dada a sua extensão, a reunião se prolongou das 15 horas e 45 minutos até às 22 horas e, durante os debates, foram levantados vários tópicos prenunciadores das grandes discussões, que iriam envolver o Somos. Entre estes se encontravam: a necessidade de uma sede, a possibilidade de se fazer uma reunião com homossexuais de outros estados, o reconhecimento da especificidade da problemática das lésbicas e da dupla opressão destas, enquanto mulheres e homossexuais, críticas à imprensa, tanto a estabelecida quanto a alternativa, o relacionamento entre Somos e Lampião, a necessidade de recrutar novos integrantes, a admissão ou não de heterossexuais e de menores, assim como o apoio do grupo aos operários em greve.

A discussão sobre esse último tema serviu, mais uma vez, para revelar a ausência, no Somos, de uma posição elaborada a respeito da política geral e como os ideais autonomistas contribuíam para isso. Foi dito que o grupo não deveria se atrelar ao movimento operário "só para dizer que também fazemos política”. Argumentando a necessidade do assunto ser amplamente discutido - o que poucos consideravam prioritário, preferindo discutir temas mais diretamente relacionados à homossexualidade -, dizia-se que qualquer moção apresentada refletiria somente o ponto de vista de uma minoria, sem legitimidade para representar o grupo. A solução encontrada foi elaborar uma nota de solidariedade, como grupo oprimido, e a recomendação de que o assunto fosse discutido dentro dos subgrupos. Durante essas discussões, Charlie, um rapaz recém-chegado dos EUA, mas que, em estadas anteriores no Brasil, participou das tentativas do Trevisan de formar um grupo homossexual, defendeu a necessidade de se levar 
em conta as organizações e as lutas do operariado declarando ser também filiado à Convergência Socialista.

A reunião terminou com uma prolongada polêmica sobre o meu pedido de autorização para usar o grupo, como tema para minha tese de pós-graduação em Antropologia. Várias objeções foram levantadas, como a questão de segurança, em relação à repressão policial e o receio de eu vir a dar uma interpretação demasiadamente pessoal e parcial do coletivo. Finalmente, o pedido foi aprovado por unanimidade, com a condição de que o grupo tivesse participação ativa na elaboração da tese.

Notei, com interesse, que o encaminhamento não seguia os padrões normalmente adotados em reuniões político partidárias ou do movimento estudantil. Isso, em parte, se deveu à falta de hábito de grande número dos presentes a participar de tais eventos, mas também a uma rejeição do que era visto como um formalismo desnecessário e castrador. Adotava-se, frequentemente, um tom emocional e, em vez de digressões abstratas ou teóricas, as intervenções, muitas vezes, consistiam em relatos de experiências ou sentimentos pessoais, em um estado pouco elaborado. Não havia ordem de inscrições para aqueles que desejassem falar, mas, no geral, prevalecia uma disciplina auto imposta pelos participantes para evitar que alguns falassem demais, roubando a possibilidade de outros se expressarem. Porém, aqueles que tinham mais experiência de oratória conseguiram predominar e muitos dos mais inexperientes simplesmente não tiveram coragem de tomar a palavra. Originalmente, pretendia-se que a coordenação da reunião ficasse a cargo dos vários coordenadores dos subgrupos, mas isso não funcionou e um deles assumiu a tarefa sozinho, embora procurasse fazê-lo da forma mais democrática possível.

No final da reunião, fez-se uma festa no mesmo local. Porém, prenunciando futuras tendências separatistas, algumas das mulheres presentes anunciaram a realização de uma outra festa, à mesma hora e em local próximo. Organizada para comemorar a criação de um subgrupo lésbico dentro do Somos, a festa era fechada aos homens, provocando protestos de vários membros, de ambos os sexos. Nem todas as mulheres presentes aderiram à ideia, ficando evidente uma divisão entre elas, pois a celebração planejada para ambos os sexos 
contava com uma lésbica entre seus organizadores. Esta, porém, tinha posições mais gerais de oposição à formação de um subgrupo integrado exclusivamente por mulheres. Finalmente, algumas optaram por uma solução de compromisso, participando das duas festas. A festa, na qual era impedida a entrada de homens, não teve uma frequência muito grande e, a certa altura, foi perturbada por uma briga física entre duas participantes, motivada por razões de ciúmes amorosos.

Já nesta fase, podemos detectar as duas importantes tendências antagônicas que iriam dificultar o funcionamento do Somos durante grande parte de sua existência. Por um lado, havia o igualitarismo radical, que preconizava práticas comunitaristas e negava a relevância de qualquer heterogeneidade a ser encontrada dentro do Somos ou até na população homossexual como um todo. De acordo com essa visão, todos seriam igualados por uma mesma discriminação social, dirigida contra todos os homossexuais, fossem eles homens ou mulheres, ricos ou pobres. Nisso, o movimento feminista serviu como modelo, com sua ênfase na identidade da opressão sofrida pela mulher, fosse ela uma esposa de banqueiro ou uma favelada.

Por outro lado, surgiam as inevitáveis pressões, devidas à grande heterogeneidade a ser encontrada na prática entre os homossexuais. Embora fatores diferenciadores, como status sócio econômico, idade, raça, "beleza", existissem entre os integrantes do grupo e fossem comentados, o único que a ser reconhecido, como importante e legítimo, foi a diferença de sexos. Homossexuais, masculinos e femininos, têm se mantido bastante separados. Embora, no gueto, muitos lugares de encontro sejam frequentados por indivíduos de ambos os sexos, em alguns, impera uma política declaradamente discriminatória contra homens ou mulheres. Além disso, é também comum entre homossexuais a expressão de sentimentos negativos a respeito do sexo oposto. Além desses aspectos, que poderíamos chamar de "tradicionais" entre os homossexuais frequentadores do gueto, existia uma justificativa "mais respeitável" para aqueles com motivações conscientemente políticas. Era a posição separatista e autonomista adotada por mulheres do movimento feminista, em relação aos partidos e outros agrupamentos políticos que incorporam membros de ambos os sexos. Nessa época, começava a se divulgar amplamente 
as argumentações, segundo as quais seria impossível para as mulheres tomarem consciência de suas necessidades específicas dentro de grupos mistos. Isso seria devido à irresistível tendência masculina de tratar, como gerais, as necessidades dos homens que, por conta de uma educação diferenciada, as mulheres teriam muita dificuldade em contestar. Essa mesma argumentação separatista, expressa pelas feministas, era também o suporte ideológico para a proposta de se formar grupos exclusivamente homossexuais. Era, portanto, difícil de refutar dentro do Somos.

Em contraponto à homogeneidade com que se procurava dotar o Somos, desenvolvia-se a suspeita generalizada a respeito de todos os homossexuais que não participassem dele e dos heterossexuais em geral. Assim, tanto a imprensa, exceto inicialmente o Lampião, quanto à polícia, os partidos políticos e até a universidade eram concebidos como inimigos em potencial. Enquanto se manteve relativamente pequeno, o grupo dispunha de mecanismos informais que controlavam as tendências diferenciadoras, levando os inconformados ou destoantes a simplesmente abandoná-lo. Quando, porém, o grupo começou a crescer, essas tendências se tornaram mais difíceis de ignorar, apesar de se lançar mão de vários recursos homogeneizadores.

O principal método empregado para manter a unidade do grupo foi a tentativa de promover o que o antropólogo Victor Turner chama de comunitas. Este foi um fenômeno que ele detectou, inicialmente, ao estudar sociedades sem escrita e em certos movimentos, como os dos primeiros franciscanos ou dos Viasnavas de Bengala nos séculos XV e XVI, mas que posteriormente iria também encontrar em todas as sociedades, até as mais complexas. Tornou-se, então, patente para ele que os modelos que se constroem em termos de status, papéis e cargos, embora muito úteis, não esgotavam as modalidades das relações sociais. Além do "estrutural", existiria o comunitas, concebido como um relacionamento entre indivíduos históricos, concretos e idiossincráticos, que não se segmentam em papéis ou status, mas se confrontam de uma maneira direta, imediata e total. Este tipo de relacionamento ocorre em certas épocas, quando os ciclos de desenvolvimento social e individual são marcados por instantes, mais ou menos prolongados, de liminaridade, ritualmente protegida e estimulada. 
Nas sociedades complexas, a vida social também seria marcada por numerosos instantes de comunitas espontâneo, embora, neste caso, geralmente goze de estímulos e proteções. Este tipo de relacionamento parece se desenvolver melhor em situações espontaneamente liminares, fases entre estados em que a representação de papéis sócio estruturais é dominante e, especialmente, entre pessoas do mesmo status. Nestas horas, surge um modelo de sociedade com um comunitas homogêneo e desestruturado, cujas fronteiras idealmente deveriam coincidir com as da espécie humana. (TURNER, 1974)

Turner mostra como, através da história, muito se disse e se escreveu, a respeito da melhor forma dos homens conviverem em harmonia e fraternidade. Geralmente, é feita uma ligação entre liminaridade, inferioridade estrutural, status baixo e exclusão da estrutura, por um lado, e, por outro, valores humanos universais, tais como: paz e harmonia entre os homens, fertilidade, saúde do corpo e do espírito, justiça universal, fraternidade e a igualdade, perante Deus, a lei ou a força vital, entre os homens e mulheres, jovens e velhos.

A partir de uma série de experiências muito marcantes desse tipo de "fraternidade", como a ocorrida durante a excursão à Praia Grande, e que, talvez, Turner chamasse de "comunitas existencial ou espontâneo", os integrantes do Somos procuraram idealizar um sistema social mais duradouro, que o preservasse - um comunitas normativo, nos termos de Turner. Para tanto, pregava-se uma união entre a militância e o prazer, num grupo sem hierarquia ou estrutura fixa, no qual a atuação política se baseasse no reconhecimento do valor único da individualidade de cada um de seus integrantes.

Os militantes homossexuais preenchiam os pré-requisitos apontados por Turner, para a erupção do comunitas, de estarem à margem, nos interstícios ou nos degraus mais baixos da estrutura social. Grande parte deles era proveniente de uma classe média baixa, e havia a tendência a se recrutar novos militantes entre camadas da população cada vez mais baixas, em termos sócio econômicos. O grupo tinha, em geral, uma imagem de si mesmo como pobre, em termos monetários, $\mathrm{e}$ o custo de qualquer evento programado sempre tinha que ser mantido baixo, para possibilitar a participação de todos os seus integrantes. Durante quase toda a época de que se trata aqui, o Somos não tinha 
local fixo para reuniões, dependendo de ajuda de terceiros para encontrar espaço. Isso também ajudava a manter frouxa a sua estrutura.

Além da pobreza e da marginalidade dos militantes, outro fator que promovia o comunitas era a criação de um inimigo externo. Turner faz a seguinte observação, a respeito da importância, para a constituição do comunitas, da percepção de uma ameaça:

Frequentemente vemos que o conceito de ameaça ou perigo para o grupo... está presente de forma importante. E este perigo é um dos principais ingredientes na produção do comunitas existencial, tal como a possibilidade de um "bad trip" no comunitas dos narcóticos em uma cidade moderna... Também encontramos mitos e suas representações ritualísticas em estado de liminaridade que relatam catástrofes e crises divinas... situando a crise no passado recente ou no futuro iminente. (TURNER, 1974, p. 142, grifo do autor)

Essa ideia pode nos ajudar a entender melhor o que, às vezes, parecia ser uma busca quase proposital por novos inimigos e ameaças externas. Nesse ponto, os inimigos mais eficazes seriam os mais próximos, ou seja, outros grupos homossexuais como o Eros ou, mais tarde, a Fração Gay da Convergência Socialista. Essa seria uma razão para a diferença entre o clima das reuniões do Somos e aquelas do Núcleo de Proteção dos Direitos dos Homossexuais, em que vários grupos presentes passavam grande parte do tempo se hostilizando.

\section{Os subgrupos de identificação}

Durante o ano de 1979, e no início do seguinte, o aspecto do Somos que atraía o interesse da maior parte de seus integrantes era as reuniões dos subgrupos de identificação. Sem seguir nenhum parâmetro rígido, essas reuniões consistiam, basicamente, em relatos autobiográficos, em que todos os participantes tinham a oportunidade de revelar suas concepções a respeito da sexualidade em geral, e da homossexualidade em particular. Para embasar as suas ideias, costumavam relatar episódios de suas vidas, dando ênfase especial à maneira como tinham sido afetados pela homossexualidade. 
Esses relatos possuíam uma forte carga emotiva, que levava à rápida criação de vínculos afetivos entre os membros de cada subgrupo. Ao lado da motivação política, uma das razões mais comuns que motivavam indivíduos a participarem do Somos era a necessidade de estabelecer contato com outros, em igual situação de marginalização, sexual e social. Geralmente, encontravam no Somos, pela primeira vez, a possibilidade de discutirem de maneira não culposa a sua homossexualidade, que, nesse contexto, poderia até tornar-se motivo de orgulho. Em sua grande maioria, os participantes dessas reuniões sentiam que, em pouco tempo, suas vidas mudavam, sendo comum ocorrer alterações radicais, em seus círculos de amigos e até em suas vivências profissionais ou educacionais. Velhos amigos eram relegados, surgindo uma preferência marcada pela companhia dos outros participantes do grupo. Os antigos interesses eram igualmente abandonados em favor da frequência assídua às reuniões, quase diárias, dos vários subgrupos do Somos. Tão grande era a dedicação às atividades do grupo que, durante o seu auge (1979 e 1980), vários indivíduos deixaram cursos e empregos para poder lhes devotar uma atenção integral. Era, o já mencionado "casamento com o grupo", ou o enaltecimento do comunitas.

A contrapartida do estabelecimento desse círculo afetivo era, porém, um certo sentimento de exclusão por parte dos recém-ingressos. Era notável que todos os membros mais antigos do Somos usavam como saudação um rápido beijo (selinho) na boca. Os novatos, porém, eram excluídos dessa manifestação de intimidade, embora não lhes fosse exigida uma participação muito prolongada para a admissão nesse círculo. De toda forma, essa prática servia para marcar aqueles que eram considerados como efetivos participantes do Somos e aqueles que eram "de fora". Na falta de qualquer outra formalidade de demarcação de fronteira do grupo, tais como a elaboração de uma lista de membros, o pagamento de mensalidades, etc., esse hábito informal, e raramente discutido abertamente, era o único sinal de reconhecimento de participação no Somos. Em certas ocasiões, quando o contato entre os vários grupos de militância se tornou mais rotineiro, essa forma de saudação se estendeu a todos os homossexuais organizados. 
Além do seu aspecto social afetivo, as reuniões de identificação eram importantes para a articulação de um novo tipo de discurso político homossexual, até então, completamente inexistente no Brasil. A própria questão da identidade homossexual era extremamente confusa e não era muito claro, nem para os militantes, quem seriam esses homossexuais, cujos direitos pretendiam defender.

Para lidar com esse desconhecimento, várias vezes surgiram propostas de se realizar um levantamento da população homossexual da cidade através da distribuição de questionários no gueto. Nenhuma dessas pesquisas foi levada a uma conclusão, devido à magnitude da tarefa e à falta de experiência e de recursos dos que se propunham a executá-la. Outros grupos de militância homossexual também se propuseram a fazer levantamentos desse tipo, buscando assim uma orientação para a sua atuação, como uma de suas primeiras atividades.

O aspecto confessional do chamado "processo de identificação", nos remete inevitavelmente a sugestões de Foucault, para quem a sociedade ocidental, pós século 18, elegeu, como fonte de sua verdade, a "questão" do sexo - nos dois sentidos: de interrogatório e de problematização; de exigência de confissão e de integração a um campo de racionalização. (FOUCAULT, 1979, p. 68)

Seguindo essa tendência, e, de certa forma, adotando como modelo uma prática já difundida nos "grupos de reflexão" do movimento feminista, o Somos, em sua busca pela politização da questão homossexual, entendia que, para isso, seria necessária a politização do cotidiano, do afetivo e do privado. Enfatizavam-se, então, aqueles aspectos da experiência dos indivíduos escamoteados na priorização da chamada "luta geral", costumeira dentro das organizações políticas tradicionais. Nas atividades do Somos, em geral, e, especialmente, durante as reuniões de identificação, incentivava-se, por outro lado, a tematização prioritária das questões mais pessoais.

A antropóloga Heloísa Pontes também estudou a ocorrência desse processo no grupo feminista SOS Mulher. Lá, como no Somos, esse tipo de reflexão surge como momento privilegiado de libertação, em contraposição ao silêncio, que é tido como interdição e, portanto, como resultado de um poder repressivo, patriarcal, etc. Através do relato autobiográfico, surgiria uma "fala nova" 
revelando tudo aquilo que, antes, se encontrava oculto ou suprimido. (PONTES, 1986)

Porém, na crença de que cada homossexual, ao revelar seus sentimentos mais profundos, possa reconhecer-se na "verdade" dos outros, existe a tendência, altamente homogeneizadora, de se procurar uma identidade compartilhada por todos. Em muitos casos, esse processo chegava a ser bastante eficaz, provavelmente devido ao clima extremamente emocional das reuniões. As transformações na personalidade e nos valores de muitos dos que, participantes das reuniões de identificação, chegavam a lembrar processos de conversão religiosa ou de "lavagem cerebral". Conscientes do poder normatizador desse processo, muitos militantes do Somos chegaram a concebe-lo como solução infalível para as crises que periodicamente assolavam o grupo, embora outros o encarassem com grandes reservas.

Ao contrário do que muitos achavam, creio que essas reuniões não serviam para resgatar uma fala ou cultura homossexual longamente reprimida. Como estou querendo demonstrar, mais do que sendo descoberta, uma identidade homossexual estava sendo construída. Mas, nisso, as reuniões de identificação certamente foram muito eficazes e novos valores eram criados, previamente desconhecidos mesmo entre os frequentadores do gueto. De uma forma muito real, aprendia-se a ser homossexual, ou melhor, militante homossexual. Embora muitas das ideias correntes no gueto fossem aproveitadas, grande número delas passava por uma reciclagem, sofrendo consideráveis transformações.

Porém, como já se comentou mais acima, tal era a diversidade da população homossexual em geral, que, mesmo dentro do contexto mais restrito do Somos, era inevitável o surgimento de uma certa diferenciação baseada em experiência de vida, nível sócio educacional, convicções políticas, idade, raça, charme pessoal, etc. Surgiam assim, por exemplo, lideranças informais, por parte daqueles mais experientes, com maior disponibilidade de tempo ou com ligações privilegiadas de amizade com outros "líderes". Os vários subgrupos de identificação também tendiam a assumir características próprias e seu grau de ligação com o resto do Somos era dependente da atuação de seu coordenador, que deveria servir como elo de comunicação. Alguns procuravam manter o subgrupo disciplinado e fielmente 
obediente às normas decididas durante as reuniões gerais ou, mais tarde, pela comissão de coordenadores dos subgrupos. Outros, mais "autonomistas", procuravam seguir um ritmo especificamente próprio ao seu subgrupo, contribuindo para o afrouxamento das suas ligações com a totalidade do Somos.

Com o correr do tempo, essa atitude tornou-se bastante comum e esses subgrupos tornaram-se tão dispersos que era difícil contabilizar o número dos que estariam realmente em funcionamento em um dado instante. A minha estimativa é de que, durante 1979 e começo de 1980, devem ter funcionado regularmente aproximadamente 30 subgrupos de identificação, mas, devido ao fato de alguns funcionarem até seis meses ou mais, enquanto outros se dispersavam após algumas poucas reuniões, é muito difícil ser preciso neste ponto.

O recrutamento para esses grupos se dava de várias formas. Originalmente, a principal fonte de novos membros eram as redes de amizades dos integrantes do grupo. Durante o ano de 1979, havia um grande entusiasmo no meio homossexual, em geral, pela ideia de um movimento de reivindicações que também servisse como local de encontro de novos amigos. O Lampião, durante esse tempo, também dava ampla cobertura às atividades do Somos e divulgava o número de sua caixa postal. Mais tarde, outros jornais da imprensa alternativa também começaram a discutir as posições do grupo, elogiando a sua atuação no gueto homossexual. Ser militante do Somos conferia um certo prestígio.

\section{O ideário do grupo Somos}

Inicialmente, para se ingressar no Somos bastava contatar um membro do grupo e ir com ele a uma reunião. Depois de um certo tempo, porém, os subgrupos de identificação começaram a se ressentir do permanente fluxo de recém-ingressos que atrasavam o prosseguimento dos seus trabalhos, além de dificultar a criação do espírito grupal tão almejado. Resolveu-se, então, fechar esses subgrupos de identificação, organizando-se reuniões periódicas de um grupo de recepção. Nessas ocasiões, convidava-se os interessados para um encontro com alguns militantes veteranos, que explicavam 
o funcionamento do grupo e tentavam delinear algumas das ideias correntes em suas discussões.

A visão que se preparava para os candidatos a ingresso era a de que existiria uma ampla gama de ideias e posições dentro do grupo, com cada um dos integrantes zelando pelo seu direito a ter uma opinião própria. Apresentava-se, então, uma carta de princípios, elaborada em junho de 1979 por um dos fundadores do Somos. Nem todos concordavam com as ideias lá expostas, mas, durante algum tempo, esse era um dos únicos documentos elaborados pelo grupo e era usado na falta de alternativa melhor. Mais esclarecedoras sobre o seu ideário, eram as várias exposições feitas pelos militantes veteranos. De qualquer modo, aqueles que passavam a frequentar as reuniões do Somos, logo se familiarizavam com suas posições básicas.

Eram três, os pontos, sobre os quais parecia existir uma unanimidade, entre os frequentadores mais assíduos do Somos:

1 O grupo deveria ser exclusivamente formado por homossexuais;

2 As palavras "bicha" e "lésbica" deveriam ser esvaziadas de sua carga pejorativa para, desta forma, se tornar inofensiva, uma das grandes armas usadas pela sociedade machista para oprimir aqueles que se desviam de suas normas sexuais;

3 O autoritarismo devia ser combatido em todas as suas manifestações fora ou dentro do grupo.

A partir dessas formulações básicas, quase consensuais, uma série de elaborações eram feitas, contando com maior ou menor endosso, formando o arcabouço para os debates mais teóricos que ocorriam.

Durante a fase do grupo mais estudada neste trabalho, a complexidade inerente à questão da identidade homossexual ainda não havia sido plenamente percebida pelos militantes, que tendiam a conceber a humanidade como dividida em duas categorias sexuais estanques: os homossexuais e os heterossexuais. Dizia-se, então, que a natureza exclusivamente homossexual da filiação ao grupo Somos refletia a ideia de que os setores "minoritários", como os homossexuais, as mulheres, os negros, os índios, etc., tinham reivindicações específicas, que só podiam ser levadas adiante por membros das ditas minorias. Isto porque, de um lado se achava que só os realmente interessados 
seriam capazes de assegurar a importância devida às suas reivindicações e, por outro, porque haveria a necessidade de se criar uma "consciência homossexual". Até então, os homossexuais teriam tido a palavra cassada e todos os valores propagados pela sociedade teriam a heterossexualidade e até o machismo, como a norma.

Somente fechando-se entre seus iguais, discutindo sua situação e lutando para melhorá-la é que se chegaria a criar uma consciência homossexual. Não seria necessário ouvir a posição de heterossexuais, que poderia ser encontrada por toda parte, constituindo a norma ser posta em questão.

De vez em quando, essa posição era contestada por pessoas que diziam achar necessário "educar" os heterossexuais, deixando-os conviverem com os homossexuais, ou, então, por aqueles que argumentavam que certos indivíduos heterossexuais simpatizantes poderiam vir a ajudar o grupo.

Invariavelmente, essas opiniões eram refutadas pela grande maioria dos integrantes e até os seus proponentes, quase sempre pessoas "novatas", mudavam de ideia com o passar do tempo. Sempre que abordada, essa discussão provocava reações muito emotivas, indicando que, possivelmente, o que estava em jogo não era somente algumas ideias, mas a própria natureza do grupo como um dos poucos lugares onde o fato de ser homossexual não era um fator de diferenciação ou inferiorização. Durante 1979, as reuniões do Somos eram permeadas por um forte clima de erotismo e muitos participantes ficavam de mãos dadas, trocando carícias ou se beijando. Dizia-se, então, que a naturalidade e descontração dessas ocasiões seriam prejudicadas pela presença de heterossexuais.

Outro ponto sobre o qual parecia haver um consenso bastante forte era quanto à necessidade de se livrar as palavras "bicha" e "lésbica" de suas conotações pejorativas. Para tanto, os integrantes do grupo as usavam constantemente para se referirem a si mesmos e a palavra "homossexual" era quase mal vista, considerada um eufemismo empolado. Evitava-se também as palavras "entendido" e "gay". Essa prática se generalizou a tal ponto em que muitos homens chegavam a se referir ao conjunto de todos os integrantes como "bichas", o que causava protestos por parte das mulheres, as quais diziam que isso 
denotava um esquecimento das especificidades de sua condição. Embora usado de forma cordial entre certos setores do gueto homossexual masculino, a palavra "bicha" ainda ofende a maioria dos homossexuais, que procuram evitá-la para designarem a si mesmos. "Lésbica" é considerado igualmente ofensivo entre muitas das frequentadoras do gueto homossexual feminino. Para vários dos integrantes novos, era um choque o uso dessas expressões e, às vezes, eles até reclamavam disso. Mas tão generalizada era essa prática que, depois de algum tempo, até mesmo os recalcitrantes se conformavam com ela.

Essa atitude de plena aceitação da identidade homossexual, sem recurso a eufemismos, estaria por trás do próprio nome Somos - Grupo de Afirmação Homossexual. Ligado a isto estava também a questão de "se assumir" ou "se enrustir". Esses termos nunca foram muito claramente definidos e havia três níveis em que se podia ser um "homossexual assumido":

a) perante si mesmo;

b) perante o público anônimo;

c) perante a família e colegas de trabalho.

Perante si mesmo e um grupo de amigos próximos: neste nível, o grupo era de grande eficácia, especialmente através dos grupos de identificação. Durante as discussões que giravam em torno de troca de experiências pessoais, os novatos aprendiam a não mais se considerarem seres estranhos. Convenciam-se de que seus problemas e, especialmente, os sentimentos de culpa, que muitos carregavam, eram, em grande parte, o resultado de um preconceito, totalmente carente de fundamentos, que permeava toda sociedade que os rodeava. Em vez de razão de vergonha, dentro desses grupos uma ampla vivência homossexual era até um fator de certo prestígio. Nestas reuniões, eram transmitidas também importantes informações a respeito da subcultura homossexual como: endereços de locais de encontro, as diversas formas de se obter parceiros sexuais, uma iniciação no jargão homossexual e uma apresentação a todo o universo de reflexões sobre a homossexualidade. Como já vimos, era notável a euforia inicial reinante dentro dos grupos de identificação e fortes ligações que se desenvolviam entre seus participantes. Estes frequentemente 
passavam por mudanças positivas muito marcadas em termos de auto aceitação, auto confiança e uma maior eficácia em lidar com o mundo que os cercava. Mesmo que ainda perdurassem receios de se declarar como homossexuais fora das reuniões, o grupo rapidamente se transformava em um ponto referencial, tão importante que chegava a eclipsar, para os seus integrantes, outros mais antigos:

Quando pintou o grupo, foi um grande deslumbramento. Na época eu não tinha turma. Tinha vários grupos de amigos. Em cada um eu era diferente e me sentia perdido com todas estas facetas. No grupo eu me encontrei mais integralmente. (Ulisses)

Outro fenômeno era a transformação pela qual passavam os hábitos dos que participavam dos grupos, muitas vezes deixando de lado suas antigas amizades heterossexuais.

Com o grupo, perdi muitos medos. Agora, acho um saco ter que ir ao cursinho. O grupo está sendo um processo muito mais importante do que o tempo perdido na escola [...]. Com o grupo eu aprendi a vencer certos problemas, a encarar certas pessoas com mais confiança chegando até a fazer algumas cabeças. Porém, o grupo parece ter me causado um esvaziamento cultural. Deixei de ler, de ir ao teatro, etc e agora passo grande parte de meu tempo em boates. (Ricardinho)

Perante o público anônimo: já se falou do clima de erotismo difuso que predominava em muitas reuniões dos grupos homossexuais e da forma costumeira como todos se beijavam na boca ao se encontrarem e ao se despedirem. Uma vez criados esses hábitos dentro de recintos fechados, era quase automática a sua manifestação em locais públicos como áreas do gueto, certos bares, e até nas ruas do centro da cidade. Recusar um beijo ou censurar alguém por falar muito alto sobre homossexualidade, ou por "fechar" demais em público seriam atitudes completamente contraditórias com o teor das discussões mantidas durante as reuniões. Desta forma, alguns militantes mais ousados, ou "pintosos", levam os mais recatados a aderir a certos comportamentos em público que eles dificilmente adotariam espontaneamente. Porém, existia uma preocupação generalizada em não comprometer ninguém em sua vida pessoal e bastava alguém estar perto de seu local de trabalho, moradia, etc., para que todos passassem a controlar ao 
máximo qualquer manifestação aberta de homossexualidade. Como as reações do público anônimo de São Paulo eram geralmente de indiferença, ocasionalmente de espanto misturado com curiosidade e só raramente se ouvia algum comentário zombeteiro ou agressivo, ia-se criando coragem para se deixar reconhecer em público como homossexual. A fonte de maior temor era a polícia, especialmente depois da “Operação Rondão”, da qual se falará mais adiante.

Também ligada a este processo estava a prática de dar entrevistas ou comparecer à faculdade para colocar os pontos de vista do grupo. Quando convidados a ir à Faculdade de Psicologia de Itatiba, por exemplo, compareceram seis integrantes do Somos e dois do Eros. A sala de aula, onde seriam os debates, estava apinhada de gente - umas 200 pessoas aproximadamente - e os representantes dos homossexuais foram acomodados na frente, com cadeiras voltadas para o público. Depois de uma exposição inicial sobre os princípios e estrutura dos grupos, foi aberta uma sessão de perguntas e os militantes presentes passaram a responder sobre as suas formas de encarar a homossexualidade e a opressão. Essas ocasiões exigiam a disposição de se identificar como homossexual perante um grande número de estranhos e eram, geralmente, precedidas de um certo nervosismo. Mas também eram, quase invariavelmente, seguidas de uma euforia e de um sentimento de haver, coletivamente, surpreendido e desarmado um público potencialmente hostil, usando somente as armas da franqueza e da aceitação plena da homossexualidade.

Perante a família e situação de trabalho: neste sentido, além da maior autoconfiança advinda da participação em suas atividades, o grupo não procurava influir no comportamento dos seus integrantes. Comumente, dizia-se que, "se assumir não implica em suicídio" e que cada um sabia como melhor se adaptar à sua situação específica. Reconhecia-se que, em certos casos, o "enrustimento" era a melhor forma de proteção em um meio hostil. É interessante notar a diferença entre essa posição e a de grupos de libertação homossexual de outros países, como os EUA, por exemplo, que chegaram a promover campanhas para os homossexuais usarem distintivos no seu dia a dia, informando a todos à sua volta sobre a sua identidade homossexual. Talvez as razões para essa diferença sejam relacionadas 
com a especificidade de nossa sociedade, que é muito mais autoritária do que a dos EUA ou dos países europeus. Aqui a estabilidade de emprego, por exemplo, é mais precária e o indivíduo se encontra extremamente vulnerável. Igualmente, aqui os laços familiares são mais fortes e a dependência econômica dos filhos tende a ser maior, o que restringe as suas possibilidades de ação dentro de suas casas. Além disso, não se pode esquecer que a própria noção de identidade homossexual é menos cristalizada no Brasil.

Outro ponto sobre o qual parecia haver um consenso bastante amplo no grupo, pelo menos em nível de discurso, era o que dizia respeito ao antiautoritarismo, posição bastante difundida entre os segmentos jovens da população da qual provinham a maioria dos membros do Somos. Porém, as ideias a esse respeito eram pouco elaboradas, raramente indo além de uma posição genérica que, às vezes, tendia a ver qualquer estrutura de poder como intrinsecamente ruim. Em nome do antiautoritarismo, restrições eram feitas tanto aos grupos de direita - universalmente execrados -, quanto aos de esquerda - que, embora fossem olhados com suspeita, contavam com as simpatias de vários integrantes do Somos. Como expressão mais forte dessas ideias, existia a estrutura formal do grupo, criada com a intenção de evitar o aparecimento de líderes. Era instituída uma comissão de coordenadores que, ao menos em teoria, deveria ser mudada mensalmente. Embora isso não funcionasse perfeitamente, pois era difícil encontrar integrantes com tempo e disposição para dedicar às reuniões de coordenadoria, uma preocupação com sua rotatividade era regularmente expressa e os esforços eram feitos para colocá-la em prática.

Os males da sociedade eram atribuídos, em geral, ao autoritarismo, do qual o machismo e o racismo seriam duas manifestações. Muitas vezes, as expressões "machista", "fascista" e "autoritário" eram usadas indistintamente, demonstrando uma elaboração muito simplificada do conceito de machismo. Como já vimos, por ocasião da promoção de uma festa exclusivamente lésbica que se seguiu a uma das primeiras grandes reuniões gerais do Somos em 1979, várias mulheres do grupo começaram a reclamar de expressões de machismo que seriam correntes no grupo. Uma das piores, segundo elas, seria a tendência a ignorar as necessidades específicas das lésbicas, quando não a sua própria 
existência dentro do Somos. Posteriormente, isso levaria a grandes disputas, entre alguns membros dos grupos masculinos e femininos, quando se discutia a questão do separatismo lésbico.

As mulheres do grupo criticavam especialmente o hábito de alguns dos homens de se referirem à totalidade do grupo como composto por "bichas". Insistiam que se usassem os termos "bicha e lésbica". Elas, igualmente, repudiavam o uso da palavra "rachada", termo pejorativo usado no gueto homossexual masculino para designar mulheres. Suas aspirações eram vistas, por muitos homens, como perigosamente enfraquecedoras do movimento e como se estivesse roubando do grupo possibilidades de descobertas a respeito do sexo oposto e seus problemas, que todos diziam achar muito enriquecedores. A resposta que as mulheres e alguns homens, geralmente "veteranos" aliados seus, davam a essas alegações era de que elas obedeciam à mesma lógica que as acusações dos partidos políticos ortodoxos, que enfatizavam a unidade e criticavam as organizações feministas e homossexuais, por serem divisionistas.

Existia também outra manifestação da preocupação com o machismo, manifestado mais no plano comportamental que no discursivo e que se referia ao desempenho dos papéis sexuais. Dentro do Somos nunca houve uma preocupação em promover uma divisão sexual de tarefas a serem executadas. A única ocasião em que a diferença entre os sexos era formalmente reconhecida, antes do surgimento de um subgrupo exclusivamente lésbico, era por ocasião da escolha de representantes ou coordenadores de reuniões. Nessas ocasiões, sempre se enfatizava a importância de haver representantes de ambos os sexos.

Quanto à questão da "masculinidade" ou "feminilidade" do comportamento pessoal de seus membros, o Somos sempre refletiu o padrão encontrado entre a juventude de nível colegial ou universitário. Uma grande parte dos integrantes costumava usar a calça jeans e camiseta, que eram quase o uniforme de sua geração, e suas posturas corporais, movimentos e tom de voz, geralmente eram iguais aos de seus pares heterossexuais. Era comum ouvir pessoas de fora do grupo expressarem surpresa e até desapontamento perante a falta dos trejeitos e roupas espalhafatosas, que imaginavam ser a marca da homossexualidade. 
Isto não quer dizer que inexistiam, no Somos, homens que se aproximavam do estereótipo do "efeminado". Eram as chamadas "bichas pintosas", que, ocasionalmente, reclamavam que estariam sendo discriminadas pelos outros integrantes do grupo. Esta é uma discriminação encontrada costumeiramente no mundo homossexual de São Paulo, onde a apresentação viril é bastante valorizada. (PERLONGHER, 1987) O próprio Somos reiterou sua posição diversas vezes contra esse preconceito, lembrando sempre que foram os homossexuais mais óbvios e mais escandalosos os que abriram os espaços, agora ocupados por todos. Porém, depois de uma convivência prolongada no grupo "as pintosas” pareciam se tornar mais sóbrias, apesar de não haver nenhuma pressão explícita a empurrá-las neste sentido. No boletim interno do grupo, Leva e traz, $\mathrm{n}^{\circ}$ 1, editado em 19 de maio de 1980, publicou-se o seguinte texto que refletia as ideias, geralmente expressas dentro do grupo, sobre o problema da "desmunhecação" e das "bichas pintosas":

- Onde está o problema de desmunhecar?

Somos educados numa sociedade heterossexual que exige, de homens e mulheres, expressões corporais muito distintas, que exige, inclusive, uma verbalização muito distinta para cada sexo.

Mesmo na dança, que seria uma forma de descontração, os papéis são muito diferentes. E, se à mulher se permite então uma liberdade maior de gestos, cabe ao homem uma postura mais rija, mais rígida e algumas regiões do corpo têm de ser esquecidas.

E qualquer "invasão" de um dos sexos, no âmbito de comportamento do outro, tende a ser logo reprimida, se usando para isso da classificação de comportamento ridículo ou anormal, sem qualquer questionamento do que possa significar "normal". Me parece que isso revela um comportamento maniqueísta, heterossexual: pessoas propensas a taxar todas as coisas de certo ou errado, normal, segundo padrões sociais preestabelecidos.

Mas este tipo de preconceito não deveria pintar nas cabeças homossexuais. Afinal, nós também somos o que usualmente se classifica de anormal, o que gera logo uma pergunta - anormal por quê?

$\mathrm{O}$ fato de a nossa transa ser com pessoas do mesmo sexo torna o nosso desejo, o nosso amor, o nosso prazer menos legí- 
timo? E se procurarmos na cama uma expressão sexual que nos dá muito prazer, mas foge aos padrões, no mínimo deveríamos ter um respeito muito grande por quem, através de roupas, de gestos e falas, também procura se expressar diferentemente.

Acho que as bichas pintosas ou os travestis, ou as lésbicas tipo macho são pessoas corajosas, que subvertem o padrão hetero que nos é cobrado a cada instante. Não importa o motivo que leva a isso - a busca de aceitação, ou a agressão, a identificação com o outro sexo ou com um estereótipo. O que importa realmente é que são pessoas que estão procurando uma expressão mais verdadeira de si próprias e assumir publicamente essa postura é um ato revolucionário de grande importância.

Se é verdade que, no grupo, as "bichas pintosas" às vezes se tornavam mais sóbrias, também deve ser lembrado que o processo de "desenrustimento" motivado pelo contato com o coletivo levava muitos homossexuais masculinos a terem menos medo da estigmatização. Sentindo-se mais livres e desejosos de manifestar sua identificação com o Somos, ou com os homossexuais em geral, em certas ocasiões passavam a adotar um comportamento "fechativo", que anteriormente lhes seria inconcebível.

Outro aspecto importante da atitude corrente dentro do Somos, em relação à questão dos papéis de gênero, era aquele relacionado com a adoção de um modelo "igualitário" para categorizar a sexualidade, já discutido anteriormente. (FRY, 1982, p. 87) Provavelmente, um grande número dos integrantes do grupo já adotava esse modelo antes mesmo de conhecerem o Somos. Possivelmente, seria por essa sua concepção igualitária que eles se interessariam pela ideia de reivindicar um tratamento mais democrático para os homossexuais. Outros que, ao ingressarem no grupo, ainda usavam o esquema hierárquico, geralmente se convertiam rapidamente ao modelo mais igualitário.

Entre os militantes homossexuais, tanto do Somos quanto da maioria dos outros grupos que surgiram no Brasil, as noções de "ativo" e "passivo" eram ridicularizadas. Apesar disso, vários deles admitiam que, em nível de fantasia, essas categorias continuavam a ser importantes, mas, mesmo esses, recusavam-se a admitir qualquer tipo de hierarquização de papéis sexuais "fora da cama”. Embora alguns dissessem preferir ser ativos ou passivos, dentro do Somos dava-se 
muito valor à variedade, tanto de parceiros quanto de formas de desfrutar os prazeres do sexo. O “machão", protótipo do ativo, apesar de ser desejado sexualmente por muitos homens do grupo, não era levado a sério e circulavam histórias sobre homens de apresentação hiper masculina, que, na hora do sexo, pediam para ser penetrados. Muito comentados, também, eram os casos de travestis que comumente eram pagas por seus clientes para adotar o papel ativo.

Mas, enquanto todas as possibilidades da sexualidade homossexual eram discutidas e exploradas, o bissexualismo, isto é, o relacionamento sexual indiscriminadamente homossexual ou heterossexual, não recebia nenhum endosso. Especialmente nos primeiros tempos, integrantes do Somos que diziam ter relacionamentos heterossexuais eram ligeiramente mal vistos e encontraram pouquíssimo apoio. Existia uma corrente de pensamento bastante forte que negava a existência de uma categoria de bissexuais. Eles seriam simplesmente homossexuais que, por falta de coragem de se assumirem plenamente enquanto homossexuais, usariam relacionamentos heterossexuais como disfarce. Similarmente argumentava-se contra o uso do termo "bissexual". (TREVISAN, 1986, p. 21)

Esta discussão sobre o comportamento durante o ato sexual e a sua valorização é mais aplicável aos homens do grupo que às lésbicas, sobre quem me foi mais difícil obter informações neste sentido. Mas, sobre elas, posso afirmar que as integrantes do Somos diferenciavam-se muito, em seu comportamento, das mulheres que podiam ser encontradas nos poucos locais públicos frequentados por lésbicas em São Paulo por volta de 1980. Nestes locais, a norma era encontrar uma reprodução muito mais restrita do comportamento heterossexual. Essas lésbicas assumiam os papéis de lady - a parceira que faz o papel de "mulher" - ou de fanchona - a parceira que faz o papel de "homem". Esses relacionamentos, às vezes, chegavam a níveis quase caricaturais, com as fanchonas se esforçando ao máximo em imitar homens, chegando, em casos extremos, a usar cuecas, adotar gestos bruscos e a tratar as "suas mulheres" de acordo com os padrões machistas vigentes na sociedade.

As mulheres do Movimento Homossexual diziam que a maioria das lésbicas eram muito menos visíveis que os homossexuais masculinos. 
Assim, comparar as militantes às ladies e fanchonas, talvez seja tão errado quanto comparar os homens do grupo às travestis ou aos michês. Em geral, as atitudes das lésbicas militantes eram bastante parecidas às dos homens dos grupos homossexuais; davam grande importância ao aspecto democrático e não demonstravam desejo de se parecerem com o sexo oposto. Ao contrário, as suas atividades feministas as levaram a valorizar ainda mais tudo que era ligado à mulher.

Outro aspecto do desempenho de papéis é o relacionado às várias formas possíveis de ligações afetivas sexuais encontradas entre os integrantes do Somos e dos outros grupos saídos dele. Novamente, aqui terei que me ater mais ao caso dos homens porque, neste campo, me foi difícil apreciar a prática das mulheres. Entre os homens dos grupos homossexuais, sempre reinou um espírito de hedonismo e havia uma postura bastante generalizada de incitação permanente ao sexo, não importando se com parceiros de dentro ou de fora do grupo. Porém, continuava-se a dar grande valor ao antiautoritarismo e nas raras vezes em que se faziam críticas sobre o comportamento sexual dos integrantes do grupo, estas eram direcionadas contra manifestações de dominação ou possessividade de um parceiro por outro. Aqui, o termo pejorativo "galinha", muito usado em meios homossexuais para indicar reprovação sobre o comportamento de indivíduos considerados demasiadamente promíscuos ou inconstantes, deixava de ter uma carga negativa, nas poucas vezes em que era empregado. Talvez, grande parte dos militantes não tivesse "casos", ou seja, ligações mais duradouras com uma pessoa em particular.

A atividade sexual desses se daria através de encontros mais ou menos passageiros com indivíduos "caçados" nas ruas, nos bares, boates e saunas do gueto homossexual e até em certos cinemas e banheiros públicos. Embora alguns destes manifestassem o desejo de terem um "caso", muitos diziam não sentir necessidade disso.

Entre aqueles que tinham um "caso", alguns se definiam como em "relacionamento aberto", o que lhes permitia ter atividades sexuais com outros. Este tipo de relação era bastante admirado dentro do Somos e de outros grupos homossexuais, embora muitos dos que o elogiavam confessassem ainda não ter "estrutura para isso". Existiam também os "casos fechados", em que relacionamentos sexuais 
fora da relação não eram tolerados e, quando ocorriam, tinham que ser mantidos secretos. A desonestidade de um parceiro com outro, revelada nestas situações, era, geralmente, ridicularizada pelos demais militantes.

Outra manifestação de autoritarismo da sociedade à qual o Somos se opunha era o racismo, especialmente aquele dirigido contra negros e índios. Um dos grupos com o qual o Somos mantinha diálogos era o Movimento Negro Unificado, considerado por muitos como um importante aliado. Entendiam que esse movimento lutava contra um preconceito que, assim como o machismo, afetava o seu alvo de forma total, restringindo suas possibilidades no campo sócio econômico e chegando a penetrar nos recessos mais recônditos da psique, no qual produzia o "negro de alma branca", considerado análogo ao "homossexual enrustido". Assim como as feministas e os homossexuais, os negros também teriam reivindicações específicas. Devido a sua posição "minoritária" teriam de enfrentar constantemente as organizações de oposição político partidária, que os criticavam por serem divisionistas e tentavam englobá-los em uma luta maior, na qual suas reivindicações seriam necessariamente subordinadas a outras consideradas mais gerais.

Os contatos entre os movimentos homossexual e negro geralmente ocorriam em debates sobre as "questões das minorias" e em atos públicos, especialmente aqueles de protesto contra a violência policial, como a passeata realizada contra a "Operação Rondão", em 1980, relatada mais adiante. Deve-se lembrar, também, que a primeira aparição do Somos em passeata foi por ocasião do Dia de Zumbi, celebrada pelo Movimento Negro Unificado em 1979. Apesar destes pontos de contato, dizia-se que o machismo seria muito forte entre os negros e que o movimento homossexual não havia sido capaz de fugir por completo do racismo generalizado na sociedade brasileira. Dentro do Somos, o problema do racismo foi raramente discutido até meados de 1980, quando alguns de seus integrantes negros tentaram formar o Grupo dos Negros Homossexuais, visando atuar dentro dos dois movimentos.

O movimento indígena e a Comissão Pró Índio, de São Paulo, também contavam com as simpatias do Somos. Suas lutas eram, 
ocasionalmente, invocadas de maneira genérica e seus representantes convidados a participar tanto de abaixo assinados, quanto de debates. Este relacionamento, porém, raramente passou do nível de apoio formal.

Uma das principais fontes de inspiração, para essa política de alianças com outros grupos com reivindicações específicas, foi o jornal Lampião. Como Trevisan, um dos propulsores dessa política do jornal, era também uma importante liderança do Somos, essas ideias foram levadas para reuniões do grupo e geralmente aceitas em consenso geral.

Outra influência para a política de alianças foi a atuação dos elementos ligados às organizações de esquerda engajadas na luta partidária, especialmente as trotskistas. Dessa forma, a primeira participação do Somos na comemoração do Dia de Zumbi, em 1979, foi incentivada por Charlie, militante da Convergência Socialista.

Na carta de princípios, intitulada "Nossa Proposta", também usada como apresentação do grupo durante o ano de 1979, explicitava-se a crença na necessidade de "uma profunda transformação social que ponha fim à divisão de classes dentro da sociedade, sejam elas econômicas ou sexuais". Para tanto, seria necessário que os homossexuais encontrassem seus "próprios caminhos" e a mudança teria que se iniciar neles próprios, na luta contra o machismo e autoritarismo que eles também carregariam. Além dessas ideias, pouco mais era dito sobre como se promoveria tão grandes mudanças na sociedade e, nas conversas informais, transparecia muitas vezes a ideia de que a própria luta pelos direitos dos homossexuais acabaria por provocá-la. Essa concepção do poder da sexualidade em regulamentar o resto das relações sociais, remete ao comentário de Foucault: "O que me parece essencial é a existência em nossa época, de um discurso onde o sexo, a revelação da verdade, a inversão de lei do mundo, o anúncio de um novo dia e a promessa de felicidade estão ligados entre si”. (FOUCAULT, 1979, p. 13)

Aí parece estar resumido o cerne do ideário do Somos. 


\section{As crises do Somos e a defesa do Lampião}

No decorrer do primeiro semestre de 1979, o Somos parecia atingir a condição de um verdadeiro grupo político, dotado de dinâmica própria, deixando de ser um simples círculo de amigos que só existia em função de um ou dois líderes. Estavam ocorrendo mudanças qualitativas, não só no seu interior, como na sociedade como um todo, e logo surgiram sinais de que a maneira de funcionar do grupo dificultava sua adaptação às novas circunstâncias.

Inicialmente, o grupo encontrou uma importante fonte de motivação na experiência de fraternidade exacerbada que, usando a terminologia de Turner (1974), poderíamos chamar de "comunitas existencial ou espontâneo”. Este, porém, tende a ser de duração efêmera e qualquer grupo que almeje conservá-lo como sua fonte inspiradora acaba tendo que adotar algum tipo de organização que o preserve diante das influências do tempo, da necessidade de mobilização e de arranjo de recursos, assim como da necessidade de controle social entre seus membros. Turner chama de "comunitas normativo" esse tipo de organização, afirmando ser o destino histórico de quase todo "comunitas espontâneo", cair na estrutura e na lei. (TURNER, 1974, p. 120) Embora muitos dos integrantes do Somos desejassem perpetuar a união entre a 
militância e o prazer, evitando o surgimento tanto de lideranças quanto de massas de manobras, logo começaram a ficar evidentes as dificuldades inerentes à proposta de se manter por tempo indeterminado, um grupo sem hierarquia e sem estrutura, no qual a atuação política se baseasse prioritariamente no reconhecimento do valor único da individualidade de cada um de seus membros. Por mais nebulosos que fosse, o grupo tinha certos objetivos a serem cumpridos e esses, assim como suas pretensões à permanência, tornavam necessário algum tipo de estruturação.

A fase de transição, em que comunitas se transforma em "estrutura”, é dolorosa para os que dela participam. No caso do Somos, seus integrantes logo começaram a perceber crises no grupo. Essas eram potencializadas pela dor que acompanha a mudança de um tipo de relacionamento carregado de uma dose muito forte de afetividade para uma vida estruturada, em que decisões têm que ser tomadas, preferências pessoais sacrificadas perante as necessidades coletivas e quando obstáculos físicos ou pessoais só podem ser ultrapassados a custo. Como diz Turner (1974, p. 127):

A grande tentação humana, encontrada proeminentemente
entre os utopistas, é de negar-se a desistir das qualidades
boas e agradáveis daquela fase (comunitas) para abrir cami-
nhos para o que podem ser os sofrimentos e perigos neces-
sários para a próxima. O comunitas espontâneo tem algo de
mágico. Subjetivamente ele carrega o sentimento de poder
ilimitado. Mas este poder se não for transformado não pode
ser aplicado aos detalhes organizacionais da existência so-
cial. Não é um substituto para o pensamento lúcido e a von-
tade sustentada.

Tornava-se mais necessário adotar certas medidas que fortalecessem a organização do Somos, enfatizando inevitavelmente os aspectos de militância às custas do prazer.

\section{O Somos começa a se burocratizar}

O crescimento numérico dos integrantes do grupo foi um dos importantes geradores dessa tensão. Até então, o número reduzido de seus militantes possibilitava um relacionamento pessoal e direto entre 
todos, mesmo quando participando de subgrupos diferentes. Era comum, por exemplo, no final das reuniões de identificação, a maioria das quais ocorria nos sábados à tarde, que os seus participantes saíssem em grandes turmas para jantar em restaurantes da área do Centro. Nesses momentos, quando imperava um clima de grande descontração e amizade, trocavam-se informações sobre o andamento dos vários subgrupos. Mas, aos poucos, com a proliferação de novos subgrupos de identificação, esta prática foi deixando de ter a característica de se estender a todo o Somos, para tomar um caráter de reuniões restritas, de pequenas redes de amizade, dentro do grupo maior.

Várias "panelinhas" informais foram se cristalizando, enquanto os elos de amizade entre elas se enfraqueciam. Neste processo, tornou-se problemático um dos subgrupos de identificação que fazia reuniões afastadas do Centro e era composto quase exclusivamente por pessoas novas ao Somos. Como, além de tudo, seu coordenador, Glauco Mattoso, não sentisse grande satisfação com o cargo de servir de elo com o resto do grupo, este subgrupo foi, aos poucos, se desgarrando do corpo do Somos. Pela primeira vez no grupo, enfrentava-se a existência de membros que não só não podiam ser realisticamente tratados como amigos íntimos, mas, pior que isso, em muitos casos, nem ao menos eram conhecidos de vista dos outros.

O crescimento desordenado também causava problemas para o próprio "processo de identificação", pois a constante entrada de militantes novos rompia a continuidade entre uma reunião e outra. Parecia que toda semana ocorria uma repetição da reunião anterior, com a já ritualizada apresentação dos indivíduos que davam alguns dados pessoais de forma cada vez mais concisa e entediada. As discussões tornavam-se infrutíferas, versando sempre sobre os mesmos temas: a falta de objetivo explícito do Somos, a necessidade de se excluir heterossexuais, o perigo que representava para os homossexuais a subordinação de sua luta à chamada "luta geral", etc. Estas dificuldades logo começaram a levar algumas pessoas a pedir que os subgrupos se fechassem e que se instituísse alguma forma mais ordenada de acomodar integrantes novos.

Como já vimos, para tentar resolver os problemas causados pelo ingresso de novos membros no Somos, criou-se a instituição de 
"reuniões de recepção" regulares, que resultavam na formação de novos subgrupos de identificação, sob a coordenação de veteranos do grupo. Em pouco tempo, havia vários subgrupos em funcionamento, todos bastante autônomos, pois a única subordinação formal que todos aceitavam era à reunião geral, que deveria ocorrer mensalmente, com a participação de todos os integrantes do Somos.

Rapidamente, ficou claro que esse arranjo era bastante ineficaz, se o que se pretendia era levar adiante uma atuação mais concreta, além do chamado "processo de identificação", como desejavam os participantes do subgrupo de atuação externa. Na falta de uma entidade mais representativa do grupo como um todo e habituado a falar em nome do Somos, quando assinando cartas de protesto, participando de debates, etc, esse subgrupo começou a tomar para si a função de coordenação informal do Somos. A consolidação definitiva deste papel foi dada pela incumbência de organizar as reuniões gerais. Esta tarefa não era nada fácil, exigindo experiência e contatos amistosos com outras entidades, dada a necessidade de sempre se achar um local emprestado para essas reuniões. Em se tratando de um grupo de homossexuais, a tarefa se tornava ainda mais difícil, devido ao forte preconceito social contra eles. Assim, acabavam gravitando para este subgrupo alguns dos militantes mais dinâmicos e experientes, entre eles vários dos fundadores do Somos.

Pertencer ao subgrupo de atuação começou a ser uma marca de prestígio, mas, embora ele fosse formalmente aberto a todos os integrantes do Somos, somente homens e mulheres com mais autoconfiança ousavam participar de suas reuniões. O hábito de organizar as reuniões gerais logo levou os integrantes desse subgrupo a quererem estender seu poder para as reuniões semanais de identificação, exigindo que um espaço de tempo fosse reservado para informes sobre a situação do grupo em geral e sobre as atividades de atuação. A ingerência nas atividades dos subgrupos de identificação chegou ao ponto de se tentar instituir uma programação comum de tópicos a serem debatidos por todos, atrapalhando, desta forma, o fluxo espontâneo das discussões de cada um. Dentro do próprio subgrupo de atuação, havia uma tendência a surgirem líderes informais, mas altamente carismáticos. Apesar do comando exercido por eles ser de natureza não 
oficializada e de serem frequentes suas próprias denúncias do papel que lhes estaria sendo imposto, esses acabavam tacitamente assumindo a liderança e, eventualmente, até brigavam por ela, embora geralmente de forma velada.

Vários fatores, alguns mais circunstanciais, outros menos, causavam essas situações. Havia, por exemplo, a falta de locais disponíveis para reuniões, levando a maioria delas a serem realizadas na moradia de uma das poucas pessoas que dispunha de casa em que não residiam outras pessoas contrárias a essas reuniões e onde não havia o problema de porteiros repressores ou bisbilhoteiros, encontrados na maioria dos prédios de apartamentos. ${ }^{1}$ Obviamente, o morador de tal casa encontrava-se em uma posição privilegiada para controlar o grupo. Aqueles integrantes que não se davam bem com ele tinham poucas opções, além de deixar de ir às reuniões. Outro fator importante era o acesso, ou não, a um telefone. Como a maioria dos contatos e a divulgação de informações eram feitas de forma informal e verbal, aqueles que tinham telefone recebiam mais informações e podiam divulgar suas opiniões mais facilmente.

A disponibilidade de tempo também era crucial e podia-se constatar que os membros mais ativos, e portanto mais influentes em dados momentos, eram pessoas desempregadas ou subempregadas. $\mathrm{O}$ ativismo homossexual revelou-se uma boa maneira de preencher o vazio existencial causado por estas condições e, havendo tempo disponível, sempre surgia alguma coisa que precisava ser feita. Em vários casos, estudantes deixaram cursos frustrantes para dedicarem mais tempo ao Somos e alguns até largaram seus empregos. Prestígio no mundo externo também era um fator importante, especialmente quando usado para conseguir vantagens para o grupo. Em nível mais pessoal, também pareciam ter importância o desenvolvimento intelectual e a habilidade de se expressar bem. Reflexo disso, temos o fato de que, quando alguns destes líderes passaram a ser questionados, falava-se na "tirania dos seus belos discursos".

1 Durante parte desse periodo vigorou um ordenamento em que os porteiros de prédios deveriam entregar relatórios à polícia sobre visitantes que pernoitassem nos apartamentos e outros eventos suspeitos ou fora do normal. 
De importância primordial também era o grau de simpatia e facilidade de relacionamento. Dentro de um grupo como esse, que se declarava empenhado em valorizar o prazer e o "tesão", não deixavam de ser notáveis as vantagens auferidas por aqueles que eram percebidos como "bonitos" ou "gostosos". Mesmo em casos de franco desentendimento e desacordo total de ideias, integrantes do Somos muitas vezes se deixavam influenciar por charmes físicos ou de personalidade. Como o "tesão" era considerado por muitos um valor supremo, capaz de justificar quase tudo, esse fato não era comumente criticado. O que era ocasionalmente questionado era a manipulação consciente de dotes pessoais para a obtenção de fins não ligados ao prazer sensual ou afetivo, como aconteceu com as acusações levantadas contra um militante da Convergência Socialista, criticado por praticar "política de cama" para difundir suas ideias dentro do Somos.

A posição de liderança do subgrupo de atuação externa se consolidou fortemente durante a primeira metade de 1979, mas ela sempre encontrou resistência em alguns setores. Eram constantes as reclamações dos subgrupos de identificação, por exemplo, contra o "desperdício de tempo" de suas reuniões com a sessão de informes do grupo. Também, foram levantadas objeções ao documento intitulado $A$ nossa proposta, escrito por um integrante da atuação externa, assim como se faziam questionamentos sobre tabu contra a participação de heterossexuais nas reuniões e em outras atividades do grupo. Como já vimos, muitos dos recém-ingressos no Somos também estranhavam o uso das palavras "bicha" e "lésbica", como forma de auto referência, acostumados que estavam a entender esses termos como pejorativos. Outros questionavam a postura "anarquista" do grupo, pedindo definições mais claras dos seus objetivos e explicações sobre os deveres e direitos de cada integrante.

Aos poucos, foi aumentando a contradição entre os ideais antiautoritários, constantemente divulgados pelos membros da atuação externa, e sua maneira de agir na prática. A contradição se acirrava diante da necessidade sentida por aquele subgrupo de coordenar e uniformizar as atividades do Somos, sob o pretexto de que seria necessário evitar que o crescimento contínuo o levasse ao esfacelamento. A crescente centralização e a diminuição do contato direto e 
pessoal entre todos os integrantes do grupo, agora cada vez mais difícil devido aos inúmeros envolvidos, levava muitos, especialmente os recém-ingressos, marginalizados do centro de decisões, a crer que o grupo se burocratizava demasiadamente.

\section{A manipulação do "feminismo"}

O Somos começava a ser tomado por um sentimento de mal estar generalizado e várias causas eram apontadas. Um dos pontos de atrito, logo levantado, foi a situação das mulheres, que se sentiam demasiadamente dispersas entre os vários subgrupos, nos quais se encontravam invariavelmente em menor número. Isso, alegavam, tornava difícil desenvolver dentro do Somos uma consciência sobre as necessidades específicas das lésbicas. Diziam que, na sua condição de duplamente oprimidas, - como mulheres e como homossexuais - teriam algumas reivindicações diferentes das dos homossexuais masculinos que, apesar de sofrerem discriminações e opressões em virtude de sua orientação sexual, nem por isso deixariam de ter um comportamento machista, que seria inerente a todos os membros da sociedade e especialmente aos homens.

A questão começou a polarizar todas as tensões do Somos. A proposta de algumas mulheres de formar um subgrupo de lésbicas, fechado aos homens, provocou muita controvérsia e indignou alguns. Os mais contrariados eram os homens recém-admitidos no grupo e algumas mulheres que também tinham desentendimentos pessoais com as que faziam essas reivindicações, que começaram a ser consideradas frutos de um "feminismo radical". Essa acusação era devolvida pelas "radicais", que acusavam todos os que discordavam delas de serem "machistas". A partir daí, durante alguns meses, "machismo" passou a ser uma palavra usada para explicar todos os males que assolavam o grupo e era usada indiscriminadamente contra homens, mulheres, "bichas pintosas", "bichas enrustidas", pessoas engajadas na política partidária, etc.

Como antídoto ao "machismo", surgiu a ideia de se estudar o feminismo, concebido por muitos como uma espécie de panaceia universal, mas cujos conceitos básicos eram desconhecidos por quase todos os 
integrantes do grupo. Mesmo as poucas pessoas que tinham contato mais próximo com os grupos feministas de São Paulo tendiam a considerar aquelas organizações como demasiadamente voltadas para a "luta geral", além de terem preconceitos anti-homossexuais. Somente o grupo Nós Mulheres contava com mais simpatia, pois, durante a Semana das Minorias da Universidade de São Paulo (USP), sua representante tinha sido atacada de forma parecida com a dos homossexuais.

Dentro do Somos, a defesa do "feminismo" se apresentou como uma arma preciosa para a liderança informal, cuja influência estava sendo questionada. Além disso, tornara-se senso comum dentro do coletivo que, enquanto visão de mundo, o marxismo tradicional dos opositores mais ferrenhos do regime militar não seria capaz de dar conta satisfatoriamente da experiência homossexual. Mas um grupo do tamanho do Somos, que já contava com 80 a 100 integrantes, precisava acreditar na existência de alguma forma de explicação para a sua condição, mesmo que só alguns poucos realmente estivessem familiarizados com ela. Nesse momento, foi amplamente alardeado que tal explicação seria encontrada no "feminismo", generalizando-se a crença de que a teoria feminista teria a chave da solução dos problemas do grupo. Dessa forma, a "cúpula" do Somos pôde, mais uma vez, legitimar sua ascendência através da detenção do poder do saber, uma vez que eram eles os que conheciam melhor aquela teoria.

A desagregação do Somos era uma possibilidade que parecia se tornar cada vez mais real. Durante os feriados de Corpus Christi (14 a 18 de junho) deste mesmo ano de 1979, foi promovida uma excursão visando reaproximar os integrantes do grupo e tornar conhecidos de todos um novo subgrupo de identificação que manifestava grandes sinais de rebeldia contra decisões do subgrupo de atuação. Várias tentativas de explicação eram propostas para esse fenômeno. Alguns diziam que seria um grupo "naturalmente fútil", outros atribuíram as diferenças ao fato desta "nova geração" ter entrado para o rupo quando ele já se encontrava formado e que, portanto, eles estariam menos identificados com seus ideais, não tendo que "lutar por eles" durante a fase de construção dos Somos. Por fim, corria a ideia de que esse subgrupo estava mais isolado dos outros, em termos geográficos e que 
faltaria a ligação afetiva, tão enfatizada por alguns dos fundadores do grupo, entre seus integrantes com o resto do Somos.

Um dos membros do grupo colocou então à disposição do grupo uma casa de campo de sua família em Campos do Jordão, não muito distante de São Paulo, onde todos poderiam passar o feriado juntos. Sua oferta foi aceita e, embora a casa não dispusesse de muitos cômodos, era bastante ampla e foi possível acomodar nela trinta pessoas, incluindo seis mulheres.

Nessas condições era inevitável um certo desconforto e equipes tiveram que ser organizadas para cuidar de tarefas como cozinhar, manutenção da limpeza, etc. Logo surgiram reclamações sobre a rigidez dessa organização e sobre a obrigatoriedade do comparecimento às assembleias matinais realizadas entre 10:30 e 11 horas, convocadas por integrantes do subgrupo de atuação, para resolver questões financeiras, geralmente relacionadas ao planejamento do cardápio do dia. Muitos criticaram o que julgavam ser um burocratismo excessivo, reclamando contra a interrupção de seu sono ou de suas relações sexuais.

Além de argumentar que certas decisões precisavam ser tomadas em conjunto para evitar qualquer "autoritarismo", alguns membros do subgrupo de atuação alegaram que o Somos estaria acometido de "machismo" e "alienação". Quando se propôs discutir essas questões, a maioria dos presentes protestou dizendo que estavam lá "para se divertir e não para fazer militância".

Durante grande parte do feriado, reinou um clima de compreensão entre a maioria dos presentes, mas houve um incidente em que ânimos se exaltaram e ficou comprovado que o clima de comunitas seria difícil de restaurar. Tudo começou quando um grupinho, contando com a presença maciça dos integrantes do subgrupo "rebelde", resolveu fazer um passeio pela cidade. Um número grande de homossexuais juntos, inevitavelmente, chama a atenção do público e uma mulher desconhecida começou a fotografar "as bichas fechando". Ao perceber isso, alguns dos membros do "subgrupo problema" foram conversar amigavelmente com ela, posando em atitudes caricaturalmente homossexuais. Alguns dos seus parceiros de passeio criticaram o "papel de palhaços" que estavam fazendo e ficaram mais irritados ainda ao ouvirem a fotógrafa e seus amigos serem convidados para filmar 
uma festa junina, que estava sendo preparada na casa para aquela noite. A ameaça de uma "invasão de heterossexuais" deixou muitos alarmados e alguns líderes informais do grupo começaram a emitir opiniões contrárias ao costume de "fechar". Alegavam que estavam ocorrendo expressões de alienação e machismo por parte de alguns homens, que, por brincadeira, se diziam mulheres ou então usavam expressões misóginas, como "rachada", para designar o sexo feminino. Muito criticado foi um rapaz que fazia referências constantes à sua "chana" - vagina na gíria lésbica - enquanto outros faziam strip-teases e andavam pela casa nus, ou com cuecas minúsculas, adotando posturas supostamente lascivas ou femininas. Falava-se em "vulgarização do corpo" ou em "uso de uma linguagem corporal desprovida de sentido".

O incidente com a fotógrafa foi motivo de grandes discussões e a maioria dos integrantes do subgrupo de atuação foram muito criticados, especialmente por aqueles que estavam há menos tempo no Somos e que achavam que o incidente não passara de uma inofensiva brincadeira. Os ânimos ficaram tão exaltados que Raimundo, um dos principais líderes informais, chegou a chorar. Uma das figuras mais polêmicas do grupo, ao mesmo tempo muito querido e respeitado por alguns, mas chamado de autoritário por outros, ele foi muito atacado durante esse feriado, sendo até chamado de "aiatolá", durante uma reunião matinal, o que causou muito riso da parte dos presentes. Outro ataque que sofreu, obviamente relacionado à sua preocupação em detectar machismo no Somos, foi uma inscrição anônima no mural, que ele mesmo havia colocado, para permitir a livre expressão de sentimentos do grupo. Esta inscrição dizia: "Raimundo, o que a bicha precisa fazer para não ser machão?”. O mesmo mural continha outras inscrições críticas, como: "Quando a gente imagina/acredita que encontrou o lugar, clima, pessoas legais, pinta a repressão - super chato”.

Mas não foi somente o suposto autoritarismo dos principais organizadores da excursão, que foi criticado. Durante as reuniões matinais, muitas críticas disfarçadas de brincadeiras ocorreram. A certa altura, por exemplo, um rapaz, realçando sua aparência feminina com o uso de uma túnica, um pouco de maquilagem e uma mudança de penteado, assumiu o papel de mestre de cerimônias, adotando o 
nome de "Bixênia" - paródia do nome da apresentadora de programas femininos na rádio e TV, Xênia Bier. Quando todos se apresentavam seguindo a fórmula de praxe dentro do grupo - nome, idade, trabalho, signo zodiacal e "estado civil" - ele fazia comentários maliciosos. Estes versavam, geralmente, sobre o item "estado civil”, quando os presentes deveriam se declarar comprometidos, ou não, com uma pessoa em especial. A maioria se declarava "solteira", mas vários se disseram "casado em regime aberto", o que provocava aplausos e outras manifestações de aprovação por parte da audiência. Quando um dos integrantes do subgrupo de atuação se apresentou como "casado em regime fechado", Bixênia comentou: "Fechado pela frente e aberto por trás", causando grande hilaridade e levando o rapaz em questão a criticar a "demagogia" que estaria sendo feita a respeito dos "casos abertos".

Também, no tocante à questão da fidelidade entre pessoas "de caso", surgiram alguns conflitos. Imperava uma grande promiscuidade libidinosa e, como da vez anterior, em Praia Grande, muitos dos participantes mantiveram relações sexuais com múltiplos parceiros. Até a orientação exclusivamente homossexual do grupo chegou a ser transgredida e, se não houve ato heterossexual consumado, chegou-se muito perto disso. Todos se beijavam, se roçavam e muitos apalpavam a genitália ou os seios uns dos outros. Especialmente entre as mulheres, até então mais adeptas da exclusividade sexual, vários "casos se abriram". Todos incentivavam a libidinagem e o clima era francamente de orgia.

Porém, nem tudo foi compreensão e amizade. Um dos integrantes mais recentes, um homem aparentando 40 anos - ele não quis dizer sua idade -, visto por todos como sendo "de outra geração", manifestou uma visão mais "careta" sobre a homossexualidade e declarou sua intenção de deixar o Somos, pois haviam "roubado a sua transa" - um rapaz com quem ele havia planejado passar a noite, acabou dormindo com outro, acontecimento corriqueiro durante esses dias. Até os dois rapazes que haviam se declarado "casados em regime fechado" acabaram tendo um desentendimento, motivado pelo passeio de um dos parceiros com outro do grupo. Esses incidentes foram isolados, mas serviam para levantar a questão da monogamia, que foi muito 
discutida e criticada, sendo também taxada de "machista". A exclusividade sexual era vista como mais uma ideia que os novos traziam para o grupo e que tinha de ser combatida pelos "mais conscientizados", especialmente os do grupo de atuação.

Ao contrário da esperada recuperação do sentimento de fraternidade grupal, essa viagem serviu para deixar mais claras as desavenças dentro do Somos. O "subgrupo problema" ficou mais marginalizado ainda e alguns dos líderes do subgrupo de atuação foram atacados, como o próprio Raimundo, fundador do Somos e influente líder informal, que foi acusado de se comportar como "uma rainha destronada".

Também em relação às mulheres, nada foi conseguido: as chamadas "feministas radicais", isto é, aquelas que vinham acusando os homens de serem "machistas" e que exigiam um subgrupo exclusivamente lésbico, não compareceram. As que haviam ido eram, compreensivelmente, aquelas que admitiam a possibilidade de uma convivência frutífera ao lado dos homens e que tinham uma certa suspeita do termo "machismo". Consideravam esse termo demasiadamente amplo, além de ser uma expressão até então usada quase exclusivamente pelas "radicais". Porém, não tardaram a adotar esse termo, elas mesmas, contra as suas adversárias.

Assim, apesar da ausência das mulheres mais críticas, esse feriado marcou a adesão definitiva, por parte do subgrupo de atuação, ao termo "machismo". Até então, era um conceito mais usado por algumas mulheres, para agredir os homens, embora, às vezes, também, fosse usado contra as mulheres. Depois, começou a ser usado também pela "cúpula" masculina, contra outros homens. Nesse momento, foi muito comentada a falta que faziam as "feministas radicais", dizendo-se que elas teriam forçado uma maior discussão do assunto.

Havia fortes laços de simpatia e amizade entre os que eram vistos como "fundadores" da "cúpula" dos homens e as "feministas radicais", também acusadas de quererem formar uma "cúpula" das mulheres. Desde o início da campanha das feministas contra o "machismo" do grupo, elas haviam contado com o apoio de influentes membros do subgrupo de atuação. Estes agora se sentiram um pouco abandonados pelas suas antigas companheiras, que seriam as mais indicadas para legitimar o uso da expressão "machismo" contra seus opositores. De 
qualquer forma, o termo ficou definitivamente incorporado ao arsenal de acusações do grupo e, depois de certo tempo, quando outros aprenderam a empregá-lo, deixou de ser exclusividade das "cúpulas" masculina e feminina. A expressão adquiriu então um sentido mais amplo, sinônimo de autoritarismo, e não tardou a ser empregada contra seus introdutores originais. Logo algumas atitudes do subgrupo de atuação, que desagradavam outros integrantes do Somos, também começaram a ser chamadas de "machistas". A partir de então, todos concordaram em achar que seria esse o grande mal que atrapalhava o grupo, embora o sentido atribuído ao termo variasse de acordo com as pessoas e a ocasião.

De volta a São Paulo, o sentimento de mal estar do grupo continuava, talvez até mais exacerbado. Com o fracasso do "subgrupo problema", começou-se a colocar em questão até a ligação afetiva, considerada fundamental entre os integrantes do Somos. Tornava-se evidente que o "processo de identificação" era de natureza não somente finita como de curta duração. Significativamente, ele se esgotava mais rapidamente entre os novos membros, talvez porque os veteranos, dada a sua ascendência sobre o grupo, se sentiam mais estimulados por ele, do que os marginalizados recém-ingressos. A constatação do esvaziamento, ou mal funcionamento, dos subgrupos de identificação pôs em cheque também a posição do subgrupo de atuação, que os via como base de apoio e legitimidade para intervir na sociedade. Eram eles que davam ao Somos uma importância numérica e o "processo de identificação" era o que legitimava a ideia de um consenso grupal, atingido através das discussões informais de identificação e posto em prática pelo subgrupo de atuação. As divergências expressas pelas mulheres e pelos subgrupos forçaram a "cúpula" a encarar mais abertamente a questão de sua liderança. Numa reunião de atuação, em que se discutiu o assunto, esses indivíduos se caracterizaram como guardiões autoproclamados dos valores básicos do grupo, acima das reuniões gerais, consideradas por eles como "oscilantes" demais. Significativamente, durante essa reunião de atuação, foi proposto que este grupo também devesse ser fechado, para evitar a entrada demasiada de homens e de "novos" que o tornasse incapaz de funcionar - ou seja, que contestariam as posições "antimachistas" da "cúpula dominante"). 
A grande ameaça percebida eram os "novos", que logo dominaram o grupo numericamente. Este fenômeno foi chamado pejorativamente de "inchaço" e o grupo foi declarado "em crise".

\section{O apoio do Somos ao Lampião}

Outros focos importantes de atrito foram o relacionamento do Somos com o jornal Lampião e as medidas que grupo deveria tomar em seu apoio, quando este começou a sofrer ataques do governo. Mais uma vez, ficava evidenciada a heterogeneidade da composição do Somos, em particular, e do mundo homossexual, como um todo.

Já em agosto de 1978, os editores do jornal haviam sido informados que o Departamento de Polícia Federal do RJ decidira abrir um inquérito, com vistas a enquadrar a publicação, junto com seus responsáveis, no decreto 1077, da Lei de Imprensa, que tratava de ofensas à moral e ao pudor público. ${ }^{2}$ Este item da lei já fora usado contra o jornalista Celso Curi, responsável pela coluna gay do jornal paulista Última Hora e contra um poeta de Brasília, Nicolas Behr, mas ambos conseguiram absolvição. Ainda pendiam inquéritos contra a revista Interview, que publicou entrevistas consideradas atentatórias à moral e bons costumes, com Ney Matogrosso, Bety Faria ${ }^{3}$ e Yonita Salles Pinto; ${ }^{4}$ e com Isto $E^{5}$, que também havia dedicado várias de suas páginas, além de sua capa, a um longo artigo sobre homossexualidade. Dizia-se que o inquérito teria o respaldo do próprio Ministro da Justiça de então, Armando Falcão.

A absolvição de Celso Curi foi vista como altamente positiva para a defesa do Lampião. O jornal, que em seu número zero publicara extensa matéria sobre o processo contra Curi, se juntou ao Somos para divulgar um panfleto anunciando que esse havia sido o primeiro caso de denúncia à homossexualidade na Justiça Brasileira e que a sentença de absolvição seria um precedente benéfico para outras publicações

\footnotetext{
2 Inquérito, n. 25 - 78 do Departamento de Polícia Federal do Rio de Janeiro.

3 Interview, São Paulo, n. 5, maio 1978.

4 Interview, São Paulo, n.6, 8 jun.1978.

5 Isto É, São Paulo, n. 53, 28 dez. 1977.
} 
submetidas a inquéritos por razões similares. O documento terminava com a declaração de que essa absolvição havia redobrado "as forças de luta de todos os que defendem o livre arbítrio, a liberdade de imprensa e as liberdades democráticas neste país". As reivindicações dos homossexuais eram, assim, colocadas em pé de igualdade com as outras exigências que a sociedade civil estava fazendo ao governo. Essa seria a tônica principal da campanha daí para frente, conseguindo-se, desse modo, o apoio de personalidades e organizações, que normalmente relutariam em se comprometer com a causa homossexual.

Em abril de 1979, os membros do conselho editorial do jornal, residentes no Rio de Janeiro, Aguinaldo Silva, Francisco Bittencourt, António Chrysóstomo, Clóvis Marques e Adão Acosta tiveram que se apresentar no DPF, para serem fotografados e terem suas impressões digitais tomadas, além de prestarem depoimentos. Alguns meses depois, o mesmo ocorreu com os residentes em São Paulo: Darcy Penteado, João Silvério Trevisan, Jean-Claude Bernardet e Peter Fry. Em julho de 1979, foi enviada outra intimação ao jornal. Desta vez, era exigida a apresentação dos livros de contabilidade no DOPS do Rio de Janeiro. O advogado da ABI, Luis Celso Soares de Araújo, que estava representando o Lampião, considerou a solicitação ilegal, arbitrária e sem nenhuma relação ao inquérito em andamento. Acreditava-se que esse novo tipo de pressão, por parte das autoridades policiais, era inspirado em um documento secreto do Centro de Informações do Exército (CIE), que algum tempo antes havia sido levado ao público, pelo jornal O Estado de S. Paulo. Este documento recomendava medidas alternativas para controle da imprensa, uma vez abrandada a censura oficial. Uma das medidas preconizadas era a de promover devassas na contabilidade das editoras de jornais "nanicos", para levá-las a encerrarem suas atividades por razões fiscais. Pretendia-se provar que o Lampião não tinha condições de sobreviver como empresa.

$\mathrm{O}$ ataque ao jornal revestia-se de características que claramente ameaçavam toda a imprensa brasileira e, portanto, o Lampião pôde gozar de bastante solidariedade por parte de seus pares. O Sindicato dos Jornalistas Profissionais do Estado de São Paulo mandou um telegrama ao Presidente da República, pedindo que cessassem as perseguições aos jornais, citando nominalmente o caso do Lampião. Uma 
nota de protesto do Lampião foi publicada no Rio de Janeiro e em São Paulo, pelos jornais, O Globo, Tribuna da Imprensa, Última Hora, Folha de São Paulo e O Estado de São Paulo. Segundo Lampião, o Jornal do Brasil se omitiu, porque seus diretores tinham ordem expressa de ignorar qualquer reivindicação de homossexuais. ${ }^{6}$

Por sua parte, o jornal procurou revidar as suspeitas de sua falência, publicando um artigo explicando que, ao contrário dos Atallas, da Construtora Adolfo Lindenbergh e outros casos célebres de insolvência na época, Lampião não devia nada a ninguém. Afirmava-se que a editora não visava lucro, a verba da venda de um número sendo usada para pagar a edição do próximo, e que, até então, o jornal nunca se atrasara para chegar às bancas. ${ }^{7}$

Este novo desenvolvimento da perseguição ao Lampião levou alguns dos integrantes do Somos, especialmente aqueles mais comprometidos com o subgrupo de atuação, a tomarem atitudes de apoio ao jornal. O relacionamento entre o Somos e o Lampião tinha um componente simbiótico, pois, várias vezes, integrantes do grupo haviam saído às ruas divulgando o jornal em meios homossexuais, distribuindo cópias de números antigos que tivessem artigos sobre o Somos. Havia-se até feito um carimbo para marcar esses exemplares, com os dizeres “Cortesia Grupo Somos", seguidos do número da sua caixa postal.

Agora considerou-se necessário ir mais além e uma reunião foi convocada pelos interessados em apoiar o jornal. Esta reunião foi coordenada por Charlie, que lembrou aos presentes que, pouco tempo antes, a revista Versus, ligada à Convergência Socialista, também havia sofrido perseguições das autoridades e conseguira escapar graças a uma campanha de defesa, da qual ele participara e cujo know-how poderia transmitir ao Somos. Foi dito, também, que uma campanha de apoio ao Lampião poderia canalizar o desejo de mobilização, cada vez mais premente para os integrantes do subgrupo de identificação.

Sugeriu-se a criação de uma comissão de defesa do Lampião, que poderia, ou não, ser ligada nominalmente ao Somos e que poderia,

6 Lampião, p. 5, ago. 1979.

7 Lampião, p. 5, ago. 1979. 
também, incluir Darcy Penteado ou outros que se mostrassem interessados, mesmo não integrando o grupo. Charlie informou que já havia conversado com o líder da campanha do Versus e este recomendara a elaboração de um abaixo assinado restrito, por razões de tempo e logística, a personalidades políticas, artísticas e entidades democráticas como: ABI, CBA, sindicatos, etc. Durante essa reunião, foi argumentado que muitas dessas personalidades, com projeção na vida parlamentar ou artística, talvez relutassem em ver seus nomes associados à causa homossexual e que, portanto, seria melhor enfatizar a questão da liberdade de imprensa ao invés da questão sexual.

Apesar de ser inicialmente muito bem recebido, o auxílio proposto pela Convergência Socialista logo começaria a despertar as desconfianças dos outros fundadores do Somos e amigos seus. Alegando longa experiência política, alertavam para o perigo do "entrismo", que diziam ser praticado por grupos trotskistas, desejosos de tomar o controle de determinadas organizações populares.

A proposta de se organizar uma comissão de defesa e de circular um abaixo assinado parece ter sido completamente independente dos responsáveis pelo jornal, chamados desdenhosamente de As tias do Rio, por serem considerados mais velhos e mais "caretas". Alguns receavam que certas propostas mais radicais, como a pichação de muros, pudessem ter efeitos adversos. Mas nada parecia desaconselhar o abaixo-assinado e seus preparativos foram levados adiante.

Alguns dias depois, Charlie apresentou um texto para o documento a ser endereçado ao Ministério da Justiça. Este foi aprovado, mas a redação de um panfleto a ser distribuído nos meios homossexuais foi mais problemática e, apesar de uma comissão ser nomeada para reescrevê-lo, a partir de um esboço previamente elaborado pelo grupo, o resultado acabou sendo considerado "demasiadamente panfletário". Durante algum tempo, isso seria apresentado como nova tentativa de atrelamento do Somos à "luta geral".

Nessa ocasião, Charlie apresentou outra sugestão, inspirada nas práticas da imprensa partidária. Todo militante deveria se comprometer a vender dez exemplares de cada edição do Lampião. Isso causou nova polêmica, alguns diziam temer a repressão, outros não concordavam com a linha editorial do jornal, outros ainda diziam não desejar 
se assumir como homossexuais fora do Somos. Por fim, decidiu-se deixar a opção por vendagem do jornal a cargo de cada um, sem nenhum tipo de pressão grupal. Esta ideia não teve muito sucesso e o Somos vendeu poucos exemplares nessa ocasião. Vale aqui lembrar, porém, que as mulheres do grupo costumavam sair à região do gueto lésbico vendendo aqueles números que falavam delas. Mas, mais que uma forma de ajudar o jornal, esta atividade era encarada como maneira de aproximação com as lésbicas "não organizadas".

Outra questão controversa referia-se ao status da comissão de defesa do Lampião dentro do grupo, já que contaria com a participação de indivíduos, como Darcy Penteado, que não pertenciam ao Somos. Dentro do clima de crise do grupo e do questionamento da representatividade do subgrupo de atuação isso criava problemas. Por outro lado, o estado de desorganização, em que o Somos se encontrava, impossibilitava a tomada de decisões rápidas por consenso.

Estimulados pela iminência de fechamento do Lampião e pela ideia de que a participação na campanha fortaleceria o grupo, alguns militantes resolveram levar adiante o trabalho por conta própria. Charlie obteve do Versus uma lista de possíveis assinantes, e, a esta, Darcy Penteado acrescentou outra de artistas amigos seus.

Dentro do Somos, as diferenças tornavam-se cada vez mais claras e irreconciliáveis; incapaz, tanto de consenso, quanto de conviver com uma pluralidade de posições políticas, o grupo dava sinais de esfacelamento.

A comissão formada para lidar com a questão da defesa do jornal acabou servindo para aglutinar aqueles que tinham um interesse pela militância política mais tradicional. Pois, nesse caso, pretendia-se adotar as mesmas técnicas usadas pelos responsáveis pela revista Versus, pautados por um modelo organizacional leninista. O grande propulsor dessa comissão foi Charlie, que abrigava as reuniões em sua própria casa. Detentor de um certo know-how para esse tipo de atividade, devido a sua experiência de militância nos EUA, além de ser o principal contato do grupo com a revista Versus e a Convergência Socialista, ele foi escolhido coordenador e representante da comissão perante o Somos. Outros membros dessa comissão também faziam parte do subgrupo de atuação e, deste modo, 
ela ficou identificada, aos olhos do resto do grupo, como mais uma tentativa da "cúpula" de impor a sua autoridade sobre os subgrupos de identificação.

Um dos "velhos", como eram chamados os veteranos fundadores do Somos e os seus mais influentes integrantes, era, justamente, Charlie, que, segundo muitos, desejaria atrelar o Somos às posições trotskistas da Convergência Socialista. Como, além disso, a comissão passou a ser o único subgrupo do Somos a manter qualquer tipo de atividade não explicitamente voltada à solução da "crise" que o grupo estaria sofrendo, ela começou a polarizar as atenções e os sentimentos de agressão originalmente dirigidos diretamente ao subgrupo de atuação.

Começou-se a falar que Charlie pretendia radicalizar indevidamente o Somos e o texto do documento a ser distribuído no gueto foi muito criticado por seu suposto tom "panfletário" e "provocador".

O conselho editorial carioca do Lampião, representado por Antônio Chrysóstomo, de passagem por São Paulo, também considerou o seu teor provocativo e sugeriu que ele fosse submetido ao parecer de um advogado antes da sua distribuição. Isto ajudou a insuflar o medo de vários integrantes do Somos que passaram a criticar até a confecção de fotocópias para fins de discussão interna, receando que algumas, carregando o nome do grupo, "caíssem em mãos indevidas".

A maioria dos integrantes do Somos nunca tinha tido nenhuma experiência de organização política e compartilhava dos sentimentos, comuns na sociedade em geral, de total suspeita e cinismo a respeito da política tradicional. Somando-se isto ao temor da, ainda real, repressão policial exercida contra organizações da oposição, apresentava-se, assim, uma desculpa perfeita para muitos encerrarem sua participação no grupo, que já sentiam como frustrante e desgastante, por uma série de outras razões. Portanto, ao invés de funcionar como a solução para o problema da falta de objetivo concreto do Somos, o trabalho da comissão de defesa do Lampião tornou-se mais um ponto de atrito e Charlie começou a ser visto com grandes suspeitas por alguns, que chegaram a acusá-lo de pretender levar o grupo à dissolução. Polarizou a tal ponto o descontentamento geral, que a autoria 
do polêmico panfleto era comumente atribuída a ele, embora, na realidade, outros personagens, bem menos controvertidos, tivessem sido os responsáveis. Apesar de eu ter apontado esse paradoxo várias vezes, este dado não foi levado em consideração, reforçando minha opinião de que as críticas a Charlie se deviam, também, a outros fatores menos explicitados.

Devido ao intenso questionamento que os outros subgrupos faziam a respeito do "cupulismo" do subgrupo de atuação e, por extensão, da comissão de apoio ao Lampião, esta sentia-se tolhida para tomar decisões em nome do grupo. Como essas decisões eram necessárias, para levar em frente o trabalho proposto, os membros do subgrupo foram tomados por um forte sentimento de frustração.

O único momento em que se poderia tomar uma decisão deste tipo seria durante uma reunião geral, quando todos os participantes poderiam dar suas opiniões e manifestar sua aprovação ou não da ideia. Alguns dias depois, houve a esperada reunião, convocada não só para discutir a questão do panfleto, mas também para tentar resolver a crise interna pela qual passava o Somos. A discussão sobre o documento acabou tomando a maior parte do tempo da reunião, frustrando as expectativas daqueles que desejavam uma reestruturação do grupo. Resolveu-se que o panfleto, como fora apresentado, não era aceitável, mas que uma versão ligeiramente adaptada do texto do abaixo assinado, desde o início concebido como mais branda em sua linguagem, poderia ser distribuído entre frequentadores do gueto homossexual. Ironicamente, alguns viram isto como uma derrota sofrida por Charlie, quando, de fato, o texto que foi finalmente aceito havia sido escrito por ele, ao contrário do mais agressivo panfleto original.

Mas, apesar do tempo e da energia despendidos nesta discussão, que muitos consideraram quase fatal para o Somos, a panfletagem acabou não se consumando e o abaixo assinado deixou de ser entregue às autoridades. Afinal, em outubro, a Justiça resolveu arquivar o processo contra o Lampião, levando em conta o parecer do Procurador da República, Sérgio Ribeiro da Costa, a respeito do jornal. Parte desse parecer dizia: "No caso em exame, a publicação inquinada de ofender a moral pública pode ofender a moral de alguém, mas não de 
todos. Portanto, é relativo e não absoluto o conceito de moral daqueles que condenam essas publicações". ${ }^{8}$

Chegava ao fim uma série de pressões e vexames sofridos pelos responsáveis pelo jornal. Essas haviam incluído: visitas matinais de agentes do DPF, solicitações arbitrárias, como a de exigir livros contábeis, a humilhação de serem qualificados e identificados como criminosos numa repartição policial, etc. Dias antes, fora também arquivado um inquérito contra a revista Isto É, que publicara matéria de capa sobre homossexualidade, e houve quem atribuísse esta mudança de atitude à troca do Ministro da Justiça, pois saíra Armando Falcão e entrara Petrônio Portela, considerado mais liberal. Encerrado o episódio, em dezembro de 1979, Lampião publicou um artigo agradecendo a todos que o haviam apoiado. ${ }^{9}$

Neste relato das perseguições sofridas pelo Lampião, observa-se como era bem fundamentada a percepção dos integrantes do Somos sobre opressão generalizada sofrida pelos homossexuais. Além da ridicularização e do ostracismo sofrido por eles em nível individual e razão para uma mobilização de natureza defensiva e de apoio mútuo, persistiam sérios entraves a uma discussão positiva e bem informada sobre sua orientação sexual.

Como já foi mencionada, a perseguição policial não se restringia a um órgão da imprensa "nanica", como o Lampião, mas até uma revista “respeitável”, como a Isto É, e um jornalista escrevendo para a grande imprensa, como Celso Curi, chegaram a sofrer ataques, por terem ousado levantar uma discussão mais informada sobre o assunto. $\mathrm{O}$ próprio documento do CIE. mencionava nominalmente o Lampião, como um jornal a ser vigiado. A única forma oficialmente aceitável de abordar o assunto parecia ser aquela da imprensa sensacionalista, do tipo Notícias populares, ou deturpadora, como a Manchete.

Mas os ataques não vinham somente da direita. Os incidentes ocorridos durante a Semana da Convergência Socialista e as intervenções agressivas por parte de esquerdistas presentes aos debates na USP

8 Lampião, p. 2, nov. 1979

9 Lampião, p. 2, dez. 1979 
comprovam o quanto a questão era mal vista também por certos setores oposicionistas. A isto devemos também ajuntar os casos de alguns integrantes do Somos que contavam terem sido expulsos de grupos marxistas por causa de sua homossexualidade.

Se juntarmos a essas constatações a lembrança da repressão sistemática, que existiu até 1978, contra qualquer agrupamento contestatório, torna-se fácil entender a aparente timidez inicial dos integrantes do Somos que receavam se expor em público. Para muitos, os debates de fevereiro de 1979 foram sua primeira admissão pública de homossexualidade. Vários dos que participaram da mesa de trabalhos, no dia do debate sobre o assunto, relataram depois ter sentido muito receio, algumas vezes beirando o pânico. Até durante os inquéritos policiais sobre o Lampião a defesa achou prudente enfatizar ao máximo a categoria de "jornal das minorias", tentando minimizar o seu aspecto homossexual. Esta mesma estratégia, de se acobertar sob a maior "respeitabilidade" de outros grupos minoritários, tais como os negros ou as mulheres, também foi adotada ocasionalmente pelo Somos. Não foi mero acaso o fato do seu primeiro aparecimento em um ato público ter sido nas comemorações do Dia de Zumbi, de 1979, promovidas pelo Movimento Negro Unificado. Essa preocupação com "respeitabilidade" não era infundada. Sua importância pôde ser comprovada posteriormente, por ocasião dos protestos contra os ataques policiais às áreas centrais da cidade, quando nem a presença simbólica de representantes negros, feministas e estudantes foi suficiente para animar políticos e personalidades de destaque a participarem de uma passeata predominantemente formada por homossexuais e prostitutas.

Foi somente após se tornar conhecido, especialmente através de publicações de imprensa alternativa, que o Somos começou a sair em público e a ser aceito como mais um grupo político que reivindicava os seus direitos de cidadania.

\section{O Somos tenta resolver sua "crise"}

Nas semanas que seguiram o feriado de Corpus Christi, a situação do grupo parecia piorar. Tornava-se evidente a falta de consenso dentro do grupo e o sentimento de afeto entre os seus membros era 
percebido como enfraquecido. Foi iniciada a campanha em apoio ao Lampião, com todos os receios e desavenças já narrados, e acirravam-se os desentendimentos entre os homens e as mulheres do grupo. $\mathrm{O}$ resultado das críticas que elas faziam pareciam apontar para a saída definitiva de muitas mulheres do Somos, pois poucas estavam dispostas a permanecer no subgrupo lésbico feminista, que havia tomado para si o espaço feminino do grupo. Embora, por ser homem, eu não tenha podido acompanhar muito de perto os acontecimentos entre as mulheres, dispondo, portanto, de poucos dados, não pude deixar de notar uma crescente desavença entre elas, com as chamadas "feministas radicais" sendo acusadas de querer formar uma "cúpula de mulheres". Ilustrativa dessa tendência, foi uma das exigências que elas fizeram em uma reunião geral, pouco antes do feriado de Corpus Christi, em que propuseram que só poderiam falar pelas mulheres aquelas que pertencessem aos subgrupos exclusivamente femininos. As outras dos grupos mistos, consideradas como de "pouca consciência da condição específica da mulher”, só poderiam falar pelos homossexuais. Porém, diante dos veementes protestos, por parte de várias que se sentiam bem integradas com os homens, esta exigência teve de ser abandonada. Mas, começara um êxodo das mulheres do Somos e, mesmo dentro do subgrupo lésbico, só restavam quatro integrantes "convictas", embora várias outras comparecessem a algumas reuniões para, depois de certo tempo, desaparecerem.

Outro sinal preocupante foi a progressiva deterioração das festas organizadas pelo Somos. Concebidas, originalmente, como ocasiões em que as pessoas poderiam se encontrar em situações mais informais do que nas reuniões para se "paquerarem" e "transar seu afeto", algumas destas festas, realizadas no Studio Twenty-Four, uma discoteca gay, na Rua das Palmeiras, $n^{\circ} 240$, acabaram perdendo seu aspecto de festas do grupo, tornando-se meros encontros de alguns integrantes do Somos, dentro de uma discoteca onde a maioria dos frequentadores eram homossexuais "não organizados", os seus clientes usuais. Nessas condições, elas também logo começaram a perder sua atração para os membros do Somos.

Reinava um mal estar generalizado. Até integrantes fundadores do Somos, assíduos nas reuniões de atuação, começaram a se queixar da 
excessiva politização do grupo, revelada pela proposta do panfleto de apoio ao Lampião. Alguns criticavam, também, um certo radicalismo anti-heterossexual, manifestado na forma profundamente desconfiada com que eram discutidos possíveis apoios a serem dados por não homossexuais ou como eram encaradas as entrevistas solicitadas por qualquer publicação que não fosse o Lampião. Nessa época, também se começou a falar de roubos e estragos ocorridos durante reuniões do grupo nas poucas casas ou apartamentos onde isso era viável. Como consequência, diminuíram os locais disponíveis tornando necessária a reabertura das discussões sobre como conseguir uma sede para o Somos. Esse era sempre um assunto frustrante, dada a dificuldade sentida pelo grupo em se comprometer a pagar um aluguel mensal, justamente quando aparecia o risco de uma dissolução definitiva.

No dia 11 de agosto de 1979, houve uma reunião geral do Somos, realizada em uma sala disponibilizada pelos representantes estudantis da Faculdade de Ciências Sociais da USP. Havia-se pensado em fazer a reunião no Teatro Oficina, como da vez anterior, mas o relacionamento entre aquele grupo teatral e o Somos se azedara por vários motivos que tinham por base as posturas intransigentes dos militantes homossexuais e a sua inabilidade em conviver com pontos de vistas ligeiramente diferentes.

Os problemas entre os dois grupos haviam começado quando, em uma ocasião anterior, o Somos pediu emprestado o palco do Teatro Oficina para realizar uma reunião geral. Seguindo uma orientação de ceder os seus espaços para outras manifestações políticas e culturais, o Oficina havia aberto suas portas à organização homossexual. Além de ter uma proposta sexual libertária, aquele grupo contava com vários atores de orientação homossexual e na hora da reunião, alguns pediram para assisti-la. Porém, alegando que essa seria uma reunião exclusiva para os membros do Somos, alguns militantes expulsaram do recinto os membros do Oficina.

Desejando manter um diálogo entre os dois grupos representantes do Oficina, convidaram o Somos a assistir um dos seus espetáculos para depois realizar um debate a respeito. Porém, integrantes influentes do Somos comentaram que o espetáculo, ao propor uma liberdade sexual generalizada, parecia mais interessado no bissexualismo 
do que na homossexualidade. Esse era um velho tema de discussões no Somos, no qual os membros da classe teatral costumavam ser acusados de "enrustir" sua homossexualidade atrás de uma suposta bissexualidade. Como grande parte dos integrantes do grupo não tinha muito interesse pelo teatro e como alguns dos líderes de opinião do grupo criticavam severamente as ideias do Oficina, a maioria das integrantes do Somos não compareceu na data marcada para a reunião teatral.

No mês seguinte, impulsionada pela dificuldade de encontrar espaços suficientemente amplos para a realização de reuniões gerais do Somos, uma comissão do grupo voltou a pedir emprestado o palco do Oficina. Desta vez, foi-lhes novamente oferecido o teatro, mas com condição de que assistissem ao espetáculo e ao filme $O$ parto, que José Celso Martinez Correa e outros membros da companhia haviam feito sobre a Revolução Portuguesa de 1974.

Isto causou grandes discussões dentro do Somos. Alguns lembraram que o Oficina costumava ser invadido pela polícia e estava sujeito a um tipo de repressão muito parecido ao que poderia ser desencadeado contra o Somos a qualquer hora e que, portanto, seria apropriado buscar algum tipo de aliança com eles. Outros tinham reservas a respeito da proposta, dizendo que o Oficina desejava simplesmente "fazer a cabeça" dos homossexuais. Outros ainda criticavam o espaço disponível no teatro, por ser demasiadamente grande e frio, o que dificultaria o contato mais íntimo entre os participantes da reunião. Essas objeções parecem, em retrospectiva, resumir alguns dos principais problemas do Somos: a sua inabilidade de conviver com pontos de vista divergentes e a ênfase absoluta no contato pessoal e íntimo entre seus integrantes, que inevitavelmente limitavam as possibilidades de expansão do grupo.

Alegando que não lhes era permitido tomar decisões do tipo proposto pelo Oficina, a comissão do Somos recusou a oferta condicionada do espaço e a reunião seguinte foi realizada na Cidade Universitária, local pouco conveniente, devido à sua distância do centro da cidade e do gueto homossexual.

Nessa reunião, o declínio do entusiasmo pelo grupo ficou mais uma vez patente no número relativamente reduzido de participantes 
-49 , incluindo 8 mulheres. Com o surgimento de conflitos internos mais sérios, as propostas "assembleistas" de organização mostravam-se insuficientes e desgastantes, permitindo a dominação inquestionável por parte de certos líderes informais, que monopolizavam grande parte do tempo disponível. Nessa reunião, esse processo se exacerbou. A maior parte do tempo foi tomada pela discussão de uma pauta de informes de pouco interesse geral, preparada anteriormente pelo subgrupo de identificação que, ignorando o limite de tempo preestabelecido para cada exposição e se aproveitando da vacilação e inexperiência do coordenador provisório escolhido para a reunião, ocupou mais de uma hora com sua exposição. Com o passar do tempo, a má vontade dos ouvintes foi crescendo e a reunião começou a se dissolver sem chegar a nenhuma conclusão. Nos últimos instantes, quando todos já começavam deixar o recinto, Charlie propôs que o subgrupo de atuação fosse substituído em suas atividades organizativas por um grupo de coordenadores escolhidos pelos vários subgrupos, para voltarem a se reunir em "território neutro", em outras palavras, em um apartamento onde a "cúpula" não pudesse exercer seu poder costumeiro.

Esta nova reunião aconteceu, de fato, na data marcada, mas não diferiu muito das reuniões normais do subgrupo de atuação. Quase todos os nove homens presentes, escolhidos como representantes, pertenciam àquele subgrupo e os coordenadores dos subgrupos mais problemáticos deixaram de comparecer. Vários membros da "cúpula" participaram dessa reunião, na condição de "interessados”, mesmo sem serem indicados para ir. Conseguiu-se, assim, a aprovação de uma proposta, previamente elaborada pelo subgrupo de atuação, para um novo encontro que se realizaria em algum lugar de São Paulo. Este deveria durar dois dias e, além de possibilitar uma maior discussão dos problemas do Somos, esperava-se que a convivência prolongada fomentasse o ressurgimento do velho espírito fraternal. Afinal, este, que era considerado por muitos como o aspecto mais importante do grupo estava claramente se esvaindo.

Incidentes que ocorreram numa reunião geral, realizada poucos dias depois, no salão de festas do prédio onde moravam dois integrantes do Somos, mostraram, porém, que nem mesmo a atuação de 
agentes percebidos como "inimigos externos" conseguiria mais ressuscitar o velho comunitas.

Nessa reunião, um grande número de participantes se mostrou disposto a discutir, durante quatro horas e meia, os problemas do grupo, chegando até a um acordo satisfatório sobre a questão do abaixo assinado de apoio ao Lampião. Em seguida, como previamente programado, o local de reunião foi arrumado para uma festa.

Carmem Cinira Macedo, em seu trabalho sobre as Comunidades Eclesiais de Base, enfatiza a importância de festas para a construção de uma imagem e a representação da visão ideal do grupo. Essas comemorações, segundo argumenta, servem para exprimir e afirmar valores, reforçando certos padrões ideais de conduta ao mesmo tempo em que são cerimônias rituais; um revivescimento e reafirmação expressiva de valores que regem aquela comunidade. (MACEDO, 1986, p. 186) Nesta ocasião, quando se estaria pretendendo resolver as várias crises do Somos, uma celebração desse tipo era considerada por todos como importante e um grupo de rapazes até preparou um espetáculo para apresentar. Embora nenhum deles externasse qualquer pretensão didática para a ocasião, um exame mais atento de seu roteiro revela facilmente como o "show de variedades" servia como reafirmação explícita dos valores do grupo, ao aludir a vários aspectos do universo de preocupação do Somos. Concebido no mesmo estilo daquele realizado durante o feriado de Corpus Christi, esse espetáculo traria de volta a personagem "Bixênia", revivida pelo seu criador original, como a apresentadora de um programa de televisão. Suas apresentações seriam ocasionalmente interrompidas por "comerciais", cantados e dançados pelas "bichetes" ou "fedidinhas". Apareceriam também quatro rapazes vestidos de travestis caricatos, uma "espanhola" dublaria um tango, "Bixênia" entrevistaria o político "Brichola", fundador do PTB (Partido de Todas as Bichas), haveria uma cena de fim de caso, parodiando uma peça famosa, um "desfile de modas femininas" e uma dança do ventre. O show deveria terminar com "Bixênia" denunciando um certo CCB (Comando de Caça às Bichas) e sendo arrastada do "estúdio" enquanto as "bichetes" interviriam fechando o programa, com um número musical. 
Fica evidente, nesse roteiro, o desejo de ridicularizar tanto o machismo da esquerda, representado pelo caudilho "Brichola", quanto o perigo da repressão direitista, por parte do CCB, já que um, obviamente, parodiava Leonel Brizola, enquanto outro aludia às memórias, ainda recentes, das atividades terroristas do Comando de Caça aos Comunistas. O aspecto "comercial" do programa pode ser entendido como um reflexo das discussões sobre o "consumismo de direita e de esquerda", promovidas por Trevisan e pelo Lampião, enquanto a discussão do "fim de caso" aludia aos debates sobre a vida dos militantes, que ocorriam durante as reuniões de identificação.

O clima satírico e o travestismo, em torno do qual se construíam vários números, reafirmavam a importância da "fechação", enquanto forma de questionamento e crítica social. Servia também para reafirmar a importância das ligações entre o Somos e o gueto homossexual, na procura de combater o "ranço elitista", percebido como uma eterna ameaça à militância homossexual. Finalmente, deve-se notar que a total ausência de mulheres nessa apresentação espelhava o crescente distanciamento entre os homens e as lésbicas, tanto na direção, quanto no dia a dia do grupo.

O desenvolvimento dessa festa também serviu para desvelar cruelmente a verdadeira estrutura de comando do Somos e os seus valores. Inicialmente, devido à conclusão, considerada "bastante satisfatória" das discussões da tarde, o clima parecia propício a uma festa divertida e até as mulheres compareceram em bom número. O antigo espírito de fraternidade e camaradagem dava indicações de se recuperar, até ocorrerem uma série de tumultos ocasionados pela chegada indesejada de um grande número de rapazes e moças, que estavam saindo de um espetáculo de música popular realizado no auditório da Fundação Getúlio Vargas, na vizinhança. De início, a invasão foi pouco notada até que um rapaz bêbado começou a incomodar os presentes, fazendo comentários considerados "machistas". Alguns dos integrantes da festa - em sua quase totalidade integrantes do subgrupo de atuação - tentaram tirá-lo à força, o que causou uma grande algazarra. Em pouco tempo, seguindo o exemplo dado por alguns dos "líderes" do Somos, os participantes da festa foram tomados de pânico e passaram a exigir que todos os penetras se retirassem. Nesse meio tempo, 
a moradora do edifício havia chamado a polícia e, com a colaboração de muitos do subgrupo de atuação, interrompeu a festa no meio do show, pedindo a todos que se retirassem antes da chegada da Rádio Patrulha. O desapontamento e a frustração foram gerais. O clima tornou-se ainda mais tenso devido ao fato dos rapazes que estavam travestidos para o show se sentirem muito ameaçados pela iminente vinda da polícia, pois receavam ser acusados de "atentado ao pudor".

Dessa forma, a já criticada dominação exercida pela "cúpula" ficou mais uma vez evidenciada e, dados os sentimentos de igualdade que eram especialmente fortalecidos nessas ocasiões festivas, foi percebida como exacerbadamente agressiva. Mais frustrante ainda foi a dificuldade encontrada em manter os ideais autonomistas do Somos perante o Estado e, especialmente, os seus agentes de repressão. Afinal, grande parte dos presentes haviam compartilhado do sentido de ameaça perante os "penetras heterossexuais", corroborando para que o chamado da odiada polícia, feito por uma das integrantes do grupo e moradora do prédio que temia a ocorrência de um quebra-quebra, encontrasse defensores, apesar da percepção geral de um possível desdobramento moralista e repressivo contra os próprios militantes.

Nesse momento, a tensão atingiu níveis altíssimos e, como uma forma de desabafo, alguns dos atores improvisaram um "espaço cênico" embaixo do viaduto na Praça 14 Bis, defronte ao prédio, onde apresentaram a programada cena de "fim de caso". Foi um comentário inconsciente, mas apropriado para a ocasião. Naquele clima de frustração e agressividade foi enterrada a antiga camaradagem e unidade do Somos. Para muitos, o "casamento com o grupo" acabou, definitivamente, naquela noite.

\section{O "Encontro"}

A partir de então, a atenção do grupo começou a ser voltada quase exclusivamente para a organização de um "Encontro", em que se uniriam discussões organizacionais e uma atividade mais lúdica, como um passeio conjunto, que ajudasse a reviver o espírito de sociabilidade dentro do grupo. Pouco depois da reunião geral, soube-se do arquivamento do processo contra o Lampião, e, a partir de 
então, o único assunto discutido era a crise do grupo e como resolvê-la. Foram feitas várias tentativas para achar um lugar barato, discreto e grande, adequado para o encontro. Tentou-se obter o uso de sítios, conventos e hotéis, mas tudo sem muito resultado. Nesse meio tempo, foram passando as semanas e o Somos parecia prestes a se esfacelar. O subgrupo lésbico passava por maus momentos, reunindo somente quatro mulheres. Perguntava-se se ele ainda existia. Quase todos os subgrupos de identificação deixaram de funcionar e as atividades alternativas propostas não conseguiam entusiasmar muitas pessoas. Tentou-se levar adiante um grupo artístico e até se cogitou em organizar um recital de poemas homossexuais. Outras formas de realizar as reuniões de identificação usando recursos psicoterapêuticos foram também experimentadas, mas tiveram pouco sucesso. Uma das realizações mais bem-sucedidas, nessa época, foi a feitura do Suruba, um jornalzinho interno do grupo, que seria aberto a todos os interessados e publicaria qualquer texto recebido, sem nenhuma espécie de censura.

Os únicos subgrupos que continuaram a se reunir regularmente eram os de atuação e a comissão de representantes. Mas estes tinham cada vez menos pessoas para representar e chegavam a convocar "representantes" de grupos, que, sabidamente, já não existiam mais, só para aumentar o número de interlocutores. No dia 19 de outubro, perante a constatação de que os dois grupos tinham quase a mesma composição, a comissão de representantes deixou de marcar reuniões, deixando a cargo do subgrupo de atuação a organização do encontro. Porém, esse subgrupo também estava indo mal e uma série de desavenças entre seus integrantes parecia prenunciar um fim iminente para o que sobrava do Somos.

Finalmente, perante a constatação de que o grupo não se aguentaria por muito mais tempo, resolveu-se promover o encontro na USP, deixando-se a ideia de um passeio conjunto para uma outra ocasião. Nos dias 27 e 28 de outubro, reuniram-se, no prédio da Faculdade de Filosofia da USP, vinte e três militantes do Somos, um número muito inferior aos oitenta em que se pensava originalmente. A grande maioria era frequentadores das reuniões do subgrupo de atuação e entre eles só haviam duas mulheres, que insistiam em não serem 
consideradas representantes do subgrupo lésbico - já então chamado LF - Lésbico Feminista. Mesmo estas, não pouparam críticas ao grupo, alegando que não só as suas reuniões, mas também seus próprios integrantes, eram "chatos", "autoritários" e "machistas".

Grande parte do tempo foi dedicado à discussão de duas propostas antagônicas. A maioria dos presentes favorecia uma simples divisão do subgrupo de atuação para a realização de tarefas predeterminadas. Esses novos subgrupos funcionariam ao lado do subgrupo de identificação e cada um enviaria representantes para uma comissão encarregada de coordenar o grupo como um todo. Para evitar o surgimento de novas "cúpulas", recorria-se, mais uma vez, ao já desacreditado método de rodízio de coordenadores.

Contra essa proposta surgia outra minoritária que argumentava que o Somos deveria desistir de suas pretensões de crescimento constante. Ao invés disso, defendia-se que ele se limitasse a articular e a ajudar na formação de novos grupos homossexuais autônomos, com os quais pudesse estabelecer relações eventuais de colaboração. Esta segunda proposta foi quase unanimemente rechaçada. Mesmo aqueles "anarquistas", que mais reclamavam da "luta pelo poder", não concordaram com a proposta, chamando-a de "suicida". Charlie e os de visão marxista se colocaram claramente contra esta fragmentação proposital, lembrando da necessidade de força numérica e organização, para se poder fazer exigências em nome dos homossexuais.

Finalmente, premidos pela aproximação da hora de abandonar o recinto, os participantes concordaram com uma nova reestruturação dos subgrupos, seguindo de perto a primeira proposta. Os subgrupos de identificação foram rebatizados como "de reconhecimento", um termo considerado menos homogeneizador, e o subgrupo de atuação fracionou-se, criando novas comissões com tarefas específicas.

Coincidentemente, nesse fim de semana, a USP também era palco de uma manifestação estudantil pela retomada do seu Conjunto Residencial, fechado, em 1968, pelas autoridades militares. Um acampamento estudantil havia sido erguido nos gramados da universidade, próximo ao local em que o Somos realizou um piquenique durante um dos dias do Encontro, sem que houvesse nenhum tipo de confraternização entre os dois grupos de militantes. Apesar dessa falta de 
comunicação, não deixava de ser significativa a existência de outros movimentos simultaneamente ao Somos. Estes eram, muitas vezes, dirigidos a necessidades mais cotidianas, ligadas ao que os anglo-saxões chamam de life style, que à luta de classes propriamente dita. Questões relacionadas à vida cotidiana e aos costumes ganhavam grande destaque, alcançando status de "política", e o país parecia tomado por uma onda de liberalismo nesse campo. Durante o verão, por exemplo, sem nenhuma pressão popular que reivindicasse isso, as autoridades das grandes cidades litorâneas, como Rio de Janeiro e Salvador, anunciaram que, a partir de então, seria permitido às mulheres tomarem banho de sol com os seios descobertos. Também nesse ano, durante a viagem para Salvador onde participariam do $\mathrm{XXXI}^{\circ}$ Congresso da UNE, que pela primeira vez ocorria abertamente, depois de anos de clandestinidade, um grupo de estudantes paulistas concebeu a ideia de lançar um movimento de liberação sexual. Este nunca foi muito adiante, mas o fato de se ter cogitado a seu respeito é indício que não eram só os homossexuais que se preocupavam com o assunto. Nesse ano, foi realizado também o ${ }^{\circ}$ Congresso da Mulher Paulista e os grupos feministas começaram a alcançar melhor as mulheres das classes populares, ao lutar pela abertura de mais creches. Nesse clima, as reivindicações do Somos rapidamente ganharam espaço nos meios de comunicação, encontrando um público muito receptivo. Assim, apesar de suas "crises", o grupo continuou a atrair um considerável número de novos membros.

Nesta ocasião foi publicada também a lista de signatários do abaixo-assinado, reproduzida abaixo:

Clarice Herzog - Plínio Marcos - Luis Gonzaga Jr. - Alberto Guzik - Ivan Lins - Flávio Aguiar - Leyla Perrone Moisés - João Alexandre Barbosa - Antônio Cândido de Mello e Souza - Alfredo Bozi - David Arrigucci Jr. - Walnice Nogueira Galvão - Tereza Pires Vara - Paul Singer - Heloisa Fernandes - Maria Silvia Franco - José Arthur Gianotti - José Alvaro Moisés - Ruth Corrêa Cardoso - Fernando Herinque Cardoso - Luiz Roberto Cardoso de Oliveira - Yara de Homoway - Lúcio Kowarick - Maria Teresa Sadek - Leôncio Martins Rodrigues - Eunice R. Durham - Maria Lúcia Montes - M. Manoela Carneiro da Cunha - José A. Guilhon de Albuquerque - Octávio lanni - Francisco C. Weffort - José 
de Souza Martins - Cândido Procópio F. Camargo - Vinícius C. Brant Gabriel Cohn - Nicete Bruno - Paulo Goulart - Paulo Kein - Fernando Torres - Fernanda Montenegro - David José - Ester Góes - Nilda Maria - José Celso Martinez Correa - Cacilda Lanuza - Juliana Carneiro da Cunha - Sônia Mota - Tato Fischer - Roberto Piva - Altair Lima - Júlio Vilan - Paulo Villaça - Dercy Gonçalves - Bruna Lombardi - Carlos Alberto Ricelli - Fauzi Arap - Pedro Si Agnero - Fernando Peixoto - Ruth Escobar - Juan Oviedo - Luiz H. Galante - Antonio Maschio - Assunta Perez - João José Pompeu - Rafael de Carvalho - Consuelo Leandro Ismael Ivo - Raúl Raschou - Ruth Raschou - Marilena Ansaldi - Leilah Assunção - Ruthinéa de Moraes - Yolanda Cardoso - José Roberto Freitas - Sônia Loureiro - Imara Reis - Denise del Vecchio - Cláudia Mello - Eugênia de Domênico - Roberto Farina - Irene Ravache - Jacob Klintowitz - Renina Katz - Carlos Ricardo da Silva - Jornal Em Tempo - Jornal Convergência Socialista - Mário Sérgio Conti - Raimundo Rodrigues Pereira - Jornal Versus - Hélio Goldsztejn - Sindicato dos Jornalistas de São Paulo - APEOESP - AGRAF - Júlio Tavares - João Adão de Oliveira - Amílton Monteiro - Fernando Morais - Sérgio Santos - João Batista Breda - Franco Baruselli - Mauro Brosato - Eduardo Matarazzo Suplicy - André Bonassi - Rubens Larz Geraldo Siqueira Filho - Aírton Soares - Wanderley Macris - Almir Pazzianotto Pinto - Goro Hama - Marcos Aurélio Ribeiro - Mareia Porto Pimentel - Maria Cristina de Azevedo Róseo - Maria Aparecida Pinto Silva - José Augusto de Carvalho Junior - Isabel Blemel - Rita de Cássia Vilares - Rodolfo Bontuni - Antônio Carlos Pimentel - Clívio Tavares de Araújo - Celso Nunes - Regina Braga - Maria Bonomi - Cláudio Abramo - Radha Abramo.

Desta lista deixaram de constar um grande número de assinantes de igual expressão social, cujas assinaturas foram arrecadadas de maneira ilegível em uma reunião acadêmica da Unicamp. 


\section{Diferenças irreconciliáveis entre os "iguais"}

Exemplos de um novo tipo de mobilização popular, os movimentos sociais são muitas vezes apresentados de maneira demasiadamente idealizada. O seu suposto caráter espontâneo e democrático tem sido especialmente ressaltado e valorizado. Porém, pesquisas mais cuidadosas têm demonstrado que por trás dessas organizações ser comum se encontrarem indivíduos ou grupos ideologicamente motivados, nem sempre originários dos setores mobilizados. Estes impõem o seu próprio discurso ideológico sobre o movimento e se assenhoram de sua liderança. São geralmente pessoas cuja concepção de vida, religiosa ou laica, os leva a questionar a ordem social vigente. Procurando algum modo de atuar na sociedade, passam a organizar movimentos, com os quais costumam ter uma vinculação puramente circunstancial. Embora seja norma se engajarem em algo com o qual tenham um mínimo de relação - por exemplo: são mulheres que organizam movimentos feministas e negros que organizam movimentos contra a discriminação racial -, essas pessoas ideologicamente motivadas tanto podem se engajar em um movimento quanto em outro e geralmente são organizadoras de mais de um. (SINGER, 1983, p. 225) 
É uma característica comum desses movimentos a existência de uma notável distinção entre os "organizadores", portadores de uma série de ideias já elaboradas a respeito da sua atuação social, e as "bases", que são propelidas por uma motivação muito mais imediatista, específica e temporária. Outras diferenças importantes também são comuns, ocorrendo em termos de nível educacional, status social e disponibilidade de tempo para militância. Mas, uma das principais características desses movimentos é também a ênfase dada à igualdade de todos os seus participantes perante uma carência coletiva. Essa igualdade na carência é, então, percebida como obliterando todas as outras heterogeneidades.

Costumeiramente, manifesta-se o ideal de transmitir a motivação dos organizadores às bases, mas, na maior parte dos casos, somente um número limitado de membros da organização é alcançada dessa forma. Enquanto estes são capacitados para ascender da base para posições de liderança, o restante fica onde estava. (SINGER, 1983, p. 225) Mas, nem sempre é proposital ou consciente a manutenção dessa distinção entre os organizadores e as bases. Sabe-se, afinal, que a ideia da igualdade dos participantes é geralmente um dos cânones máximos desse tipo de movimento, em volta da qual se cria um sentimento de comunidade, unindo todos os seus participantes.

Eunice Durham nos chama a atenção para outro aspecto desses movimentos. Lembra que essa vivência da comunidade, da coletividade de iguais, criada pela ação conjunta, se dá numa dimensão própria, que implica uma novidade muito importante: o reconhecimento da pessoa num plano público e não privado. Essa experiência seria muito marcante para os participantes desses movimentos, que a percebem como um enriquecimento pessoal, uma intensificação de sua qualidade de sujeito. No movimento, as pessoas se conhecem, ampliam a sua sociabilidade e aprendem a encarar de forma nova as suas vidas, tornando coletivas e dessa forma integrando as experiências antes concebidas como individuais e fragmentadas. (DURHAM, 1984, p. 28)

Vemos, portanto, uma série de similaridades entre esse espírito comunitário e o já referido conceito de comunitas desenvolvido por Turner. Mas, da mesma forma, como esse é inevitavelmente ameaçado pela estrutura, a comunidade dos iguais deve manter uma 
permanente vigilância contra o surgimento da heterogeneidade em seu seio. Singer atribui a isso o fenômeno de "basismo", a constante reiteração da necessidade de "ouvir" as bases, às quais caberia sempre tomar as decisões. Mas, para ele, na maioria das vezes, tanto o "basismo", quanto a rejeição dogmática dos “de fora”, ajudam pouco a superar a distância entre a "cúpula" e as bases, sendo apenas armas nas lutas de facções entre os próprios organizadores. (SINGER, 1983) Afinal, são comuns as disputas entre lideranças e não é raro o caso de desavenças pessoais entre líderes adquirir uma coloração ideológica mais abrangente, se estendendo ao movimento como um todo. Nesse processo, as diferenças ocultas não desaparecem, mas passam para o espaço informal das fofocas, das acusações pessoais, das manipulações conscientes e inconscientes que caracterizam a prática desses movimentos quanto à vivência da união com a qual coexistem. (DURHAM, 1984, p. 30)

O desejo de evitar o aparecimento da heterogeneidade, em seu seio, leva esses movimentos a se declararem firmemente "apartidários”. A justificativa, normalmente oferecida nesses casos, é de evitar a manipulação dos movimentos para fins políticos definidos fora dele e não por ele. Mas, tanto as necessidades intrínsecas à atuação política na sociedade, quanto às já referidas convicções ideológicas dos "organizadores" tendem a estabelecer para esses movimentos conexões partidárias que, devido à sua natureza clandestina, são, então, pejorativamente classificadas como "clientelismo" - se com a direita -, ou "infiltração militante" - se com a esquerda. Entretanto, essas infiltrações e manipulações são partes integrantes do processo de mobilização e são importantes no estabelecimento de elos entre mobilizações restritas, centradas no interesse de alguns, com forças sociais e políticas mais universalizantes, presentes no conjunto da sociedade. (DURHAM, 1984, p. 30)

\section{Mudanças na composição da cúpula}

A história do Somos mostra muitos exemplos desses processos, a começar pela formação de uma cúpula dirigente com motivações ideológicas diversas. Durante o ano de 1974, dois dos principais 
organizadores do grupo podem ser considerados: Trevisan e Charlie. Eles não estavam sós na "cúpula", mas foram os principais expoentes de duas concepções antagônicas, que conseguiram muito apoio dentro do grupo, no qual se digladiaram durante vários meses. Ambos tinham demonstrado, anteriormente, a sua propensão a ingressarem em organizações de forte componente ideológico.

Trevisan, além de seminarista católico, havia sido militante de organizações esquerdistas. Ao se desiludir com elas, passou alguns meses morando na Califórnia, onde travou contato com a contracultura americana e com o movimento de libertação gay, que passava, então, por sua fase mais eufórica. Ao regressar ao Brasil, depois de muitas andanças pelo mundo, procurou diversas vezes começar nele um grupo de militância homossexual, entendendo que assim encontraria os parceiros e amizades que não achava em outras partes. Em 1978, começou a ter sucesso, participando da fundação do Núcleo de Ação pelos Direitos dos Homossexuais e do conselho diretor do Lampião. Durante muito tempo, sua relação com ambas as organizações foi intensamente emocional. Além de ter ligações de muito afeto com alguns dos militantes do Somos, exercia uma grande influência sobre o público leitor do jornal, escrevendo artigos em que defendia, com uma linguagem exaltada, a primazia do indivíduo contra qualquer tipo de massificação, quer inspirada por ideologias de direita ou de esquerda.

Charlie, também, tinha um passado de militância marxista, mas, ao contrário de Trevisan, nunca se "desiludiu" com ela. Militante trotskista de longa data nos Estados Unidos, lá, também havia participado de um grupo gay esquerdista. Chegando ao Brasil, logo se engajou na Convergência Socialista, vindo a ocupar uma posição de certo destaque na sua hierarquia. Sua vida parecia ser inteiramente voltada à militância e, apesar de inscrito em um curso de pós-graduação na Universidade de São Paulo (USP), dava pouca prioridade aos estudos em si. Mesmo sua vida social parecia ser completamente norteada pelos interesses da sua militância política, levando alguns de seus opositores a duvidarem da sinceridade de sua amizade e até a acusarem-no de fazer "política de cama". 
Apesar de Trevisan ter adotado uma visão política que, a grosso modo, se poderia chamar de "individualismo anarquista", durante certo tempo, ele e Charlie foram excelentes amigos, colaborando em harmonia para a criação do Somos, entre 1978 e 1979. Devido às suas experiências americanas, ambos tinham muitas ideias em comum a respeito de como deveria ser um grupo de militância homossexual. Eram também simpatizantes do feminismo, na época ainda pouco conhecido no Brasil, e pareciam concordar sobre a necessidade de autonomia para os movimentos de minorias. Desde o início do grupo, porém, havia algumas divergências entre eles, a respeito das principais funções do coletivo. Trevisan enfatizava o aspecto afetivo, de realização pessoal e de desenvolvimento de uma "consciência homossexual", enquanto Charlie priorizava o ativismo mais claramente político, interessando-se muito na criação de alianças com outros movimentos e na tomada de posições em relação à questão da chamada "luta geral". Foi um dos primeiros a propor a formação de um subgrupo de atuação, no qual essas questões pudessem ser discutidas.

Inicialmente, mesmo as divergências mais sérias entre eles, nunca afloravam em público, e suas posições só começaram a se definir como claramente antagônicas depois da já narrada reestruturação do grupo ocorrida no final de outubro de 1979.

Apesar do Somos ter perdido a sua comunitas, a nova estrutura concebida para o grupo funcionou adequadamente durante alguns meses. Uma das principais causas da "crise", pela qual havia passado, tinha sido diagnosticada como a liderança excessiva exercida pela "cúpula”, formada por alguns dos seus fundadores e outros que compartilhavam das mesmas ideias. A solução encontrada visava esvaziar o grupo de atuação do seu excesso de tarefas e poderes. Novos subgrupos foram formados para realizar tarefas específicas. Como se esperava, estes subgrupos permitiram uma maior participação

1 Trevisan certamente rejeitaria esse rótulo, assim, como qualquer outro, por ser demasiadamente restrito. Ele só é adotado aqui para designar, de forma sucinta, uma visão de mundo altamente questionadora e inconformada, tanto com as opções à direita, quanto à esquerda, todas elas concebidas como aniquiladoras da individualidade. 
dos membros novos, que continuavam a ingressar no grupo em números razoáveis, constituindo vários subgrupos de reconhecimento. Ao mesmo tempo, o desgaste produzido pela "crise" e pela perda de interesse depois de meses de atuação, levou vários dos veteranos a saírem do grupo ou, então, como Trevisan, a restringir drasticamente a sua atuação. Esta época também coincidiu com uma grave crise do grupo lésbico, cujos números desceram para quatro. Em suas reuniões ficava patente a perplexidade decorrente de uma total falta de noção a respeito dos seus objetivos e formas de atuação.

O resultado disto foi que, depois de dois meses de funcionamento, relativamente harmonioso, os integrantes realmente ativos no Somos eram outros. O subgrupo de coordenação havia sido imaginado originalmente como tendo uma composição rotativa e de mês em mês seus integrantes deveriam se revezar. Mas, por uma série de razões de ordem prática, essa ideia nunca se materializou e a coordenação foi feita por um grupo mais ou menos estável, dos "mais interessados" que, com exceção de Charlie, faziam parte de uma geração intermediária entre os veteranos e os ingressos depois da "crise".

A segunda metade de 1979 também contou com uma maior publicidade dada ao movimento homossexual, especialmente nos jornais da imprensa alternativa. Talvez, como consequência disto, ou como reflexo da crescente politização da sociedade, entre os que começaram a entrar para o Somos, havia uma proporção considerável já influenciada por, ou até engajada, em grupos de esquerda. Com a entrada destes e o retraimento dos veteranos que eram os principais formuladores da visão de mundo que se poderia chamar de "anarquista", dominante até então, começou uma mudança na orientação do grupo que, aos poucos, se tomou mais clara.

Um dos primeiros reflexos dessa alteração se deu com a participação do grupo nas comemorações do Dia de Zumbi, em 20 de novembro de 1979. Organizado pelo Movimento Unificado, esse ato público, em frente ao Mappin, no centro de São Paulo, era destinado a ser uma manifestação negra contra o racismo. Charlie e outros já falavam, há algum tempo, da importância de se estabelecer uma aliança com o Movimento Negro, cuja luta por uma identidade própria, por um fim 
à discriminação e contra a repressão policial, teria vários pontos em comum com a dos homossexuais. Esse parecia ser o momento certo para estabelecer contato.

Avisados dos planos para o ato público, o grupo de atuação externa e voluntários de outros subgrupos resolveram comparecer ao local. A ideia entusiasmou muita gente e entre vinte a trinta integrantes do Somos se propuseram a ir, incluídos aí alguns dos opositores de qualquer engajamento em uma "luta geral". Os negros eram vistos como outro grupo minoritário, lutando por suas especificidades e, portanto, dignos de todo apoio. Até mesmo o fato da Convergência Socialista oferecer a sua sede para a confecção de faixas não causou maiores questionamentos, assim como o fato da ideia de participar do ato ter partido de Charlie.

Esse dia marcou a primeira aparição em público dos militantes do Somos, que portavam faixas levando o nome do grupo e repudiando o racismo. Durante o ato, foi também distribuído um panfleto enfatizando que tanto os negros quanto os homossexuais eram "setores oprimidos".

Ao final do ato público, houve uma passeata até a Praça da Sé, e os militantes homossexuais, congregados embaixo de suas faixas, desfilaram abraçados, homem com homem, mulher com mulher, e, para o espanto divertido dos manifestantes negros e das pessoas que se encontravam nas ruas, "fechavam" exageradamente. Para os membros do grupo, esta pareceu ser a primeira passeata homossexual, apesar das palavras de ordem se referirem exclusivamente à condição negra. Reinava um clima de grande euforia entre os integrantes do Somos, felizes e ligeiramente surpresos com o sucesso de sua participação na passeata. Até então, sempre tinham receado sair abertamente em público, com medo de ataques, não só da polícia, mas do próprio povo nas ruas. Agora constatavam que não só o regime se tornara menos agressivo, mas que os próprios heterossexuais eram mais tolerantes do que haviam imaginado.

A política de "alianças", defendida por Charlie e até então só aplicada em relação ao Lampião, se mostrava uma ótima ideia. Nessa ocasião, além do apoio explícito dado ao Movimento Negro Unificado, o Somos havia também se aproximado da Convergência Socialista cujos membros se mostraram muito simpáticos, emprestando a sua 
sede para a confecção de faixas e oferecendo também outros tipos de auxílio. Charlie explicou várias vezes, nessa ocasião, que a Convergência Socialista fazia isso porque era parte de seu programa político dar apoio às lutas dos vários setores oprimidos da sociedade, respeitando, no entanto, o seu desejo de autonomia.

Mas, Charlie começava a ser visto com suspeita por alguns dos membros do Somos, que manifestavam um grande receio de serem usados como "buchas de canhão da esquerda". Apesar de não ter sido o seu autor, foi ele quem sofreu a maior parte dos ataques lançados contra o texto do panfleto que se propunha distribuir no gueto homossexual, em apoio ao Lampião. Mesmo assim, ele continuava a contar com a simpatia de grande parte do grupo. Sua aparência extremamente atraente e seu modo afável tornaram-no muito bem visto, e mesmo querido, até por alguns de seus mais férreos opositores. Todos o "paqueravam" e a todos ele dava atenção e mostras de interesse e afeto. Sua dupla militância não era percebida como "infiltração" e certamente cumpria o papel de estabelecer elos entre o Somos e outras forças mais universalizantes do conjunto da sociedade.

Mas, com esse sucesso, sua atuação dentro do Somos passou a ser mais ousada, na tentativa de estabelecer conexões mais fortes do grupo com a Convergência Socialista, fortalecendo as suspeitas daqueles que receavam que ele desejasse "atrelar" o Somos àquela organização partidária.

Em meados de novembro de 1979, Charlie contatou vários amigos homossexuais, incluindo militantes da Convergência Socialista, colegas seus da Universidade de São Paulo (USP) e alguns integrantes do Somos, cuidadosamente escolhidos. As suas intenções declaradas eram a leitura comentada, em quatro semanas, de um documento interno da Convergência Socialista, que ele e outros homossexuais daquela organização, dentro da qual compunham a chamada Fração Gay, haviam elaborado, com a pretensão de convencer aquele partido a adotar oficialmente uma posição favorável à luta homossexual. O documento, intitulado Tese para a libertação homossexual e contando com 33 páginas, foi entregue com um pedido de sigilo, pois conteria uma discussão sobre casos de discriminação anti-homossexual dentro da própria Convergência Socialista. Uma vez que o que se propunha era um trabalho 
interno para modificar atitudes preconceituosas, era razoável, dizia Charlie, evitar que essa informação fosse usada contra a organização.

Esse pedido foi compreendido e acatado pela maior parte dos integrantes, porém, a forma como as discussões foram conduzidas, dentro de um clima de segredo e mistério, rapidamente chamou a atenção dos integrantes do Somos que não haviam sido convidados. Achando que algo de estranho estava acontecendo, sua primeira suposição foi de que se planejava uma "tomada" do grupo por elementos que pretenderiam desviá-lo para a atuação partidária. Os participantes dessas reuniões secretas ficaram logo apelidados de "beterrabas", por serem "vermelhas e ficarem escondidas embaixo da terra". A situação ficou tão constrangedora que, após duas ou três semanas, Charlie se viu obrigado a fazer uma declaração aos outros integrantes do grupo, explicando o que se passava e que as reuniões convocadas por ele não incluíam nenhuma discussão a respeito do Somos. Embora isso fosse verdade, já nessa época, ele informou a alguns que pretendia organizar, na sede da Convergência Socialista, uma série de discussões sobre marxismo, visando especificamente um grupo de homossexuais. O comparecimento a essas discussões não implicaria em nenhum tipo de engajamento com a organização, mas era clara a sua esperança de, a partir daí, algumas pessoas manifestassem o desejo de se aproximar mais dela. Uma vez esclarecida a situação, o caso caiu em um certo esquecimento, restabelecendo-se, então, a confiança da maioria na sinceridade da militância de Charlie dentro do grupo.

Singer, ao discutir o funcionamento dos movimentos sociais, chama atenção para o importante papel desempenhado por órgãos externos aos movimentos, que podem até constituir seus "aparelhos ideológicos”. Nessas ocasiões, aumenta o perigo do distanciamento entre as bases e os organizadores, especialmente quando esses fazem parte dos organismos ideológicos, aos quais os primeiros não têm acesso. (SINGER, 1983, p. 228) Durante o ano de 1979, esse foi, de fato, o papel desempenhado pelo Lampião, em cujas páginas se podiam ler discussões mais articuladas a respeito de certos temas que eram debatidos dentro do Somos de forma muito mais fragmentada e inconclusiva. Em suas páginas, as posições "anarquistas" tinham quase exclusividade e as organizações político partidárias eram constantemente 
atacadas. Como um dos principais responsáveis pelo jornal em São Paulo - o outro era Darcy Penteado -, Trevisan conseguia destaque para suas ideias, embora já começassem a surgir divergências entre ele e a equipe carioca. Essa tomada de posição, por parte do jornal, aos poucos começou a ser criticada pelos militantes do Somos mais favoráveis às teses do socialismo clássico. Mas, durante vários meses, o Lampião continuou a ser muito influente, não só dentro do Somos, mas em todo o movimento homossexual. Suas ideias se transmitiam pelo país afora, inspirando a criação de novos grupos, primeiramente no Rio de Janeiro e depois em vários outros Estados.

Apesar de se propor a unir o "povo gay" do Brasil, o Lampião acabou servindo para tornar ainda mais evidente a sua heterogeneidade, não só devido às diferenças culturais, regionais, classistas e etárias, mas também entre os próprios "homossexuais organizados". O estopim disso foi a decisão do jornal de promover uma reunião preliminar no Rio de Janeiro para discutir a viabilidade de um congresso nacional de homossexuais. Ele se propunha a pagar as passagens de dois representantes de cada grupo, além de lhes garantir hospedagem na casa de integrantes do recém-criado Somos-Rio de Janeiro. ${ }^{2}$ Durante novembro, e começo de dezembro, esse foi o assunto que dominava as reuniões do Somos e certos detalhes geraram discussões intermináveis, como o status do subgrupo lésbico e a questão da escolha de representantes.

Apesar de ainda serem consideradas como pertencentes ao Somos, as mulheres agrupadas no subgrupo de Atuação Lésbica Feminista receberam um convite em separado para mandarem suas próprias representantes. Esse convite foi significativo e viria a dar respaldo ao sentimento de algumas que desejavam uma organização completamente separada daquela dos homens e, talvez, tenha apressado a formação do grupo autônomo lésbico.

Outra questão delicada era a da representação e essa foi a primeira ocasião em que o Somos se viu forçado, a contragosto, a escolher duas pessoas que falassem em seu nome. Depois de muita discussão,

2 Com exceção do nome, não havia nenhuma outra vinculação entre esse grupo e o Somos de São Paulo 
foram finalmente escolhidos os seus quatro representantes, dois homens, veteranos - um dos quais estava entre os fundadores do grupo e era morador da casa que se tornara uma espécie de sede "não oficial" do grupo, devido ao grande número de reuniões realizadas lá -, e, representando as mulheres, havia uma veterana e uma recém ingressa. Além dos dois representantes de cada grupo, que teriam direito ao voto e à passagem paga, todos os otros que quisessem ir seriam bem vindos, sendo assegurado o seu direito à voz. Assim, vários outros membros do Somos resolveram participar desse encontro também.

A reunião se deu no Rio de Janeiro, no dia 16 de dezembro de 1979, um domingo ensolarado. Havia sido marcada para às nove horas, no prédio da Associação Brasileira de Imprensa, mas, como houvera na véspera uma festa para os representantes que se estendera noite adentro, muitos chegaram atrasados para a reunião. Estavam representados quatro grupos de São Paulo - Somos, LF, Eros e Libertos-Somos-Sorocaba, Beijo Livre-Brasília, e três grupos do Rio - GAAG-Caxias do Sul, Somos-RJ e Auê, este último uma dissidência do Somos RJ, que se constituíra como grupo na véspera da reunião. Apesar da festa, do sol e da praia, todos os integrantes do Somos que haviam ido até o Rio - dez, aproximadamente - acharam importantíssimo comparecer, mesmo se um pouco atrasados.

Durante o seu período de maior lotação, estavam presentes na sala de reunião aproximadamente 60 pessoas. Inicialmente, elegeu-se uma mesa para conduzir os debates, composta por uma das veteranas do Somos-SP e um rapaz negro do Somos-RJ.

Comentou-se que essa escolha refletiria as características novas e progressistas do Movimento Homossexual, que demonstrava, assim, a sua natureza antirracista e antimachista. Mas, as apresentações feitas a seguir, pelos representantes dos vários grupos participantes, mostraram que, apesar de todos expressarem um desejo de maior aproximação entre si, muitas questões e prioridades acabavam provocando um distanciamento entre eles. Discutiu-se a oportunidade de buscar uma atuação em nível nacional, quando nem os grupos do mesmo estado se conheciam direito. Também foram lançadas propostas iniciais para campanhas como a alteração do capítulo da Constituição Federal em que se proibia a discriminação “por sexo”, para que então 
se passasse a constar "por opção sexual". Outra proposta sugeria a modificação do código do Instituto Nacional de Assistência Médica da Previdência Social-INAMPS, para que o homossexualismo deixasse de ser catalogado como "desvio e transtorno sexual".

Mas, a principal preocupação do dia, como não poderia deixar de ser, foi a respeito da viabilidade ou não de um encontro nacional de homossexuais. Depois de muitas discussões, onde ficaram patentes vários desentendimentos entre os grupos, decidiu-se por um encontro, a ser realizado em São Paulo, durante os feriados da Semana Santa - 4, 5, 6 de abril de 1980. São Paulo foi escolhida por ter um número maior de "homossexuais organizados" e ficou a cargo deles a organização do encontro e a elaboração de uma agenda de discussões, a partir de temas a serem previamente sugeridos pelos diversos grupos participantes.

De volta a São Paulo, a grande preocupação passou a ser a organização dessa reunião. $\mathrm{O}$ assunto adquiriu prioridade absoluta, relegando para segundo plano todos os outros interesses manifestados no grupo. Entre os subgrupos voltados à execução de tarefas específicas, somente o de divulgação externa continuou a funcionar, constituindo-se numa comissão preparatória do encontro, juntamente com representantes dos dois outros grupos homossexuais paulistas: o Eros e o Libertos.

Aos poucos, a comissão preparatória do encontro foi se inchando. Esse sentimento de prioridade passou a ameaçar até mesmo o funcionamento dos grupos de reconhecimento que haviam se formado após a reestruturação de outubro, elevando o número de integrantes do Somos para a casa dos sessenta. Além dessas discussões, só uma festa de fim de ano, realizada na chácara de um dos membros do grupo, conseguiu mobilizar as atenções gerais.

Nessa ocasião, foi possível constatar o quanto o Somos mudara em relação a quem o integrava. A grande maioria dos participantes eram novatos e compareceram poucas mulheres e "bichas históricas" - como eram apelidados aqueles que haviam entrado no grupo durante os seus primeiros meses. Embora a festa durasse dois dias e uma noite, estes permaneceram somente algumas horas. Sua retirada foi pouco sentida pelos presentes e isso, aliado às brincadeiras a que haviam sido submetidos - um dos "anarquistas" mais ardorosos 
foi até jocosamente chamado de "stalinista" por um dos novatos -, deixou evidente o quanto os veteranos haviam perdido em importância e prestígio.

\section{O encontro dos grupos homossexuais organizados}

O mês de janeiro viu um esvaziamento do grupo devido às férias e ao declarado cansaço dos veteranos. Além disso, foi um período de relações conturbadas entre os homens e as mulheres do grupo. Em meados do mês, foi feita uma reunião de pouco sucesso, no Teatro Ruth Escobar, para tentar resolver esta situação. As mulheres continuavam a alegar que o grupo não dava a devida importância às questões especificamente lésbicas e os homens as acusavam de divisionismo.

A desmobilização havia atingido um tal estado em que, na reunião de representantes dos grupos do Brasil, realizada em 3 de fevereiro,1980, na Fundação Getúlio Vargas, não se tinha nenhuma proposta para apresentar. Isto abriu um espaço para Charlie atuar, colocando, como representante do Somos, posições e propostas que não haviam sido discutidas anteriormente pelo grupo. Sua atuação deixou insatisfeitos vários dos "anarquistas", que o acusaram de "conchavar" e de usar um "tom panfletário".

Dessa reunião, saiu a decisão de se dividir o encontro em duas partes: uma fechada, na qual só participariam os integrantes dos grupos homossexuais e convidados, e outra, aberta ao público. O encontro fechado contaria com discussões em pequenos grupos, com temas específicos aos grupos organizados e gerais sobre homossexualidade; além disso, haveria reuniões plenárias, onde seriam relatados os resultados das discussões. O encontro aberto seria realizado na tarde de domingo e haveria uma discussão sobre opressão e repressão. Para esta ocasião, seriam convidados representantes de outros grupos minoritários - negros, mulheres e índios -, que teriam tempo para expor seus pontos de vista. Essa divisão do encontro traduzia, em termos práticos, a diferenciação que os militantes começavam a fazer entre categorias de homossexuais, apesar de sua postura teórica de que a estigmatização comum igualava a todos. Note-se que, o espaço reservado aos "não organizados" era aberto ao público em geral e dedicado 
à discussão de um tema que igualava não só os homossexuais, mas todos os grupos "minoritários". Os “organizados" davam ainda outra indicação de que começavam a adotar uma identidade diferenciada ao atribuírem um novo nome ao conjunto de grupos homossexuais, que passou a ser chamado de Movimento Homossexual Brasileiro. Reconhecendo sua particularidade, resolveram que a reunião da Semana Santa deveria ser chamada de "encontro" e não "congresso", para deixar claro que não pretendia ter poderes deliberativos ou representativos dos homossexuais em geral.

Surgia, porém, o problema de como os militantes dos grupos homossexuais autônomos deveriam se relacionar com os homossexuais organizados, dentro das agremiações político partidárias, como os integrantes da Fração Gay da Convergência Socialista. Segundo as ideias vigentes, estes deveriam ser considerados "iguais", mas a sua militância partidária era percebida como séria ameaça à tão prezada autonomia homossexual. Abandonando seus purismos, os representantes dos vários grupos autônomos optaram pelo formalismo casuístico, decretando que só poderiam participar da parte fechada do encontro aqueles grupos que já houvessem enviado representantes a uma das prévias. Impedia-se, assim, a inclusão da Fração Gay da Convergência Socialista. Os preparativos para reunião passaram a ocupar toda a atenção do Somos, cujos militantes tiveram que enfrentar as dificuldades decorrentes de sua falta de experiência e de infraestrutura organizacional. Charlie e alguns simpatizantes ainda tentaram envolver a Fração Gay nessas discussões, mas enfrentaram uma oposição intransigente de outros integrantes do Somos, além dos representantes dos grupos paulistas: Eros e Libertos. Foi finalmente resolvido que a Convergência Socialista só participaria do encontro enquanto colaboradora na organização, sem direito a voto ou a participação na mesa. Este também seria o status de outros participantes como: o jornal Lampião, o Jornal do Gay e do Círculo Corydon.

Concomitantemente, estavam em processo os preparativos para o III $^{\circ}$ Congresso da Mulher Paulista. Este viria a se realizar em março de 1980 e contou com a participação de muitos integrantes dos grupos homossexuais, tanto homens quanto mulheres. As tentativas de 
interferência e sabotagem, por parte da organização MR8, que desejava impedir a criação de um movimento feminista autônomo, serviram para exacerbar, ainda mais, os receios dos que suspeitavam da sinceridade de Charlie e outros simpatizantes da política partidária.

O encontro de grupos Homossexuais Organizados ( $1^{\circ} \mathrm{EGHO}$ ) ocorreu, como proposto, nos dias 4, 5, e 6 de abril de 1980. No encontro fechado, localizado em salas do Centro Acadêmico Osvaldo Cruz, da Faculdade de Medicina da Universidade de São Paulo (USP), compareceram aproximadamente 200 pessoas, incluindo integrantes e convidados dos grupos Auê-RJ, Somos-SP, Somos-RJ, Eros, Libertos, Somos-Sorocaba, Beijo Livre-Brasília, além de participantes vindos de Belo Horizonte, Vitória, Goiânia, Curitiba e uma comissão de representantes do jornal Lampião. À porta, seus nomes eram conferidos numa lista previamente preparada. Um esquema de segurança, contando com a participação tanto de homens como de mulheres - enfatizava-se assim a abolição de papéis de gênero -, certificava-se também de que ninguém levava máquinas fotográficas, já que o único órgão credenciado a fazer a cobertura do acontecimento era o Lampião. Além de evitar a entrada de "penetras", procurava-se, assim, defender o anonimato dos participantes que não desejassem ver sua homossexualidade divulgada nos meios de comunicação de massa. Depois de uma solenidade de abertura, durante a qual a mesa apresentou uma moção de apoio aos metalúrgicos do $\mathrm{ABC}$ que estavam em greve, os participantes se dividiram em vários grupos para discutir os temas previamente propostos. No dia seguinte, houve uma reunião plenária na qual os pontos levantados nas várias discussões foram relatados, e, à tarde, novos debates em grupos pequenos, com uma última reunião plenária no Teatro Ruth Escobar. Os grupos de discussão variavam de tamanho e de clima emotivo, de acordo com os tópicos discutidos.

Os temas haviam sido elaborados a partir de sugestões enviadas por todos os grupos participantes e refletiam, sobretudo, grande preocupação com as questões de identidade homossexual, a constituição de uma comunidade e os métodos políticos a serem adotados pelos grupos e pelo movimento como um todo. A questão da identidade estava refletida na preocupação com os problemas de relacionamento entre os homens e as mulheres, o efeito da imposição de modelos 
preexistentes de homossexualidade, os papéis sexuais, as travestis e as formas de expressão artística e linguística dos homossexuais.

Associada à questão da identidade, estava a da comunidade homossexual e sua problemática heterogeneidade. Pôde-se incluir nesta categoria as discussões sobre a prostituição, a beleza, a discriminação e as violências sofridas por alguns mais do que por outros, a criminalidade e o gueto homossexual. Por último, a questão dos métodos políticos se estendia, desde a discussão sobre a tática do "se assumir" e os problemas do Lampião, até as questões de conjuntura nacional e internacional, como a reformulação partidária, então em curso no Brasil, a relação dos homossexuais com a esquerda e a discussão da própria noção de "poder".

Os debates sobre os diversos tópicos atraíram públicos variados e os que provocaram as discussões mais esquentadas e mais concorridas foram os que se relacionavam à questão lésbica e aos problemas da relação entre política homossexual e política partidária. Os resultados dos debates sobre a problemática das lésbicas estão em outra parte deste livro. Aqui pretende-se somente falar sobre a questão "política".

Apesar dos esforços para manter fora pessoas não ligadas aos grupos homossexuais, compareceram indivíduos cujas lealdades principais pareciam ser voltadas às organizações de natureza político partidária mais clássicas. Ficou evidente que não era somente entre os recém-ingressos do Somos-SP que se encontravam os partidários de uma concepção social informada pelo marxismo. Entre os integrantes de vários dos grupos homossexuais representados, haviam simpatizantes de diversos partidos políticos, legais ou clandestinos, como: o Partido dos Trabalhadores, a Convergência Socialista, o Partido Comunista Brasileiro e o Partido Comunista do Brasil. Procurando encaminhar as discussões para assuntos mais ligados às suas preocupações político partidárias, estas pessoas contribuíram para causar grandes polêmicas, especialmente devido ao receio generalizado de que se reproduzissem no EGHO o caos e o tumulto ocorridos no $2^{\circ}$ Congresso da Mulher Paulista.

Uma das discussões mais acaloradas se deu em torno da proposta de comparecimento dos grupos homossexuais aos atos públicos 
de 19 de maio, em apoio à greve dos metalúrgicos do ABC. Mesmo reconhecendo a importância do evento, muitos, sob a liderança dos veteranos do Somos, se opunham à participação dos grupos homossexuais, alegando a necessidade de se evitar qualquer confusão entre a luta homossexual e a luta classista. Depois de uma conturbadíssima votação, a proposta foi derrotada, apesar da sua defesa ser feita por integrantes do subgrupo lésbico feminista, que diziam que iriam de qualquer forma, por já ter assumido esse compromisso perante o Movimento Feminista. Consumava-se, assim, uma primeira ruptura declarada entre as lideranças tradicionais dos homens e das mulheres do Somos.

Também causou muita animosidade a proposta de criação de uma comissão para coordenar o movimento homossexual em nível nacional. Defendida pelos partidários da "luta geral", ela foi atacada ferozmente pelos "autonomistas", que receavam o aparecimento de um "comitê central", que tentaria impor uma linha comum aos grupos. Essa discussão também serviu para afastar os veteranos do Somos-SP dos militantes cariocas, lançadores da proposta.

A proposta da criação da comissão coordenadora foi, finalmente, derrotada por questões técnicas, pois, como ficara estabelecido, o encontro não tinha poder deliberativo e ficava, portanto, incapacitado de criar qualquer comissão. Apesar de impor o seu ponto de vista através deste expediente técnico, que muitos classificaram como "manobra", os veteranos do Somos acusavam seus opositores de "lutarem pelo poder", e esta acusação logo passou a ser usada por todos os lados envolvidos na disputa. Opunha-se o "poder" à "individualidade", assim, onde houvesse "luta pelo poder" haveria "autoritarismo" e uma tendência à "massificação", ou homogeneização dos anseios e necessidades individuais.

Tornava-se inevitável o reconhecimento de que a suposta comunidade homossexual estava irremediavelmente fracionada e que os antigos valores, cultuados pelos militantes homossexuais como consensuais, eram passíveis de múltiplas interpretações. "A luta pelo poder" se mostrava inevitável e daí por diante até aqueles que regularmente a denunciavam passaram, de maneira declarada, a se preocupar em arregimentar suas forças. 
Essa dificuldade, em aceitar posições políticas conflitantes dentro do movimento homossexual, correspondia a uma certa intolerância em relação às representações tradicionais da homossexualidade, correntes no gueto. Isso ficou evidente durante uma festa de confraternização dos participantes do encontro, realizada na noite de sexta feira, na discoteca gay Mistura Fina.

Durante grande parte da noite, houve muita animação e euforia entre os presentes, que até organizaram um pequeno show satírico. Porém, a certa altura, foi também apresentado o espetáculo que a discoteca oferecia costumeiramente a seus fregueses. Nesse espetáculo, apresentavam-se dois personagens, um "machão", de corpo e porte de halterofilista, e uma conhecida travesti, Phedra de Córdoba. Enquanto o "homem" permanecia de pé, imóvel, com as costas voltadas ao público, a travesti representava um jogo de sedução, estereotipadamente "feminino", fazendo tudo para conquistá-lo, rebolando, insinuando-se, e colocando-se num papel de subserviência.

Rapidamente, a plateia "militante", bastante diferente daquela que normalmente frequentava a casa, foi tomada de mal-estar e murmúrios de descontentamento começaram a ser ouvidos. A certa altura, um rapaz das primeiras fileiras gritou: "Machista, pare com isso!" A plateia aderiu imediatamente ao protesto, vaiando e gritando expressões como "machista", "autoritário", etc. Sem condições de prosseguir, o espetáculo foi abruptamente encerrado.

Menos que a pseudofeminilidade da travesti, o que, provavelmente, mais atiçou a ira dos militantes foi a encenação de um jogo de dominação e submissão, pois, especialmente entre os homossexuais masculinos dos grupos homossexuais, a efeminação e o desmunhecamento básico do "fechar" sempre foram muito praticados e vistos como simples brincadeira. Mais uma vez, evidenciava-se, assim, a crescente distância entre os valores dos militantes e dos habituais participantes do gueto gay.

A tarde do domingo de Páscoa foi dedicada à reunião aberta ao público geral, realizada na sala Gil Vicente, do Teatro Ruth Escobar. Entre 600 e 1000 pessoas estiveram presentes nestas reuniões, incluindo várias travestis e muitas pessoas vindas da periferia, de uma posição sócio econômica bastante baixa. 
Comandando os acontecimentos, havia uma mesa com dez membros dos vários grupos homossexuais de São Paulo, Rio e Brasília, uma travesti, um homossexual negro, do Movimento Negro Unificado, uma representante do grupo feminista Centro da Mulher Brasileira e a Dra. Alice Soares, uma advogada, conhecida, entre outras coisas, por seu trabalho de assistência legal a travestis e aos militantes homossexuais.

A essa altura, já se instalara, entre os participantes, um clima de desconfiança mútua e, deixando de lado os seus tão alardeados princípios, quase todos passaram a "manobrar" e a "conchavar". Um dos principais promotores e alvos dessas operações era Charlie, acusado de manipular suas duplas conexões com a Convergência Socialista e com o Somos, para transmitir a impressão de uma falsa identidade de propósitos entre as duas organizações. Nesse clima conturbado, dois integrantes da mesa tiveram um destaque especial, por sua habilidade em conduzir da forma menos autoritária possível o andamento da reunião: Eduardo do Somos-RJ e Teca do Somos. A atuação de Teca foi elogiadíssima e lhe valeu uma foto na capa do Jornal Lampião. Descrevendo o estilo "bicha", usado pelo presidente da mesa para controlar o plenário, um jornalista daquele periódico disse: "Foi uma delícia ver Eduardo aplacando os ânimos e se aplacando a si mesmo com aquela sua gesticulação de medusa que parece lhe prover de duzentos braços". ${ }^{3}$

Durante a reunião, os vários participantes da mesa falaram rapidamente sobre as diversas formas de opressão sofridas pelas minorias e discutiu-se uma série de reportagens, que haviam sido publicadas pouco antes, no jornal $O$ Estado de $S$. Paulo, atacando a presença de travestis nas ruas da cidade. Foi lida a carta endereçada ao Papa, que o grupo Beijo Livre - Brasília pretendia entregar pessoalmente durante sua programada visita ao Brasil, protestando a respeito das declarações que ele fizera contra o homossexualismo. Foi também feito um relato dos debates entre os grupos e das conclusões a que se havia chegado.

3 Lampião, p. 5, maio 1980 
O restante da reunião foi tomado por depoimentos de homossexuais que protestavam contra variadas formas de opressão e repressão e, na plenária, houve muitos chamados à unidade e a uma luta comum. Porém, os ânimos entre as facções, que se cristalizaram durante a parte fechada, estavam bastante exaltados e houve questionamento da razão de ser da reunião, uma vez que não tinha caráter decisório. Em resposta, Teca definiu a reunião como um "ato público", arrançando demorados aplausos da plateia, por conta do que foi festejado como "seu achado semântico".

Em nível linguístico, as divergências eram expressas nas formas de tratamento usadas pelos oradores. Aqueles que vinham de organizações engajadas em política partidária usavam o costumeiro "companheiro", que era violentamente rechaçado pelos que não desejavam ser vinculados à "luta geral". Estes, por seu lado, não estando acostumados a reuniões desse tamanho, envolvendo tantos grupos diferentes e tantas pessoas desconhecidas, não sabiam quais outros termos usar, empregando repetidamente a expressão "colega", que também parecia pouco apropriada. Eram os termos mais debochados empregados no dia a dia, como "queridinha", "bicha", "santa", etc., que arrancavam manifestações de aprovação e aplauso de um público que via no seu uso um alívio da tensão causada pela seriedade inusitada para uma grande parcela deste público, acostumado a tratar sua orientação sexual de uma forma mais irônica e informal. Ficaram também evidentes várias interpretações existentes sobre o que seria a homossexualidade e a luta homossexual, relativizando, dessa forma, a visão homogeneizadora reinante nos grupos. Trevisan, em seu artigo sobre o encontro, descreve uma dessas situações refletindo na sua linguagem a idealização da marginalidade, comumente evocada naquela época para se contrapor à militância esquerdista.

[...] o travesti da mesa, sem nenhum charme estudado, tomou a palavra e, querendo usar um termo mais fino, declarou que ali todo mundo era 'homem-sexual' do mesmo jeito. Esse homem-sexual soou como uma benfazeja dificuldade em digerir e veicular um conceito que nos discrimina por nos classificar exclusivamente por um aspecto de nossas vidas. 
Esse travesti me lembrou um índio que tivesse mantido suas raízes em plena metrópole, porque tratava-se de um estigmatizado que, aprendendo a falar, não repetia a linguagem de seus estigmatizadores; pelo contrário, modificava-a e por isso tive inveja dele. Ri, deliciado, e pensei inaugurar termos como 'mulher-sexual', 'bicha-sexual', 'lésbica-sexual', etc. Aquele travesti proleta devorava e criava em cima dos seus opressores. E espontaneamente protestava contra a guetoização, inerente ao conceito de 'homossexual', criado para marcar os limites entre normal e anormal. (TREVISAN, 1980, p. 5)

Imperava um clima de grande emoção, todos sentiam que estavam vivendo um momento "histórico", termo usado várias vezes, e que refletia a convicção dos participantes de que o movimento homossexual fazia parte de toda uma série de mudanças, em curso na sociedade, naquele período de "abertura". Alguns observadores, mesmo afastados do movimento homossexual, sentiram-se profundamente tocados, e, em certos casos, não puderam conter suas lagrimas. O clima de emoção foi aumentado pelas tentativas da imprensa de entrar, e equipes de televisão exigiam o direito de filmar os acontecimentos para o noticiário da Globo e para o programa sensacionalista da TV Record, O Homem do Sapato Branco. Essas exigências eram rigorosamente negadas, de acordo com as resoluções da comissão de preparação do encontro, que visavam proteger o anonimato dos participantes.

Quando o encontro chegou ao fim, teve-se como saldo uma série de resoluções aceitas por consenso: chamando pela legalização jurídica dos grupos; a dinamização dos contatos intergrupais, através de jornais e boletins; a promoção de debates sobre a homossexualidade durante o congresso anual da Sociedade Brasileira para o Progresso da Ciência (SBPC); a realização de campanhas para a alteração da constituição brasileira, visando a proteção dos direitos à liberdade de opção sexual e alteração do código da OMS e do INAMPS, abolindo a classificação da homossexualidade como desvio sexual; a denúncia da discriminação exercida por empregadores e o acompanhamento de investigações sobre arbitrariedades cometidas contra homossexuais. Atendendo a questão da autonomia dos grupos em relação à política partidária, recomendou-se que os grupos deveriam se manter abertos à participação de qualquer homossexual que desejasse se aproximar deles. Enfatizou-se 
a importância de se preservar a autonomia do movimento, sem, porém, vedar a participação de seus militantes em "outras linhas". ${ }^{4}$

Embora, na época, parecessem utópicas, muitas dessas resoluções foram postas em prática alguns anos depois, por grupos que nem existiam então. Especial destaque deve ser dado à legalização do Grupo Gay da Bahia e do grupo Triângulo Rosa (RJ) e à alteração na classificação do homossexual, recomendado em 1985, pelo Conselho Federal de Medicina, que sugeria sua inclusão na categoria "Outras Circunstâncias Psicosociais", ao lado de outras condições não patológicas.

Uma importante constatação que pode ser feita a partir dessas resoluções é a da afirmação reiterada da igualdade de todos os homossexuais. Nunca foi colocada em questão a validade da categoria "homossexual”, que atribuía uma só identidade social a um conjunto, mesmo quando sua heterogeneidade ficou tão evidente. Ao invés disso, as diferenças surgidas foram relegadas ao nível individual e interpretadas como manifestações de "alienação" ou "mau caratismo". Mas, a partir desse encontro, o movimento homossexual passou a viver uma nova fase, em que não era mais possível ignorar as diferenças que surgiam em seu seio. Para seus participantes, ocorrera uma "perda de inocência" e ficara claro que não era mais possível um relacionamento baseado em confiança mútua entre as duas facções, em que se agruparam todos os que já tinham uma certa vivência no grupo Somos.

Polarizando as discussões estava a atuação de Charlie, acusado de tentar manipular o Somos em benefício da Convergência Socialista. Desde o episódio das "beterrabas", ele nunca mais conseguira se livrar plenamente das suspeitas de algumas pessoas e seus esforços, para incluir a Fração Gay da Convergência Socialista nos preparativos do encontro, pareciam justificá-las. Aos poucos, dúvidas sobre sua confiabilidade política tornaram-se dúvidas sobre a sua confiabilidade enquanto amigo, pois começou a se alardear que ele teria uma "técnica" de se aproximar de certas pessoas de maneira afetiva para promover fins políticos. Esse tipo de comportamento parecia ameaçar os laços básicos de união entre os membros do grupo, que,

4 Lampião, p. 6, maio 1980. 
retoricamente, consideravam o "tesão" e o afeto mais importantes que a execução de tarefas políticas. Aceitava-se, por exemplo, como desculpa válida por não se ter cumprido alguma obrigação assumida, a alegação de que sua atenção havia sido tomada por algum tipo de aventura sexual ou afetiva. Já fazia algum tempo que se levantavam críticas sobre os supostos "charmes interesseiros" de Charlie. Alegava-se que ele teria até feito curso de treinamento em liderança política esquerdista nos Estados Unidos e que tudo que ele fazia era premeditado. Dizia-se que ele não hesitava nem em levar alguém para a cama só para promover seus fins.

A veracidade, ou não, dessas acusações importa menos que os valores revelados pela interessante contradição manifestada no grupo, que costumava afirmar que o privado era político, mas não se dispunha a admitir o uso político das relações pessoais. O "tesão" parecia ser visto como uma "força natural", espontânea, uma das bases da "individualidade", mesmo que as relações desenvolvidas a partir dele pudessem ser objeto de frios cálculos políticos.

Nesse período de preparação do EGHO, aqueles integrantes com uma visão de mundo mais influenciada pelo marxismo passaram a se encontrar e a saírem juntos, para conversar nos bares do centro da cidade. Surgia um novo grupo de afinidade que se opunha à "panelinha" dos veteranos, ainda quase hegemônica.

Essas pessoas eram identificadas, pelos outros, com Charlie e suas posições, embora entre eles houvessem várias discordâncias políticas, uma vez que eram ligados a organizações políticas diferentes e até antagônicas. Entre eles haviam simpatizantes do PT, CS, PCB, Liberdade e Luta e do jornal Em Tempo. Nesta época, Charlie também tentou incentivar alguns integrantes do Somos a participar da Convergência Socialista, chegando mesmo a distribuir entre eles um novo documento confidencial, aparentemente preparado por ele, intitulado Teses para a libertação homossexual. Muitos destes "mais politizados" passaram a atuar no subgrupo de divulgação externa, no qual eram maiores as possibilidades de dar vazão aos seus desejos de ativismo. Isso, porém, não deixou de atrair as suspeitas do resto do Somos, que sempre vira esse subgrupo com uma certa desconfiança, e receava que esses militantes com interesses partidários traíssem a autonomia do grupo. 
Mais tarde, essas desconfianças mostraram-se plenamente justificadas. Apesar de muitos dos "marxistas" discordarem da política geral da Convergência Socialista, havia uma certa concordância a respeito do que seria uma atuação "progressista" para o Somos. Embora Charlie o negasse, um vazamento de documentos destinados exclusivamente à circulação interna na Convergência Socialista deixou bastante claras, alguns meses depois, as suas pretensões hegemônicas dentro do Somos e do Movimento Homossexual. Esses documentos tomavam como óbvio que ele e seus companheiros se julgavam a direção do "polo progressista" do Somos-SP e davam pouca importância aos seus ideais autonomistas. Isso fica perceptível nas seguintes citações:

Em grupos onde o polo progressista é maior, o imobilismo dos anarquistas vai agudizar as diferenças entre os dois polos. Nesta situação, nossa tarefa vai ser dividir o grupo, levando o polo progressista para uma organização de frente única pró PT.

Após recomendar essa cisão, e a condução do "polo progressista" para uma nova organização pró PT, o documento continua suas prescrições para os homossexuais da Convergência Socialista:

Composta de todos os homossexuais assumidos na Convergência Socialista, a Fração vai levar a questão do homossexual em todas as frentes onde atuamos, dando direção para esses trabalhos. Os companheiros da Fração têm a possibilidade de tornarem-se a direção do Movimento Homossexual nesses setores (i.e., secundaristas, universitários, artistas, bancários, professores, etc.). Em termos superestruturais, a Fração também vai funcionar como um grupo de homossexuais organizados e assim participar de uma eventual coordenação nacional do $\mathrm{MH}$, conferências, jornais, etc.

Temos aí, portanto, a intenção declarada de um setor da Convergência Socialista de tomar a direção do Movimento Homossexual. Mais adiante o documento continua:

A Fração Homossexual da Convergência Socialista vai eleger uma direção com as funções de elaborar as linhas gerais do trabalho da Convergência Socialista e ajudar na formalização 
do trabalho homossexual em todas as regiões. É possível que seja necessário cooptar não homossexuais ao nível da direção nacional para participar na coordenação. ${ }^{5}$

Nessa altura, a pretensa comunidade dos iguais do Somos já estava bastante fraturada. A clivagem entre "veteranos" fundadores e os recém-ingressos era potencializada por uma diferença ideológica entre "anarquistas/autonomistas" e "marxistas". Devido à exigência de consenso dentro do grupo, não havia a possibilidade dessas tendências aflorarem claramente e ser calmamente discutidas em seus prós e contras. Qualquer manifestação de divergência mais acentuada era definida como "luta pelo poder", por aqueles mais influentes dentro do Somos. Portanto, a partir do momento em que a existência de posições antagônicas ficou clara, a única forma de manter a suposta unidade do grupo foi pela adoção de atuações clandestinas.

A participação no Somos afetou profundamente a vida de muitos dos seus membros, e, consequentemente, seus sentimentos a respeito do grupo eram altamente emocionais. Para muitos, o sentimento comunitário, o "casamento com o grupo", continuava a existir, até em meio às crises. Mesmo envolvendo-se em "conchavos" e intrigas políticas, eles se recusavam a reconhecer a natureza fundamental das divisões surgidas, na esperança de que algumas reuniões, ou uma "reestruturação", bastassem para resolver esses problemas. Sua certeza de que o problema básico de todos os homossexuais era a "opressão" os levava a crer que todo "homossexual consciente" acabaria optando pela autonomia do movimento. Qualquer outra opção parecia ser evidentemente "incorreta", ou de má fé. Nem mesmo as diferenças políticas, representadas pela atuação divergente de Charlie, eram completamente apreendidas por muitos integrantes do grupo que, considerando-o "consciente" e incapaz de "agir de má fé", permaneciam confusos perante os acontecimentos. Perdurava assim uma certa relutância em reconhecer o já insanável fracionamento do grupo.

Esse documento em sua versão final, leva a data de setembro de 1980, mas um esboço dele já estava em circulação antes do 1 ○ EGHO. 


\section{As comemorações do 12 de Maio e o "racha"}

A partir do EGHO, as divergências dentro do movimento homossexual se acentuaram dramaticamente e contribuíram para a consolidação, em seu seio, de novas e antagônicas redes de afinidade e sociabilidade. Como importante ponto de discórdia, surgia agora a questão da participação do Somos nas comemorações de 19 de maio, 1980, organizadas pelos metalúrgicos grevistas do ABC e geralmente consideradas um marco histórico na derrubada do regime militar. Previamente, Charlie e seus amigos, entre os "novos", já haviam se manifestado a favor dessa participação, enquanto grande parte dos "veteranos" eram contra.

Em princípio, mesmo aqueles identificados com uma posição contrária à ida do grupo à manifestação, não se posicionavam contra a causa operária em si. Vários se diziam dispostos a ir, mas não como "homossexuais organizados". Protestavam, porém, contra o que consideravam ser uma tendência a se confundir a luta dos homossexuais com a luta de classe, alegando que seria muito pouco provável que os líderes operários estivessem dispostos a dar apoio real aos homossexuais, se estes o pedissem.

Nessa época, Charlie e outros interessados convocaram algumas reuniões, para planejar a ida daqueles que pretendiam participar do ato público. Foi proposto que se levasse uma faixa identificando o grupo homossexual, mas sem usar o nome Somos. Havia grande receio de repressão, tanto por parte das autoridades, que até o final mantiveram uma postura bastante ameaçadora, quanto por parte dos operários. Era a primeira vez que o grupo tentava uma aproximação com a classe operária e havia muito medo de que eles reagissem de uma forma machista e brutal. Charlie propôs que os militantes homossexuais se mantivessem ao lado da representação da Convergência Socialista que, em caso de ataque, estaria disposta a defendê-los. As integrantes do subgrupo lésbico-feminista, que já haviam se comprometido a comparecer ao lado de outras militantes feministas, não se interessaram pelas discussões preparativas dos homens.

Nesse meio tempo, aqueles que se opunham a Charlie e à participação na demonstração começaram assumidamente a "conchavar", reunindo-se secretamente para planejar sua atuação. Em pelo menos 
uma instância, compareceram a uma reunião geral de preparação para a passeata com um esquema diversionista montado para atrapalhar as discussões. Essa atitude foi justificada, mais tarde, com a alegação de que esta era a forma de atuação de Charlie e das outras "beterrabas". Em oposição à ideia de participar do ato público na Vila Euclides, foi proposto um piquenique, onde seria possível se restabelecer um clima mais descontraído, depois de toda a atividade e nervosismo do encontro. Propunha-se lembrar o grupo de que eles estavam juntos para lutar pelo direito ao prazer e que já era tempo do grupo "curtir o seu afeto". Esta proposta foi rechaçada violentamente pelos favoráveis à ida ao ato público, sob a alegação de que era parecida com a do "sistema", que tentava transformar urna data histórica relacionada à luta operária em um simples dia de lazer. Seus proponentes eram sarcasticamente chamados pelos outros de "farofeiras".

No dia 19 de maio, integrantes dos dois grupos se encontraram fortuitamente na cidade, a caminho de suas respectivas atividades. Tal era o clima de desconfiança, que os adeptos do piquenique consideraram que o encontro fora proposital, uma forma de espionagem, para conferir quem seriam os responsáveis pela oposição à participação no ato público.

Os 50 homens e mulheres homossexuais que acabaram participando do ato público, sob a faixa "Comissão de Homossexuais Pró - 19 de maio", foram muito bem recebidos pelos outros manifestantes, o que os deixou eufóricos.

Os que foram ao piquenique também aproveitaram o dia para levar adiante a sua discussão sobre o estado do grupo, que concluíram ser lamentável. Porém, para eles, a ideia de dividir o grupo ou simplesmente deixá-lo era demasiadamente dolorosa. Assim, resolveram chamar uma reunião geral para alertar todos os integrantes sobre o que estaria acontecendo e discutir a atuação de Charlie, vista como comprometedora à autonomia do grupo. Acreditava-se que, dessa forma, seria possível recuperar o Somos.

Durante suas reuniões secretas, os opositores de Charlie e do novo rumo que o Somos estaria tomando fizeram uma análise dos problemas do grupo que, para eles, eram basicamente três.

1. O grupo estaria sem identidade; 
2. O grupo estaria se esvaziando, em termos de número de integrantes;

3. A estrutura do grupo não corresponderia aos anseios, era muito facilmente controlável por indivíduos desejosos de "atrelá-lo" a algum partido político.

Esses, afinal, eram os pontos críticos da tentativa de se organizar um grupo de militância homossexual. A falta de identidade do grupo refletia a própria falta de consistência na noção de uma "identidade homossexual”, que igualava uma população extremamente heterogênea. A própria aplicação ou aceitação do rótulo "homossexual", na nossa sociedade, é basicamente circunstancial e não abarca todas as dimensões da personalidade. O esvaziamento do grupo também correspondia à compreensão de como seriam instáveis as comunicações afetivas baseadas na simples admissão da homossexualidade. O principal atrativo do grupo, para aqueles menos ideologicamente motivados, era o apoio emocional e a possibilidade de sociabilidade que ele oferecia. Quando as brigas internas do Somos começaram a se tornar públicas, o grupo deixou de se mostrar atrativo nesse aspecto. Além disso, essa época foi também marcada por um boom do comércio voltado ao mercado gay e o desenvolvimento do que os militantes chamavam de "gueto". Isso, em parte, era devido à própria atuação dos militantes homossexuais, que lutavam pelo enfraquecimento do tabu que envolvia a homossexualidade, promovendo a sua inclusão no rol da normalidade. Tudo isso contribuía para tornar a participação nos grupos uma opção menos atraente, perante as novas alternativas de sociabilidade oferecidas pelo gueto homossexual.

Já os "problemas da estrutura do grupo" eram basicamente relacionados à impossibilidade da convivência, em seu seio, de concepções muito divergentes. Inevitavelmente, surgiam posições hegemônicas que, embora mascaradas como consensuais, acabavam sendo impostas de forma mais ou menos autoritária, situação bastante comum em outros movimentos sociais deste tipo. (DURHAM, 1984, p. 30)

Na esperança de "salvar a unidade do grupo", através de uma catarse emocional e da retirada de Charlie, os "autonomistas" resolveram convocar uma reunião geral para "lavar a roupa suja". Houve, de fato, duas dessas reuniões, que contaram com o comparecimento da maioria dos integrantes regulares do grupo. As reuniões foram palco 
de colocações passionais, de cunho estritamente pessoal, ao lado de disputas em um nível mais classicamente político. Para os participantes do grupo, não existiria uma separação entre esses dois níveis e era, portanto, considerado legítimo alegar, por exemplo, que aqueles mais interessados em se engajar na "luta geral" eram os que mais adotavam uma postura "macha" no seu modo de andar, vestir, gesticular, etc. - ou seja, não seriam verdadeiramente "bichas", sendo, portanto, lícito desconsiderá-los. Houve, também, a repetição das acusações de "política de cama", "manobrismo", etc.

Nem só Charlie e seus aliados sofreram agressões. Também foi cobrada das mulheres uma maior participação na atuação do Somos e uma definição mais clara de suas lealdades. Afinal, perguntou-se se consideravam em primariamente como homossexuais ou como mulheres? Ainda incertas a respeito dessas questões, as lésbicas resolveram adiar suas respostas sobre o assunto.

Constatou-se claramente que o Somos estava irreversivelmente dividido em, no mínimo, duas facções. Entre as mulheres, havia muito apoio a Charlie, devido às inúmeras críticas pessoais sofridas por ele que, aos olhos de muitas, parecia ter se tornado vítima de um novo "Macarthismo homossexual". Ele continuava irredutível, desafiando seus opositores a tentarem expulsá-lo do grupo.

Depois da segunda reunião de "lavagem de roupa suja”, ficou óbvio que a esperada catarse emocional não estava funcionando e os ataques pessoais promoviam somente o enrijecimento das posições. Mesmo assim uma nova reunião foi marcada para discutir a reestruturação do Somos.

Nesse meio tempo, os opositores de Charlie chegaram à conclusão de que o grupo era "irrecuperável". Como, entre eles, estavam alguns militantes com cargos importantes, tal como o presidente - até então só considerado para efeitos formais ou jurídicos -, se pensou em tentar um ato de força para expulsar os indesejáveis. Mas isto seria difícil, dado o apoio que Charlie gozava e também porque essa atitude era vista como uma capitulação final à "luta pelo poder", justamente a principal bandeira que se levantava contra ele. A partir dessa constatação, resolveram simplesmente abandonar o grupo, procurando levar consigo o máximo de simpatizantes para, juntos, formarem outro. 
As mulheres, cuja atuação é descrita em mais detalhes adiante, também resolveram que o Somos não tinha mais nada a lhes oferecer. Entendiam a briga que se desenrolava como uma disputa entre "machos ambiciosos por poder" e decidiram estabelecerem-se formalmente como o grupo independente, que, há algum tempo, elas já eram de fato.

Porém, o Somos continuava a representar uma ideia extremamente importante e de forte carga emotiva para os envolvidos nesses acontecimentos e muitos ainda acreditavam que seus problemas poderiam ser sanados mediante uma nova reestruturação do grupo. Na data marcada para a primeira reunião após as "lavagens de roupa suja", como de costume, o início das discussões se atrasou e os militantes, ao chegarem, se agrupavam em rodinhas de conversa, à porta do local escolhido para a reunião, a discoteca gay Mistura Fina, localizada na Rua Major Sertório, na chamada "Boca do Lixo". ${ }^{6}$ Reinava um clima inesperadamente ameno, ao contrário de outras reuniões do grupo. Dois rapazes de atuação destacada no Somos, contrariando o uso costumeiro, haviam vindo semitravestidos. Ambos estavam de sapatos de salto alto, calças, túnicas de aparência feminina, com os olhos, a boca e o rosto maquiados, embora um também ostentasse bigodes. $\mathrm{O}$ outro estava com o cabelo penteado em estilo feminino, uma grande quantidade de colares de candomblé pendurados no pescoço e várias pulseiras nos braços. Suas aparências foram bastante comentadas, embora não de forma desaprovadora, mas ninguém parecia se perguntar porque eles haviam vindo assim. Aqui, cabe ressaltar que a forma costumeira dos integrantes do grupo se vestirem era das mais corriqueiras: o uniforme unissex da juventude, cuja marca básica é o brim, usado especialmente em forma de calças e jaquetas. Normalmente, nem os homens e nem as mulheres usavam maquilagem ou arranjos de cabelo mais elaborados.

6 Por estar acometido de hepatite, tive de me afastar do grupo durante quase dois meses e essa foi, justamente, a primeira grande reunião que assisti depois de restabelecido. Embora estivesse ciente das graves divergências internas, pelas quais o Somos passava, acreditando até na possibilidade de uma facção tentar expulsar a outra, muitas surpresas me aguardavam. 
Quando a reunião foi dada por iniciada, todos se sentaram em círculo na pista de dança da discoteca. Eram trinta e sete homens e vinte e oito mulheres. No momento inicial, de leitura da pauta para a reunião, foi anunciado que Evaristo, um dos veteranos do grupo e ator profissional, faria primeiro um comunicado importante. Houve um silêncio, enquanto ele assumia uma expressão digna, de quem estava para fazer uma declaração histórica. Evaristo passou então a ler, de forma pausada, o seguinte texto:

Ao Grupo Somos

Considerando que a imagem externa do Grupo Somos está irreversivelmente associada ao grupo Convergência Socialista; Considerando que a autonomia do Grupo Somos está comprometida pelo caráter da atuação de elementos filiados a organizações políticas e partidárias;

Considerando que o Grupo Somos foi desviado de sua definição como grupo de homossexuais interessados basicamente em discutir nossa sexualidade e lutar contra a discriminação sexual;

Nós, abaixo nomeados, nos declaramos desligados do Grupo Somos a partir desta data, e passamos a constituir um novo grupo que se propõe a reafirmar a definição do grupo homossexual autônomo e interessado prioritariamente na questão homossexual.

Às pessoas dispostas a integrar o novo grupo, comunicamos que nossa primeira reunião deverá realizar-se no dia 25 de maio de 1980, domingo, às 16 horas, em local a ser definido.

São Paulo, 17 de maio de 1980.

Cacá, Celso I, Emanoel, Evaristo, Glauco, Reynaldo I, Ricardo III, Tosta, Zezé.

Terminada a leitura, os nove assinantes da carta se retiraram sem mais comentários, seguidos por dois rapazes que fizeram pequenos discursos, que se pretendiam improvisados. Declaravam uma concordância com o documento lido e manifestavam uma adesão "espontânea” ao novo grupo. Eles, então, também se retiraram do recinto. Porém, ficou pouco clara a intenção destes últimos e só mais tarde vim saber que era uma tentativa premeditada de estimular a retirada maciça dos descontentes. 
Vitório, o último a manifestar a sua adesão, fora um dos que viera semitravestido - o outro fora Zezé, um dos signatários da carta - e, depois de seu pequeno discurso, atravessou a pista de dança com ar solene, apesar de demonstrar uma certa dificuldade em se equilibrar nos seus saltos altos. Ficou bastante óbvio que ele viera preparado para um "acontecimento histórico". Isso conflitava de tal modo com sua "adesão espontânea”, que sua fala acabou sendo interpretada como uma simples "manifestação de estrelismo", pela plateia atônita.

Uma vez que os dissidentes haviam saído, houve um clima de indignação geral por parte daqueles que permaneciam no Somos, mas não se consideravam ligados, de nenhuma maneira, à Convergência Socialista. Quando os ânimos se acalmaram um pouco, as mulheres anunciaram que haviam chegado à decisão de sair do Somos, por acharem impossível um grupo feminista coexistir dentro de um grupo maior, também integrado por homens. Ao mesmo tempo, disseram lamentar a coincidência das duas saídas, pois as razões que elas tinham para sair eram diferentes.

Porém, uma das integrantes do grupo, Alice, manifestou sua discordância com essa separação, alegando que ela e seu "caso" não desejavam interromper uma experiência que, para elas, estava sendo muito rica. Além disso, diziam nunca ter passado dificuldades com os homens do grupo, ao passo que, em várias ocasiões anteriores, já haviam entrado em choque com uma "cúpula" formada por quatro ou cinco mulheres, que tentavam controlar toda a atuação lésbica-feminista. Essas duas eram as únicas que não haviam participado da reunião, na qual as mulheres haviam resolvido se desligar do Somos. Para resolver essa situação, todas se retiraram para uma sala separada, onde, depois de uma discussão, foi votada a confirmação da decisão de saída do grupo e ficou explicitado que não seria permitida a dupla militância dentro do Somos e do grupo lésbico-feminista. Forçada a escolher entre os dois, Alice resolveu ficar com o Somos, no qual ela e sua companheira passaram a ser as únicas mulheres.

Com a saída desses dois segmentos do Somos, somando aproximadamente trinta e nove pessoas, o grupo que restou se sentiu muito abalado mas continuou a reunião. Não era mais viável discutir uma reestruturação, pois tornava-se necessária uma pausa para 
reflexão sobre o significado do ocorrido. Apesar de espantados com os acontecimentos, vários dos presentes expressaram uma certa satisfação, pois haviam saído os elementos discordantes e os que ficaram pareciam ter opiniões bastante homogêneas. A maior discordância nesse momento era a respeito da saída das mulheres, já que muitos homens diziam que a experiência de pertencer ao grupo se empobrecia sem a presença das lésbicas para "apontar tendências machistas” e confrontar a experiência homossexual masculina e feminina. Alguns defendiam a saída das mulheres, repetindo as alegações delas de que a luta lésbica era essencialmente feminina. Porém, em um ponto, eram quase unânimes: não se acataria o pedido das mulheres separatistas de que o Somos se tornasse exclusivamente masculino, enviando candidatas a integrantes para o grupo lésbico-feminista. A certa altura, o trabalho de limpeza da discoteca tornou necessário esvaziar o salão e, sem chegar a nenhuma conclusão, o grupo, ainda aturdido, resolveu, como sempre, chamar outra reunião geral de emergência.

Com esse incidente, ficou claramente marcado o fim de uma fase do Somos, na qual as diferenças internas eram camufladas por um espírito grupal, fortalecido, durante algum tempo, pelo sentimento do comunitas da época do "casamento com o grupo". Porém, chegou um momento em que esse espírito grupal teve de ceder lugar a uma estrutura mais burocratizante, em que uma pequena "cúpula" exercia informalmente a liderança.

A questão da tentativa de "atrelamento" do grupo, por parte de militantes da Convergência Socialista, embora tenha sido um fator relevante, não deve ser vista como uma explicação suficiente Não se pode deixar de também levar em conta as dificuldades apresentadas pela suposta "identidade homossexual", que embasaria toda a atuação do Somos. Devido à generalização do estigma homossexual, atribuía-se a essa identidade uma uniformidade espúria, que deveria se sobrepor às diferenças de idade, classe, raça, religião, filiação partidária, etc. Assim, o recurso de dois rapazes ao semitravestismo buscava enfatizar a homossexualidade "verdadeira" dos "autonomistas" e, implicitamente, pôr em questão a dos acusados de atrelar o grupo à política partidária. Nessa ocasião, não faltou nem mesmo um apelo ao 
gueto homossexual, geralmente tão malvisto pelos militantes por sua "futilidade". Zezé explicou, mais tarde, o incidente da seguinte forma:

Agora, quanto à gente ir maquiado na reunião geral, a gente queria assumir mesmo o nosso lado bicha. A gente não quer fazer a apologia da bicha do gueto, a gente queria dizer para as pessoas que a gente vai lutar muito prá tentar se aproximar, o máximo possível, das bichas do gueto, porque nossa preocupação é essa, acima de tudo. Aliás, não foi proposta do grupo, foi em um bate-papo que eu tive com o Vitório. Como sair do Somos? Eu vou me sentir mutilado, eu vou ter que me sentir muito lá em cima, para conseguir aguentar a coisa. Realmente, eu fui com as pernas tremendo. Foi também uma transação emocional, individual nossa, ou seja, duas pessoas que estavam terrivelmente ligadas com o ativismo do grupo, para conseguirem se desligar do grupo, tiveram que assumir um astral muito incrível, para a gente poder ser sedativo nosso. (Zezé)

A tentativa de desqualificar os "agentes infiltrados da Convergência Socialista", negando-lhes a identidade homossexual, foi levada até mais longe. Um deles foi acusado de ser, de fato, "heterossexual" e de namorar outra militante daquela organização, também envolvida na tentativa de "atrelar" o Somos à Convergência Socialista. Essa alegação, de natureza bastante fantasiosa, chegou até a ser aceita por rapazes que tinham eles mesmos, mantido relações sexuais com o "agente duplo" em questão. Os "anarquistas" pareciam, portanto, querer tomar para si a quase exclusividade da identidade homossexual.

Incapazes de enxergar as descontinuidades e heterogeneidades da homossexualidade e ansiando pela catarse emocional do comunitas, os militantes do Somos recorriam, assim, muitas vezes, a explicações simplistas baseadas em visões caricaturais do marxismo, do feminismo, do gueto ou da história, em sua busca por legitimidade. 


\section{A campanha contra a violência policial}

Como se tem visto, o movimento homossexual brasileiro, da mesma maneira que outros movimentos estruturalmente similares, foi marcado por um grande fracionamento interno. Formou-se uma multiplicidade de grupos, cada um zelosamente defendendo a sua "autonomia", contra a ingerência, não só do Estado ou de organizações com fins mais abrangentes, como partidos, sindicatos, etc., mas também de outros grupos, de finalidades e estruturas mais parecidas às suas. Eunice Durham atribui isso à dinâmica interna desses movimentos baseados no sentimento de comunidade e do compartilhamento de experiência. Como esse comunitarismo só é possível em grupos relativamente pequenos, o crescimento só pode ocorrer através de uma atuação conjunta ampliada. Essa tendência à pulverização seria agravada, ainda mais, pelo fato de que decisões, nesse tipo de organização, só podem ser tomadas por consenso, causando frequentes cisões internas. (DURHAM, 1984, p. 28)

Já vimos as dificuldades causadas pela exigência de consenso para qualquer resolução do Somos, veremos agora alguns desenvolvimentos que se seguiram ao fracionamento do grupo original em três outros grupos. 
Depois da saída dos dois grupos dissidentes, os homens e mulheres que permaneceram foram tomados de sentimentos contraditórios. Por um lado, ficaram abalados com a quebra da unidade do grupo e com o seu consequente enfraquecimento, por outro, sentiram alívio com a saída de uma facção que, nos últimos tempos, se tornara extremamente incômoda, devido à sua posição política divergente. Como ficou evidente mais tarde, devido ao "vazamento" de alguns documentos internos da Convergência Socialista, tal divisão do grupo já tinha sido até cogitada e planejada por Charlie, juntamente com um ou dois de seus colaboradores mais íntimos. Estes interpretaram o ocorrido como sendo "uma opção política".

Mas, em momento algum, os que restaram sentiram abalada a sua identidade enquanto Grupo Somos. Mesmo com a saída de tantos "veteranos" e fundadores do grupo, haviam ainda alguns que representavam a continuidade entre os atuais membros, na sua maioria recém-ingressos, e as primeiras atividades dos "tempos áureos", do começo de 1979. A todos irritou a acusação de que o Somos havia perdido a sua autonomia e de que sua imagem externa estava "irreversivelmente associada à Convergência Socialista”. Embora muitos fossem simpatizantes do socialismo e de sua interpretação marxista para a sociedade, poucos desejavam uma ligação mais estreita entre o Somos e a Convergência Socialista. Alguns continuavam a achar essencial a autonomia do grupo, enquanto outros eram simpatizantes de outras tendências de esquerda. A sua reação foi a previsível. Convocaram outra reunião geral e tentaram restabelecer a normalidade do funcionamento da organização.

Muito mais traumatizante foi a experiência dos homens dissidentes. Uma vez lido o documento que anunciava a cisão formal do grupo, seguida por sua solene retirada do salão do Mistura Fina, os onze não conseguiram mais manter a sua altivez e entraram em profunda depressão. Dirigiram-se à Praça Roosevelt, o monstro de concreto situado nas vizinhanças da discoteca, onde ficaram sentados, em silêncio, olhando o tráfego intenso da Avenida Consolação. Passado um bom tempo, o grupo se dispersou, indo cada um para o seu lado. Alguns teriam até chorado.

Essa depressão era compreensível e esperada. Entre os onze estavam alguns dos fundadores do grupo, alguns daqueles que pouco 
antes se diziam "casados com o grupo" e cujo assunto permanente de conversa era o Somos. Entre eles, estavam alguns que vinham cedendo suas casas ou apartamentos para reuniões, a tal ponto que uma ou duas dessas residências se haviam tornado sedes informais do grupo. Durante meses, eles haviam assistido a longuíssimas e, ultimamente, cada vez mais frustrantes reuniões. Como elas se sucediam várias noites por semana, aqueles que precisavam levantar cedo para trabalhar tiveram que se sujeitar a um sono de poucas horas por noite. Para a maioria, o grupo havia se confundido com seu círculo de amigos, pois era muito comum os seus integrantes perderem contato com suas antigas amizades, depois de entrar no Somos. Durante as várias reuniões que esse grupo de dissidentes havia feito para discutir a tentativa de "recuperação" do grupo, sempre houvera uma grande relutância em considerar uma possível debandada. Devido ao fato de que entre os dissidentes estavam as pessoas com os principais cargos burocráticos, até o final se acalentava a ideia de arrastar um número expressivo de militantes e manter o nome "Somos" para o grupo dissidente, deixando, a Charlie e seus simpatizantes a tarefa de criarem um outro nome e uma nova identidade.

Embora ninguém os tivesse seguido na sua saída da reunião no Mistura Fina, no dia programado para a reunião do novo grupo, vários outros simpatizantes vieram e parece ter sido aí que se resolveu formalmente abdicar de todas as pretensões sobre o patrimônio e a identidade do Somos. Adotou-se provisoriamente o nome "Ação Homossexualista". As reuniões seguintes foram tomadas por longas análises sobre os erros cometidos e que teriam permitido tal "desvirtuamento" do Somos.

Por azar, na semana seguinte à cisão, ocorreu um incidente que iria servir como catalizador de todos os ressentimentos nutridos, tanto por um lado quanto por outro. A revista Veja, interessada em uma matéria sobre os movimentos minoritários, enviou um repórter para entrevistar os vários grupos homossexuais de São Paulo. Tal era o estado de espírito de todos os envolvidos na questão do Somos, que aqueles identificados com a dissidência, contrariando uma velha suspeita que o grupo sempre nutrira em relação à grande imprensa, fizeram detalhadas revelações ao repórter a respeito do "racha". 
Expuseram também seus receios sobre a atuação de Charlie, que estaria direcionada a colocar o grupo Somos - e talvez até o Movimento Homossexual - sob a direção da Convergência Socialista.

Quando o mesmo repórter entrevistou os representantes do Somos e mostrou, ao perguntar sobre a atuação partidária dentro dos grupos homossexuais, o quanto já lhe havia sido revelado, esses finalmente encontraram um bom pretexto para extravasar sua santa indignação. Usando um termo empregado inicialmente pelo próprio Charlie - e que até então nunca fizera parte do vocabulário do grupo -, começaram a acusar os dissidentes de "deduragem", alegando que nessa época a Convergência Socialista estava sofrendo violenta campanha de intimidação por parte do governo, à procura de bodes expiatórios para explicar a onda de insatisfação que se alastrava pelo país. Também foi alegado que Charlie, como estrangeiro, a exemplo de outra militante da Convergência Socialista de nacionalidade americana, poderia ser deportado a qualquer instante. Imperava um clima de intensa emoção e amargura. Até velhos amigos e antigos "casos" logo começaram a brigar entre si, só por se encontrarem em facções opostas nessa disputa.

Comprovando a já sobejamente reconhecida importância do jornal Lampião para o Movimento Homossexual, uma das primeiras reações, tanto do lado da Ação Homossexualista quanto do Somos, foi a de escrever cartas expondo os respectivos pontos de vista, na esperança de que fossem publicadas. De fato, embora o jornal, desde os seus primeiros números já viesse lançando ataques esporádicos contra a Convergência Socialista, Lampião, no seu número de junho/1980, divulgou democraticamente as três cartas, enviadas pelas mulheres, pelo Somos e pelos dissidentes.

\section{A campanha anti-Richetti}

Paradoxalmente, foi durante sua maior crise que o Somos, ou melhor, seus fragmentos, conseguiu realizar a maior prova de sua presença e atuação. Poucos dias após a divisão, as polícias militar e civil de São Paulo começaram uma ação conjunta no centro da cidade que ficou conhecida como "Operação Rondão" ou "Operação 
Limpeza". A primeira notícia que o grupo recebeu a respeito foi durante uma festa promovida pelo Somos na discoteca "Mistura Fina". Dois integrantes do grupo, que haviam sido presos na rua e detidos na $49^{a}$ Delegacia durante mais de duas horas, apesar de estarem com todos os seus documentos em ordem, chegaram e anunciaram pelo sistema de som o que lhes tinha ocorrido.

Nos últimos meses, o clima de "abertura" e a gradual liberalização da censura haviam permitido que os homossexuais paulistanos se sentissem cada vez mais seguros, pelo menos na área conhecida como o "gueto". Nessa época, por exemplo, foi várias vezes comentado que "São Paulo estava virando uma San Francisco". Essa impressão era devida à proliferação de estabelecimentos orientados para uma clientela gay e à descontração com a qual homens e mulheres estavam começando a andar pelas ruas, abraçados com parceiros do mesmo sexo e, em alguns casos, até se beijando na boca. Durante essa época, também pareciam se tornar mais evidentes as travestis que, segundo se dizia, estariam tomando todos os tradicionais pontos de prostituição, deixando as prostitutas sem clientela. (PERLONGHER, 1987, p. 86)

Mas, durante este período, forças conservadoras montavam a sua reação. Órgãos da imprensa sensacionalista, como os jornais Notícias Populares e Folha da Tarde, mantinham sua tradicional postura moralista, apelando regularmente à polícia para que defendesse a sociedade contra uma série de vícios descritos em detalhes para a delícia dos leitores. A atuação dessa imprensa, muitas vezes considerado órgão oficioso da polícia, não surpreendia ninguém. Desde os seus primórdios, o Somos debatia sobre o que fazer a esse respeito, mas a novidade foi uma série de artigos publicados pelo O Estado de S. Paulo em que se fazia uma campanha pela erradicação das travestis, especialmente aquelas que faziam ponto em áreas residenciais de classe média alta, como a Avenida República do Líbano. Esses artigos eram de uma violência inusitada para o sisudo jornal, embora sua tônica anti-homossexual não fosse nova para a empresa onde se dizia que a família Mesquita, dona do jornal, normalmente censurava qualquer tipo de referência à homossexualidade.

Com a transferência, para a terceira Seccional (Centro), de um delegado que se tomara conhecido na década anterior por ter expulso 
as prostitutas de São Paulo e criado a zona de prostituição de Santos, foi dado início a uma brutal campanha contra os frequentadores noturnos do centro da cidade. Esse delegado - José Wilson Richetti - contava com o beneplácito de seus superiores, o Secretário da Segurança, desembargador Otávio Gonzaga Júnior, e o chefe do Departamento de Polícia da Grande São Paulo, delegado Rubens Liberatori. Este também estivera envolvido na "Operação Camanducaia", de 1974, quando menores infratores de São Paulo foram levados para os arredores de uma cidadezinha do interior de Minas Gerais e soltos nus. Alegava-se, também, que o general Milton Tavares, comandante do II Exército, dava seu apoio à operação.

Durante as primeiras semanas da campanha, a polícia passou a efetuar "batidas" no centro da cidade, em horários irregulares. Aqueles que não estivessem portando uma carteira de trabalho assinada eram levados para aguardar triagem na delegacia, onde costumeiramente eram obrigados a passar, no mínimo, uma noite. Em pouco tempo, conseguiu-se dispersar os homossexuais da região. Estes deixaram de ser vistos nas ruas para se concentrarem nos estabelecimentos fechados, como boates, onde pareciam gozar de uma certa imunidade. Não era somente a militância homossexual que enfrentava mudanças, toda a política partidária paulista também passava por um período de grande efervescência. O PT estava em vias de se formar e os políticos oposicionistas viam nesse momento de "abertura" a possibilidade de deixar suas marcas, talvez pensando na campanha eleitoral de 1982. A sociedade estava bastante mobilizada e havia uma proliferação de grupos e movimentos de todos os tipos. Tanto o Movimento Negro quanto o Movimento Feminista atravessavam períodos de entusiasmo e crescimento. Nesse cenário, a proposta de mobilização contra a violência repressiva do Estado evocava uma concordância quase unânime.

As feministas, após o Encontro de Valinhos, já haviam voltado suas atenções para as questões da violência contra a mulher e da sexualidade. Formara-se, também, uma comissão encarregada da condição da prostituta. Esta havia mantido contatos com algumas dessas profissionais que já tinham organizado anteriormente protestos contra a violência a que estavam expostas. Os negros, por seu turno, haviam, 
há muito, eleito a violência policial como um dos principais alvos de suas campanhas.

Neste momento, a violência, desencadeada por um organismo estatal serviu como poderoso unificador de movimentos sociais. Através dos contatos que o movimento homossexual havia conseguido com sua política de alianças, foi armada uma campanha contra o delegado Richetti e sua "Operação Limpeza”. Participaram, principalmente, os movimentos homossexuais e feministas, este, em defesa das prostitutas, mas também deram apoio o Movimento Negro Unificado, o Departamento Jurídico do Centro Acadêmico XI de Agosto, alguns parlamentares, destacando-se aqui os deputados estaduais pelo PT, Eduardo Matarazzo Suplicy e João Batista Breda. Outros políticos como: Irma Passoni, Fernando Morais e Geraldo Siqueira também participaram, mas restringindo seus interesses somente à problemática feminina ou à questão de direitos humanos, esquivaram-se, nessa ocasião, de qualquer comprometimento maior com a questão da homossexualidade: Também colaboraram grupos políticos como a Convergência Socialista, os jornais O Trabalho e Em Tempo. Embora o trabalho de base fosse feito pelos grupos homossexuais e feministas, que convocaram um ato público para 13 de junho de 1980, a notoriedade pelo evento ficou com celebridades como a atriz Ruth Escobar e o pintor e membro do Conselho Editorial do Lampião, Darcy Penteado. Estes, quer estivessem em comissões de parlamentares, quer estivessem sozinhos, demonstraram rara tenacidade e coragem ao enfrentar o temido aparelho de repressão paulista e ao não se acabrunhar em ver seus nomes envolvidos em uma causa tão escandalosa para a época.

A campanha contra o Delegado Richetti funcionou em duas frentes. Por um lado, os grupos homossexuais, feministas e negros programaram um ato público. Por outro lado, parlamentares oposicionistas, militantes feministas, estudantes e as celebridades Ruth Escobar e Darcy Penteado chamaram a atenção da imprensa para as arbitrariedades que estavam ocorrendo e promoveram uma convocação por parte do Conselho Parlamentar de Defesa dos Direitos Humanos para que o Delegado Richetti comparecesse à Assembleia Legislativa e prestasse esclarecimento sobre o que se passava. 
Como não podia deixar de ser, a organização da passeata foi palco de várias desavenças, entre os fragmentos do antigo Somos. As integrantes do recém-batizado GALF -mais conhecido como LF - e o Somos concordavam na necessidade de se fazer um ato público em um lugar aberto, seguido de uma passeata. Desta ideia discordavam os integrantes da Ação Homossexualista - nesta época chamados de "chicórias" pelo Somos, pois espalhara - se o boato que uma das alternativas propostas por eles para um nome do grupo havia sido "Chicórias em Delírio", talvez em contraposição às "Beterrabas", os "vermelhos" do Somos. Eles propunham que se fizesse um ato público em recinto fechado, onde mais simpatizantes pudessem comparecer, sem medo de terem suas fotos estampadas em jornais no dia seguinte. Além disso, eles viam esse ato como tendo um caráter mais exclusivamente homossexual, enquanto que o Somos defendia a inclusão de outros setores discriminados, incluindo os desempregados.

Outro ponto de desavenças dessa época foi a aliança que se formou entre os grupos homossexuais paulistas Eros, Libertos e Ação Homossexualista, que se denominou "Movimento Homossexual Autônomo". À parte o nome, que foi interpretado pelos integrantes do Somos e do GALF como uma referência direta à sua suposta falta de autonomia, o que os deixava furiosos, outro desentendimento resultou da insistência dessa frente em ter direito a três votos, mesmo que somente um de seus representantes estivesse presente nas reuniões preparatórias do evento. O MHA também se recusava a funcionar "como partido" e não aceitava tarefas que implicassem num ativismo compulsório para seus integrantes. Dizendo que um "tarefismo" exacerbado estava relegando a discussão de problemas homossexuais para um segundo plano, eles sustentavam que seus integrantes só participariam na campanha se assim decidissem individualmente.

Finalmente, concordou-se em fazer um ato público em frente ao Teatro Municipal, no dia 13 de junho,1980, às 18:30 horas. Filipetas convocatórias foram distribuídas, entre a população em geral e também no gueto homossexual especificamente. À hora determinada, alguns representantes dos grupos organizadores falaram, perante um público composto predominantemente de homossexuais, embora algumas organizações políticas, como a Convergência Socialista, também 
levassem suas faixas. Poucos militantes políticos heterossexuais, engajados na luta partidária, compareceram e nenhum parlamentar. Os negros também tiveram uma participação bastante reduzida e a única "celebridade" a comparecer foi Darcy Penteado. ${ }^{1}$

As estimativas sobre o número de pessoas envolvidos no ato variam de 500 a 1000, o certo é que os números foram aumentando durante a passeata que se seguiu ao ato público. Essa passeata andou pela Avenida São João, parando o tráfego sem ser molestada pela polícia, e se dirigiu ao edifício Século XX, na praça Júlio Mesquita, famoso por abrigar um grande número de prostitutas. Muitas destas desceram e engrossaram a passeata que então rumou ao Largo do Arouche, centro do gueto homossexual, e depois à Boca do Lixo, área de prostituição.

Durante a passeata, palavras de ordem tradicionais eram cantadas e, muitas vezes, adaptadas para aquela situação. Outras palavras de ordem, mais insólitas, foram criadas na hora. Assim, um alegre bando, predominantemente masculino, desfilou pelo centro de São Paulo se abraçando, se beijando, rebolando, desmunhecando, "fechando" enfim, entoando palavras de ordem como as seguintes:

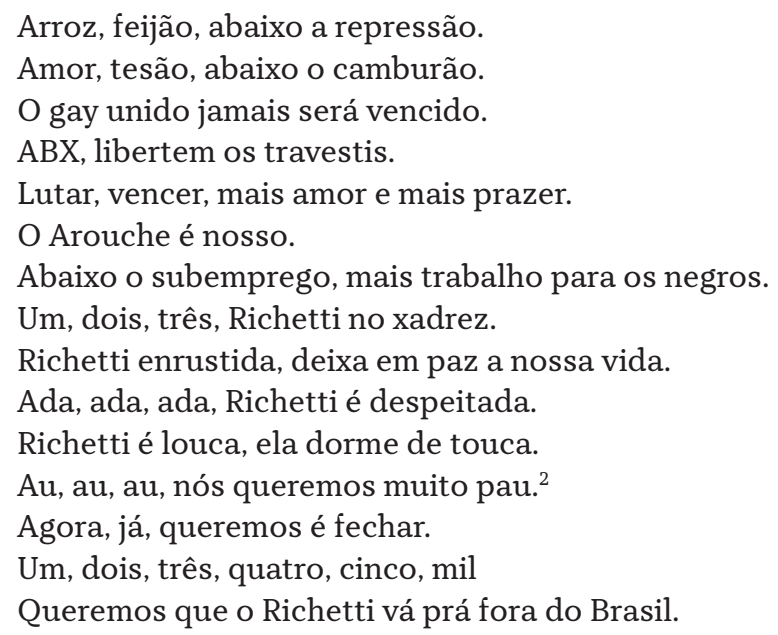

1 Sobre a manifestação anti-Richetti e outras ações políticas de homossexuais organizados durante a ditadura. (GREEN; QUINALHA, 2014)

2 Palavras de ordem colhidas por Trevisan, publicadas no Lampião, p. 18, jul. 1980 
Homem com homem, mulher com mulher.

Bicha com bicha, Richetti não quer.

Libertem nossas bichas.

Libertem os travestis.

Nós somos as bichinhas do Somos“

Levando a vida a militar

De tarde nós discutimos

À noite vamos panfletar ${ }^{3}$

A passeata transcorreu calmamente, apesar de ser seguida, o tempo todo, por vários carros, obviamente da polícia. Dizia-se até que o próprio Dr. Richetti estaria lá. O único problema foi um tumulto que ocorreu nas proximidades do Hotel Hilton, já no final do roteiro, e que serviu para dispersar os manifestantes, quando estes, repentinamente acreditaram estar sendo atacados.

A reação do público que assistiu à passeata geralmente era um misto de curiosidade e riso. Houve poucas reações de agressão, a mais séria sendo o arremesso de um pesado grampeador de papéis do alto de um edifício da Avenida São João. Por sorte, ele não atingiu ninguém, pois de outra forma poderia facilmente ter causado uma morte.

Além dessa passeata "fechativa" e escandalosa, na qual predominaram os militantes homossexuais e os frequentadores do gueto, a luta contra a "Operação Limpeza" também contou com um evento mais convencionalmente "político". Foi quando se recorreu a uma das instâncias do Estado, o Conselho Parlamentar dos Direitos Humanos que convocou o Dr. Richetti para prestar depoimento sobre suas atividades no Centro. No dia 30 de junho, este compareceu à Assembleia, acompanhado de um elevado número de policiais que eram seus amigos. No plenário estavam cerca de 300 interessados, entre partidários da "Operação Limpeza" - uma associação de moradores e lojistas do centro da cidade - e integrantes de vários grupos homossexuais e feministas integrados na campanha.

Infelizmente, os deputados compareceram muito mal preparados para os debates. Além dos oposicionistas, havia um numeroso grupo do Partido Democrático Social (PDS) que, embora minoritário no

3 Palavras de ordem recolhidas por J. D. Gaspar. Cantado seguindo a música: "Cantoras do Rádio". 
Centro de Promoção e Defesa dos Direitos Humanos (CPDDH), fez o possível para amenizar o interrogatório do delegado. Ocorreram alguns incidentes, como quando foram retiradas dos anais da reunião as falas de Ruth Escobar e de Darcy Penteado. O deputado Geraldo Siqueira havia proposto uma moção de censura ao delegado, assim como uma proposta de que ele fosse processado, administrativamente e penalmente, mas, quando chegou a hora da votação da moção, a maioria dos deputados, inclusive Geraldo Siqueira, haviam deixado o recinto, o que impediu seu encaminhamento.

Durante os contatos preliminares dos militantes com os deputados, ficou patente o receio que eles demonstraram de ofender as convicções moralistas do seu eleitorado. Este receio não era totalmente infundado, como ficou claro numa reportagem bastante negativa publicada no jornal O Estado de S.Paulo que terminava da seguinte forma:

Na porta principal da Assembleia Legislativa, uma das 20 senhoras presentes criticou os deputados do Conselho dizendo que, em momento algum, quiseram ouvir o povo e perguntar como vivem as famílias nos prédios frequentados por prostitutas, travestis e trombadinhas. ${ }^{4}$

Em geral, a cobertura da imprensa, com exceção da Folha de S. Paulo e Isto É, foi bastante desfavorável e desrespeitosa. O Diário da Noite, por ocasião da passeata, falou em "Protesto das Bonecas" e insinuou que estes haviam sido iniciados porque a ação policial "desgostou alguns setores do submundo". Por outro lado, o jornal "nanico" Em Tempo, publicou um artigo favorável aos homossexuais, escrito por um dos integrantes do Somos, e a Folha de S. Paulo deu uma cobertura de primeira página ao acontecimento.

Apesar de um momentâneo sucesso em conseguir o encerramento daquela "Operação Limpeza", não se pode dizer que houve uma mudança mais permanente da atitude repressiva da polícia, em relação aos frequentadores das áreas conhecidas como o "gueto homossexual”, mesmo já estando no poder o primeiro governador a ser democraticamente eleito após o golpe militar, Franco Montoro, do PMDB.

4 O Estado de S. Paulo, 1 jul. 1980. 


\section{A política da "fechação"}

Nos relatos acima fica evidente a ambiguidade das frentes de luta em que se envolvem alguns movimentos sociais e, especificamente, as organizações dos homossexuais. Se, por um lado, procuram colocar em questão a ordem social e moral vigente, por outro, ambicionam construir um espaço de legitimidade dentro dessa própria ordem.

Uma das maneiras preferidas, daqueles rotulados como homossexuais, para contestar a ordem vigente tem sido o recurso à velha tradição de "fechação" e desmunhecação, já aproveitadas anteriormente, como vimos, na contestação cultural dos Tropicalistas, Dzi Croquetes, etc. Esse método de atuação, política e satírica, por parte dos militantes homossexuais, é suscetível de várias abordagens, mas, dada a frequência de sua recorrência, não se pode ser ignorado em qualquer abordagem mais aprofundada do tema. Uma das formas interessantes e produtivas de encarar o fenômeno é vê-lo, à maneira de Goffman (1968), como uma tática para lidar com uma identidade estigmatizada.

Como ele nos mostra, o indivíduo estigmatizado, além das outras dificuldades inerentes à sua condição específica, ainda está sujeito a um permanente bombardeio de "conselhos" sobre como se portar e como encarar a sua identidade. Porém, esses conselhos são geralmente contraditórios, enfatizando ao mesmo tempo a necessidade do estigmatizado se integrar na sociedade o melhor possível e a importância dele não tentar negar o seu estigma ou o grupo de estigmatizados ao qual pertence. Dependendo da forma como ele resolve esta charada, o indivíduo será, então, considerado "alienado" ou "autêntico". (GOFFMAN, 1968, p. 135) Mesmo que ele queira ignorar o seu estigma, sempre lhe é cobrado um posicionamento. Portanto, torna-se compreensível, especialmente da parte dos indivíduos mais auto-afirmativos, um comportamento que, ao menos ocasionalmente, enfatize a sua condição de estigmatizado. Outros indivíduos poderão optar por um modo de ação contrário, adotando a prática de camuflagem de sua condição estigmatizada. Mas Goffman (1968) nos chama a atenção para o fato de que, muitas vezes, se espera que o indivíduo se identifique com o agregado de seus companheiros de estigmatização, porque este é considerado o seu grupo verdadeiro, aquele ao qual pertenceria naturalmente. Todas as outras categorias 
ou grupos, aos quais o indivíduo também pertence, necessariamente, não são considerados como realmente seus. Ele não é um deles. Portanto, em termos da sua identidade de ego, ou seja, a forma como ele deveria se avaliar, a condição de "camuflado" pode ser extremamente dolorosa. (GOFFMAN, 1968, p. 139)

Não há como negar também o poder de inquietação desse tipo de comportamento que, em alguns casos, pode provocar reações violentas, como foi o absurdo do arremesso de um grampeador do alto de um edifício sobre os manifestantes. Mas esse desafio a normas, muitas vezes percebidas como naturais, pode também levar indivíduos que convivem com o estigmatizado a colocar em questão suas atitudes preconceituosas. Talvez, o mais importante alvo desse questionamento seja a concepção de que haveria um substrato de "naturalidade" para os padrões de masculinidade e feminilidade. Sontag (1966) escreveu, na década de 60, um artigo seminal Notes on camp que deslanchou toda uma discussão sobre o tema. Lá ela diz que "camp" - um termo difícil de traduzir, mas equivalente, grosso modo, ao nosso "fechação" ou "bichice" - seria uma "sensibilidade", um tipo de esteticismo, uma forma de ver o mundo como um fenômeno estético, mas não em termos de beleza e sim em termos do grau de artifício e estilização. (SONTAG, 1966, p. 275) Esta forma de percepção do mundo seria uma decorrência da condição de oprimido do homossexual, que o levaria a enxergar a natureza artificial de categorias sociais e a arbitrariedade dos padrões de comportamento. A força do camp repousaria, em grande parte, no seu humor corrosivo e iconoclasta, disposto a ridicularizar todos e quaisquer valores. Por exemplo, por ocasião da visita do Papa ao Brasil, nos meios homossexuais, a solenidade da ocasião era frequentemente esvaziada através de referências ao luxo dos "modelitos" envergados por aquele digno personagem, e, ao vê-lo desembarcando do avião, as bichas mais tresloucadas manifestavam séria preocupação de que ele pudesse "quebrar seu salto alto", pondo todo o espetáculo a perder. É nesse sentido que Sontag aponta o camp como sendo um "solvente moral".

Frequentemente, este tipo de "fechação" é criticado por militantes mais "sérios", dos movimentos homossexual e feminista, os quais dizem que, além de ser uma reprodução de estereótipo, ele não levaria 
a nenhuma mudança; seu humor funcionaria mais como uma forma de anestesia. O padrão de masculinidade seria mantido como um ponto fixo, em relação ao qual, as mulheres e os homossexuais masculinos reagiriam, atuando como "aquele que não é masculino".

O que provavelmente mais irrita esses militantes é a falta de seriedade da "fechação", pois, quando todos os valores se tornam objetos de zombaria, nem a própria militância escapa. Mas como Goffman (1968) nos lembra, quando um grupo estigmatizado resolve lutar por direitos, as reivindicações e as estratégias que propõe devem dialogar com o idioma e o sistema de sentimentos correntes na sociedade como um todo.

Seu desdém por uma sociedade que os rejeita só pode ser entendido nos termos em que aquela sociedade concebe o orgulho, a dignidade e a independência. Em outras palavras, a menos que ele possa recorrer a uma cultura estrangeira, quanto mais ele se separa estruturalmente dos normais, mais ele se torna culturalmente parecido com eles. (GOFFMAN, 1968, p. 139)

Como exemplo deste processo, é relevante notar aqui que ocasionalmente os próprios militantes homossexuais têm afirmado que a homossexualidade seria tão saudável quanto outras orientações sexuais, sem se aterem ao fato de que o conceito "saudável" remete à discussão da sexualidade, mais uma vez, ao foro médico-psiquiátrico, que eles tanto rechaçam.

Por ridicularizar todos os valores da sociedade, a "fechação" parece roubar os militantes de pontos de apoio para as suas reivindicações e talvez seja justamente essa a chave para a compreensão do seu poder, que está além da militância social, num nível existencial profundo que nos remete ao aspecto lúdico da existência. Os Dzi Croquetes diziam que não pretendiam ser levados a sério e até afirmavam que o seu público não deveria entender nada. Qualquer proposta específica de novos paradigmas sexuais, por mais "corretos" que aparentem ser, no momento de sua formulação, corre o risco de envelhecer e torna-se tão opressivo quanto a situação anterior. O deboche, por outro lado, ressalta o fato de que, neste campo, tudo, inclusive a militância e seus novos valores, tem seu componente ridículo e absurdo. Serve, 
assim, para combater o surgimento de novos tiranetes, além de ser uma maneira de reafirmar tradições associadas à homossexualidade.

Por outro lado, muitos veem a questão da homossexualidade em termos de direitos civis simplesmente. Mesmo aqueles que gostariam de revolucionar o sistema político e social vigente tendem a reconhecer que certas medidas têm que ser tomadas a curto prazo, para tornar menos perigosas ou incômodas as práticas homossexuais. Portanto, torna-se importante o estabelecimento de um espaço social legítimo para a homossexualidade. Era esse o objetivo do recurso ao apoio parlamentar na campanha contra a violência policial. Confirmando observações de Ruth Cardoso sobre a dinâmica de movimentos sociais, a militância homossexual, após um momento inicial de mobilização quando se identificaram os obstáculos e opositores a partir de um discurso radical, a continuação da campanha levou a contatos com esferas específicas do Poder Público, numa tentativa de manipular suas maneiras distintas e muitas vezes contraditórias de atuação. Como diz a antropóloga, o conjunto de órgãos públicos, apesar de submetido a orientações básicas e comuns, desenvolve políticas parciais, com objetivos diversificados e oferece à população faces bastante diferentes. (CARDOSO, 1983, p. 226) Dessa forma, os próprios contestadores são levados a legitimar o Estado sem, no entanto, conseguir a sua democratização, pois, como nos diz novamente Ruth Cardoso:"Atualmente, o Estado reconhece as associações populares como interlocutores e se torna mais flexível diante de suas demandas. Porém, as finalidades sociais e o controle de sua aplicação escapam, totalmente, ao âmbito de ação dos movimentos sociais". (CARDOSO, 1983, p. 236)

O recrudescimento posterior da perseguição policial aos homossexuais, apesar do seu arrefecimento inicial, parece confirmar amplamente essas observações.

\section{A atuação dos três novos grupos}

Uma vez passada a euforia inicial, após a passeata e a sessão do Conselho Parlamentar de Defesa dos Direitos Humanos, o relacionamento entre os vários fragmentos do antigo grupo entrou em nova fase de deterioração. 
Um grande fator de discórdia foi o Lampião, que também passava por uma fase de desentendimentos internos devidos ao desenvolvimento de um conflito cada vez mais intenso entre os seus "conselheiros" de São Paulo e os do Rio de Janeiro. O jornal passou a se mostrar completamente desencantado com a militância homossexual, atacando todos os grupos, com exceção do Outra Coisa - nome definitivo adotado pela Ação Homossexualista. Seus ataques ao Somos estimularam esse grupo a tentar produzir seu próprio jornal, intitulado O Corpo, mas este nunca conseguiu superar o nível artesanal, com uma periodicidade irregular e uma distribuição precária. Nessa época, todos os jornais alternativos passavam por dificuldades e, depois de um certo tempo, o próprio Lampião deixou de circular.

Apesar da existência de sérias discordâncias entre a maioria dos grupos homossexuais de São Paulo, esses se uniram em diversas ocasiões para protestar contra a violência policial, a violência contra a mulher, para comemorar o aniversário da fundação dos grupos, etc. Houve até uma tentativa de organizar um novo Encontro Brasileiro de Grupos Homossexuais Organizados, incluindo, desta vez, os diversos grupos nordestinos. Mas, as desavenças eram demasiadas e esse encontro nacional acabou sendo cancelado. Em seu lugar, ocorreram o Encontro Paulista dos Grupos Homossexuais Organizados e o Encontro dos Grupos Organizados do Nordeste realizado em abril de 1981, em Olinda.

Refletindo o clima de desentendimento então reinante entre os grupos paulistas, somente o Somos, o GALF, a Facção Homossexual da Convergência Socialista e o coletivo Alegria Alegria, participaram do encontro paulista, realizado também em abril de 1981, na Faculdade de Ciências Sociais da Universidade de São Paulo (USP); os outros grupos paulistas se recusaram a participar.

Nesse encontro, foi decidido que se tentaria promover manifestações no dia 13 de junho para celebrar a passeata e a campanha contra a violência policial realizada no ano anterior. Procurava-se, assim, criar uma data brasileira, equivalente ao 28 de junho, Dia do Orgulho Gay nos EUA, cuja comemoração no Brasil encontrava muita resistência da parte de alguns que consideravam a celebração de uma data americana como um sinal de colonização. 
Foram feitas também uma série de indicações para atuações futuras dos diversos grupos, enfatizando a importância de se procurar uma união maior com outros setores oprimidos, como as mulheres e os negros, a necessidade de se debater a questão homossexual em escolas, sindicatos e outras entidades, sem esquecer a importância do gueto, como um espaço de interação nas lutas contra a repressão, discriminação e a violência em geral. A tônica dessas recomendações era decididamente "militante", mas o comunicado conjunto, emitido no final do encontro, não deixou de ter um final em que se retomava um pouco a velha retórica da "luta pelo prazer":

Finalizando, acreditamos ser importante a realização de encontros regionais e nacional, a fim de que possamos, juntos, encontrar formas de acabar com todas as padronizações que buscam homogeneizar e massificar as ideias, os desejos, o corpo, excluindo o prazer do espelho, o beijo ateu, os seios entre seios, os anseios da cor excluída, transformar, formar e transformar, criando outras formas de idealizar os sentimentos, realizar e novamente desejar os novos seios, os beijos, os olhos, o novo [...].

Apesar desse final, a ênfase maior em militância e na procura de alianças com os outros grupos oprimidos refletiam as alterações ocorridas dentro do Somos, depois da saída da maioria dos "veteranos", defensores das antigas ideias "anarquistas". Depois da divisão do Somos, os integrantes mais próximos das organizações marxistas pareciam ser, durante certo tempo, quase os únicos com ideias políticas mais elaboradas para apresentar aos que permaneceram no grupo. Embora ainda restassem alguns simpatizantes das antigas posições, o clima de animosidade que se criou entre o Somos e o Outra Coisa tornou mais fácil a manutenção de posicionamentos "socialistas", uma vez que tudo que se era associado aos "veteranos" passou a ser rejeitado.

Símbolo da discordância entre os defensores das posições tradicionais e os "marxistas" foi a discussão que se travou a respeito da forma de tratamento a ser usada dentro do grupo. Alguns "marxistas" propunham o uso do termo "companheiro", tradicional na esquerda, enquanto seus opositores se posicionavam contra esse termo, por temer que causasse confusão entre a luta homossexual e a de classe. A discussão se tornou mais confusa quando alguns passaram a concebê-la como um confronto entre as palavras "companheiro" e 
"bicha". Como já se explicou, este último vocábulo não era normalmente usado como forma de tratamento, mas, sim, como forma de designação dos homossexuais masculinos e sempre causara um certo mal-estar entre muitos dos integrantes recém-ingressos no grupo, que não se acostumavam ao seu uso não-pejorativo. Portanto, havia uma tendência a rejeitá-lo, especialmente devido ao seu frequente uso pelo jornal Lampião, muito identificado com os que formaram o Outra Coisa. Dentro do clima de animosidade que passou a reinar no Somos, aquelas palavras começaram a ser usadas como armas e alguns "socialistas" ocasionalmente até chamavam os que defendiam as posições "anarquistas" pela palavra "companheiro" para provocá-los. Finalmente, em uma reunião de reestruturação do grupo, realizada em agosto de 1980, ficou decidido que qualquer forma de tratamento poderia ser usada dentro do grupo, contanto que existisse consentimento entre as partes envolvidas.

Em outra discussão a respeito dos propósitos do Somos, os "anarquistas" defendiam a "luta contra o nosso machismo e o nosso autoritarismo", enquanto os "socialistas" criticavam esses termos, por serem muito imprecisos e conducentes à rejeição de qualquer tipo de organização, pois esta ficaria sempre exposta a equiparações vagas com "machismo" ou "autoritarismo". Em agosto de 1980, foi redigida e aprovada uma carta de princípios do Somos, na qual as posições "anarquistas" eram bastante relegadas em favor de uma maior ênfase para as ideias "socialistas". A própria existência de uma carta como essa já era uma novidade e um questionamento da aparente abertura total a que o Somos anteriormente dizia se propor, embora nunca a tivesse alcançado plenamente.

Curiosamente, apesar da nova liderança impor certas mudanças no discurso oficial do grupo - não se falava mais em "autoritarismo" ou na aliança entre política e prazer -, a nova carta mantinha certas concepções tradicionais do Somos, apesar delas nunca terem funcionado na prática. O grupo continuava a ser dotado formalmente de um número demasiado de subgrupos com diferentes atribuições, além de se insistir na ideia de uma rotatividade dos coordenadores. Como tinha ocorrido em tantas tentativas prévias de reestruturações, o Somos continuou sob a liderança de um subgrupo formado pelos 
"mais interessados", o único a ter um funcionamento mais regular, além de alguns novos subgrupos de reconhecimento que, na prática, eram quase autônomos e tinham vida efêmera. Isso indica o quanto o Somos ainda acreditava na sua vocação aglutinadora para todos os "homossexuais conscientes", que continuavam a ser percebidos como uma categoria única e homogênea.

Apesar de todas as mudanças, o grupo continuou a sofrer desavenças internas e, aos poucos, os antigos militantes, tanto "anarquistas" quanto "socialistas", começaram a deixar o Somos. Uma nova liderança foi estabelecida e alugou-se uma sala, num velho prédio na Rua Abolição, 244, no Baixo da Bela Vista, perto do centro da cidade. Nessa nova sede, foram promovidas inúmeras atividades, visando o contato com os outros grupos engajados na "luta geral" e nas "lutas minoritárias". Também se procurou desenvolver laços com o gueto, através da realização de festas, debates e da criação de um cineclube. Mas, o desenvolvimento acentuado do comércio voltado ao público gay tornava o Somos pouco atraente para aqueles interessados principalmente nas possibilidades de sociabilidade oferecidas pelo grupo. Durante esse tempo, o nível socioeconômico médio dos participantes caiu sensivelmente e o seu principal atrativo, em comparação com os novos bares, discotecas, saunas, etc., parecia ser o baixo custo de frequentá-lo. Politicamente, o Somos procurou manter-se ativo, participando dos debates da campanha eleitoral de 1982 e da campanha promovida pelo Grupo Gay da Bahia contra a classificação da homossexualidade como "desvio e transtorno sexual", adotada pelo INAMPS. Finalmente, em 1983, problemas financeiros e a dificuldade em conseguir novos membros levaram o grupo a abandonar sua sede e a se dissolver.

Já o grupo de dissidentes, que adotara o nome Outra Coisa - Ação Homossexual, buscou evitar o que considerava um ativismo demasiadamente intenso e, após fazer algumas exortações a antigos integrantes do Somos para que se juntassem a eles, resolveu se fechar, deixando de aceitar novos membros. Inicialmente, grande parte de suas energias se voltaram para um ataque constante contra o Somos, acusando-o de estar "atrelado" completamente à Convergência Socialista. Levantando a bandeira da "autonomia", uniram-se aos grupos 
Eros e Libertos, para combater a hegemonia do Somos dentro do movimento homossexual paulista. Logo, porém, essa aliança começou a se desfazer, surgindo inúmeras desavenças entre os três grupos. O Outra Coisa participou ativamente da série de campanhas, posicionando-se contra a violência policial, pela discussão da questão homossexual durante as eleições de 1982 e atuando na divulgação de informações a respeito da aids, por exemplo. Também alugaram um local para sua sede, compartilhado durante algum tempo com o GALF. Suas atividades receberam considerável cobertura da imprensa, mas foram dadas por encerradas em 1984, devido à perda de interesse por parte de seus militantes e às dificuldades em pagar o aluguel de sua sede.

Dos três grupos, o único que sobrevivia até $1988^{5}$ foi o grupo de Ação Lésbica-Feminista, o GALF, que, após a divisão, voltou suas atenções para os outros grupos feministas e para o gueto lésbico. Sua atuação foi importante em levar o movimento feminista a dar mais atenção à questão da sexualidade feminina e ao lesbianismo, em específico. Esse foi um importante ponto de atrito entre o GALF e outros grupos feministas, especialmente o SOS Mulher, acusado de não assumir o lesbianismo praticado por muitas de suas militantes. (PONTES, 1986)

O GALF também sofreu uma série de conflitos internos e, pouco depois de sua formação, ocorreu uma dissidência de mulheres que saíram para formar outro grupo, de curta duração, chamado Grupo Terra Maria.

As atividades do grupo foram bastante intensas, ora voltadas para o movimento feminista, ora para o gueto lésbico. O boletim Chanacomchana $^{6}$ era editado esporadicamente e usado como veículo para uma maior aproximação com outras mulheres. Nele estão espelhadas algumas mudanças importantes nas concepções iniciais das militantes do GALF sobre a reprodução de papéis sexuais entre as lésbicas. Passaram a dar uma importância muito maior para a fantasia sexual e a admitir que a "linguagem erótica" não era necessariamente uma manifestação da reprodução dos papéis sexuais. Como diz Rosely

5 Data da redação original deste livro.

6 Em 1987 na busca de um público maior, o nome do boletim foi mudado para Um outro olhar. 
Roth, uma de suas principais militantes: “Às vezes, esta linguagem erótica (roupas, gestos, maneira de se comportar na cama) é produto da fantasia sexual e, como acredito que não podemos e nem devemos padronizar as fantasias, o importante é que não se reproduza a relação de dominação".

Em 1988, o GALF se encontrava sem sede e o número de integrantes era flutuante, mas suas atividades continuavam e suas militantes eram as únicas a se mostrarem dispostas a organizar eventos políticos declaradamente voltados à questão lésbica.

Embora o movimento homossexual brasileiro tenha entrado em sério declínio, restando pouquíssimos grupos em atividade, subsistem redes de amizades e de comunicação criados a partir deles ${ }^{7}$. Poucos antigos militantes manifestaram disposição para qualquer volta à atuação nos moldes anteriores. Porém, em certos momentos críticos, os membros de diversos grupos extintos têm se reunido para discutir e tentar efetuar algum tipo de mobilização da população que se identifica como homossexual. Em três ocasiões, por exemplo, formaram uma comissão para protestar contra a violência policial junto ao Secretário de Segurança do Estado e foi um grupo deles quem, em primeiro lugar, alertou as autoridades sanitárias paulistas a respeito do perigo da Síndrome de Imunodeficiência Adquirida (AIDS), dando ensejo a uma atuação, nesse campo, pioneira no Brasil por parte das autoridades médicas paulistas. (SILVA, 1986, p. 3-23)

7 Esta situação percebida pelo autor em 1988, viria a se modificar com o passar do tempo. Atualmente o Movimento Homossexual está muito desenvolvido e visivel em todo o país, especialmente durante as Paradas LGBTI. 


\section{Dupla discriminação e dupla militância, o caso das lésbicas e dos negros dentro do movimento homossexual}

O movimento homossexual, como vimos, surge no seio de uma contestação mais ampla dos valores de uma sociedade tida como “autoritária”. Os alvos dessa contestação são, não só as estruturas opressivas estabelecidas pela ditadura pós 1964, mas também aquelas que se consolidaram na oposição tradicional. Contra a ideia de hierarquia, de "centralismo democrático" e da liderança dos "mais conscientes" surgiu a noção da comunidade dos iguais, na qual uma opressão em comum é vista como obliterando todas as heterogeneidades de classe, idade, nível cultural, biografia, etc. Embora nutrindo inúmeras divergências em seu seio, surge um aglomerado de movimentos de cunho marcadamente libertário, que adotam o rótulo genérico de "minorias" e se contrapõem à política oposicionista tradicional, assentada no conceito central de luta de classes. Inicialmente rechaçados, tanto pela direita, quanto pela esquerda, eles procuram apoio e legitimação em outros movimentos similares. No caso do Somos, já vimos como sua 
primeira apresentação pública se deu no contexto de uma Semana das Minorias na Universidade de São Paulo (USP) e sua primeira manifestação nas ruas no bojo de uma passeata para marcar o Dia de Zumbi, promovida pelo movimento negro.

Porém, se, por um lado, essas alianças trazem força e legitimidade, por outro, elas também levam à validação de certas heterogeneidades internas aos vários movimentos, ameaçando a sua autorrepresentação como "comunidades de iguais". Assim, ao se aliar às feministas ou aos militantes negros, o movimento homossexual não pode deixar de reconhecer as diferenças entre homossexuais femininos e masculinos ou o racismo em seu seio. Os outros movimentos também sofrem efeitos similares e as feministas são instadas a reconhecer as especificidades das mulheres negras ou lésbicas, da mesma forma que os militantes negros são forçados a aceitar a existência de diferenças entre negros e negras e entre seus companheiros heterossexuais e homossexuais. Surge assim o personagem que se diz "duplamente discriminado" e que, portanto, reivindica o direito à dupla militância, normalmente vista com muita suspeita dentro desses grupos. Com certa relutância, ele geralmente acaba sendo aceito, pois se fundamenta na lógica de todos os movimentos "minoritários". Muito mais difícil, porém, é a conciliação com uma "dupla militância" que envolva, além do "grupo minoritário", a participação em organizações voltadas à política partidária mais ampla, sobre as quais sempre pesa a suspeita de desejarem minar a autonomia desses movimentos.

Neste capítulo, procurarei examinar em mais detalhe a atuação de dois grupos "duplamente discriminados": o das lésbicas e o dos negros homossexuais. Em ambos os casos, lanço mão de material de pesquisa mais indireto, baseando-me, em grande parte, em depoimentos e textos produzidos por esses militantes, ressaltando aqueles aspectos mais diretamente relevantes ao movimento homossexual. Com essa ressalva, desejo deixar claro que não vejo minhas considerações nesses assuntos como sendo, de nenhuma forma, um trabalho definitivo. Este deveria ser, a meu ver, feito por pessoas que tenham tido vivência mais concretas desses grupos. 


\section{A constituição do GALF, um grupo exclusivamente lésbico}

Entre grande parte da população, a palavra "homossexual", às vezes causa uma certa confusão. Apesar de existirem outras interpretações possíveis para as intenções iniciais de Benkert, ao inventar esse termo, a maioria das pessoas cultas que o empregam acreditam que seu significado esteja expresso na composição híbrida de um prefixo de origem grega (homo=igual) e uma raiz latina (sexual), significando "sexo igual" ou "sexo com igual". Porém muitos interpretam a palavra de maneira diferente, acreditando que o prefixo "homo" venha do latim e que o termo signifique algo como "sexo de homem". Em alguns casos a palavra adquire até uma versão popular e vira "homem-sexual".

De qualquer modo, é importante lembrar de que a palavra "homossexual" tem um certo cunho erudito e só se incorporou aos poucos à linguagem cotidiana, assim como só recentemente o assunto passou a ser considerado de "bom tom" em círculos que se dispõem a discutir questões "sérias". Até há pouco, o tema era raramente levantado, exceto em grupos quase exclusivamente masculinos, que o tratavam na base da galhofa, empregando, nesse caso, termos considerados chulos como: "viado", "bicha", "sapatão", etc. Nesses casos, é corriqueiramente feita a distinção entre homossexuais masculinos e femininos. Essa distinção parece ter bases muito antigas, e, até recentemente, embora a prática homossexual masculina pudesse vir a ser discutida, o lesbianismo era quase totalmente ignorado. A própria atividade científica, que no começo deste século se empenhava em classificar todos os fenômenos sociais, deixou de se ocupar muito do assunto. Em 1901, Kraft-Ebbing escreveu que somente existiam cinquenta casos do fenômeno e até hoje o lesbianismo continua a ser menos estudado do que a homossexualidade masculina. As próprias maneiras em que se reprimiam essas práticas comprovam as diferenças entre as formas como eram concebidas as homossexualidades nos dois gêneros. Embora a homossexualidade masculina fosse geralmente perseguida e até criminalizada, o lesbianismo comumente ficava livre de sanções jurídicas, sendo frequentemente ignorado pelas legislações. (WEEKS, 
1977, p. 88) Uma vez que os papéis de gênero eram concebidos como tendo bases biológicas, até as etiologias propostas para a homossexualidade eram diferentes nos dois casos.

A identidade dessas duas homossexualidades parece ser, em grande parte, resultado da atual hostilidade que a sociedade geralmente lhes dedica e do fato de que, em alguns dos lugares onde homossexuais masculinos se reúnem, o clima generalizado de questionamento das normas sexuais fornece um certo respaldo também ao lesbianismo. Mas, essa convivência entre homossexuais dos dois sexos nem sempre é pacífica e é comum a homossexualidade ser acompanhada de misoginia ou misandria.

Tanto nos EUA quanto na Europa, os movimentos homossexuais têm sido forçados a reconhecer que não se pode ver a lésbica como simples equivalente feminina dos homossexuais masculinos. Na Inglaterra, por exemplo, a estudiosa do assunto, A. Faraday, alerta para os perigos de se deixar de apreciar o contexto da opressão genérica sofrida pelas mulheres, sejam elas homossexuais ou não, e sugere que uma abordagem mais interessante para o tema deveria questionar a natureza dos rótulos e de seus efeitos estigmatizantes, através de um enfoque nas origens e funções do rótulo, sem deixar de afirmar a natureza positiva e política da identidade lésbica. (FARADAY, 1981, p. 112)

No movimento homossexual brasileiro, vários grupos começaram com integrantes masculinos e femininos, talvez devido à força da categorização "homossexual", igualmente aplicado a homens e mulheres. Além disso, a magnitude da estigmatização que sofriam os levava a procurar somar suas forças ao máximo em sua busca de reconhecimento social e político. Porém, logo surgiram divergências, consequências naturais das diferentes posições sociais ocupadas pelos dois sexos. Além disso, depois de certo tempo, o movimento homossexual conseguiu um grau de respeitabilidade política entre diversos setores progressistas, especialmente no movimento feminista, que aprendeu a encarar de forma mais positiva a questão. Deixou de lado o empenho em afirmar constantemente a condição heterossexual de suas militantes, frequentemente rotuladas como "sapatões", simplesmente por contestarem os aspectos mais opressivos dos papéis de gênero tradicionais. Uma vez vencido o receio original das feministas de se 
associarem com as lésbicas, estas começaram a se identificar muito mais com as mulheres militantes do que com os homossexuais organizados masculinos. É esta trajetória das mulheres dentro do Somos, que proponho retratar aqui, deixando para outro/a estudioso/a do assunto discussões mais profundas de todas as implicações associadas à ideia de uma "identidade lésbica".

\section{Os primeiros tempos: homens e mulheres indiferenciados dentro do Somos}

Durante o seu primeiro ano de existência, em 1978, o embrião do futuro grupo não foi bem sucedido em atrair mulheres. Estas, porém, começaram a frequentar as reuniões do grupo depois de sua apresentação no debate da Universidade de São Paulo (USP), no começo do ano seguinte, e, em março, dos vinte e cinco integrantes do grupo, dez já eram mulheres. Discutia-se, então, a melhor forma do grupo lidar com o repentino aumento dos seus números, pois o grupo de identificação tornara-se demasiadamente grande para funcionar adequadamente.

Como já vimos, a solução encontrada foi formar três grupos menores, que possibilitassem a participação efetiva de todos os integrantes. Achava-se, na época, que seria interessante que todos esses subgrupos tivessem mulheres, que dessem uma contribuição lésbica para as suas discussões. Desta forma, as mulheres, que já eram minoria dentro do Somos, foram dispersadas, mas, na ocasião, todos os presentes, as mulheres inclusive, concordaram com essa ideia. Esse sistema foi adotado durante aproximadamente dez semanas, mas desde o início já demonstrava não satisfazer aos anseios de muitas das suas participantes.

Por volta de abril daquele ano, o Lampião encomendou um artigo sobre lesbianismo, a ser escrito por mulheres do Somos, do Eros e por algumas outras que não participavam de nenhum grupo homossexual organizado. Reuniram-se aproximadamente vinte e cinco mulheres, das quais dez tiveram uma participação mais intensa. Contando com a assessoria de uma jornalista, redigiram uma série de artigos que foram publicados no Lampião, de maio de 1979. Essa edição teve uma 
repercussão muito favorável no meio homossexual, graças, em parte, ao esforço das mulheres, que saíram vendendo os jornais nos bares e boates que formam o gueto lésbico.

Houve, porém, uma certa insatisfação por parte das autoras do artigo, pois um trecho em que elas explicavam mais detalhadamente o seu comportamento sexual havia sido omitido no jornal. Aguinaldo Silva, coordenador da edição, havia tomado essa decisão por recear que o jornal pudesse sofrer algum tipo de processo judicial por pornografia. Isso causou uma certa indignação, não só entre as mulheres mas também entre os homens do Somos, já que, por razões de tempo, as autoras não haviam sido consultadas sobre esse corte. $\mathrm{O}$ assunto chegou mesmo a ser levantado numa reunião de pauta do Lampião realizada em São Paulo, na qual participaram vários integrantes do Somos e onde os ânimos ficaram bastante exaltados.

Embora cerca de vinte e cinco mulheres houvessem se proposto a trabalhar no artigo, somente dez foram até o fim. Esse coletivo de mulheres não conseguiu se manter por muito tempo, impossibilitando a reunião de avaliação da experiência em que algumas mulheres esperavam que se formasse o embrião de uma atuação mais permanente. Algum tempo depois, essa reunião acabou sendo realizada por um grupo de mulheres bastante reduzido, e uma das conclusões a que se chegou foi de que elas haviam dado demasiada ênfase à matéria jornalística e perdido uma oportunidade de formar uma organização lésbica.

Foi a partir daí que as mulheres passaram a reivindicar a criação, dentro do Somos, de um subgrupo exclusivamente feminino. Nisso, encontraram apoio por parte de alguns homens, que já tinham uma certa familiaridade com as concepções feministas. Apesar das posições de influência desses homens no grupo, outros criticaram a proposta, alegando que era "divisionista" e lamentando a perda de um contato tão novo e valioso com lésbicas, até então vistas por alguns como seres totalmente desconhecidos. Algumas das mulheres também se colocavam contra essa ideia, vista como a tentativa de uma "cúpula" estabelecer sua hegemonia sobre as demais.

A partir de uma reunião geral, realizada em 2 de junho de 1979, foi formalizada a constituição de um subgrupo só de mulheres e que 
passou a ser chamado Lésbico-Feminista ou, mais simplesmente, LF. Nem todas as integrantes do Somos aderiram a ele e algumas continuaram a participar de subgrupos mistos, durante mais algum tempo, até, finalmente, deixarem o Somos.

Tendo finalmente conquistado o direito de se reunirem em separado, as lésbicas inicialmente se sentiram um pouco desnorteadas. Como todas já haviam participado de grupos de identificação, sentiam a necessidade de se engajar em outras atividades. Tentaram retomar a ideia de escrever sobre lesbianismo para o Lampião, mas, como nenhuma delas tinha muita prática de escrever, a ideia foi abandonada. Porém, antes, elaboraram um roteiro lésbico de São Paulo, a partir de entrevistas realizadas entre si sobre locais abertos às mulheres homossexuais.

Começou, então, um período de crise severa no grupo de mulheres, que foi se esvaziando gradativamente até restarem somente quatro militantes. Três dessas haviam sido as mais ardorosas defensoras da ideia de um grupo autônomo de mulheres e continuavam muito identificadas com ela. Nessa época, o grupo continuou a receber algumas integrantes novas que certas vezes chegavam com propostas de ação, mas suas passagens pelo grupo eram breves, e somente as quatro, cujo contato com o Somos vinha desde o começo do ano, permaneciam.

Essas quatro mulheres diziam se sentir muito isoladas e temiam que seu grupo virasse apenas um "clube de chá". Embora elas contassem com o apoio de alguns homens do grupo, achavam necessário mostrar que eram capazes de caminhar sozinhas e fazer um serviço proveitoso. Apesar de não costumarem frequentar o gueto lésbico de São Paulo, resolveram voltar suas atenções a ele, com a finalidade de tentar "conscientizar" suas frequentadoras.

Uma de suas atividades nesse sentido foi a distribuição e venda dos números do Lampião com artigos sobre mulheres. Com esse trabalho, elas conseguiram se tornar conhecidas por um grande número de lésbicas que, embora não estivessem dispostas a participar do grupo, davam apoio a seu trabalho na rua. Também tentaram fazer um questionário sobre as atividades e necessidades das lésbicas do gueto. Essa pesquisa, embora iniciada, nunca foi levada a término. Outra atividade, talvez a de maior êxito a que se propuseram, era dar 
resposta a cartas que eram endereçadas à Caixa Postal do Somos, o que servia como forma de tentar recrutar novas militantes.

Entre agosto e outubro de 1979, o LF, juntamente com o resto do Somos, parecia passar por uma séria crise. Chegou-se até a dizer que o subgrupo lésbico não existia mais. A situação só melhorou quando algumas das mulheres foram convidadas a participar da Semana Feminista de Campinas e da organização do Encontro Nacional de Homossexuais, promovido inicialmente pelo Lampião. Outra atividade que as estimulou foi a sua participação no II Congresso da Mulher Paulista.

\section{O II Congresso da Mulher Paulista ${ }^{1}$}

Inicialmente, a inclusão das lésbicas na comissão de preparação do II CMP não foi aceita tranquilamente pelas organizações envolvidas. Várias delas, mesmo as que se rotulavam como feministas, expressaram veladamente o receio de que sua inclusão poderia afugentar as mulheres da periferia, que ainda seriam muito preconceituosas. Essa foi, talvez, a primeira ocasião em que as lésbicas se viram enfrentando preconceitos de heterossexuais sem contar com um apoio de retaguarda dos homens do Somos. O grupo insistiu em afirmar a sua natureza lésbica e até chegou a comparecer a uma reunião de representantes de vários grupos feministas para exigir satisfações. As mulheres heterossexuais negaram que estivessem agindo com preconceito e a questão foi deixada de lado.

Representantes do grupo lésbico, que já começava a ser conhecido como "LF", participaram das reuniões de preparação do Congresso, de dezembro 1979 até começo de fevereiro1980. Durante essa época, elas ainda sentiam bastante insegurança e falavam pouco nas reuniões, dizendo preferir conquistar um espaço através de trabalho prestado. A postura que adotaram era de que eram lésbicas, nunca haviam trabalhado com outro grupo de mulheres e que estavam ali para aprender. Por causar menos controvérsia, elas usavam mais o nome Somos do que o Lésbico-feminista.

1 Para outra descrição detalhada deste evento. (PONTES, 1986, p. 59) 
O II CMP, realizado no Teatro da Pontifícia Universidade Católica de São Paulo, nos dias 8 e 9 de março de 1980, foi uma experiência nova e bastante traumatizante, não só para as lésbicas, mas também para as outras feministas e os homossexuais masculinos que dele participaram.

O Somos não havia estado presente no I CMP, realizado no ano anterior, organizado por nove entidades e que, no seu auge, contara com aproximadamente 500 participantes. O II Congresso, refletindo o aumento do interesse despertado pelo movimento de mulheres, mostrou um crescimento gigantesco - teve três mil participantes - o que levou a uma alteração em sua composição e atuação. A coordenadoria para o congresso de 1980 passou a contar com a colaboração de 53 entidades, incluindo nove sindicatos e um grande número de "organizações fantasmas" que serviam como instrumento de manipulação partidária.

Organizações ligadas a partidos políticos inundaram o congresso com mulheres e seus filhos trazidos em ônibus dos bairros da periferia. As entidades feministas, que de fato haviam organizado o encontro, se acharam em posição minoritária. Assim, tiveram muita dificuldade em levar a diante as discussões que desejavam sobre problemas específicos da mulher, como, por exemplo, uma campanha pelo aborto. O tema do congresso: "Violência contra a mulher", acabou sendo bastante escamoteado, em favor da tese de que a violência básica da sociedade era a da ditadura, exercida contra os homens e mulheres da classe operária. Setores do PMDB, identificados como integrantes do grupo MR8 - Movimento Revolucionário 8 de Outubro, chegaram mesmo a repudiar a existência do Congresso das Mulheres, por achá-lo divisionista na luta maior contra a ditadura. Levavam a palavra de ordem "Unidade", e tanto fizeram para tumultuar o segundo dia de trabalho que conseguiram bloquear as discussões e dissolver o congresso. Este só viria a ser oficialmente encerrado alguns dias mais tarde, apenas com a presença das coordenadoras do evento. $\mathrm{O}$ clima das discussões era, portanto, bastante tenso, em meio a conchavos, manobras e palavras de ordem. Várias vezes, entidades contrárias a uma organização independente de mulheres adotaram a tática de tomar o tempo das discussões com longos discursos inflamados e demagógicos sem maior substância prática. A certa altura houve até 
recurso à violência física, quando partidárias daquela facção do PMDB atacaram a mesa de trabalhos.

As representantes do Somos eram aproximadamente treze mas, sem nenhuma experiência de participação em reuniões como essa, tiveram dificuldades em se fazer ouvir e em expor suas reivindicações. No primeiro dia de debates, elas se reuniram em um só subgrupo de discussões, no qual formaram maioria. Mas, como haviam diversos grupos, seu efeito foi limitado. No segundo dia, elas mudaram de tática e se espalharam por mais grupos, procurando dar maior divulgação às suas ideias.

Apesar das frustrações, a experiência lhes foi muito proveitosa. Puderam entender melhor as formas de atuação de diversos grupos de esquerda, travaram um diálogo mais intenso com as feministas heterossexuais e tiveram um primeiro contato com donas de casa de periferia. Estas, embora escandalizadas pelas posições das lésbicas e sua ênfase na sexualidade feminina, ouviam suas colocações com "indignação controlada" - como disse uma das lésbicas participantes. Já as reações de agressividade quase histérica vinham de mulheres que falavam em nome de instituições que se diziam populares, como o PMDB e os sindicatos - apelidados por uma das lésbicas participantes de "cães de guarda do proletariado".

Embora se tratasse de um Congresso de Mulheres, homens que estivessem dispostos a apoiá-lo foram convidados a ajudar a tomar conta das crianças nas creches especialmente montadas e a fazer outros serviços de infraestrutura. Além dessas atividades, eles puderam também participar de um grupo masculino de debates sobre a mulher. Apesar do relacionamento entre os homens e as mulheres do Somos estar um tanto abalado, na época, devido à tendência cada vez mais autonomista das lésbicas, que criticavam o que diziam ser o comportamento machista dos homens homossexuais, vários destes participaram do congresso. Como eram relativamente poucos os homens heterossexuais presentes, os homossexuais formaram uma parcela relativamente considerável do grupo de discussões masculinas e foram os principais responsáveis pelo teor bastante feminista dessas discussões, retomado no documento final elaborado por esse grupo masculino. De fato, muitas das feministas afirmaram depois que esse 
documento era o mais progressista a sair da reunião, pois falava da necessidade de se lutar pela legalização do aborto, do direito da mulher à satisfação sexual, incluindo a homossexual, da divisão do trabalho doméstico, das lutas por salário igual, por trabalho igual, por creches, lavanderias coletivas e participação da mulher na vida política.

João Silvério Trevisan, escrevendo sobre esse congresso para o Lampião, expressou os sentimentos de grande parte dos integrantes do Somos que haviam participado dele:

Se teve lances amargos, foi por isso mesmo que o Congresso acabou sendo um marco importante para as mulheres. As feministas, negras, lésbicas (e eu incluiria as bichas) puderam sedimentar uma ideia que germinava com alguma timidez: nossas lutas são autônomas e serão empreendidas em paridade, sem abrir mão daquilo que nós achamos que é bom para nós e sem subserviência a uma suposta luta maior, prioritária. Nós proclamamos o que parece prioritário para nós. Graças a esse Congresso, também já podemos ter uma prévia do que nos espera: fatalmente o sistema estará tentando cada vez mais recuperar (ou digerir ou absorver) estas nossas formas alternativas de práxis política, para seu próprio usufruto. E Sistema é tudo o que foi institucionalizado, seja à direita ou à esquerda - porque a esquerda já está gozando de sua parcela de poder, dentro das estruturas atuais. ${ }^{2}$

É importante ressaltar o impacto dessas colocações de Trevisan, dada a influência que o Lampião exercia naquela época sobre as ideias dos homossexuais no país inteiro. Os grupos homossexuais que haviam participado do Congresso também produziram um documento, reiterando seu apoio à luta específica das mulheres contra a discriminação sexual e a dupla jornada de trabalho, em defesa da equiparação salarial, da criação de creches, da legalização do aborto gratuito e do direito à sua utilização. Também repudiaram a interferência dos partidos políticos no congresso, acusando-os de tentarem "esvaziar o conteúdo da luta específica das mulheres" escamoteando a discussão de temas como: o machismo, a questão lésbica, as opressões sofridas

2 Lampião, p. 7, abr. 1980. 
pelas mulheres negras, pelas presas comuns, pelas prostitutas e a necessidade da legalização do aborto.

No final desse congresso, estava armado o cenário que iria levar a dois acontecimentos traumatizantes no movimento homossexual de São Paulo: o desligamento formal e final do LF do Somos e o racha entre os homens do grupo. Antes, porém, ocorreu o I Encontro de Grupos Homossexuais Organizados (EGHO), no qual as integrantes do LF tiveram atuação destacada e a discussão de temas ligados à homossexualidade feminina foi considerada muito importante, atraindo um grande número de interessados.

As discussões do EGHO também se dirigiram à questão da diferença numérica entre homens e mulheres nos grupos homossexuais e, neste ponto, foram revelados interessantes detalhes sobre a composição numérica dos diversos grupos: Auê-RJ, 35 homens e 5 mulheres, Somos-RJ, 60 homens e 8 mulheres, Somos-SP, 80 homens e Ação Lésbica Feminista - o único a ser um grupo exclusivamente composto por mulheres com 20 componentes - Eros-SP, 5 mulheres e 11 homens, Fração Gay da Convergência Socialista, 7 homens e 3 mulheres, Beijo Livre-Brasília, sem nenhuma mulher.

Como tônica principal desses debates, ficou confirmada a ideia de que a lésbica era "duplamente discriminada", enquanto mulher e enquanto homossexual, e que a solução para ela "não é o gueto, nem a clandestinidade, mas a organização através da criação de um movimento transformador e libertário".

Além da atuação marcante durante os debates sobre as questões lésbicas, as integrantes do LF também tiveram uma participação de destaque na comissão de segurança, constituída para impedir a entrada de participantes não inscritos, na parte fechada ao público, e dos meios de comunicação, na parte aberta. Distribuíram também um histórico do seu grupo com uma lista das suas atividades, assim como indicações sobre as maneiras de se começar um grupo feminista, discussões sobre alguns temas polêmicos, propostas de temário para grupos de reconhecimento de mulheres, um manifesto sobre mulheres violentadas, documentação sobre o II Congresso da Mulher Paulista e uma bibliografia feminista. Além disso, distribuíram também um panfleto em que declaravam sua disponibilidade para trabalhar com 
todas as mulheres organizadas em grupos homossexuais ou interessadas nas questões, buscando unificar, "visando, posteriormente, a massificação" do movimento, bem como se solidarizando com os demais contingentes oprimidos e discriminados da nossa sociedade".

\section{As comemorações do 19 de maio e o "racha"}

Como já vimos, uma das discussões mais polêmicas do Encontro foi sobre a participação dos homossexuais nas comemorações sindicalistas de 19 de maio de 1980. Essa questão polarizava violentamente os adeptos das ideias "anarquistas/autonomistas" de um lado, e os simpatizantes do marxismo, do outro. As integrantes do LF optaram por seguir as resoluções da coordenadoria do II Congresso da Mulher Paulista, favorável ao comparecimento das feministas às comemorações. As integrantes do LF começaram, assim, a manipular a sua dupla identidade (mulheres e homossexuais) inaugurando uma estratégia que seria repetida em outras ocasiões. Mais do que se sentir "obrigadas" por compromissos assumidos com as feministas, possivelmente a motivação de algumas líderes do LF fosse relacionada à política interna do Somos e até à convicção de que os homossexuais deveriam mesmo ir às comemorações operárias. Posteriormente, algumas delas reconheceram que invocar um compromisso com as outras feministas fora um pretexto convincente, pois, como mulheres assalariadas, achavam que tinham a obrigação de participar. Mas esse sentimento não foi unânime. Muitas expressaram grande receio da repressão física que poderia vir, tanto das forças policiais, como de "machões" operários indignados com seu lesbianismo declarado. Esse temor de uma possível repressão vindo da parte de trabalhadores machistas também foi manifestado por um grande número de homens homossexuais.

Até a véspera do 19 de maio, as integrantes do LF não haviam realmente decidido se participariam ou não, temerosas de violência, por parte da polícia e de trabalhadores. O que as levou, finalmente, a comparecer foram algumas iniciativas individuais, como a chegada, na manhã de 19 de maio, de uma delas na casa onde estavam dormindo várias integrantes do grupo. Ela estava determinada a ir e foi chamar 
as amigas que estavam quase desistindo da ideia. O seu entusiasmo serviu para despertar o ânimo das outras e logo todas se dirigiram para São Bernardo. Ao chegarem lá, encontraram-se como outras que, espontaneamente, também haviam resolvido comparecer. Longe de sofrer a repressão que esperavam, elas não foram molestadas nem pela polícia e nem pelos outros participantes da manifestação. Muito pelo contrário, foram ovacionadas quando entraram no estádio junto com os homens homossexuais, portando uma faixa que dizia: "Comissão de Homossexuais pró-19 de maio".

A experiência foi muito encorajadora, mas consequências desagradáveis não tardaram a vir. Durante algumas semanas, o grupo ficou seriamente abalado com o aparecimento de uma divisão irreconciliável entre duas facções masculinas: os que foram ou apoiaram o comparecimento à Vila Euclides e os que foram a um piquenique que havia sido organizado como evento alternativo. Houve duas reuniões gerais convocadas para "lavar a roupa suja" do grupo, às quais as mulheres compareceram e nas quais elas foram acusadas, por alguns homens, de estar compactuando com a infiltração do grupo pela Convergência Socialista. Os ânimos estavam exaltadíssimos durante esses dias e era difícil se formar uma ideia clara sobre o que estava acontecendo de fato. As integrantes do LF, que já estavam distanciadas das discussões e atividades dos homens há algum tempo, começaram a declarar que o clima tornava impossível qualquer trabalho com eles.

Houve uma reunião do LF, chamada para decidir sobre a posição do grupo a ser adotada na reunião geral do Somos, marcada para o dia 17 de maio. Todas as integrantes do LF, menos duas, participaram dessa reunião preparatória na qual, mais uma vez, discutiu-se se valeria ou não a pena às lésbicas continuarem como uma facção dentro do Somos. Todas apresentaram suas posições e a decisão foi unânime contra a permanência.

No dia da reunião geral do Somos, tanto as mulheres, quanto os homens foram surpreendidos pelo manifesto lido no início, no qual o grupo que denunciava a atuação de elementos ligados à Convergência Socialista, criticando também a participação dos homossexuais no ato público de Vila Euclides, anunciava o seu desligamento do Somos. 
A posição das integrantes do LF era diferente desta; elas desejavam sair principalmente por acharem impossível um grupo feminista coexistir com homens, mesmo que homossexuais. Mas, ao contrário dos integrantes do outro grupo, não desejavam deixar o Somos de uma forma agressiva e não cultivavam desavenças pessoais com nenhum dos homens. Algumas delas até expressaram uma preocupação com a coincidência das defecções do grupo, temendo que isso pudesse levar alguns a confundir os diferentes motivos dos dois grupos.

Porém, os ânimos continuaram exaltados e vários homens, de ambos os lados do "racha", se sentiram traídos pelas mulheres que diziam não querer continuar participando do que consideravam ser uma briga de homens. A onda de sentimento contra a Convergência Socialista que se difundia dentro do Movimento Homossexual também achou terreno fértil no LF, em que algumas mulheres foram acusadas de "pensamento convergente" ou de serem antifeministas. Certas disputas internas, centradas em torno do problema de liderança, também se acirraram, ajudando a criar um clima que alguns meses depois levou à nova divisão.

\section{Ideias e propostas do LF}

Tanto o grupo Somos quanto o LF não tinham uma visão de mundo estruturada. Suas propostas, muitas vezes, tinham um ar improvisado, mas, atrás de suas manifestações, faladas ou escritas, existia um certo corpo de ideias, cuja expressão ocorria de uma forma que parecia mais emotiva do que articulada segundo uma lógica consistente. No LF, como no Somos, eram raros os debates formais. Poucas pessoas tinham experiências das regras de encaminhamento das discussões públicas, que eram geralmente vistas com muita desconfiança, como facilitadoras das "táticas manobristas" atribuídas à política tradicional. Nas discussões, a linguagem usada era outra e o tom era mais o de uma conversa informal entre amigos, na qual não se esperava que os participantes fizessem propostas completas, totalmente pensadas e bem formuladas. Às vezes uma colocação podia tomar a forma de uma simples explosão emocional, uma interjeição jocosa, ou um simples olhar. Esse estilo talvez deva 
sua origem ao fato de mulheres e homossexuais serem então muito marginalizados nos grupos políticos, estudantis, sindicalistas, etc., em que tinham a palavra habitualmente negada e desvalorizada. Portanto, faltava-lhes experiência de falar em público e, em muitos casos, vinham a fazê-lo pela primeira vez dentro de um grupo homossexual. Mas, se não tinham o hábito, também escapavam de muitos vícios de debates políticos e, pelos menos em discussões intragrupais, seus pronunciamentos tinham frequentemente um tom de maior espontaneidade e sinceridade.

Mas, além dessas dificuldades de formalização de princípios do grupo, devidas à inexperiência política e à juventude de seus membros - na época do "racha" a grande maioria das integrantes do LF tinham entre 20 e 25 anos -, o grupo também se tornava mais heterogêneo. Originalmente, o grupo era predominantemente formado por mulheres de classe média, de uma forma ou outra identificadas com a cultura universitária, mas, aos poucos, começaram a surgir integrantes vindas do gueto e de classes mais baixas. Neste momento, além de ser policlassista, o grupo era também multirracial e suas integrantes eram provenientes de várias regiões do país.

Uma das principais funções que esse grupo preenchia para as suas integrantes era a de ser uma alternativa para o gueto. O mundo lésbico de São Paulo era mais restrito que o dos homossexuais masculinos e as opções de comportamento e identidade oferecidas eram muito mais limitadas. As lésbicas tendiam a "se assumir" menos que os homossexuais masculinos e a maioria pareciam viver na "clandestinidade", condição que, na visão corrente no LF, era extremamente prejudicial à autoestima e ao desenvolvimento pessoal. Ao mesmo tempo, o gueto lésbico, centrado principalmente em volta do restaurante "Ferro's Bar", no viaduto Martinho Prado, mas incluindo também outros bares e discotecas no centro da cidade, era também considerado bastante opressivo.

Talvez a contribuição mais importante do LF para a criação de uma nova identidade lésbica na época e o maior foco de sua crítica ao gueto estivessem no campo dos papéis sexuais. O grupo se posicionava firmemente contra o costume do gueto de rotular as lésbicas de maneira rigorosa e definitiva como "lady" ou "fanchona" - existiam 
vários outros termos de uso comum com o mesmo sentido. A primeira seria a parceira "mulher" ou "passiva" e a segunda seria o "macho" ou "ativo". Lésbicas que aceitavam a estereotipação de "fanchonas" muitas vezes transformavam-se em caricaturas de homens, adotando um modo de vestir, andar e falar masculinizado. Os valores geralmente imperantes entre elas eram de um machismo exacerbado, sendo frequentes as brigas violentas entre fanchonas, por exemplo, porque uma teria tentado "roubar" a mulher da outra.

Dentro desse ambiente, o aparecimento de um grupo de lésbicas que assumia posturas feministas, criticando o machismo e recusando rótulos de "lady" ou "fanchona", causava muita estranheza. Elas também destoavam das mulheres do gueto quanto à sua atitude em relação à questão da monogamia. Embora muitas mulheres ingressassem no LF com "casos fechados" - relacionamentos sexuais monogâmicos, depois de certa convivência com o grupo, acabavam "abrindo" a relação, em favor de um relacionamento menos voltado para uma só pessoa.

Embora não pareça ter havido pressão consciente por parte do grupo para essa abertura dos casos, a sua prática tendia a promover isso. As reuniões de "reconhecimento" e muitas das discussões informais entre membros do grupo levavam a um grande desnudamento da vida íntima e afetiva das integrantes. Assuntos que normalmente só seriam abordados em conversas entre amantes ou amigas muito íntimas passavam a ser tratados com todas as integrantes do grupo. Isso potencializava o grau de intimidade e afetividade dentro do LF, que passava a ter muito da função de apoio, antes exclusividade do "caso". Por outro lado, a influência do contato com os homossexuais masculinos - tradicionalmente mais promíscuos que as lésbicas - também levou a um questionamento consciente da monogamia e até à proposta de sexo grupal. Isso realmente era demais para as mulheres do gueto, que já se escandalizavam com o hábito, comum no Movimento Homossexual, dos militantes se beijarem na boca ao se encontrarem ou ao se despedirem. Por isso, no gueto, as integrantes do LF eram frequentemente consideradas como "galinhas".

Talvez o fato mais representativo do desejo das militantes do LF de produzirem uma nova identidade sexual fosse a ênfase dada por elas à palavra "lésbica". Embora esse termo fosse de uso corriqueiro 
nas ciências sociais, no jornalismo e entre pessoas heterossexuais, no gueto lésbico, ele era visto como altamente ofensivo, sendo preferidos os termos "fanchona”, "sapatão", "boy", "entendida”, etc. Quando o Somos discutiu o "esvaziamento" da palavra "bicha", as mulheres propuseram em contrapartida que o mesmo fosse feito com "lésbica", que era como elas se autodenominavam. Tal proposta sempre provocava reações adversas por parte das frequentadoras do gueto, o que levou o LF a distribuir o seguinte panfleto:

Homossexual. Mas pode me chamar de lésbica.

E por que não? Procure em qualquer dicionário e você verá que a palavra lésbica tem, por definição 'mulher homossexual'. Alguma ofensa nisso? Nenhuma, mas essa sempre foi usada com o intuito de ferir por uma sociedade heterossexual que não admite que ninguém saia dos padrões que ela considera 'normais e aceitáveis'.

Além de não ser nada ofensivo em si, a palavra lésbica tem uma origem muito bonita, que remonta aos tempos da antiga Grécia, à ilha de Lesbos, onde a poetisa Safo viveu e cantou a beleza do amor entre as mulheres.

Se você transportar essa palavra para o seu dia-a-dia, ela vai perder gradualmente essa capacidade de ferir, você está desarmando o inimigo. Esse é justamente um dos trabalhos do 'LF', esvaziar a conotação pejorativa, ofensiva, que a palavra lésbica carrega, mostrando que ela não precisa estar necessariamente associada a uma agressão.

Grupo de Ação Lésbica-Feminista - Caixa Postal 293-SP

Esse texto nos remete à dificuldade generalizada que as integrantes do LF diziam ter em falar a linguagem do gueto e em se aproximar de suas frequentadoras. Entre estas e o LF, existia inicialmente uma diferença de classe, já que as mulheres do gueto eram, em geral, de um nível socioeconômico mais baixo. Apesar das diferenças, essa área de atuação era considerada da maior importância e tentativas constantes eram feitas para alcança-la. Alguns exemplos podem ser citados. Quando as então integrantes do Somos escreveram um artigo sobre lésbicas para o Lampião, elas dedicaram uma grande parte do seu tempo para a venda do jornal no Ferro's bar e adjacências. Quando houve o forte esvaziamento do grupo, no final de 1979, as quatro 
que restaram fizeram um questionário para ser distribuído no gueto. Algum tempo depois, elas passaram várias semanas organizando sessões de bingo na discoteca predominantemente lésbica "Mistura Fina", aos domingos à tarde. Esse bingo era visto como tendo duas finalidades: a de ajudar a arrecadar dinheiro para pagar o aluguel da sede do grupo e a de travar contato e tentar influenciar, de alguma forma, as frequentadoras do gueto. Os prêmios oferecidos eram livros e discos feministas e a programação musical incluía muita música brasileira. Também houve uma participação do LF em algumas atividades noturnas do "Mistura Fina" e várias festas do grupo foram realizadas naquele local. Durante algumas dessas festas, que contavam também com a participação dos frequentadores habituais da casa, foi mostrado um audiovisual, montado pelo grupo, contando a sua história e as suas intenções. Mas, mesmo com essa programação, que as lésbicas do gueto parecem ter achado um tanto amadora, o LF não conseguiu mobilizar mais maciçamente o gueto e acabou resolvendo abandonar o trabalho na discoteca.

Outra dificuldade que apareceu era relacionada à natureza diversa dos objetivos da dona do "Mistura Fina" e das militantes do LF. A primeira visava primordialmente o lucro e, para isso, tinha que manter boas relações com as autoridades policiais e políticas. As militantes, porém, se colocavam em oposição a vários aspectos da ordem estabelecida apoiado por ela. Um dos pontos de atrito parece ter sido o uso da palavra "lésbica", que ela, como outras frequentadoras do gueto, achava "feia". Consequentemente os convites para as festas no "Mistura Fina" falavam só do grupo "L Feminista".

De certa forma, o grupo acabou se tornando um "gueto dentro do gueto” e suas integrantes, além de compartilharem uma série de ideias e atitudes sobre o lesbianismo, também passaram a constituir um grupo social mais ou menos fechado. Elas se frequentavam assiduamente, saindo sempre juntas e desenvolvendo relações amorosas dentro do grupo. O apartamento de uma delas, por ser localizado perto do centro e por ser bastante grande, acabou virando uma espécie de "pensão LF", até que sua dona, depois de muitas importunações por parte dos vizinhos, resolveu se mudar e restringir o uso de sua nova residência. 
Era em volta da "luta contra o machismo" que parecia haver maior possibilidade de unanimidade dentro do grupo. Foi esta a primeira bandeira que as mulheres levantaram em suas disputas com os homens do Somos e era nessa questão que elas mais se aproximavam das feministas heterossexuais. Um dos problemas dessa discussão parecia ser a falta de precisão do termo "machista" que, embora geralmente usado em referência à opressão direta da mulher por parte do homem, pode ser extrapolado para cobrir uma grande variedade de relacionamentos envolvendo dominação/submissão.

Durante a época da crise, em meados de 1979, falou-se muito em "machismo" dentro do Somos, mas, dada a falta de precisão do termo e a falta de uma postura de autocrítica real e profunda da parte dos integrantes do grupo, o termo ficou bastante desgastado. Mas vale apena examinar algumas das maneiras em que o problema foi abordado.

Como já vimos, a primeira denúncia de "machismo" no Somos feita pelas mulheres foi a respeito da linguagem comumente usada no grupo. Além das mulheres do grupo serem englobadas nas categorias "bichas" - elas exigiram que se dissesse "bichas e lésbicas" -, havia referência, geralmente cômica, às "rachadas". Este termo é de uso comum no gueto homossexual masculino e sua carga de misoginia é transparente, dando a entender que as mulheres seriam defeituosas de alguma forma.

O uso daquela expressão era intolerável para as mulheres e foi objeto de uma campanha explícita. Mas, devido à rotatividade constante dos participantes do Somos, essa campanha tinha que ser constante, o que as mulheres consideravam altamente desgastante. Tentavam, também em vão, evitar que os homens referissem a si no feminino e as mulheres costumavam fazer as concordâncias gramaticais com a palavra "bicha" no masculino - por exemplo, "o bicha burro" em vez de "a bicha burra". Também procuravam combater o uso pejorativo da expressão "puta". Essas tentativas não prosperaram entre os homens, mas as integrantes do LF continuaram a chamar a atenção, uma das outras, cada vez que usavam termos tidos como "machistas". Quanto ao uso de palavrões em geral, haviam duas posições: uma era totalmente contra qualquer expressão desse tipo, dizendo que seu emprego era um hábito masculino falocêntrico, não havendo razão 
para mulheres fazê-lo. Outra corrente não era contra o uso de palavras fortes, contanto que devidamente adaptadas ao uso por mulheres, - por exemplo, em vez de dizer "estou de saco cheio" falaria-se "meus ovários estão saturados". Porém o hábito de usar palavrões, firmemente enraizado em toda a juventude de São Paulo, logo se mostrou impossível de eliminar. Em geral, essas tentativas de mudança linguística eram vistas com antipatia e como sinal de falta de senso de humor, acabando por serem abandonadas.

Outras supostas manifestações de "machismo" eram também detectadas. Às vezes essa expressão tornava-se quase sinônimo de "autoritarismo". Assim, o hábito de levantar a voz durante discussões, usar formas dissimuladas para conseguir certos objetivos, "manobrismo", monopolizar posições de poder, "cupulismo", não concordar com as reivindicações de autonomia das mulheres, tentar controlar a vida de um parceiro sexual, demonstrar ciúmes, e usar a força física para resolver discussões, eram todos rotulados de "machismo".

A atuação de elementos, ligados à Convergência Socialista, em relação ao LF foi vista por algumas das suas militantes como "machista”, no sentido de não colocar suas intenções claramente, de conquistar a afetividade das pessoas para fins estritamente políticos e esconder, atrás de uma aparente abertura para o diálogo, o propósito inabalável de levar adiante resoluções já discutidas e decididas dentro daquela organização.

A discussão a respeito da atuação da Convergência Socialista foi bastante intensa dentro do LF, a partir da época do I EGHO e do racha do Somos. Embora se posicionando de forma menos radical contra a CS e outros grupos socialistas do que os homens que saíram para formar o novo grupo homossexual, Outra Coisa, muitas das lésbicas - nem todas, pois uma ou duas militavam na Convergência Socialista - ficaram ressentidas com aquele grupo político. Em geral, corria um temor, dentro do LF, de que pessoas de ideologia socialista tentassem diluir as lutas especificamente lésbicas e feministas na "luta geral", ou seja, que a luta antimachista fosse reduzida à luta de classes. Isso não quer dizer que as integrantes do LF se vissem como antissocialistas e a favor do regime então vigente. A sua participação, por exemplo, no ato público de 19 de Maio em Vila Euclides, mostrou isso. Simplesmente, 
achavam que também existia uma luta feminista que a esquerda no momento não comportava. Algumas - mas não todas - achavam que, do mesmo modo como a esquerda procurava se infiltrar no movimento feminista, também as feministas deveriam procurar se infiltrar na esquerda. Uma delas dizia que não era contra algumas mulheres do LF fazerem curso de marxismo na Convergência Socialista, mas que era contra "se dar curso de marxismo no LF".

Como já se constatou, o LF era sujeito a grandes variações no número de suas integrantes. No período imediatamente após a divisão do Somos, o grupo contava com entre dez e vinte e três integrantes. Suas reuniões, frequentadas normalmente por uma média de 15 participantes, aconteciam duas vezes por semana, na sede do grupo localizada em Vila Madalena. Essa, usada em dias alternados pelo LF e pelo grupo feminista Brasil-Mulher, consistia em uma sala, um banheiro e uma cozinha. As reuniões se davam com as participantes sentadas em círculo e muitas vezes terminavam com o grupo todo saindo para jantar, geralmente no "Ferro's Bar". Apesar de mudanças que ocorreram depois, como a saída de muitas fundadoras do grupo, a entrada de novas integrantes e a transferência da sede para uma sala na Rua Aurora, no centro da cidade, este padrão tendia a se manter.

O financiamento do aluguel da sede sempre foi problemático e eram muitos os expedientes usados para arrecadar o dinheiro necessário. Organizavam-se festas, bingos e churrascos, mas o lucro proporcionado frequentemente não era suficiente e, em última instância, algumas militantes, em melhores condições financeiras, acabavam ajudando a pagar o aluguel com seu próprio dinheiro. Porém, como se pode imaginar, isto era causa de muitos problemas, pois, em um grupo em que todas deveriam ser iguais, a contribuição desproporcional de algumas inevitavelmente introduzia um elemento de desigualdade de poder. Além do aluguel, outra despesa grande era a edição esporádica do jornal Chanacomchana, no qual eram publicadas notícias e entrevistas relacionadas com o lesbianismo. Também neste caso, quando o dinheiro proveniente da vendagem não era suficiente, algumas integrantes cobriam a diferença do seu próprio bolso.

Depois de sua saída do Somos, as integrantes do LF foram muito criticadas pelos homens dos dois outros grupos resultantes da divisão. 
Alguns, que permaneceram no Somos e que priorizavam a unidade do movimento homossexual, criticavam-nas por terem saído do grupo e de lhes ter tirado a possibilidade de aprender mais sobre o seu machismo individual e grupal. Ao mesmo tempo, integrantes do grupo dissidente Outra Coisa as recriminavam por não terem se juntado a eles na acusação de que o Somos estaria dominado por elementos ligados à Convergência Socialista e outros grupos trotskistas ou socialistas. Tanto os membros do Somos quanto do Outra Coisa também as acusavam de darem mais prioridade ao feminismo do que à militância estritamente homossexual. Isso elas negavam e, como tentativa de esclarecimento de sua posição, mandaram um comunicado ao jornal Lampião em que enfatizavam a sua posição enquanto grupo homossexual e até principiavam a reconhecer a heterogeneidade no seio do seu grupo.

[...] não cabíamos no Somos enquanto mulheres, já que, como explicado anteriormente em nossa carta, temos que nos organizar separadamente para atender às nossas especificidades, o que não era absolutamente o caso das bichas. O que fizemos foi apenas tomar pública uma situação que já havia de fato: a nossa independência.

Isso não significa, porém, que estamos fora do movimento ou que agora sejamos apenas um grupo feminista. Ao efetuarmos um trabalho junto às feministas estamos buscando atender a outra faceta prioritária de nosso movimento, uma vez que somos um grupo de mulheres. Buscamos, também, ampliar o universo de atuação dos grupos homossexuais, através deste novo espaço conquistado.

Em suma, trouxemos para o movimento homossexual o cunho revolucionário do movimento feminista - a busca de uma nova práxis transformadora da realidade social. Queremos frisar que continuamos a ser um grupo lésbico e que o feminismo apenas nos acrescentou novas frentes de luta.

Completamos um ano de vida duas semanas depois da separação com o Somos/SP e, olhando para trás, nos defrontamos com a necessidade de uma avaliação crítica de nosso histórico. Enquanto estivemos ilhadas num grupo masculino, nossas atenções foram repartidas em função do inimigo comum: o machismo. Com nossa autonomia, concomitante ao crescimento do grupo, as diferenças entre nós se acirraram, já que passamos a nos preocupar com uma série de diferenças que antes não tínhamos nem condições de aprofundar. 
Então, se por um lado a autonomia nos deu maior liberdade de atuação e profundidade, por outro, também, aumentou a responsabilidade de nos reconhecermos e de convivermos com uma série de divergências nunca afloradas, por falta, inclusive, de um espaço específico $[. . .]^{3}$

\section{O GALF e o Movimento Feminista}

Como foi dito anteriormente, os contatos do LF com outros grupos feministas só começaram por ocasião da preparação do II CMP e foi a partir deste contato que elas aprofundaram mais seu conhecimento da teoria feminista. Apesar de uma resistência inicial, por parte das heterossexuais, depois de algum tempo, as desconfianças foram, em boa parte, superadas e as lésbicas aceitas em pé de igualdade com as outras mulheres. Isto não significa que não tenham surgido desavenças ocasionais entre o LF e outros grupos feministas, mas este tipo de discordância intergrupal também é comum entre as entidades feministas predominantemente heterossexuais. Dentro do movimento feminista, a certa altura passou a ser senso comum considerar que, enquanto as heterossexuais tinham muito a ensinar para as lésbicas em relação à teoria política, estas tinham uma grande contribuição a dar, no sentido de ressaltar a importância da sexualidade feminina. Um indício que foi considerado importante da integração do LF dentro do movimento feminista foi o fato das lésbicas virem a dividir a sede, durante vários meses, com o grupo Brasil-Mulher, antes um dos maiores opositores à participação do LF no II CMP.

Porém, mesmo com a aceitação, por parte das feministas em geral, do lesbianismo como manifestação válida da sexualidade feminina, continuava a existir uma série de problemas entre as lésbicas e as militantes heterossexuais. Um dos principais focos de desentendimento era o fato de que muitos dos esforços das feministas eram voltados para a promoção de mudanças nas relações entre homens e mulheres, enquanto as lésbicas simplesmente buscavam evitar tais relações. Para as homossexuais, questões como a legalização do aborto, o compartilhamento das tarefas domésticas com o marido, a questão

3 Lampião, p. 5, ago. 1980. 
do divórcio, etc., não pareciam diretamente relevantes. Além disso, muitas vezes, os grupos feministas procuravam apoio em outras instituições sociais, como a Igreja ou partidos políticos, nos quais a homossexualidade era vista com reprovação. Gerava-se, dessa forma, uma certa má vontade para com a questão lésbica, por causa de suas implicações embaraçosas na política geral.

Dessa forma, as lésbicas militantes frequentemente se encontravam mais ou menos isoladas num ponto de intersecção entre o movimento homossexual e o feminista. A ambiguidade dessa situação era frequentemente manipulada segundo as conveniências políticas e ora elas se declaravam feministas, ora homossexuais. Mas a especificidade lésbica era continuamente lembrada sob a alegação de uma "dupla opressão". ${ }^{4}$ Essa tática voltou a se tornar evidente numa nova divisão sofrida pelo GALF alguns meses após o "racha" do Somos, conforme veremos a seguir. A aproximação com os outros grupos feministas, que já começara a se delinear durante os preparativos do II Congresso da Mulher Paulista, tornou-se mais efetiva ainda com a participação do LF no Comitê de Defesa das Prostitutas. Esta era uma "frente intergrupal", formada inicialmente para dar apoio a um movimento de prostitutas, com o objetivo de denunciar uma série de violências e arbitrariedades contra elas, perpetradas tanto pelos clientes quanto pelos policiais. A adesão desse comitê à campanha orquestrada pelos grupos homossexuais contra o Delegado Dr.Wilson Richetti e sua “operação limpeza" serviu para selar uma aliança entre as feministas heterossexuais e as lésbicas.

Pouco depois, nos dias 21 e 22 de junho de 1980, realizou-se um encontro feminista num convento nos arredores de Valinhos, onde foram discutidas as tentativas de cooptação do movimento de mulheres por parte dos grupos de militância político-partidário e onde se procurou delinear as especificidades do feminismo. ${ }^{5}$ Nessa ocasião, integrantes do GALF -como o LF passara a se chamar após romper com o Somos - tiveram uma atuação importante, especialmente nas

\footnotetext{
4 Ressaltando essa identidade especial, enfatiza-se muito a denominação "lésbica". Embora o termo "homossexual feminina" seja considerado aceitável, devido à sua conotação de neutralidade científica, evita-se o uso do termo "gay" para mulheres.

5 Sobre o encontro de Valinhos, ver.(PONTES, 1986, p. 62-68).
} 
discussões sobre sexualidade feminina, sobre a qual há muito vinham pensando. Sua presença, enquanto lésbicas assumidas, serviu também para enfatizar o clima de sedução e erotismo entre as participantes e apresentar a homossexualidade como mais uma possibilidade de liberação e gratificação acessível a qualquer mulher.

Um dos principais resultados desse encontro foi a criação de uma Comissão de Luta Contra a Violência Sofrida Pelas Mulheres com representantes de todos os grupos feministas, incluindo o GALF. Logo, essa comissão veio a se constituir como uma entidade autônoma, adotando o nome de SOS Mulher - SP. Durante o seu período de consolidação, essa nova entidade passou a ser o palco de discussões radicais sobre a situação da mulher e as formas de luta que lhe eram possíveis e desejáveis.

Inicialmente, as integrantes do GALF assumiram uma postura marginal diante das outras feministas. Suas intervenções eram caracterizadas por uma ambiguidade decorrente de se posicionarem ora a favor da dissolução da entidade lésbica no interior do trabalho feministas realizado pelo SOS, ora em defesa da especificidade da militância lésbica. Essa questão, colocada de forma nebulosa no princípio, acabou por adquirir contornos mais definidos, quando duas das mais influentes militantes do GALF, Z. e L., romperam o caso que tinham desde os primórdios do Somos. L. passou a namorar M., outra integrante do grupo, formando-se, então, um triângulo amoroso, cujas tensões não só contribuíram para uma ruptura do GALF, como serviram para chamar atenção de todas as participantes do SOS-Mulher para a possibilidade delas também aderirem ao lesbianismo.

Ao relatar essa nova dissenção, Pontes destaca a maneira como o posicionamento teórico e as relações pessoais intragrupais se influenciam mutuamente e como isso pode se dar de forma explícita, sob o lema "O pessoal é político" partilhado tanto pelos militantes homossexuais quanto pelas feministas. A antropóloga mostra como surgiram novas dissidências e alianças em torno de Z. e de M., no qual desavenças sentimentais apareciam revestidas de concepções políticas distintas, relativas a diferentes formas de conceber orientações sexuais.

Z. e suas aliadas retiraram-se do GALF e passaram a negar a identidade lésbica, enquanto identidade política. Ao privilegiar a identidade feminista, argumentavam ser sua prática lésbica uma particularidade 
a mais de suas vidas e não a marca identificadora de sua identidade. Esta derivaria, sobre tudo, de sua condição estrutural de subalternidade, resultado delas serem mulheres numa sociedade patriarcalista. Para elas, o SOS não tolhia suas relações sexuais ou afetivas e lhes parecia fazer mais sentido permanecer naquele grupo, em que poderiam militar ao lado de um espectro mais amplo de mulheres.

M. e suas simpatizantes, por outro lado, optaram por continuar a usar o nome GALF e a se desvincularem do SOS. Para elas, o lesbianismo deveria ser encarado como uma questão de identidade social e política; não como simples prática sexual. Achavam que o lesbianismo precisava ser "assumido", por todas que a praticavam, não se podendo simplesmente subsumir a luta homossexual na feminista (PONTES, 1986, p. 118).

Levando-se em conta as divisões internas do LF quando ainda integrava o Somos e as acusações de "cupulismo", então correntes contra algumas das protagonistas dessa nova cisão, as similaridades entre esse episódio e o "racha" daquele grupo ajudam mais uma vez a refutar a visão simplista que procura entender aquele incidente somente a partir de diferenças nas concepções sobre o grau de autonomia necessário ao movimento homossexual.

\section{Adé-Dudu - O combate ao machismo entre os negros e ao racismo entre os homossexuais ${ }^{6}$}

Homossexuais sempre tiveram uma atuação importante dentro das entidades negras de cunho religioso, artístico e cultural. Fry (1982), por exemplo, discute a grande proporção de homossexuais entre fiéis e sacerdotes dos cultos afro-brasileiros, especialmente no norte e no nordeste do país. Nesse meio, o homossexual, chamado de adé, tem um lugar definido no sistema classificatório vigente, ao qual correspondem direitos e deveres. São inúmeros os casos

\footnotetext{
6 As informações contidas aqui sobre a atuação do Grupo Adé Dudu são, em grande parte baseadas no trabalho de Wilson Santos: "A participação dos homossexuais no movimento negro brasileiro", distribuido em xerox pelo grupo Adé-Dudu no ano de 1984. Lembra-se que as ideias e atitudes, atribuidas aqui a militantes negros, se referem a um periodo no início da década de 1980 e não correspondem necessariamente ao tempo da atual edição deste livro.
} 
de pai de santo que vivem abertamente a sua homossexualidade e é nos terreiros que esta manifestação sexual goza do seu maior prestígio dentro da comunidade negra. Em outras entidades negras mais voltadas ao lazer e à cultura, tais como as escolas de samba do Rio de Janeiro ou os afoxés e blocos em Salvador, por exemplo, também se encontram muitos homossexuais "assumidos", geralmente envolvidos, juntamente com as mulheres, nas atividades de apoio, tais como a confecção de fantasias, adereços, alegorias, etc. Porém, as tarefas de direção e representação das escolas ficam a cargo dos presidentes e demais diretores, identificados como "machos".

Homossexuais podem também ser encontrados nas organizações negras de cunho mais político-reivindicatório, embora lá seja menos comum uma postura "assumida", e o preconceito anti-homossexual seja frequentemente expressado usando-se termos como "vergonha da raça”. É também corrente entre militantes negros a ideia de que a homossexualidade seria um "vício de branco", originalmente desconhecido na África. De acordo com essa visão, adotar um comportamento homossexual seria equivalente a ser "negro de alma branca". Curiosamente, essa postura preconceituosa parece mais arraigada entre os militantes políticos do que entre a "massa", segundo nos relata um documento produzido pelo grupo baiano de negros homossexuais Adé-Dudu:

Quando se afirma que a comunidade negra não está prepa-
rada para discussões desse tipo, tem-se observado que este
despreparo está principalmente nos militantes, na vanguar-
da, pois o relacionamento que o nosso grupo tem tido com os
militantes de vanguarda sempre foi mais difícil do que com os
negros menos politizados ou menos intelectualizados. (SAN-
TOS, 1984, p. 28)

Diz-se que o silêncio do movimento negro a respeito da questão homossexual afasta muitos militantes em potencial e que os negros homossexuais que se engajam acabam trabalhando muito mais que os companheiros heterossexuais, talvez como uma maneira de angariar simpatia e aceitação. As mulheres negras, outro grupo similarmente marginalizado dentro das organizações, fazem acusações parecidas, o que leva esses dois segmentos a frequentemente unir forças em um combate ao machismo percebido. 
Esse traço é atribuído, por eles, às condições de exploração que os negros sempre sofreram nas Américas. Trazidos para cá como escravos e destinados a um trabalho exclusivamente braçal, os homens negros sempre foram valorizados a partir de sua força física e de sua potência reprodutora, capaz de gerar novos trabalhadores. O homem negro passou a ser o estereótipo da "macheza", em seu aspecto mais animalesco, e, como este era atributo masculino valorizado pela sociedade como um todo, ocorreu uma internalização desse conceito, por parte dos próprios negros, que em muitos casos chegaram a considerá-lo uma das poucas qualidades positivas de sua raça.

Porém, já a partir de 1978, surgiam manifestações de repúdio a essa atitude. Em maio daquele ano, a antropóloga negra Leila Gonzales realizou uma série de conferências em que denunciava a discriminação racial e suas funestas consequências para o negro, tais como: o desemprego, o subemprego, a falta de espaço para ele nos meios de comunicação, sua ausência entre os detentores de poder político e a opressão sofrida pela mulher negra. Aproveitando o ensejo, um membro do público, um rapaz de nome Passarinho, levantou a questão dos negros homossexuais que seriam discriminados e rechaçados, tanto pelos brancos quanto pelos negros. Passada uma surpresa inicial, a plateia aplaudiu, marcando dessa forma a inclusão de mais essa problemática entre os temas a serem incluídas na militância negra.

Em março de 1979, quando tanto o Lampião quanto o Grupo Somos já haviam lançado em nível nacional a discussão sobre política homossexual, o assunto foi abordado do ponto de vista negro, num jornal alternativo de Salvador. Era o jornal O Inimigo do Rei, cujo número 4 estampava em letras garrafais a chamada de capa: "Além de preto, bicha”. Dentro, havia uma matéria escrita pelo jornalista negro Hamilton Vieira, além de vários depoimentos de homossexuais masculinos negros e brancos, assim como de representantes de entidades negras. Todas confirmavam a discriminação sofrida por homossexuais negros. A matéria começava da seguinte maneira:

Ser negro é ser minoria, logo estigmatizado. Nesse contexto como o homossexual de cor se vê? O fato de ele ser negro não influi no aspecto da marginalização ser mais forte? Ele não sofre mais acentuadamente a repressão imposta a todos os 
homossexuais devido ao fator cor? Outro aspecto a ser levantado é o seguinte: vivemos numa sociedade onde os valores culturais predominantes são de origem europeia. Nessa sequência de valores quase exclusivamente brancos, como se situa o indivíduo que possui características culturais distintas das desejáveis por toda uma sociedade? No caso, por exemplo, do homossexual negro, o primeiro dado a ser levantado é este: no nosso país, a homossexualidade é marginalizada e até vista por muitos como uma espécie de crime. O outro dado a ser analisado é que as características culturais do negro, principalmente no campo da estética, não correspondem aos ideais desejáveis pela sociedade. Dentro desta engrenagem, como se situa o negro homossexual? (apud SANTOS, 1984)

A seguir, o autor enfatizava as diferenças entre as profissões dos homossexuais negros e brancos, constatava o elevado número de homossexuais nos terreiros de candomblé e comentava a preferência dos turistas, principalmente os europeus, pelos negros enquanto objetos sexuais.

Quando, em dezembro de 1979, o Movimento Negro Unificado realizou no Rio de Janeiro seu $1^{\circ}$ congresso, as mulheres, apesar da oposição de muitos homens, resolveram fazer uma sessão, à parte, para discutir seus problemas específicos. Dessa reunião participou novamente o militante Passarinho, que expôs as dificuldades dos homossexuais e ressaltou as semelhanças entre os problemas enfrentados por eles e pelas mulheres. Embora nessa hora somente um outro rapaz de São Paulo tenha se apresentado publicamente como homossexual, posteriormente vários procuraram Passarinho, em particular, para manifestar seu apoio. Essa teria sido a primeira discussão da questão, feita em uma reunião de caráter interestadual dentro do MNU.

As repercussões dessas discussões fizeram-se sentir em São Paulo. No dia 26 de julho de 1980, durante uma reunião geral do Grupo Somos, que buscava então se reestruturar após a cisão que acabava de sofrer, quatro negros do grupo apresentaram uma visão das manifestações de racismo dentro do Somos e no meio homossexual em geral. Alguns dos pontos levantados foram os seguintes:

a) O negro dentro do Somos tinha que ser melhor que o branco médio para ser levado a sério. Ele só era considerado se fosse capaz de levantar propostas e manter discussões (capacidade menos exigida dos brancos); 
b) O homossexual negro tinha que se conformar com um estereótipo. Devia ser alegre, simpático e desmunhecado. Se ele aderisse a este estereótipo, passava a ser aparentemente benquisto pelos brancos. Mas, mesmo assim, sua posição era enganosa, pois, após cumprimentá-lo muito efusivamente e de forma "fechativa", o branco logo estabelecia um distanciamento e, na rua, às vezes até fingia não ver o negro. Esta associação do homossexual negro com a "bicha pintosa" é especialmente relevante, quando se lembra que esta última é alvo frequente de discriminação, mesmo da parte de homossexuais;

c) Os negros eram, muitas vezes, considerados feios pelos brancos e muitos se sentiam rejeitados em nível afetivo. Diziam que brancos nunca queriam ter "casos" com eles, por medo do que outros brancos poderiam dizer. Por outro lado, o negro também era visto como dono de uma sexualidade mais desenvolvida que o branco. Isto às vezes levaria o branco a procurá-lo só como objeto sexual;

d) Dentro do Somos, alguns brancos, seguindo a lógica aceita pelo grupo de que as minorias deveriam se organizar separadamente, às vezes sugeriam que os negros homossexuais formassem seu próprio grupo. Porém, os negros achavam que esse tipo de decisão competia a eles tomar ou não e acabaram resolvendo continuar sua participação no Somos. Ao mesmo tempo, reservavam para si o direito de andarem sempre juntos, uma vez que sua condição específica era um importante elo a uni-los;

e) Quanto à definição de quem seria considerado negro, era classificada como tal qualquer pessoa que se dissesse de descendência africana, não importando o tom da sua pele. Esse último ponto foi mencionado quando surgiram dúvidas, por parte dos integrantes brancos do Somos que estavam presentes, quanto à condição de negro de um dos homossexuais que se colocava como tal.

Depois da explicitação destes pontos, houve uma discussão sobre a prioridade a ser atribuída ao tema, mas, no final, a maioria concordou em considerar as denúncias de racismo no Somos tão importantes quanto as de machismo.

Atuando sob o nome de Grupo de Negros Homossexuais (GNH), esses quatro rapazes participaram também do Festival Comunitário Negro Zumbi (Feconezu) realizado em novembro de 1980, em São 
Carlos. Lá, foram aplaudidos quando um deles leu o manifesto do grupo, onde era enfocada a problemática dos negros homossexuais e a necessidade de se rever valores preconceituosos.

O Grupo de Negros Homossexuais teve uma duração curta (um ano aproximadamente), mas sua influência foi decisiva na criação, em Salvador, do Adé-Dudu - Grupo de Negros Homossexuais. Isto já estava em cogitação desde o ano anterior, quando se formou o Grupo Gay da Bahia, taxado por alguns de racista, apesar da grande proporção de negros e mulatos entre seus integrantes. A criação do Adé-Dudu causou certos constrangimentos no MNU da Bahia, mas, apesar disso, foi possível colocar o tema "O homossexual negro" entre as propostas apresentadas por aquele estado para o $2^{\circ}$ Congresso do Movimento Negro Unificado, realizado em abril de 1981, em Belo Horizonte.

O grupo Adé-Dudu foi oficialmente formado em 14 de março de 1981, por oito rapazes, alguns dos quais eram militantes do MNU, enquanto outros eram independentes. Redigiram uma carta de abertura com os seus objetivos: a luta contra o racismo e o machismo, a eliminação do preconceito dirigido ao homossexual negro e o apoio a todas as demais vítimas de opressão. Nesse mesmo documento, explicava-se o nome do grupo que procurava se manter próximo às suas raízes negras. "Adé", como já vimos, seria a forma utilizada no Candomblé para designar homossexuais, enquanto "Dudu" significaria "negro" em iorubá.

Sua primeira atividade foi a elaboração de um questionário destinado a mapear as diferentes formas de discriminação sofridas pelo homossexual negro. Dos 102 homossexuais negros entrevistados, aproximadamente $90 \%$ afirmavam que existia uma discriminação contra eles. A análise da pesquisa de trinta e cinco depoimentos foi publicada em forma de uma apostila lançada na Semana de Consciência Negra (14 a 20 de novembro de 1981).

Pouco depois de se organizar como uma entidade autônoma, o Adé-Dudu entrou em conflito com alguns membros da MNU, durante um debate realizado para questionar as comemorações oficiais de 13 de maio, considerado pelos militantes negros como a data de uma enganosa pseudo-abolição da escravatura. $O$ fato de dois membros do Adé-Dudu se apresentarem como integrando também o MNU provocou 
críticas, por parte de outros militantes desta agremiação. A situação só viria a ser resolvida em julho de 1981 quando, no Encontro de Entidades Negras, foram expostas as origens e as reivindicações do Adé-Dudu para centenas de representantes do Movimento Negro, vindos de todo o país. O apoio recebido nessa ocasião serviu como confirmação, para os militantes negros baianos, da justeza de suas reivindicações.

Em abril de 1981 foi realizado o $2^{\circ}$ Congresso do MNU em Belo Horizonte. Após conseguir a inclusão da questão do negro homossexual na pauta de discussão, os integrantes do Adé-Dudu tiveram a oportunidade de realizar um amplo debate do tema com a plenária, apesar de poucos dos participantes do congresso se identificarem como homossexuais. As seguintes propostas foram aprovadas, embora poucas viessem a ser realmente implementadas na prática:

a) O início imediato de contatos com os grupos homossexuais ou concentrações de homossexuais dos vários estados membros do MNU, para o início de trabalhos;

b) Recomendação: a questão homossexual deveria ser discutida de forma tal a criar condições de expressão dos homens e mulheres diretamente envolvidos na questão;

c) Os núcleos deveriam criar grupos de reflexão para discutir os temas: homossexualidade, machismo e a questão da mulher;

d) O MNU deveria dar seu apoio aos grupos homossexuais e às suas manifestações;

e) Deveriam ser feitos contatos com grupos ou homossexuais do MNU, com a finalidade de traçar uma política a respeito da questão.

A partir daí, o grupo desenvolveu uma atuação ora mais intensa, ora mais esporádica, voltada principalmente à sua relação com o Movimento Negro. Seus integrantes participaram de vários encontros de negros militantes, tanto em nível nacional, quanto regional e, durante certo tempo, tentaram reanimar o próprio movimento homossexual, quando este começou a dar sinais de exaustão. Produziram também trabalhos de pesquisa social e panfletos sobre a problemática do negro homossexual, ajudando a abrir espaços para essa discussão, tanto nas universidades, como entre os militantes de vários grupos "minoritários". 
Além de seus constantes conflitos com os militantes negros heterossexuais, outra dificuldade foi seu insucesso em conseguir uma participação lésbica, conforme explica Wilson Santos, um dos fundadores do grupo:

Em 1981, quando o Grupo Adé-Dudu realizou e publicou a pesquisa "Negros homossexuais", foi registrada a ausência de depoimento das mulheres negras homossexuais como consequência da repressão a que são submetidas. As companheiras militantes que têm preferência homossexual ainda não conseguiram romper com as barreiras da opressão para se posicionar enquanto pessoas normais que estão dando sua parcela de contribuição na luta por melhores dias, a exemplo do que vêm fazendo vários homens negros homossexuais, nos diversos estados onde existe o Movimento Negro Organizado. (SANTOS, 1984, p. 7)

Segundo Santos, no período que se estendeu entre 1978 e 1984, as militantes negras nunca colocaram em discussão a problemática da negra lésbica. Isso seria especialmente significativo, ao se reparar a frequência com que se discutiam questões relacionadas à sexualidade, já que uma das principais críticas que as militantes negras faziam dizia respeito à exploração sexual da negra nas mãos de homens, tanto brancos quanto negros. Tida como extremamente sensual, a mulher negra seria frequentemente tratada como prostituta e preterida na hora do casamento formal. Outras questões comumente abordadas eram: a exploração econômica, de que é vítima, e as dificuldades que encontra para organizar uma vida familiar. As suas reivindicações seriam, portanto, sempre voltadas para um estilo de vida heterossexual. Eram os homens homossexuais que acabavam se encarregando de levantar a questão lésbica entre os militantes negros. Mas, em geral, suas relações com as militantes negras eram boas, não se devendo esquecer de que foram elas que originalmente lhes haviam aberto espaços dentro do movimento, ao insistirem na importância de temas como sexualidade e machismo. Santos, novamente, resume a posição dos homossexuais da seguinte forma:

Evidentemente não podemos exigir muita coisa desses grupos femininos, uma vez que as próprias interessadas, 
aquelas diretamente envolvidas com a questão, ainda não teorizaram suas reivindicações por sofrerem, mais que os rapazes homossexuais, as consequências do racismo e da discriminação sexual. O que se pode exigir é a coerência necessária para que esses grupos registrem a existência de mais essa problemática e que se abram espaços para que seja discutida. (SANTOS, 1984, p. 22)

Apesar de ficarem frustrados com o silêncio feminino sobre o assunto, os militantes do Adé-Dudu admitiam a existência de diferenças entre a condição dos homossexuais masculinos e femininos. Embora todos os negros fossem oprimidos, os homens, enquanto tais, teriam mais liberdade para viverem a sua sexualidade qualquer que fosse a sua orientação.

Outro foco de atrito para o Adé-Dudu, além dos militantes negros heterossexuais, foi, durante certo tempo, o Grupo Gay da Bahia, também ativo em Salvador. Em relação a esse grupo, era comum a alegação de racismo, apesar da composição daquele grupo ser em grande parte negra e alguns de seus militantes também atuarem no Adé-Dudu. Neste caso, assim como em relação aos conflitos com o movimento negro, um observador superficial da situação baiana, como eu, não pode chegar a conclusões taxativas. O máximo que se pode propor é um convite a uma reflexão mais relativizante, baseada, talvez, nos relatos das experiências do movimento homossexual em São Paulo, ressaltando as tendências detectadas no fracionamento dos grupos e no surgimento de desavenças entre eles. Provavelmente, na Bahia, ocorreu algo análogo ao acontecido em São Paulo, onde os militantes não percebiam claramente certos promotores dessa desagregação, relacionados à própria estruturação dos grupos e à insistência em conceber os homossexuais como uma única categoria social. Preferiam interpretações baseadas na dicotomia "autonomia/política-partidária”. Em Salvador, onde a questão racial é um fator dominante em todas as relações sociais, não é de se surpreender que fosse também invocada para explicar as dificuldades surgidas entre diferentes grupos homossexuais. Mas, o trabalho de desvendar o que realmente ocorria neste caso e em outros subsequentes deve ficar para alguém mais familiarizado com a situação baiana. O objetivo do atual relato 
esgota-se na tentativa de traçar um perfil das várias manifestações paralelas a do Somos-SP, que vieram reforçar a noção de que a questão da sexualidade e, mais especialmente da homossexualidade, pudesse ser encarada de forma política. 


\section{A construção da igualdade: movimento, comunidade e identidade}

A década de 1970 presenciou, em várias partes do mundo, o crescimento em importância de um "terceiro caminho" para a atividade política. Desde então, abandonando a dependência nos partidos tradicionais, tanto de direita quanto de esquerda, vêm surgindo novos movimentos sociais, com propósitos imediatistas para a resolução de problemas específicos e que tendem a manifestar um caráter expressivo, desenvolvendo formas de convivência e participação vividas como positivas em si mesmas.

A Europa tem presenciado o desenvolvimento de movimentos pacifistas, de defesa da natureza, de preservação de certas comunidades contra os abusos da especulação imobiliária, etc. Na América Latina, surgem associações de trabalhadores organizados independentemente ou até em oposição aos sindicatos tradicionais e aos partidos políticos, loteamentos clandestinos organizados como movimentos, comunidades de base da Igreja Católica que se expandem em áreas urbanas e rurais, associações indígenas e negras determinadas a se fazer ouvir e a atuar em nível político, associações de mulheres, grupos 
feministas, comitês de direitos humanos, etc. (CRUZ, 1987; SCHERER-WARREN, 1987; TELLES, 1987; VIOLA; MAINWARING, 1987) Nesse contexto se inscrevem também os grupos do movimento homossexual.

Evers (1983), sociólogo alemão, chama a atenção para certos aspectos comuns a todas essas manifestações políticas, dizendo que nelas se encontra sempre a intenção de experimentar novas relações entre as esferas da vida, normalmente divididas entre a "pública" e a "privada". Busca-se humanizar a vida pública, no sentido de fazê-la funcionar segundo normas e valores mais comumente encontrados na vida privada. Por outro lado, busca-se a valorização do "privado" e o reconhecimento de sua importância como assunto "político", a ser discutido e pensado em pé de igualdade com os outros, mais gerais, que normalmente são considerados de maior importância. Como o próprio Evers (1983) diz, tudo isso constitui muito mais um "estado de ânimo" e uma tendência possível, do que uma prática real; entretanto, seus efeitos na prática organizacional são bastante evidentes. Procura-se constituir grupos pequenos, baseados em relações interpessoais, enquanto agentes ou, pelo menos, componentes celulares; tenta-se evitar especificações, tornando as questões em debate acessíveis e claras para todos os membros do grupo. Experimenta-se com novas formas de democracia de base tais como: o mandato imperativo, a representação rotativa e um processo decisório plebiscitário. Repele-se qualquer tipo de estrutura grandiosa, anônima e burocrática, como o Estado, por exemplo. (EVERS, 1983, p. 34) Já vimos que os grupos homossexuais e feministas exibem várias dessas características. Por outro lado, tendências similares podem ser vislumbradas em organizações que não se propõem tão claramente a fazer política, como a comunidade formada pelos integrantes da companhia Dzi Croquettes - a "família Dzi" -, pioneiros no uso da androginia como forma de contestação cultural, ainda em 1973.

Também nas propostas do jornal Lampião, manifestavam-se valores semelhantes, tanto na sua negação das relações mercantis, intrínsecas ao consumismo, quanto no seu rechaço dos "esquemas prontos" para categorizações classistas, sugeridos pela esquerda tradicional. Procurava-se, ao invés disso, valorizar a percepção e a atuação em nível individual. Porém, essa forma de abordagem pode 
ter desdobramentos bastante complexos ou ambíguos. Exemplo disso foi a atitude aparentemente contraditória do jornal que, apesar de repudiar a mercantilização das relações humanas, se dispunha a defender a prostituição, descartando a sacralização da atividade sexual e preferindo investigar como se davam, de fato, essas relações, sem deixar de salientar também seus aspectos prazerosos. Aqui pode-se perceber a maior importância dada aos indivíduos do que às personificações, característica também detectada por Evers (1983) em vários movimentos sociais.

As novas formas de convivência e participação, gestadas no interior de tais movimentos, constituem tentativas de estabelecer uma prática igualitária que normalmente está implícita na noção de "comunidade". Como mostra Cardoso (1983), a construção desse espaço igualitário da comunidade não se dá pela posse de atributos positivos comuns, mas, ao contrário, pela definição de uma mesma carência. Sendo a comunidade definida por uma experiência comum de discriminação ou opressão, só podem ser reconhecidos, como membros plenos, aqueles que compartilham desta condição, vivendo pessoalmente o problema. Nessas condições, a definição de posições políticas é o resultado de discussões que passam pelas emoções e pela subjetividade, concebidos como áreas privilegiadas para a formação de um espírito coletivo. Dessa forma, a comunidade pode ser percebida como uma experiência de igualdade. Diferenças que possam existir entre os participantes, como as de nível econômico, são tratadas como irrelevantes. Adota-se a oposição clássica, entre a comunidade e a sociedade, para confrontar a unidade de interesse dos grupos de base com a heterogeneidade da sociedade, dividida em classes e recortada por privilégios e conflitos. Supõe-se que entre iguais se possa garantir o consenso e a liberdade. (CARDOSO, 1983, p. 32)

Assim, o Somos-SP exigia que todos os seus integrantes exibissem uma mesma identidade de discriminação e, em várias ocasiões, pessoas que não se identificavam primariamente como "homossexuais" foram até forçadas a se retirar de suas reuniões. A igualdade promovida dentro do grupo era erigida como valor fundamental para todos os aspectos da vida de seus integrantes. Sempre se buscou apagar ou neutralizar qualquer diferença maior que surgisse entre eles. 
Embora seu sucesso nisso tenha sido somente parcial, não se pode negar que uma das preocupações centrais do grupo era com o combate à consolidação de qualquer tipo de hierarquia em seu seio. Em várias ocasiões, por exemplo, mesmo confrontados com a ineficácia do sistema, os integrantes do Somos reafirmaram o princípio de rotatividade absoluta dos coordenadores dos subgrupos, objetivando dar uma chance a todos, mesmo aos seus integrantes menos experientes, de assumir posições de comando. Porém, como já foi visto nos relatos sobre o começo do grupo e suas primeiras crises, o método não conseguiu evitar a cristalização de uma liderança informal e nem que alguns dos aspectos supostamente libertários da estrutura, como a exigência de consenso, fossem usados em certas ocasiões para evitar mudanças que diminuíssem o poder dessa "cúpula".

Um dos métodos usados para promover esse sentimento, de comunidade e de igualdade na carência, era a criação dos subgrupos de identificação/reconhecimento, nos quais se discutiam publicamente as vivências de cada participante em relação à homossexualidade, muitas vezes em grande detalhe. Dizia-se que isso levaria a uma melhor compreensão dos seus significados políticos. Esse processo tinha o efeito de socializar as experiências individuais, ajudando a integrar o que, antes, era fragmentado e encerrado nos limites da vida privada. (DURHAM, 1984) Como resultado, estabeleciam-se relações muito intensas e emotivas entre os participantes, criando uma forte identificação entre eles, frequentemente acompanhadas de sentimentos de euforia e até da fraternidade universal do comunitas.

Encontrando dificuldades em desenvolver um senso de identidade próprio, devido à heterogeneidade da categoria homossexual, as discussões no grupo tiveram mais facilidade em construir o seu suposto contraponto. Para isso, tomavam emprestado o conceito feminista de "machista" ou "machão", erigindo-o como seu inimigo comum. Os homossexuais construíram para si uma identidade complementar: a de "bichas". Como esse "machão" era também contraposto às feministas, estas, especialmente as lésbicas, eram consideradas muito próximas dos homossexuais. Surgia aí o hábito de muitos de englobar na categoria de "bichas", tanto os homens quanto as mulheres do Somos. 
Porém, certas diferenças não podiam ser ignoradas durante muito tempo e a igualdade absoluta, supostamente decorrente da própria condição homossexual, foi colocada em questão por alguns que se viam como sujeitos à "dupla discriminação" e que acabaram formando novos grupos específicos, como o GALF e o Adé-Dudu, por exemplo. Essa segmentação era também perpassada por outra, que dizia respeito aos grupos de amizade e convivência. Esses eram ligados por relações de afinidade pessoal, frequentemente fundamentadas na participação conjunta em um mesmo subgrupo de identificação, ou então em outras características compartilhadas tais como: orientação política, nível educacional, prática sexual preferida, etc.

Como já vimos, inicialmente procurou-se dar pouca ou nenhuma atenção às diferenças de gênero dentro do Somos. Isso levou à dispersão inicial das poucas militantes lésbicas entre os vários subgrupos, sob a justificativa de que assim todos poderiam usufruir das contribuições feministas. Não só se igualavam as mulheres entre si - todas teriam contribuições do mesmo valor a dar-, mas, também se pensava que elas estariam em condições idênticas às dos homens, não tendo, portanto, reivindicações especificamente lésbicas, a serem elaboradas em separado. Também se dava pouca importância às diferenças raciais. Mas, se em São Paulo estas nunca foram muito discutidas, em Salvador, onde a conjuntura era outra, elas foram consideradas motivo para a criação de um novo grupo autônomo - o Adé-Dudu. Este tinha como proposta atuar tanto no movimento homossexual quanto no movimento negro, visando o combate ao racismo, manifestado pelo primeiro e ao "machismo", que seria endêmico no outro.

A diferenciação que se manifestava dentro do grupo, baseada em fatores como: grupos de afinidade, nível cultural, grau de experiência política, etc. pode ser vislumbrada no depoimento em que um rapaz bastante jovem, Zezé, conta a respeito de sua primeira participação em uma reunião do subgrupo de atuação.

Na terceira reunião de identificação, Marquinhos (o coordenador do subgrupo e participante da 'atuação') disse que o grupo de atuação tinha bastante trabalho para fazer e que estava convidando quem quisesse participar da reunião para ir lá. Eu achei ótimo, porque, no fundo, eu queria 
muito isso: entrar no ativismo, para ser uma pessoa bem transitável no grupo, porque, quer queira quer não, se você viabiliza instrumentos de trabalho você se torna uma pessoa conhecida e de bastante trânsito no grupo. Até aquele momento, como eu só frequentava o 'reconhecimento' e ia na casa da Teca, eu não era uma pessoa de muito trânsito. Se eu ia na casa do Edson, por exemplo, tinha pessoas que eu não conhecia, e, então, resolvi entrar para o grupo de atuação.

Bem, quando entrei no prédio e no apartamento eu me senti pior que um verme que lambe a terra e falei assim: 'Ai, estou doida': Achei finissimo, com lareira dentro. Aí falei assim: 'ele no mínimo só assiste filme do Herzog, do Polanski'. Naquela época eu já sabia que existiam filmes assim, existe o cinema artístico, cultural, que eu procurava assistir, mas me sentia totalmente despreparado. Então eu falei assim: 'imagina, esse daqui é o tipo de cara que frequenta o Instituto Goethe, que não sai do MIS, só está no MASP'. Aí eu falei assim: 'Estou louca'. Aí eu entrei, muito humildemente, me sentei num cantinho e aí percebi o clima nas pessoas ... Eu me senti um coitado, só num canto, e o pessoal todo, assim, numa reunião.

Eu vi que tinha pauta e falei 'mas que coisa louca, até a reunião tem pauta'. Achei superorganizado, mas, ao mesmo tempo, eu falei assim: 'esse negócio de pauta me dificulta de participar'. Eu sentia que esse negócio de pauta, como é mais ou menos uma coisa programável, é uma instituição burocrática. Como eu não conhecia a burocracia do relacionamento de vocês, eu me sentia podado, porque se não tivesse pauta, se fosse uma transação mais do livre relacionamento das pessoas era diferente, você se colocava. Mas eu via que se anotava, que tinha uma pauta, então eu me sentia um pouco podado para participar da reunião, ainda mais emocionalmente falando. Porque todo mundo se beijava, se curtia. Só comigo não acontecia isso. Então eu me sentia discriminado, me sentia uma pessoa à parte...

Eu considero esse dia muito importante para a minha visão do SOMOS. Até então eu estava até introduzindo um lado religioso no meu relacionamento com as pessoas, porque eu estava vendo uma espécie de salvação emocional dentro do grupo. Na sociedade, eu não tinha respostas para nada, quer dizer, nem pai, nem mãe podiam me amparar emocionalmente. Eu estava sentindo o amparo através das reuniões de reconhecimento, que todos os grupos consigam transar isso nesse nível, porque é realmente a base da sua discussão emocional. Você tem que partir do emocional mesmo e não tem jeito.

Eu considero muito importante essa reunião porque, quando eu estava nela, enfrentando todas essas barreiras, surgiu o Ricardo III, que falou que tinha uma manifestação do Movimento Negro lá no Teatro Oficina e que precisaria que alguém fosse para lá mais ou menos para representar o grupo [...] Todo mundo pegava coisas para fazer e eu, que tinha vindo com aquela maravilhosa proposta de trabalhar para o grupo, estava vendo que não ia trabalhar porra nenhuma. Que estava todo mundo fazendo coisas e 
eu estava só lá, de bituca, vendo. Aí, como ninguém tinha se oferecido, eu falei bem timidamente: 'Eu acho que posso ir, eu tenho tempo'

Aí o Ricardo se virou para mim, como qualquer pessoa que já está há um certo tempo militando e trabalhando no grupo, e falou assim: 'É, você pode ir'. Quer dizer que eu podia ir porque não ia ninguém mais velho no grupo. Aí, o que acontece, [...] como uma pessoa de fora da órbita das pessoas que estavam há tempo trabalhando no grupo ia fazer uma tarefa, foi discutida a representatividade do grupo e foi falado assim: 'Bem, nesse caso você não vai poder representar o grupo'. Eu pensei no fundinho, no fundinho: 'Porque outro vai poder representar o grupo e eu não?'

O problema da representatividade era o seguinte: ia haver manifestação do Movimento Negro e na hora de assinar qualquer documento eu poderia assinar como uma pessoa, um homossexual pertencente ao grupo Somos, mas não que o grupo Somos estivesse assinando qualquer documento que fosse tirado, lá no Teatro Oficina. Então eu, no fundo, me sentia fora do que eu queria, porque eu queria justamente começar a assumir as coisas do grupo. Isso me magoou mais profundamente quando eu via que, até aquele instante o grupo estava batalhando pelo jornal Lampião, estava batalhando assinaturas. Com isso, eu tinha achado incrivel o potencial de ativismo que o grupo tinha, porque, de repente, eram milhares $e$ milhares de coisas assinadas. Depois eu tinha achado incrível também ver fulano dar tal informe, sicrano outro informe. Eu sentia como se estivesse numa estrutura totalmente voltada para o ativismo. Eu sentia que era uma estrutura em que as pessoas estavam lá para trabalhar mesmo e a pauta reforçava isso.

Já nessa época eu sentia que havia diferenças profundas entre as pessoas. Por exemplo, eu frequentava a casa da Teca e não ocorriam coisas assim e eu me lembro que veio uma pessoa que frequentava as reuniões na casa da Teca e não se enturmou com a reunião. Eu achei isso estranho. Nessa época, eu não conseguia entender muito bem porque havia pessoas que se uniam mais com umas e não com outras. Bem, na hora, eu estava sentindo esse problema mais comigo e aí eu recebia esse balde de água fria. Eu falei assim: 'Vou sair desse grupo porque ele não está dando o que eu quero', porque tem um monte de coisas para fazer e eu não consegui pegar nada, me colocaram de escanteio. É um grupo elitista. Eu estava vendo que os papinhos, que as pessoas tinham, eram que tinham ido assistir tal filme, tal peça ou que artista tal fez tal coisa. Mas não era 'artista tal' no sentido que um homossexual do gueto dá, tipo de novela, de Capricho, Sétimo Céu, não. Era no sentido de como se fosse amigo do artista, que jantasse com ele e, por isso, estava por dentro da vida dele. Então, eu tinha achado um papo elitista mesmo. Me senti totalmente bloqueado e, no final da reunião, já profundamente magoado, eu só tinha contato com uma pessoa.

Aqui, além das diferenças de classe e de nível cultural, percebemos claramente a importância dos grupos de vivência, que costumavam 
se reunir informalmente nas casas de alguns integrantes do Somos. É relevante notar que foram as frequentadoras da casa da Teca que eventualmente saíram para formar o grupo lésbico, não se incluindo, entre elas várias mulheres que pertenciam a outros grupos de afinidade. Vemos também a grande expectativa suscitada pelo grupo em si e que muitos viriam a considerar seu principal amparo emocional, diante da discriminação sofrida perante a sociedade maior. Nesta relação, os integrantes investiam uma grande carga de afetividade e fantasia, tornando o tipo de exclusão, descrito por Zezé, extremamente doloroso.

Nesse relato, vemos as diferenças entre atuação de participantes do grupo com experiência política prévia e os mais inexperientes. Também ficam explicitadas as dificuldades apresentadas pelas normas de procedimento adotadas no Somos, que ora intimidavam os novatos pela sua rigidez burocrática, ora os surpreendia pelas nuances envolvidas nos seus métodos "antiautoritários". Além dessas, havia muitas outras diferenças entre os que participavam das atividades do Somos, sendo especialmente importante a diversidade nas formas de encarar a homossexualidade. Para alguns, seria necessário adotar-se uma postura séria e digna na militância, para outros, o mais indicado seria a "fechação".

Como já foi sugerido, os integrantes do Somos tinham o costume de se autodesignarem como "bichas", sob o pretexto de "esvaziarem" esta palavra de suas conotações pejorativas. Essa forma de tratamento entre iguais, empregando um termo que seria normalmente considerado ofensivo se usado por uma pessoa de identidade heterossexual para designar um homossexual, já há muito era uma prática corriqueira em certos círculos homossexuais. Porém, a tentativa de generalizar esta prática para todos, encontrava inicialmente forte resistência, por parte daqueles que, apesar de se definirem como homossexuais, recusavam o rótulo de "bicha". Isso porque, para muitos, esse termo era sinônimo de "bicha louca", um tipo de homossexual que enfatiza maneirismos efeminados, e que é frequentemente desprezado e discriminado por aqueles de apresentação mais máscula. Mais irritadas ainda ficavam as mulheres do grupo quando a sua especificidade feminina ficava submersa pelo hábito dos homens do 
Somos de se referirem ao conjunto de integrantes como "bichas". Depois de muitos protestos contra essa prática bastante difícil de erradicar, as lésbicas acabaram deixando o grupo. Embora as razões para essa separação fossem várias, uma que recebeu muita atenção foi a de que o uso da palavra "bicha", para englobar também as lésbicas, demonstrava a inabilidade do grupo em reconhecer a situação específica da mulher homossexual. Pode-se dizer que tal costume deixava evidente a cegueira generalizada dentro do grupo para todas as diferenciações existentes entre os homossexuais. A consequência dessa continuada ênfase numa suposta vivência igualitária dentro do Somos foi que não se possibilitou o desenvolvimento nas maneiras de lidar explicitamente com as desigualdades, encontradas não só nos diferentes segmentos do mundo homossexual em geral, mas também entre os militantes, que assegurassem um funcionamento do grupo efetivamente democrático.

Outro fator de diferenciação interna do grupo era relacionado aos diferentes graus de exposição pública a que seus integrantes estavam dispostos a submeter a sua orientação sexual. Em contraste com a postura muito mais furtiva do homossexual tradicional, que procurava esconder a sua orientação sexual na maior parte do tempo, o homossexual moderno, habitante das grandes metrópoles, protegido pelo anonimato relativo, pode se dar ao luxo de ser mais aberto. Porém, mesmo ele, sente a necessidade de tomar certas precauções, especialmente em situações em que o anonimato é menos possível: no trabalho, no lugar de estudo, ou, às vezes, na vizinhança de seu local de residência. Carmem Guimarães nos dá exemplos dessa manipulação da identidade sexual, comparando-a com os Estados Unidos, onde muitos homossexuais sentem a necessidade de "se assumirem" enquanto homossexuais em todas as situações, vinte e quatro horas por dia. Embora o Somos nunca tenha explicitamente adotado uma política de "se assumir" a qualquer custo, na prática, ingressar no grupo implicava em deixar muito mais visível a identidade homossexual. A possibilidade de serem chamados a atuar publicamente, comparecendo a manifestações, carregando faixas ou dando entrevistas, intimidava muitos que preferiam ser "mais discretos" e, portanto, não entravam no grupo para não se exporem demais. 
Um grupo como o Somos, no qual tanta importância é dada à noção de que o "privado" também é político e deve ser discutido em público, torna-se duplamente vulnerável à desagregação. Pois, frequentemente, a exigência de que o debate político, no seu plano mais abstrato e generalizante, fosse tratado em pé de igualdade com divergências e simpatias de cunho pessoal e afetivo, surgidas entre os integrantes do grupo, potencializava o poder desagregador dessas discordâncias e desentendimentos. Muitas vezes, as divergências, que surgiam em níveis políticos e pessoais, acabavam por se alimentar mutuamente, levando a situações de grande polarização de posicionamentos dentro do grupo. Quando um dos princípios básicos desse tipo de organização é a recusa frontal a qualquer tipo de hierarquia, não há nenhuma instância formal de poder que possa fazer uma mediação entre as facções em disputa. Isso levava frequentemente a uma ruptura no sentimento de igualdade e de pertencimento a uma mesma comunidade.

Uma vez rompido tal sentimento, um grupo pode se desestruturar e seus integrantes se dispersarem, ou então formarem novos agrupamentos. Esses novos grupos podem, então, estabelecer relações de aliança com antigos inimigos e brigarem com antigos aliados. Assim, a retirada das lésbicas do Somos pode ser entendida não só como uma afirmação de divergências políticas, mas também como um realinhamento de grupos de afinidade. Percebe-se aí a importância de "fatores pessoais" nos processos internos de diferenciação e identificação.

De toda maneira, o resultado disso foi que o Somos se encontrou, em 1980, perpassado por uma série de clivagens, desenhando diferentes grupos de interesse político e afinidades pessoais. A instabilidade do conjunto era aumentada pelo fato de não haver, no Brasil, um objetivo ou um antagonista muito preciso para a militância homossexual. Ao contrário dos EUA, aqui não existia legislação especificamente anti-homossexual a ser combatida, e a própria repressão policial contra os homossexuais tendia a ser esporádica e assistemática.

Ruth Cardoso apontou que, mesmo no caso de movimentos reivindicatórios que têm o objetivo claro de influenciar o Estado, a natureza multifacetada deste serve frequentemente para confundi-los e esvaziá-los. (CARDOSO, 1983, p. 226) Na situação em questão, quando o objetivo seria provocar uma mudança global na cultura e mudar a 
atitude que grande parte da população adota perante a homossexualidade, o problema se complicava mais ainda.

$\mathrm{Na}$ ausência de um grande inimigo externo claramente delineado, contra o qual lutar, o campo de disputa dos grupos homossexuais acabava restringindo-se ao relacionamento inter e intragrupal. Talvez o "inimigo externo" mais perceptível para esses grupos fossem os partidos políticos institucionalizados e as organizações marxista-leninistas. Isso, em virtude de terem práticas e métodos organizacionais diferentes e de atuarem no mesmo campo "oposicionista", competindo, em muitos casos, diretamente com os novos movimentos alternativos, como sugere Evers (1983).

No exemplo que estamos estudando, esse conflito ocorreu de forma aguda, em relação à Convergência Socialista e especialmente com sua Fração Gay, que procurava aplicar o esquema leninista mais tradicional para a mobilização dos homossexuais. Para o Somos, era intolerável a ênfase, dada por ela, à construção do PT e à constante referência à luta de classes implicitamente tomada como uma "luta maior", na qual questões de cunho sexual seriam tratadas como secundárias

1 A posição da Fração Gay da Convergência Socialista é explicitada na seguinte citação retirada de seu Boletim n. 52, maio/jun. 1981:

HOMOS PT SEXUAIS n. 1 de maio do ano passado, cerca de 60 homossexuais - entre homens e mulheres -, participantes ou não de vários grupos homossexuais de São Paulo, formaram uma Comissão de Homossexuais Pró - $1^{\circ}$ de Maio e deitaram e rolaram com faixas contra a discriminação do(a) trabalhador(a) homossexual e contra a intervenção nos sindicatos do ABC, e fomos aplaudidos em nossa entrada triunfal da Vila Euclides.

Neste ano, foram cerca de 20 militantes homossexuais que estão construindo o PT, levando faixas contra a discriminação ao trabalhador(a) homossexual e contra a Lei de Segurança Nacional. Não fomos aplaudidos, mas ninguém deixou de apreciar nossas faixas que estavam colocadas acima das cabeças dos oradores.

Nós, da FHCS, enquanto militantes homossexuais que participaram destas atividades, colocamos como necessárias e gratificantes as manifestações que venham unificar nosso combate contra a exploração e a opressão que exerce a burguesia e sua ideologia, que há tempos deveria estar sobre as múmias de sua estrutura - as quais os cavaleiros do imobilismo empunham como bandeiras. Muitos perguntam: Por que PT? - Bem, hoje, PT representa todas as brigas travadas pelos setores explorados e oprimidos que, a partir de 77 , se organizaram e estão construindo uma alternativa política para todos os trabalhadores. Um ponto é de real importância: o de ser um partido sem patrões, que está sendo alicerçado pelo empenho dos interessados - os próprios trabalhadores, no que se diferencia radicalmente dos outros partidos. 
A saída das lésbicas do Somos significou a simples formalização de uma diferenciação entre homens e mulheres já existente e mais ou menos aceita dentro do grupo. Sintomaticamente, foi legitimada pelos próprios argumentos de "especificidade das lutas", usados pelos militantes homossexuais em geral. Porém, a divergência entre os homens, na qual as diferenças eram mais difíceis de demarcar, foi justificada pelos dissidentes como devida à ingerência da Convergência Socialista, que teria "feito a cabeça" dos que permaneceram no grupo. Tal acusação e o seu corolário, sobre a perda de autonomia que o Somos teria sofrido, provocaram uma violenta polêmica que durou muitos meses e chegou a destruir ou abalar várias antigas amizades. Para diferenciar grupos tão parecidos, precisou-se recorrer à pior acusação possível - a identificação com os grupos da esquerda tradicional.

Apesar dos grupos esquerdistas, assim como suas formas de pensamento e de organização serem percebidos como o principal inimigo do Somos na época, outros grupos também eram alvos de críticas, o grupo do Teatro Oficina, por exemplo, apesar de ser estruturalmente similar ao Somos e de defender a liberdade sexual, foi violentamente atacado pelos militantes homossexuais, por rechaçar rotulações do tipo "heterossexual" e "homossexual". Um conflito parecido é relatado por Heloisa Pontes, que trata da disputa entre o Grupo Ação Lésbico-Feminista e o SOS-Mulher. (PONTES, 1986, p. 117) Este último grupo era acusado pelas integrantes do GALF de "não assumir" o lesbianismo, apesar deste ser prática corrente entre uma parcela considerável de suas militantes. Estas, em contrapartida, alegavam que a adoção de um rótulo homossexual só serviria para legitimar a divisão arbitrária das mulheres entre homo e heterossexuais.

A adesão rígida a uma identidade homossexual por parte de seus militantes servia para demarcar as fronteiras do chamado "Movimento Homossexual", estabelecendo uma diferenciação em relação a outros grupos libertários, também interessados em mudar a maneira tradicional brasileira de encarar a sexualidade. Por outro lado, o comunitarismo e os fortes laços afetivos que uniam os militantes homossexuais também contribuíam para afastá-los do resto da população com práticas homossexuais. Isso ocorria apesar do "homossexual consciente" - como os militantes concebiam a si mesmos - ser pouco mais do 
que uma versão politizada do personagem que Fry (1982) chama de "entendido" e que é hoje um dos mais constantes frequentadores do gueto. Esse, como já vimos, rejeita a tradicional classificação hierárquica dos homossexuais como "ativos" ou "passivos", "bofes" ou "bichas”, favorecendo uma concepção mais igualitária.

Tal posição era ardorosamente defendida por muitos militantes do Somos e alguns até chegaram a considerar que a promoção dessa nova visão deveria ser a principal tarefa do grupo. Fry (1982, p. 93) considera que essa posição teria se originado nas classes médias dos grandes centros urbanos. Guimarães, fazendo sua pesquisa antes do surgimento do movimento homossexual no Brasil, já percebera, entre os membros da rede de sociabilidade que estudou, a negação da diferenciação entre o "ativo" e o "passivo". "Para estes, a questão de ativo e passivo não se coloca - tudo é "transa". Definem a relação como homossexual, assim como ambos parceiros da relação”. (GUIMARÃES, 1977, p. 110)

Privilegiando a classificação das pessoas como hétero ou homossexuais, os membros dessa rede também afirmavam que sua prática social, não-sexual, era "igual a de todo mundo". Procurando rejeitar estigmas, alegavam que determinados indivíduos "normais", de classe média alta, não só aceitavam, mas até tinham experiências homossexuais, assumindo-as publicamente como "transa" sexual legítima. A prática homossexual era vista como opção e não como "anormalidade”. (GUIMARÃES, 1977, p. 129)

Homossexuais que insistiam no velho estereótipo da "bicha" eram, às vezes, criticados pela sua forma de falar, suas "roupas extravagantes", sua "preocupação só com sexo", e pela sua conduta sexual "passiva", embora também pudessem ser admirados por seu enfrentamento frontal dos preconceitos da sociedade. Carmem Guimarães nos relata que, no carnaval de 1977, os membros da rede que estudava não vestiram fantasias e muito menos se dispuseram a se travestir. Embora costumassem frequentar bailes do Teatro São José e da Gafieira "Elite", conhecidos como "bailes de bichas", não estabeleciam contato com homossexuais efeminados, considerando-se somente espectadores. (GUIMARÃES, 1977, p. 127) Embora o estudo trate de uma rede específica, tudo leva a crer que a sua vivência refletisse os 
valores adotados por amplas parcelas de homossexuais masculinos da mesma faixa socioeconômica no Rio, São Paulo e outras grandes cidades brasileiras. Os indivíduos estudados por Guimarães (1977) vieram a formar, mais tarde, um dos núcleos do grupo Somos-RJ, cujos objetivos seriam, em parte, elaborações, em nível político, de suas visões de mundo.

Tanto entre os “entendidos”, estudados por Guimarães (1977), quanto entre grande parte dos primeiros integrantes do Somos-SP, parecia prevalecer a noção de que o homossexual não diferia das outras pessoas que o cercavam, exceto por suas preferências sexuais. Como já vimos, a prática do ocultamento da orientação homossexual era normal em situações de trabalho, de relacionamento com familiares e conhecidos menos íntimos, como diz um de seus interlocutores:

Geralmente as pessoas, ditas leigas, só descobrem que eu sou homossexual a longo prazo. Você não se apresenta dizendo: 'Eu sou louro, eu sou moreno, ou sou isso ou faço aquilo'. Não tem por que. Não há necessidade. É uma atividade excessiva, gratuita porque, finalmente, você sendo homossexual, é absolutamente igual a todo mundo. (GUIMARÃES, 1977, p. 77)

Porém, a necessidade de adotar uma estratégia de passing, que, em certos casos, leva indivíduos não só a ocultarem as suas preferências sexuais, mas até a simularem uma vivência heterossexual ao inventar namorados e noivas, acaba sendo um fardo desagradável. Muitos sentem que essa é uma estratégia desonesta. Mesmo na rede citada, na qual o passing era uma estratégia frequentemente utilizada, geralmente preferia-se deixar que os outros presumissem uma heterossexualidade não explicitada do que mentir diretamente, inventando falsas experiências heterossexuais. Aqueles que o faziam eram passíveis de sanções que poderiam chegar até a exclusão do grupo. (GUIMARÃES, 1977, p, 76)

Ao discutir a situação de indivíduos que procuram esconder certas características estigmatizantes, Goffman (1968) descreve algumas das consequências psíquicas desse processo. Mostra como essa dissimulação dificulta a formação ou a conservação de relacionamentos, cria uma ansiedade constante e requer uma atenção permanente para evitar que situações inesperadas a comprometam. É também extremamente penoso o sentimento de divisão de lealdades quando, por 
exemplo, um "homossexual enrustido" é levado a ser cúmplice na ridicularização de outro. (GOFFMAN, 1968, p. 108) Assim, muitos homossexuais se sentem oprimidos ao serem forçados a "se enrustir" para evitar vexames ou perseguições.

Além do passing, existem, porém, outras estratégias adotadas para ajudar lidar com uma característica estigmatizante. Em muitos casos, uma das mais eficazes é a sua revelação voluntária, percebida frequentemente como mais honesta e mais digna. Embora nem sempre o elemento de escolha esteja presente - em alguns casos a dissimulação é impossível -, esta é a base de muitos movimentos de "minorias". Como já vimos, no caso dos homossexuais, isto leva a uma curiosa ambivalência na atitude para com aqueles que são "muito bandeirosos”. Às vezes criticados por "serem excessivos", "só se preocuparem com sexo", "reproduzirem os papéis sexuais", etc., em outros casos, são elogiados por sua “coragem" e por "se assumirem".

Para grande parte das pessoas que se identificam como homossexuais, a possibilidade de passar por heterossexual é uma realidade e talvez esta seja uma prática constante. Isto traz mais algumas dificuldades para a organização de uma comunidade homossexual. Nessas condições, é normal se esperar que bastante ênfase seja colocada no "se assumir", ou melhor, que a identidade homossexual seja erigida como a principal verdade do indivíduo. Isso viria ao encontro de uma tendência generalizada na nossa cultura, já apontada por Foucault (1979, p. 68), de se erigir a questão do sexo, a partir do século XVIII, como base para a constituição de um saber do sujeito e a fonte da sua verdade.

Por isso mesmo, ao lado da concepção da homossexualidade como “opção", 2 é ainda predominante a noção de que a identidade homossexual estaria ancorada em uma "essência" imutável, de origem congênita ou então adquirida muito cedo na vida. Essa visão, cuja elaboração teórica data do século XIX, torna-se cada vez mais difundida, vindo a constituir uma espécie de "senso-comum" pelo menos entre as camadas mais cultas da sociedade brasileira, incluindo-se os homossexuais de classe média, habitantes das grandes metrópoles.

2 Atualmente o termo mais usado é "orientação", sem relação com a questão da escolha ou da essência. 
Nas matérias do jornal Lampião, transparece claramente uma ambiguidade na sua concepção da natureza da homossexualidade. Ora defendia-se a legitimidade da homossexualidade, clamando-se pelos direitos de cidadania plena para os homossexuais, ora louvava-se os aspectos contestatórios de sua marginalidade. Para enfatizar a virtude dessa contestação, tornava-se importante ressaltar o seu aspecto consciente. Promovia-se, assim, uma repulsa à noção de que os indivíduos seriam, de alguma forma, pré-programados em relação à sua orientação sexual. Isto, aliado à consciência dos problemas já causados pelo determinismo médico, que apresentava a homossexualidade como patologia, engendrava, também, uma recusa a qualquer especulação sobre supostas etiologias daquela "condição". O individualismo dos homossexuais e sua suposta autonomia, perante as grandes pressões sociais, eram considerados seus maiores dons, por tomá-los "indigeríveis" pelo sistema. Podemos lembrar aqui os artigos de João Silvério Trevisan, advogando o aprofundamento da diferença entre os indivíduos e a normalidade instituída, para "virar a mesa" e "inventar a Utopia”, ou seja, fazer a "revolução pelo prazer". Assim, por um lado, a construção de uma identidade homossexual coletiva era dificultada pela exaltação da individualidade irredutível de cada um. Mas, por outro lado, ao enfatizar a ideia do homossexual já dotado de uma preferência sexual pré-definida, ${ }^{3}$ estabelecia-se um campo em que uma identidade coletiva podia ser construída.

Como corolário de sua marginalização social, idealizava-se o homossexual como eminentemente "antiautoritário". O que significaria exatamente que esse "antiautoritaríssimo" nunca foi discutido com muita profundidade. As origens da ideia podem ser remetidas aos ideais libertários difundidos na Europa e na América do Norte durante a década de 1960. Estes só puderam ser amplamente divulgados no Brasil no final da década de 1970, quando a censura se tornou mais branda. Associada a elas, vieram também algumas concepções muito gerais do feminismo. Sua corrente mais radical legou a noção de que a base profunda das desigualdades sociais residiria nas diferenças entre

3 Era nesse sentido que só se admitiam ao Somos-SP, aqueles que se identificassem como homossexuais 
os papéis sociais atribuídos aos homens e às mulheres. Ignorava-se, porém, que expectativas sobre o comportamento considerado adequado aos dois gêneros apresentam muitas variações, até dentro de uma mesma sociedade, dependendo também de outros fatores, tanto sociais como individuais. Achava-se que relacionamentos homossexuais ao envolverem, por definição, indivíduos do mesmo gênero -confundia-se assim sexo fisiológico e papel de gênero - evitariam a desigualdade de poder dos relacionamentos heterossexuais.

Essa crença numa natureza essencialmente democrática da homossexualidade já era manifestada no primeiro documento produzido pelo grupo paulista em 1978, a sua carta de protesto contra a maneira como a imprensa retratava os homossexuais. Lá, dizia-se que a homossexualidade ameaçava o poder que certos grupos detinham na sociedade, por contestar "a ideologia em que um ser (o macho) domina outro (a fêmea) com uma finalidade - a reprodução”. Vemos aí, de forma exemplar, a elaboração política da emergente visão igualitária da homossexualidade, na qual se rechaçava de vez o velho modelo hierárquico do relacionamento, baseado nas diferentes expectativas em torno dos papéis atribuídos aos parceiros "ativos" e "passivos".

O grupo contribuía, assim, para a construção, no seu seio, de uma nova identidade homossexual. Através de seu ativismo e do seu acesso aos meios de comunicação, ajudava a legitimá-la, como "politicamente correta" e a divulgá-la pela sociedade.

Unindo-se às feministas, no seu rechaço às insuficiências do marxismo em dar conta da questão social, os militantes homossexuais, embora ainda conhecessem pouco dos detalhes da teoria feminista, adotaram alguns de seus métodos anti-hierárquicos de organização e certos conceitos como "machismo" e "patriarcalismo". Porém, o traço mais marcante de sua postura filosófica talvez pudesse ser considerado o individualismo exacerbado.

Essa era uma postura perante a vida compartilhada por amplos setores da população homossexual. Tal característica é muitas vezes conhecida pejorativamente como "solidão" e considerada por muitos como resultado da rejeição geral que os homossexuais sofrem por parte da sociedade e que os levaria a adotar uma postura defensiva de "cada um por si”. Por outro lado, essa atitude poderia ser relacionada à crescente 
tendência à individualização nas grandes cidades ocidentais, já discutida por Gilberto Velho e Louis Dumont, entre outros. O homossexual, muitas vezes desenraizado, fugindo da família para se refugiar no anonimato relativo das grandes metrópoles, seria até uma espécie de ponta de lança do processo.

O individualismo exacerbado é uma versão daquilo que McPherson (1979) chama de "individualismo possessivo", cuja característica básica é a definição do sujeito pela posse de seu próprio corpo. Essa posição nos remete novamente às discussões de Foucault sobre sexualidade e verdade. Ela nos ajuda a compreender melhor como a individualidade passa a ser vista entre nós como intrinsecamente associada à sexualidade e o hedonismo apresentado como uma grande manifestação de liberdade. Portanto, dentro do Somos, a rejeição a qualquer hierarquia ou estrutura organizacional mais restritiva era considerada essencial para a preservação da individualidade de seus integrantes. Reflexo disso seria a ênfase dada à necessidade de se aliar política e prazer, assim como a rejeição de qualquer tipo de "tarefismo" que justificasse trabalhos desagradáveis em nome de um bem-comum. Durante a crise que levou à cisão do antigo Somos, uma das acusações mais contundentes que se podia fazer contra o grupo era dizer que suas reuniões estavam se tornando "chatas".

Outro aspecto desse individualismo hedonista dos homossexuais é a valorização da sua permanente disponibilidade sexual. Essa característica, mais encontrada entre os homossexuais masculinos, mas também presente entre as lésbicas, era refletida nas apregoações do Lampião e na atitude casual com que eram encaradas as relações sexuais dentro do Somos. Questionando todos os tipos de "autoritarismo" ou a "reprodução de papéis" rechaçava-se a monogamia e incentivava-se o "caso aberto", ou então os relacionamentos descompromissados, sendo malvistos sentimentos de possessividade ou ciúmes. Esta liberalidade era, de fato, mais acentuada no grupo do que no gueto, onde a "fidelidade" ainda é uma exigência em muitos relacionamentos que se pretendem estáveis. Esses, porém, são relativamente poucos e, tanto os homossexuais "organizados" quanto "não organizados", geralmente consideram a possibilidade da promiscuidade um dos aspectos importantes da "liberdade sexual". Nisso, no 
Brasil, os homens homossexuais não parecem ser muito diferentes dos heterossexuais. Já as lésbicas frequentemente valorizam mais a monogamia, mas, aquelas que participavam do movimento homossexual também começavam a desenvolver um comportamento sexual menos compromissado. Isso frequentemente as levava a serem consideradas como "galinhas" entre as outras lésbicas que não eram "organizadas".

De fato, apesar desse individualismo ser bastante difundido entre toda a população homossexual, a tentativa do Somos de lhe dar uma manifestação política e de conciliá-la com os preceitos de uma militância organizada e de um ideal de comunidade era de difícil compreensão para grande parcela dos frequentadores do gueto. Esses costumavam manifestar muita desconfiança a respeito de qualquer atividade política e uma certa postura de superioridade, às vezes adotada pelos militantes, também contribuía para torná-los muitas vezes antipáticos aos olhos do resto da população homossexual. Embora nunca se declarassem de maneira formal como uma "vanguarda" dos homossexuais, o que iria contra as suas pregações libertárias de rejeição de qualquer princípio de representação política de um indivíduo por outro, essa postura era assumida frequentemente em conversas informais. Reclamava-se muito das "bichas alienadas" que "não davam valor" aos esforços dos militantes. Um certo desprezo pelos homossexuais "não organizados" transparecia também nesta designação e na sua classificação como sendo do gueto ou "vivendo na clandestinidade".

Saudada originalmente como evidência de um progresso nas relações sexuais, a própria identidade homossexual igualitária - também chamada de "gay" ou "entendida" - começa a ser questionada na segunda metade da década de 80. Alega-se, por exemplo, que contribuiria para uma nova normatização ou reterritorialização das sexualidades desviantes, contribuindo para a sua neutralização e cooptação pelo sistema capitalista. Situados entre seus principais defensores, os militantes homossexuais estariam, portanto, desempenhando um papel conservador. Tais críticas são refutadas em vários níveis. Por um lado, a noção de que a homossexualidade - ou a sexualidade em geral - possibilita o surgimento de "pontos de fuga", em que "pulsões libidinais desterritorizados" se libertariam de condicionamentos culturais para se voltar contra a ordem instituída, pressupõe “impulsos 
selvagens" ou um "desejo" pré-simbólico, anterior à cultura, difíceis de aceitar, para quem considera o humano e o cultural como inseparáveis.

Por outro lado, o estudo mais atento do desenvolvimento dessa nova identidade gay mostra que ela não é estática, mas, ao contrário, é dotada de uma historicidade e se modifica juntamente com o seu contexto.

Nos meados da década de 70, quando Guimarães realizava seu estudo junto aos "entendidos" da zona sul do Rio de Janeiro, os rapazes que pesquisava ainda precisavam afirmar a sua masculinidade perante uma sociedade que, ao empurrar os homossexuais para a clandestinidade, mantinha-se quase inteiramente ignorante a seu respeito, contentando-se em equacionar a homossexualidade com o desejo de desempenhar o papel apropriado ao gênero oposto. É significativo lembrar as dificuldades enfrentadas por qualquer tentativa de discussão pública da homossexualidade que fugisse dos preconceituosos círculos médicos ou jurídicos de então. Em 1977, a revista Isto $E$, por exemplo, ainda era vítima de perseguições policiais por ter dedicado uma longa matéria de capa ao gueto homossexual.

Alguns anos depois, quando a homossexualidade se tornou um dos grandes temas veiculados pelos meios de comunicação de massa, o público já estava bastante inteirado sobre os meandros do mundo gay. Os sofisticados "entendidos" de Guimarães sentem- se hoje livres da necessidade de reafirmar constantemente sua masculinidade e, em certas ocasiões, podem se dar ao luxo de participar junto com outros "bofes", "bichas", "militantes homossexuais", "gays", "homens mesmo", "mulheres de verdade", "sapatonas", etc. da carnavalização dos papéis de gênero, tão ao gosto da população brasileira. Miguel, cuja rede de amizades ela pesquisou, após ser um dos militantes fundadores do Somos-RJ, passou a frequentar um grupo de transformistas, a Turma OK e, no carnaval assume a satírica persona "Divina", saindo à rua elegantemente paramentado com vestidos, perucas, sapatos de salto alto, maquilagem, etc.

Mesmo durante seus primeiros tempos, quando o Somos ainda se empenhava em "educar" o público, difundindo uma imagem "normal" dos homossexuais, brincava-se muito com a questão dos papéis de gênero, e a "fechação" era um recurso utilizado constantemente, tanto na promoção da solidariedade grupal, quanto na contestação política. De fato, tal era a ridicularização da tradicional rigidez dos 
papéis de gênero - refletida, por exemplo, no uso do termo "bicha" com concordância gramatical no feminino, como forma de autodesignação pelos homens do grupo - que isso até ensejava que militantes recém-ingressos no Somos criticassem o que consideravam ser uma representação "estereotipada" da homossexualidade. Mas, depois de frequentarem as reuniões do grupo por algumas semanas, participando das discussões que lá ocorriam a respeito da sexualidade, esses mesmos indivíduos acabavam por adotar atitudes de muito maior tolerância para a imensa gama de variações possíveis no desempenho do papel homossexual. Isso, por sua vez, os diferenciava dos outros frequentadores do gueto, onde prevaleciam padrões comportamentais mais tradicionais, tanto de "bichice" quanto de circunspecção e dignidade. Não é justo, portanto, representá-los como meros defensores conformistas de novas normas para a sexualidade.

Esses militantes do Somos acabavam por formar um grupo bastante sui generis, diferente dos frequentadores do gueto e distinto de outros militantes políticos. O próprio modo libertário de se organizarem servia também para diferenciá-los dos outros homossexuais com experiências de militância em grupos de oposição mais tradicionais. Para estes, era estranha a "anarquia" das reuniões, o desrespeito com que se tratava conceitos, quase sagrados à esquerda, como "luta de classes", assim como a total falta de precisão a respeito dos objetivos do grupo e das maneiras que eles poderiam ser realizados. Desse modo, eram estabelecidas, por exemplo, as diferenças entre os membros do Somos e os da Fração Gay da Convergência Socialista.

Por outro lado, grande número dos frequentadores do gueto, acostumados a considerar como "vitórias para a causa" a abertura de novos estabelecimentos comerciais voltados para o público homossexual, não entendiam muito bem as declarações que o Somos fazia contra a integração dos homossexuais à sociedade de consumo. Enquanto os militantes percebiam a questão homossexual como um estopim para uma revolução social mais abrangente, os "não organizados" tendiam a pensar nela mais em termos de direitos civis a serem conquistados dentro da estrutura social existente.

Estudiosos dos novos movimentos sociais urbanos têm apontado a sua tendência a tomarem a continuação de sua própria existência 
como principal razão de ser, apesar de suas intenções declaradas nomearem como seu grande objetivo a eliminação de determinadas carências. Nos grupos feministas e homossexuais, por exemplo, é comum ocorrerem longas reuniões sem metas pré-estabelecidas e que acabam sem a tomada de nenhuma decisão. Em muitos casos, reuniões "políticas" adquirem uma função puramente afetiva e de sociabilidade. Igualmente, é frequente a interrupção de discussões teóricas para se fazer deliberações sobre a vida privada dos participantes.

É também uma característica constante a ênfase na importância dos aspectos privados da vida dos militantes. Estes percebem sua participação nesses movimentos como uma forma de enriquecimento ou realização pessoal, em contraste com a massificação que ocorreria no mundo externo. É comum ouvir esse tipo de atividade grupal ser relatado em termos que lembram os efeitos de conversões religiosas. No depoimento, já transcrito, do militante do Somos, Zezé, fica explicitado o sentimento "religioso" que tinha pelo grupo. Em se tratando de grupos de militância homossexual, declaradamente voltados aos problemas sexuais e afetivos de seus integrantes, essa dimensão adquire uma importância ainda maior. Muitos de seus integrantes declaravam que procuravam um grupo com a intenção principal de encontrarem novos amigos e talvez até um "caso". Portanto, apesar de seu sucesso inicial, era inevitável que o Somos perdesse muitos dos seus atrativos, uma vez que começaram a se espalhar notícias a respeito das suas desavenças internas e da alegada "tomada" do Somos pela Convergência Socialista.

Tem-se também apontado que esse tipo de movimento, partindo da definição de carências, frequentemente cria a exigência de novos direitos, até então pouco cogitados. No caso em tela, promovia-se a ideia de que todos deveriam ter o direito "ao prazer" e à gratificação sexual, independentemente do objeto de seu desejo ser do sexo oposto ou não. Assim, exigiu-se que o Estado reconhecesse o Grupo Gay da Bahia e o Grupo Triângulo Rosa (RJ) ${ }^{4}$ como agremiações declara-

4 Depois de muito esforço e persistência, perante recusas iniciais, o Grupo Gay da Bahia conseguiu ter seus estatutos registrados. Em 24 janeiro de 1983 o Juiz Gudesten Soares, do fórum Rui Barbosa, de Salvador, deu a sentença favorável ao GGB, em que afirmava: "O homossexualismo é o fato da natureza e não conduta perniciosa, e jamais o seu direito de 


\section{damente homossexuais. Também se conseguiu o reconhecimento da homossexualidade como expressão sexual legítima ${ }^{5}$ e a revogação de}

ser foi definido pelo Legislador Brasileiro como crime ou coisa que o valha. O preconceito e a discriminação, sim, tiveram sempre a repressão da lei maior. Por isso, há de ser o pedido de registro dos estatutos do GGB deferido, como o defiro, mesmo que pareça estranho a quem pudesse negar lugar no Jardim da Criação de Deus, às rosas rubras, brancas e amarelas só porque não são róseas. Registrem-se os estatutos". (Boletim do GGB, mar. 1983)

Valendo-se desse precedente, o Grupo Triângulo Rosa, grupo homossexual carioca, também conseguiu seu registro em 8 de abril de 1985

5 Durante quatro anos, diversas das mais importantes associações cientificas do Brasil aprovaram moções e resoluções apoiando a luta dos "gays" e opondo-se â discriminação e preconceito («homofobia») que pesam contra esta minoria sexual. Eis algumas:

"A Presidência e a Assembleia Geral da SBPC apoiam oficialmente a campanha contra todas as expressões de discriminação sexual; opõem-se energicamente a todas as leis, códigos e posturas que contrariamente â Ciência, rotulam o homossexualismo como 'patologia', resolve que, em suas próximas reuniões anuais, haverá sempre espaço para debates interdisciplinares sobre a questão homossexual; compromete-se a apoiar o encaminhamento do abaixo-assinado contra a discriminação sexual junto aos órgãos governamentais competentes". (MOÇÃO DA SOCIEDADE BRASILEIRA PARA O PROGRESSO DA CIÊNCIA, Salvador 14 jul. 1981)

Considerando que todas as expressões sexuais, desde que respeitem a liberdade alheia, são igualmente válidas e legitimas; que a discriminação sofrida por expressões sexuais consideradas desviantes atropela o direito de todo ser humano de fazer sexo como e com quem quiser. Resolve: apoiar o direito dos movimentos das minorias sexuais de se organizarem e serem respeitados da mesma forma que os demais grupos minoritários; apoiar a campanha nacional de repúdio ao Código 302. O da classificação internacional de doenças, da OMS, que rotula o homossexualismo como desvio e transtorno sexual". (MOÇÃO DA SOCIEDADE BRASILEIRA DE ANTROPOLOGIA, São Paulo, 6 abr. 1982)

Considerando a pequena produção científica no Brasil de pesquisas e trabalhos relativos à sexualidade humana em geral e à homossexualidade em particular; que os projetos de pesquisas sobre esses temas têm sido mal recebidos, discriminados e considerados irrelevantes ou faltos de interesse científico e relevância social. Resolve: usar todo o empenho, através de ofícios às fundações, instituições de pesquisa e órgãos financiadores para que sejam acolhidos com idêntica objetividade e sem discriminação os projetos que tratem de temas relacionados à sexualidade e à homossexualidade, instituindo-se prêmios e estímulos aos projetos sobre esses temas". (MOÇÃO DA SOCIEDADE BRASILEIRA PARA O PROGRESSO DA CIÊNCIA, Campinas, SP, 12 jul. 1982)

Declara-se contra todas as expressões de preconceitos e discriminação de que são alvos os homossexuais de ambos os sexos em nossa sociedade; apoia a campanha nacional de repúdio ao Código 302.0 da CID da OMS, adotado pelo Governo Brasileiro, que de maneira anticientífica rotula a homossexualidade como desvio e transtorno sexual". (MOÇÃO DA ASSOCIAÇÃO BRASILEIRA DE ESTUDOS POPULACIONAIS, Vitória 14 out. 1982)

Considerando a odiosa e violenta discriminação de que são alvo os homossexuais de ambos os sexos em nossa sociedade. Resolve: opor-se a todas expressões de preconceito e discriminação contra os homossexuais; apoiar a campanha contra 0 código 302.0! incentivar junto aos Centros de Pós-Graduação uma maior produção intelectual na área 
sua classificação como "desvio e transtorno sexual" no código de doenças do INAMPS. ${ }^{6}$ Até a maneira como a imprensa retrata a homossexualidade pode vir a se alterar, se o seu código de ética for seguido. Em 1986, graças à iniciativa do veterano militante do Somos e um dos fundadores do Outra Coisa, o jornalista Antonio Carlos Tosta, foi alterado o artigo 19 daquele código que, na sua letra d, passou a incluir entre os atos vedados aos jornalistas: "Concordar com a prática de perseguição ou discriminação por motivos sociais, políticos, religiosos, raciais, de sexo e de orientação sexual". Esta conquista poderia marcar uma importante vitória para o movimento homossexual no Brasil, que, como já vimos anteriormente, fez sua primeira manifestação pública ao protestar contra a maneira preconceituosa pela qual a imprensa retratava os homossexuais. Infelizmente esse código de ética é frequentemente

da sexualidade e da homossexualidade". (MOÇÃO DA ASSOCIAÇÃO NACIONAL DE PÓS- GRADUAÇÃO EM CIÊNCIAS SOCIAIS, São Pedro, SP, 24 out. 1984)

Considerando que a homossexualidade em si não implica em prejuizo ao raciocínio, estabilidade, confiabilidade ou aptidões sociais ou vocacionais, a ABP e suas filiadas se opõem a toda discriminação e preconceitos, tanto no setor público quanto no privado, contra os homossexuais de ambos os sexos". A "Campanha Nacional contra 0 código 302.0" iniciada em 1981 pelo Grupo Gay da Bahia obteve a adesão, além dessas sociedades cientificas, de mais de 16 mil assinaturas, entre outros, 358 políticos (Ulysses Guimarães, Franco Montoro, Fernando Henrique Cardoso, etc.). Moções de apoio à luta dos gays foram aprovados pelas Assembleias Legislativas de Porto Alegre, Florianópolis, São Paulo, Pompéia, Salvador, Maceió e Olinda. (MOÇÃO DA ASSOCIAÇÃO BRASILEIRA DE PSIQUIATRIA, Recife 13 out. 1984)

6 Em fevereiro de 1985 o Conselho Federal de Medicina aprovou o parecer do conselheiro Ivan de Araújo Moura Fé, o qual, em resumo, diz:

Enquanto estiver em vigor a CID (9o Revisão) os casos cujo motivo de atendimento médico for a homossexualidade devem ser codificados na categoria V62: "Outras Circunstâncias Psicossociais".

Quando o comportamento homossexual for condicionado patologicamente, o enquadramento do diagnóstico deve ser feito pela condição nosológica básica.

A categoria V62 abrange as seguintes circunstâncias psicossociais:

- Desemprego;

- Efeitos adversos do ambiente de trabalho;

- Outras circunstâncias ou desajustes ocupacionais;

- Circunstâncias educacionais;

- Desajustamento social;

- Circunstâncias legais;

- Recusa de tratamento por razões religiosas ou de consciência;

- $\quad$ Outras tensões psicológicas ou físicas não classificadas em outra parte;

- Não especificadas

(por essa informação agradeço a João Antonio Mascarenhas) 
desrespeitado, e os interesses materiais dos donos dos jornais têm, como regra, prevalecido sobre as organizações de seus empregados. O ideal, porém, foi registrado e talvez, num futuro ainda imprevisível, venha a exercer um controle real sobre o que se publica.

Menos bem sucedida, mas significativa de uma mudança de atitudes por parte de importantes segmentos da população, foi a efêmera vitória conquistada pelo grupo carioca Triângulo Rosa e seu incansável vice-presidente João Antônio Mascarenhas. Graças a seus esforços e persistência, o primeiro Projeto de Constituinte, elaborado pela Comissão de Sistematização em julho de 1987, incluiu o termo "orientação sexual" entre as razões pelas quais ninguém pode ser privilegiado ou prejudicado $^{7}$. Entretanto, na sua versão final, o termo voltou a ser retirado.

Dizem que, enquanto movimentos como as Comunidades Eclesiais de Base ou as associações de moradores exercem influências a partir do número de seus participantes, outros com número menor de apoiadores, como o movimento feminista -e o homossexual também pode ser incluído aqui - influenciam a vida política e social através de recursos de elite, como os partidos políticos, os meios de comunicação e as instituições culturais. (VIOLA; MAINWARING, 1987, p. 140) Hoje já se generaliza no Brasil a discussão da homossexualidade, a partir de uma compreensão mais informada e menos preconceituosa. Mas, em um dado momento, a divulgação de novas atitudes e práticas foi imensamente facilitada pela existência de indivíduos ou organizações dispostas a enunciá-las. Sem estes interlocutores, que serviram como catalizadores das novas tendências, a imprensa, por exemplo, teria tido muito mais dificuldade em lidar de forma positiva com a questão homossexual. Igualmente, na universidade, aonde o assunto vem atraindo muito interesse, a nova abordagem social foi

7 De acordo com o projeto de Constituição apresentado pela Comissão de Sistematização da Assembleia Constituinte e publicado pelo Centro Gráfico do Senado Federal, assim rezaria o Segundo Título, Capítulo Primeiro, artigo 12, parágrafo segundo, letra J: "ressalva a compensação para igualar as oportunidades de acesso aos valores da vida e para reparar injustiças produzidas por discriminação não evitadas, ninguém será privilegiado ou prejudicado em razão de nascimento, etnia, raça, cor, idade, sexo, orientação sexual, estado civil, natureza do trabalho, religião, convicções políticas ou filosóficas, deficiências física ou mental, ou qualquer outra condição social ou individual". 
fortemente legitimada pela inclusão da luta homossexual no tópico dos movimentos sociais urbanos e pelas numerosas intervenções, palestras e debates promovidos por artistas homossexuais.

Vimos que, apesar de congregar um segmento minoritário, cujas aspirações e modo de vida têm sofrido severa estigmatização por quase todos os setores da sociedade, o Somos se mostrou muito semelhante, em sua organização e desenvolvimento, a inúmeros outros movimentos sociais voltados à promoção de mudanças políticas. Assim, como eles, o Somos também apresentava importantes deficiências: um reduzido número de militantes e um despreparo generalizado para a atuação política, especialmente num nível mais geral, menos relacionado a suas reivindicações específicas. A ditadura favorecia um simplismo maniqueísta, no qual as forças políticas podiam ser divididas entre Sistema e Oposição, mas a implantação gradual de uma nova ordem civil e mais pluralista trouxe novas dificuldades para todos esses movimentos. A reorganização do sistema partidário desempenhou um considerável papel divisionista, atuando em níveis inter e intragrupais. O próprio Estado também vem sofisticando sua atuação, aumentando assim o seu poder de cooptação junto aos setores que formaram a base desses movimentos. Estes, embora incapazes de transformar, por si sós, o Brasil numa sociedade democrática , não devem ter menosprezada a sua importância na dinâmica cultural da atualidade, especialmente no tocante à renovação que vêm promovendo nos valores que estão na base das ideologias, discursos e práticas políticas.

Por sua vez, o Somos, assim como outras manifestações do Movimento Homossexual Brasileiro, encontrou suas maiores dificuldades e desafios justamente devido à sua pretensão de construir uma sociedade mais igualitária, ao mesmo tempo em que procura alargar os limites à tolerância da diversidade, atuando especialmente no sentido de promover o questionamento das noções recebidas sobre a sexualidade e o papel social atribuído aos homens e às mulheres. Enfatizando o lúdico e o inconformismo, questionou a naturalidade das relações sociais e celebrou a soberania do indivíduo, promovendo o libertarianismo, tanto explicitamente, através de suas reivindicações, quanto implicitamente, nos seus ideais de organização não hierárquica. 


\section{Epílogo}

Talvez, ao chegar aqui, o leitor queira perguntar por que este trabalho é tão longo e detalhista. Em resposta, eu chamaria a atenção para a complexidade da tarefa a que me propus, procurando, por um lado, entender as transformações que ocorrem na construção social da homossexualidade no Brasil e, por outro, lidar com um movimento social inserido em uma conjuntura política. Além do mais, se procurou simultaneamente fazer uma pesquisa e analisar uma vivência, o que não é fácil.

Relendo este trabalho, já pronto, fico um pouco perturbado com a imagem negativa, do Somos e da militância homossexual em geral, que ele pode acabar transmitindo. Receio que isso seja quase inevitável, quando se procura deixar de lado o que é dito, enfatizando o que de fato ocorre e as várias relações estabelecidas entre o grupo que é objeto da pesquisa e as outras forças socialmente atuantes.

Quanto mais elevados os ideais apregoados por uma organização, mais fácil se torna fazê-la parecer hipócrita. Quando, como aqui, se procura entender relações de dominação e manipulação dentro de um grupo que se diz dedicado ao combate ao poder, inevitavelmente essa é uma consequência. Mas desejo deixar claro que, ao procurar, como antropólogo, "desvendar as máscaras sociais" não estou procurando "desmascarar" os militantes. 
A atuação política é necessariamente diversa da pesquisa antropológica e geralmente requer a formulação de utopias que sirvam como pontos de referência para as tentativas de efetuar mudanças na realidade existente. Submetidos a um crivo rigoroso, científico e antropológico, é provável que nenhuma das instituições mais respeitáveis se mostrassem totalmente coerentes com seus ideais, pensemos, por exemplo, nas igrejas, nos partidos políticos ou na própria universidade. Expostos os seus mecanismos internos, todos podem ser pintados com cores sombrias. Mas, desejar simplesmente erradicá-las seria talvez o equivalente a querer a abolição da realidade e não a sua transformação.

Os ideais da luta contra o poder e contra a dominação de um ser humano por outro são profundamente significativos num momento como o atual, quando o processo do controle das mentes e dos corpos é promovido através de métodos que ora empregam a maior sutileza, ora a violência mais brutal. Foucault já nos mostrou que não se pode pular fora das malhas do poder, mas, dada a polivalência tática dos discursos, creio que, em certas ocasiões, pode-se falar contra o poder, em geral, para atacar algumas de suas configurações específicas.

Não há dúvida de que, em nossa sociedade atual, têm sido negado svários dos direitos de cidadania daqueles indivíduos percebidos como sendo homossexuais, usando-se para isso uma enorme variedade de justificativas, que vão desde a saúde e a moral até a segurança nacional. Contra esse estado de coisas, algumas pessoas procuraram reagir, empregando as linguagens correntes em um dado momento histórico. Se não realizaram a sonhada - e, creio, impossível - abolição do "poder", conseguiram de várias maneiras melhorar a sua condição social.

É inegável a eficácia dos grupos homossexuais em vários sentidos. Talvez, a principal tenha sido a construção de redes de sociabilidade, unindo - e também promovendo - um novo tipo de homossexual que não é dominado por sentimento de culpa e não se considera doente ou anormal. Mesmo depois de cessadas as atividades declaradamente militantes, essas redes têm sobrevivido e, em muitos casos, têm sido cruciais na história de vida de muitos de seus participantes, influindo na sua escolha de moradia, de emprego, de atividades de lazer e de opção política. 
Atualmente, com o trágico surto da Síndrome da Imunodeficiência Adquirida (aids), que vem vitimando principalmente homossexuais, tem sido notada a importância dessas redes e da adoção de uma identidade homossexual para uma melhor gestão da crise. Como diz Michael Pollak ao comentar a situação na França: “A solidão de um homossexual perante a moléstia é tanto maior quando ele havia assumido mal a sua homossexualidade e consequentemente não havia conseguido construir laços de amizades estáveis e duráveis à sua volta”. (POLLAK; SCHILTZ, 1987, p. 100)

Do ponto de vista político e social, a atuação dos militantes homossexuais serviu também para tornar a homossexualidade mais "respeitável" ou legítima e hoje muitas autoridades políticas, médicas ou acadêmicas, sentem-se seguras em fazer declarações de apoio ao estilo de vida homossexual sem maiores constrangimentos. Isso adquire uma importância crucial com o advento da aids, quando, apesar da persistência generalizada de preconceitos anti-homossexuais entre médicos e outros profissionais da saúde, os programas oficiais têm sido obrigados a reconhecer a legitimidade social do comportamento homossexual e a necessidade de se respeitar os direitos de cidadania dos seus praticantes.

São Paulo, setembro de 1989. 


\section{Referências}

ALMEIDA, P. da. Homossexualismo: a libertinagem no Rio de Janeiro. Rio de Janeiro: Laemmert, 1906.

ALMEIDA, S. J. A. Michês. 1984. 220 f. Dissertação (Mestrado em Psicologia Social) - Pontificia Universidade Católica de São Paulo, 1984.

ALTMAN, D. AIDS and the newpuritanism. London: Pluto Press, 1986.

BATISTA, N. A penalização do prazer. In: MACIEL, L. C.; SABINA, M. (Org.). Maconha em debate. São Paulo: Brasiliense, 1985. p. 107-117.

BELL, A. P.; WEINBERG, M. S. Homosexualities: a study of diversity among men and women. New York: Simon and Schuster, 1979.

BERNARDET, J. C. Os homossexuais no momento de sua definição. Folha de S. Paulo, São Paulo, jul. 1982. Folhetim, Suplemento. p. 9.

BISORDI, G. Adeus à medieval, até dezembro. Folha de S. Paulo, São Paulo, 1984. p. 49.

BOSWELL, J. Towards the long revolutions, universais and sexual categories. Salmagund, New York, n. 58-59, p. 89-113, 1982.

BRAY, A. Homosexuality in renaissance England. Londres: Gay Men’s Press, 1982.

CARDOSO, R. Movimentos sociais urbanos: balanço crítico. In: SORJ, B.;

ALMEIDA, M. H. T. de. (Org.). Sociedade e política no Brasil pós - 64. São Paulo: Brasiliense, 1983. p. 213-239.

CASTELLO BRANCO, L. O que é erotismo. São Paulo: Brasiliense, 1984.

CASTORIADIS, C.; COHN BENDIT, D. Da ecologia à Autonomia. São Paulo: Brasiliense, 1981. 
CLASTRES, P. A sociedade contra o Estado: pesquisas de antropologia política. Rio de Janeiro: Livraria Francisco Alves, 1982.

COELHO, C. N. P. Nas pegadas do sucesso: uma introdução à análise das memórias da guerrilha e do exílio. São Paulo: Ed. UNICAMP, 1984.

CORRÊA, M. Antropologia e medicina legal: variações em torno de um mito. In: EULÁlIO, A. (Org.). Caminhos cruzados: linguagem antropológica e ciências naturais. São Paulo: Brasiliense, 1982. p. 33-52.

CRUZ, R. Os novos movimentos sociais: encontros e desencontros com a democracia. In: SCHERER-WARREN, I.; KRISCHKE, P. J. (Org.). Uma revolução no cotidiano? Os novos movimentos sociais na América Latina. São Paulo: Brasiliense, 1987. p. 86-101.

CRUZ, S. C. V.; MARTINS, C. E. De Castello a Figueiredo: uma incursão na pré-história da "abertura". In: SORJ, B.; ALMEIDA, M. H. T. de. (Org.). Sociedade política no Brasil pós - 64. São Paulo: Brasiliense, 1983. p. 215-239.

CUNHA, M. C. da. Antropologia do Brasil. São Paulo: Brasiliense, 1986.

D’EMÍLIO, J. Sexual politics, sexual comunities. Chicago: The University of Chicago Press, 1983.

DAMATTA, R. Para uma teoria da sacanagem: uma reflexão sobre a obra de Carlos Zéfiro. In: MATTA, R. da; MARINHO, J. (Org.). A arte sacana de Carlos Zéfiro: 7 histórias completas de Carlos Zéfiro. Rio de Janeiro: Distribuidora Record de Serviços de Imprensa, 1983. p. 208.

DOVER, K. J. Greek homosexuality. New York: Vintage Books, 1980.

DUMONT, L. Homo hierarchicus. Londres: Paladin, 1972.

DURHAM, E. Antropologia hoje: problemas e perspectivas. In: ASSOCIAÇÃO NACIONAL DE PÓS - GRADUAÇÃ̃ E PESQUISA EM CIÊNCIAS SOCIAIS, 7., 1983, Águas de São Pedro, SP. Anais...Águas de São Pedro, SP, 1983.

DURHAM, E. Movimentos sociais: a construção da cidadania. NOVOS ESTUDOS CEBRAP, São Paulo, n. 10, p. 24 - 30, out. 1984.

DURST, R. Madame Satã. São Paulo: Brasiliense, 1985.

ELLIS, H. Sexual inversion. In: ELLIS, H. Studies in the psychology of sex. New York: Random House, 1936.

EMEDIATO, L. F. Geração abandonada. São Paulo: Global, 1982.

EULÁliO, A. As ilusões da liberdade. 1982. Tese (Doutorado em Ciência Sociais) - Faculdade de Filosofia e Ciências Humanas, Universidade de São Paulo, São Paulo, 1982.

EVANS-PRITCHARD, E. Sexual inversion among the Azande. American Anthropologist, Washington, v. 72, n. 6, p. 1428-1434, 1970.

EVERS, T. De costas para o Estado, longe do parlamento. NOVOS ESTUDOS CEBRAP, v. 2, n. 1, p. 25-39, abr. 1983.

EVENS, T. Identidade, a face oculta dos novos movimentos sociais. NOVOS ESTUDOS-CEBRAP, v. 2, p. 11-23, abr. 1984. 
FARADAY, A. Liberating Lesbian Research. In: PLUMMER, K. The making of the modern homosexual. Londres: Hutchinson and Co., 1981.

FÉRAY, J. C. Une histoire critique du mot homosexuality. Culture and Questions Qui Font Debats, Paris, n. 325, jan. 1981.

FORD, C. S.; BEACH, F. A. Patterns of sexual Behavior. New York: Harper and Row, [1950].

FOUCAULT, M. Eu, Pierre Riviére, que degolei minha mãe, minha irmã e meu irmão. 8. ed. Rio de Janeiro: Graal, 1977.

FOUCAULT, M. História da sexualidade I: a vontade de saber. 2. ed. Rio de Janeiro: Graal, 1979.

FOUCAULT, M. An Interview. Sex, Power and the politics of identity. The Advocate, San Mateo, n. 400, p. 26, ago. 1984.

FRANCHETTO, B.; CAVALCANTI, M. L. V. de C.; HEILBORN, M. L. Antropologia e feminismo. In: FRANCHETTO, B.; CAVALCANTI, M. L. V. de C.; HEILBORN, M. L. Perspectivas antropológicas da mulher. Rio de Janeiro: Zahar, 1981. p. 11- 48.

FREUD, S. Three Essays on the theory of sexuality. In: FREUD, S. et al. Pelican Freud Library. Harmondsworth: Penguin Books, [19-]. v. 7.

FRY, P. Da hierarquia à igualdade: a construção da homossexualidade no Brasil. In: FRY, P. Para inglês ver: identidade e política na cultura brasileira. Rio de Janeiro: Zahar, 1982. p. 87-115.

FRY, P. Febrónio Índio do Brasil: onde cruzam a psiquiatria, a profecia, a homossexualidade e a lei. In: EULÁLIO, A. Caminhos cruzados: linguagem, antropologia e ciências naturais. São Paulo: Brasiliense, 1982. p. 65-80.

FRY, P. História da Imprensa Baiana. Lampião, Rio de Janeiro, n. 4, ago. 1978.

FRY, P. Homossexualidade masculina e cultos afro-brasileiros. In: FRY, P. Para inglês ver: identidade e política na cultura brasileira. Rio de Janeiro: Zahar, 1982. p. 54-86.

FRY, P. Ser ou não ser homossexual, eis a questão. Folha de S. Paulo, São Paulo, jan. 1982. Folhetim, n. 3.

GAJARDO, M. Pesquisa participante na América Latina. São Paulo: Brasiliense, 1986.

GALLAGHER, B.; WILSON, A. Michel Foucault, an interview: sex, power and the politics of identity. The Advocate, San Mateo, n. 400, p. 26 - 30, aug. 1984.

GOFFMAN, E. Stigma: notes on the management of spoiled identity. Londres: Penguin Books, 1968.

GONZALES, L. O movimento negro na última década. In: GONZALES, L.;

HASENBALG, C. H. Lugar de negro. Rio de Janeiro: Marco Zero, 1982. p. 9-68. (Dois Pontos, v. 3).

GREEN, J. N.; QUINALHA, R. (Org.). Ditadura e homossexualidades: repressão, resistência e a busca da verdade. São Carlos, SP: EdUFSCar, 2014.

GREEN, J.; TRINDADE, R. (Org.). Homossexualismo em São Paulo e outros escritos. São Paulo: Ed. UNESP, 2005. 
GUATTARI, F. Revolução molecular: pulsações políticas do desejo. São Paulo: Brasiliense, 1981.

GUIMARÃES, C. D. O homossexual visto por entendidos. 1977. 154 f. Dissertação (Mestrado em Antropologia Social) - Museu Nacional, Universidade Federal do Rio de |Janeiro, Rio de Janeiro, 1977.

HART, J.; RICHARDSON, D. Perspectivas teóricas sobre a homossexual idade. In: HART, J.; RICHARDSON, D. Teoria e prática da homossexualidade. Rio de Janeiro: Zahar, 1983. p. 15-50.

HOCQUENGHEM, G. A contestação homossexual. São Paulo: Brasiliense, 1980. HOCQUENGHEM, G. Homosexual desire. Londres: Allison \& Busby, 1978.

HOCQUENGHEM, G. Race d'ep! Um siécle d'lmages de l'homosexualité. Paris: Hallier, 1979.

HOLANDA, H. B. Impressões de viagem: CPC, vanguarda e desbunde. São Paulo: Brasiliense, 1980.

HOOKER, E. Homossexuais masculinos e seus mundos. In: MARMOR, J. (Org.). A inversão sexual. Rio de Janeiro: Imago, 1973. p. 77-95.

HOOKER, E. The adjustment of the male ovart homossexual. Journal of Projective Techniques, v. 21, n. 1, p. 18-31, mar. 1957.

HUTCHINSON, H. W. Village and plantation life in north eastern Brazil. Seattle: University of whashington Press, 1957.

KATZ, J. Gay American history: lesbians and gay men in the USA: a documentary history. New York: Avon Books, 1976.

KINSEY, A. C. Sexual Behaviour in the Human Male. Philadelphia: Saunder, 1948.

KINSEY, A. C.; POMEROY, W. B.; MARTIN, C. E. O comportamento sexual do homem. Tradução Augusto Coutinho Lage e Paulo Duarte Miranda. Lisboa: Meridiana, 1972.

KROEBER, A. L. Psychosis or social Saction. In: KROEBER, A. L. The nature of culture. Chicago: The University of Chicago Press, 1952.

KUCINSKI, B. Abertura, a história de uma crise. São- Paulo: Debates, 1979.

LAURISTEN, J.; THORSTAD, D. The early homosexual rights movement (18641935). New York: Time Change Press, 1974.

LÉVI-STRAUSS, C. Tristes trópicos. Lisboa: Martins Fontes, 1955.

LOBERT, R. A palavra mágica Dzi: uma resposta difícil de perguntar. 1979. 250

f. Dissertação (Mestrado em Antropologia Social) - Instituto de Filosofia e Ciências Humanas, Universidade Estadual de campinas, São Paulo, 1979.

MACEDO, C. C. Tempo de Génesis: o povo das comunidades eclesiais de base. São Paulo: Brasiliense, 1986.

MACHADO, K. Danação da norma: medicina social e constituição da psiquiatria no Brasil. São Paulo: Graal, 1978.

MACRAE, E. A construção da igualdade: identidade sexual e política no Brasil da "abertura". Campinas, SP: Ed. UNICAMP, 1990. 
MACRAE, E. Afirmação de identidade homossexual: seus perigos e sua importância. In: TRONCA, Í. A. (Org.). Foucault vivo. Campinas, SP: Pontes, 1987a. p. 81-88.

MACRAE, E. AIDS: prevenção ou nevo tipo de segregacionismo? Tema IMESC Sociedade, Direito e Saúde, São Paulo, v. 4, n. 1, p. 73-81, 1987b.

MACRAE, E. Em defesa do gueto. NOVOS ESTUDOS - CEBRAP, São Paulo, v. 2, n. 1, p. 53-60, abr. 1983.

MACRAE, E. O Militante Homossexual no Brasil da Abertura. 1985. 218 f. Tese (Doutorado em antropologia) - Faculdade de Filosofia, Letras e Ciências Humanas, Universidade de São Paulo, São Paulo, 1985.

MACRAE, E. Os respeitáveis militantes e as bichas loucas. In: EULALIO, A. et al. (Org.). Caminhos Cruzados. São Paulo: Brasiliense, 1982. p. 99-111.

MARMOR, J. A inversão sexual. Rio de Janeiro: Imago, 1973.

MARX, K.; ENGELS, F. A ideologia alemã. São Paulo: Ed. Ciências Humanas, 1979.

MATTOSO, G. Manual do pedólatra amador: aventuras \& leituras de um tarado por pês.. São Paulo: Expressão, 1986.

MCINTOSH, M. Postcript: the homosexual role revisited. In: PLUMMER, K. The making of the modern homosexual. Londres: Hutchinson, 1981.

MCINTOSH, M. The homosexual role. Society for the study of Social Problems, Estados Unidos, v. 16, n. 2, p. 182-192, 1968.

MCPHERSON, C. B. A teoria política do individualismo possessivo, de Hobbes até Locke. 3. ed. Rio de Janeiro: Paz e Terra, 1979.

MEDEIROS, P. T. C. A Aventura da Jovem Guarda. São Paulo: Brasiliense, 1984.

MÍCOLIS, L. "Snob", "Le Femme” ... Os bons tempos da imprensa gay. Lampião, Rio de Janeiro, ano 3, n. 28, p. 6-7, set. 1980.

MÍCOLIS, L.; DANIEL, H. Jacarés e Lobisomens: dois ensaios sobre a homossexualidade. Rio de Janeiro: Achiamé, 1983.

MISSE, M. Sociologia e criminalização. In: MACIEL, L. C.; SABINA, M. (Org.). Maconha em debate. São Paulo: Brasiliense, 1985. p. 49-62.

MORAES, M. L. Q. Família e Feminismo: reflexões sobre papéis femininos na imprensa para mulheres. 1981. 329 f. Tese (Doutorado em Ciências Políticas) Faculdade de Filosofia, Letras e Ciências Humanas, Universidade de São Paulo, São Paulo, 1981.

MOTT, L. R. F. Dez viados em questão: tipologia das homossexuais da cidade de Salvador, Bahia. In: ASSOCIAÇÃO BRASILEIRA DE ANTROPOLOGIA, 13 1987, Salvador. Anais... Salvador: Espaço Blejj, 1987. p. 37.

MOTT, L. R. F.; ASSUNÇÃO, A. Gilete na Carne: etnografia das auto mutilações dos travestis da Bahia. Temas IMESC - Sociedade, Direito e Saúde, São Paulo, v. 4, n. 1, 1987.

OLIVEIRA, R. C. Identidade, Etnia e Estrutura Social. São Paulo: Pioneira, 1976.

OSWALDO JUNIOR. A luta pela descriminalização. In: MACIEL, L. C.; SABINA, M. (Org.). Maconha em debate. São Paulo: Brasiliense, 1985. p. 129-133. 
PADGUG, R. A. Sexual matters: on conceptualizing sexuality in history. Radical History Review, New York, v. 20, p. 3 - 23, 1979.

(A) PALAVRA é viado - entrevista com Aguinaldo Silva. Pasquim, Rio de Janeiro, n. 636, 1981.

PERLONGHER, N. O negócio do michê: prostituição viril em São Paulo. 1. ed. São Paulo: Brasiliense, 1987.

PERLONGHER, N. Transformações no espaço urbano: o gueto gay paulista desde 1959. ASSOCIAÇÃO NACIONAL PÓS-GRADUAÇÃO E PESQUISA EM CIÊNCIAS SOCIAIS, 8., 1984, Água de São Pedro, SP. Anais... Água de São Pedro, SP, 1984.

PLUCIENNIK, T. I. O psicodrama e uma minoria social: avaliação inicial de uma experiência com homossexuais. São Paulo: Comissão de Ensino da Sociedade de Psicodrama de São Paulo, 1981.

POLLAK, M.; SCHILTZ, M. A. Identité sociale et gestión d'un risque de santé: les homosexuels face au SIDA. Actes de la recherche en sciences sociales, Paris, p. 77-102, jun. 1987.

PONTES, H. A. Do palco aos bastidores: o SOS mulher (SP) e as práticas feministas contemporâneas. 1986. 274f. Dissertação (Mestrado em Antropologia Social) - Universidade Estadual de Campinas, Campinas, SP, 1986.

RAMALHO, J. R. O mundo do crime: a ordem pelo avesso. Rio de Janeiro: Graal, 1979.

RICHARDSON, D. Perspectivas teóricas sobre a homossexualidade. In: RICHARDSON, D.'HART, J. Teoria e prática da homossexualidade. Rio de Janeiro: Zahar, 1983. p. 15-50.

SANTOS, W. A participação dos homossexuais no movimento negro brasileiro. Salvador: [Adé Dudu?], 1984.

SCHERER-WARREN, I. O caráter dos novos movimentos sociais. In: SCHERERWARREN, I.; KRISCHKE, P. J. (Org.). Uma revolução no cotidiano? Os novos movimentos sociais na América Latina. São Paulo: Brasiliense, 1987. p. 35-53.

SILVA, B. Aspectos sociológicos do homossexualismo em São Paulo. Sociologia, v. XXI, n. 4, out. 1959.

SILVA, J. E. B. da. Aspectos sociológicos do homossexualismo em São Paulo. Sociologia, v. 21, n. 4, p. 350-360, out. 1959.

SILVA, L. L. AIDS e a homossexualidade em São Paulo. 1986. 204f. Dissertação (Mestrado em Antropologia) - Pontifícia Universidade Católica de São Paulo, São Paulo, 1986.

SINGER, P. Movimentos sociais em São Paulo: traços comuns e perspectivas. In: SINGER, P.; BRANT, V. C. (Org.). São Paulo: o novo em movimento. Petrópolis, RJ: Vozes, 1983. p. 207-230.

SINGER, P. O feminino e o feminismo. In: SINGER, P.; BRANT, V. C. (Org.). São Paulo: o novo em movimento. Petrópolis, RJ: Vozes, 1983. p. 109-141.

SONTAG, T. S. Notes on Camp. In: SONTAG, T. S. Against interpretation: and other essavs. New York: Dell Publishing, 1966. p. 275-292. 
SZASZ, T. S. The myth of mental illness: foundations of a theory of personal conduct. New York: Harper \& Row, 1974.

TAX, S. Action Anthropology. In: CLAESSEN, H. J. M.; SKALNÍK, P. Current Anthropology in the netherlands. Chicago: University of Chicago Press, 1975. p. 514-517.

TELLES, V. S. Movimentos sociais: reflexões sobre a experiência dos anos 70. In: SCHERER-WARREN, I.; KRISCHKE, P. J. (Org.). Uma revolução no cotidiano? Os novos movimentos sociais na América Latina. São Paulo: Brasiliense, 1987. p. 4-85.

TREVISAN, J. S. Devassos no paraíso. [São Paulo]: Max Limonad, 1986.

TREVISAN, J. S. Encontros e brigas de vários graus. Lampião, p. 5, maio 1980.

TURNER, V. The ritual process: structure and anti-structure. Londres: Pelican, 1974.

VELHO, G. O consumo de cannabis e suas representações culturais. In:

MACIEL, L. C.; SABINA, M. (Org.). Maconha em debate. São Paulo: Brasiliense, 1985. p. 39-47.

VIOLA, E.; MAINWARING. Novos movimentos sociais: cultura, política e democracia Brasil e Argentina. In: SCHERER-WARREN, I.; KRISCHKE, P. J. (Org.). Uma revolução no cotidiano? Os novos movimentos sociais na América Latina. São Paulo: Brasiliense, 1987. p. 102-188.

WEEKS, J. Coming out: homosexual politics in Britain, from the nineteenth century to the present. Londres: Quartet Books, 1977.

WEEKS, J. Discourse, desire and sexual deviance. Some problems in a history of homosexuality. In: PLUMMER, K. The making of the modem homosexual. 1. ed. Londres: Hutchinson, 1981. p. 76-111.

WEEKS, J. Sex, politics and society. The regulation of sexuality since 1800. Londres: Longman, 1981.

WEEKS, J. Sexuality and its discontents: meanings myths and modern sexuality. London: Routledge and Kegan Paul, 1985.

WEEKS, J. Sexuality. London: Tavistock, 1986.

WHITSHEAD, H.; ORTNER, S. B. The bow and the burden strap: a new look at institutionalized homosexuality in native North America. In: ORTNER, S. B.; WHITEHEAD, H. Sexual meanings, the cultural construction of gender and sexuality. Cambridge: Cambridge University Press, 1981. p. 80-115.

ZALUAR, A. A máquina e a revolta: as organizações populares e o significado da pobreza. Tese (Doutorado em Antropologia) - Faculdade de Filosofia, Letras e Ciências Humanas, Universidade de São Paulo, 1983.

ZUCHA, J. V. O papel catalizador do jornal Lampião da esquina no movimento brasileiro de libertação homossexual. São Paulo: PUC/SP, 1980. 


\footnotetext{
— ste livro foi produzido em formato 170 x $240 \mathrm{~mm}$ e utiliza

Es tipografias TT Tricks e Museo Sans Rounded, com miolo em papel Alta Alvura $75 \mathrm{~g} / \mathrm{m}^{2}$ capa em Cartão Supremo $300 \mathrm{~g} / \mathrm{m}^{2}$, impressa na I. Bigraf.

Tiragem: 400 exemplares.
} 